\title{
Archaeological and Historical Investigations at Wallisville Lake, Chambers and Liberty Counties, Texas
}

Anne A. Fox

D. William Day

Lynn Highley

Follow this and additional works at: https://scholarworks.sfasu.edu/ita

Part of the American Material Culture Commons, Archaeological Anthropology Commons, Environmental Studies Commons, Other American Studies Commons, Other Arts and Humanities Commons, Other History of Art, Architecture, and Archaeology Commons, and the United States History Commons

Tell us how this article helped you.

This Article is brought to you for free and open access by the Center for Regional Heritage Research at SFA ScholarWorks. It has been accepted for inclusion in Index of Texas Archaeology: Open Access Gray Literature from the Lone Star State by an authorized editor of SFA ScholarWorks. For more information, please contact cdsscholarworks@sfasu.edu. 


\section{Archaeological and Historical Investigations at Wallisville Lake, Chambers and Liberty Counties, Texas}

Creative Commons License

(c) (1) (9)

This work is licensed under a Creative Commons Attribution-NonCommercial 4.0 International License 
ARCHAEOLOGICAL AND HISTORICAL INVESTIGATIONS

AT WALLISVILLE LAKE, CHAMBERS AND LIBERTY COUNTIES, TEXAS

Anne A. Fox, D. William Day, and Lynn Highley

\author{
Submitted to: \\ U.S. Corps of Engineers \\ Galveston District
}

Center for Archaeological Research The University of Texas at San Antonio Archaeological Survey Report, No. 90 
1. Archaeological survey and testing and historical research in the Wallisville Lake area;

2. Wallisville Lake project;

3. Liberty and Chambers Counties, Texas;

4. Thomas R. Hester, principal investigator; Anne A. Fox, field director and senior author;

5. Galveston District, U.S. Corp of Engineers, Contract No. DACW64-79-C-0042;

6. Published by the Center for Archaeological Research, The University of Texas at San Antonio, San Antonio, Texas 78285; June 1980 . 


\section{ABSTRACT}

During July and August 1979, the Center for Archaeological Research, The University of Texas at San Antonio, conducted survey, testing, and historical research on lands to be included in the Wallisville Lake in Liberty and Chambers Counties, Texas. A summary is presented of 21 previously recorded prehistoric sites within the proposed Plan $2 \mathrm{~A}$, with recommendations for further treatment of these sites. Test excavations at a newly located prehistoric site are described. A detailed description of the history and archaeological testing of 19 historic sites is included, along with a history and description of the town of Wallisville. Artifacts are illustrated and faunal analysis described and tabulated; numerous maps, photographs, and drawings are included. Appendices include a series of early newspaper articles on brick making and a catalog of artifacts recovered from a test pit at a late 19th-century boarding house. 

Page

Abstract ................................

List of Figures .................... v

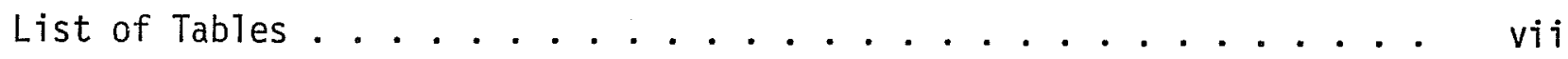

Acknowledgments ................. viij

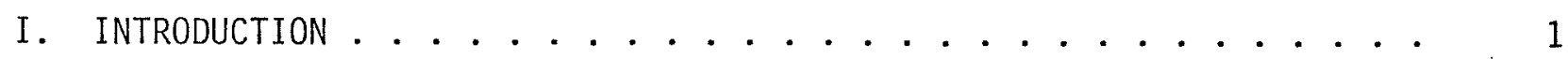

Scope of Work ..................... . . 1

Methodology ............................ 2

Environment ............................. 4

Archaeological Background ............... 5

II. PREHISTORIC SITES INVESTIGATIONS . . . . . . . . . . . . 7

Survey of Control Structures ............. . . 7

Tested Sites . . . . . . . . . . . . . . . 10

Archaeological Investigations, 41 LB 48 . . . . . . . 10

Analysis of Ceramics from All Prehistoric Sites . . . . . . 20

III. HISTORY OF THE WALLISVILLE AREA . . . . . . . . . . . . 37

Introduction ..................... 37

The Indians . . . . . . . . . . . . . . . 39

The Spanish Era................ . . . 39

The Mexican Era................ . . 51

Recent History ....................... 52

IV. HISTORIC SITES INVESTIGATIONS ...................... 53

mcmanus survey: 41 LB 49 , mcmanus landing .......... 53

History of the McManus Survey . . . . . . . . . 53

McManus Landing, 41 LB 49 (01d Fisher P1ace) . . . . . . . 53 

MCFADDIN SURVEY: $41 \mathrm{CH}$ 232, BRICK KILN AND $41 \mathrm{CH} 233$,

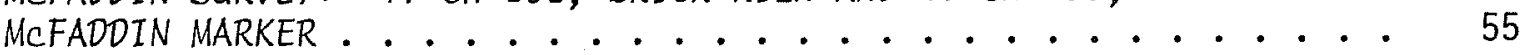

History of the McFaddin Survey . . . . . . . . . 55

Archaeological Investigation of $41 \mathrm{CH} 232$, Brick KiTn . . . 58

McFaddin Marker, $41 \mathrm{CH} 233$............ 63

LABADIE SURVEY: $41 \mathrm{CH}$ 62, LABADIE SITE AND $41 \mathrm{CH} 234$,

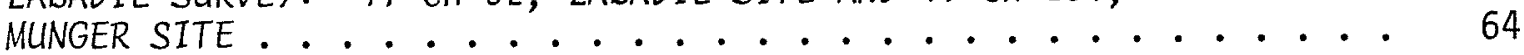

History of the N. D. Labadie Survey ........... 64

Archaeological Investigation, Labadie Site (41 CH 62) . . . 65

Archaeological Investigation, Munger Site (4l CH 234) . . . 82 ORCOQUISAC HISTORIC DISTRICT . . . . . . . . . . . . 82

Presidio San Agustín de Ahumada, $41 \mathrm{CH} 57$. . . . . . 83

Orcoquisac Camp and Prehistoric Site, 41 CH 22 ...... . 93

Mission Nuestra Señora de la Luz (second site), $41 \mathrm{CH} 54$. . 98

Davis Farm Site, $41 \mathrm{CH} 245 \ldots 100$

Presidio San Agustín de Ahumada (second site), $41 \mathrm{CH} 53$. . 102 SHIPWRECK IN LAKE MILLER ............... 103 THE TOWN OF WALLISUILLE ............... 105

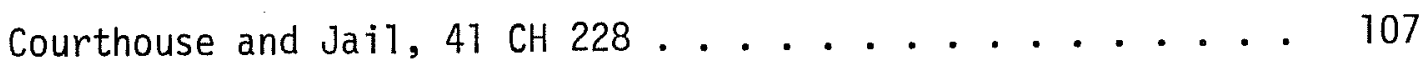

W. B. Gordon House Site, $41 \mathrm{CH} 241$. . . . . . . . 109

T. J. Shelton House Site, $41 \mathrm{CH} 237$......... 109

Block 9......................... 115

Dr. T. W. Shearer House Site, $41 \mathrm{CH} 238$. . . . . 116

H. R. Wallis House Site, $41 \mathrm{CH} 240$.......... 120

Wilson Boarding House, $41 \mathrm{CH} 239 \ldots 123$

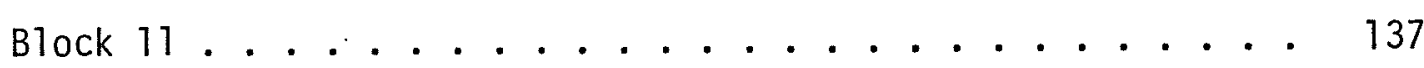

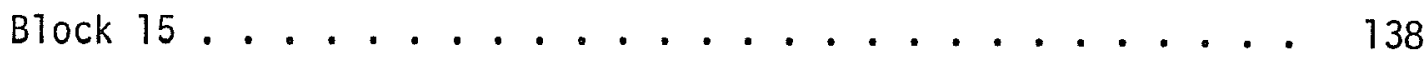



TABLE OF CONTENTS (continued)

Page

Block $16 \ldots \ldots . \ldots \ldots 138$

Conclusions on Wallisville............. 138

Recommendations ............... 140

Future Work ................ . 140

WEST OF THE TRINITY RIVER . . . . . . . . . . . . . . 142

Cummings Lumber Mi11, $41 \mathrm{CH} 243 \ldots \ldots 142$

J. J. Mayes Farm Site, $41 \mathrm{CH} 242$.......... 153

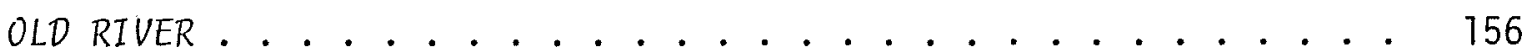

Icet Mill and Boat Yard, $41 \mathrm{CH} 244 \ldots . . . . . . .156$

Almeras Brick Works, $41 \mathrm{CH} 231 \ldots . . . . . . . .157$

The Coffee Site, $41 \mathrm{CH} 103 \ldots . . . . . . . . . . . .2161$

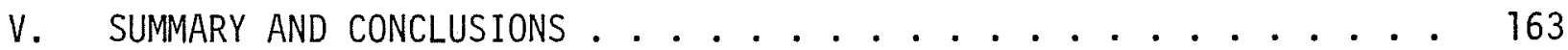

Area of $\mathrm{P} \operatorname{lan} 2 \mathrm{~A} \ldots \ldots . \ldots 163$

Area Outside P1an $2 A \ldots \ldots 165$

References cited ................. 167

Public Records, Chambers and Liberty Counties . . . . . . . . 176

Archival Sources ................ 176

Appendix I. Cedar Bayou Brickyards . . . . . . . . . . . . . 181

Appendix II. Artifacts from Wilson Boarding House Test Pit . . . . 189

Appendix III. "Inventory of the Goods Which the Mission of Nuestra Señora de la Luz has, Existing in the Royal Presidio of San Agustin de Ahumada ..." (Translation by Dora Guerra)................ 



\section{LIST OF FIGURES}

Figure

Page

1. Map of Wallisville Lake Area . . . . . . . . . . . . 8

2. Map of Prehistoric Site 41 LB $48 \ldots 11$

3. Prehistoric Artifacts . . . . . . . . .... 15

4. Ceramic Sequence for Wallisville Reservoir Area ........ 22

5. Key to Ceramic I17ustrations ............... 24

6. Grog-Tempered and Untempered Ceramic Sherds ......... 25

7. Grog-Tempered Ceramic Sherds . . . . . . . . . . . 26

8. Sandy Paste Untempered Ceramic Sherds from Surface of $41 \mathrm{CH} 62$. . 27

9. Sandy Paste Untempered Rim Sherds ... . . . . . . . . . 29

10. Sandy Paste Untempered Ceramic Sherds . . . . . . . . . . 30

11. Sandy Paste Untempered Sherds from 41 LB 48 . . . . . . . . 32

12. Sandy Paste Untempered Sherds from 41 LB 48 . . . . . . . . . . 34

13. Sandy Paste Untempered Sherds from 41 LB 48 . . . . . . . . 35

14. Map Locating Spanish Sites in 18th Century Texas . . . . . . . . 38

15. Map of Wallisville Lake Area ............... 54

16. Artifacts from 41 LB 49 , McManus Landing . . . . . . . . 56

17. Artifacts from McFaddin Grant Sites ............ 60

18. Map of Site $41 \mathrm{CH}$ 232, McManus Brick Kiln ......... 62

19. Map of $41 \mathrm{CH} 62$, Labadie Site ............. 66

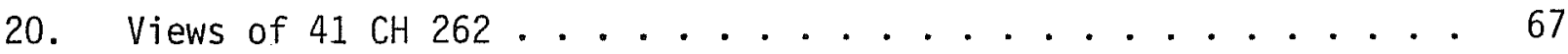

21. Ceramics from $41 \mathrm{CH} 62$, Labadie Site ............ 72

22. Artifacts from $41 \mathrm{CH} 62$, Labadie Site ........... 74

23. Glass and Metal Artifacts from $41 \mathrm{CH} 62$, Labadie Site . . . . . 76

24. Map of $41 \mathrm{CH} 57$....................... 84 



\section{LIST OF FIGURES (continued)}

Figure

Page

25. Taken from Map of Spanish Establishments on Lake Miller in $1776 \quad 86$

26. Spanish and Indian Artifacts . . . . . . . . . . . . 88

27. Views of $41 \mathrm{CH} 22$ and $41 \mathrm{CH} 54$. . . . . . . . . . . . . . . . 94

28. Map of $41 \mathrm{CH} 22$ (Indian Camp) and $41 \mathrm{CH} 54$ (Mission La Luz). . . . 96

29. Map of the Town of Wallisville at the Turn of the Century . . . 106

30. View of Courthouse and Jail with Hanging Tower from Northeast on Courthouse Avenue ............... 108

31. View of Shelton House from Courthouse Square. . . . . . . . . . 110

32. Map of Shelton House Site. . . . . . . . . . . . . 113

33. Map of Shearer House Site. . . . . . . . . . . . . 118

34. View of Wallis House .................. . . 121

35. Map of Wallis House Site . . . . . . . . . . . . . 122

36. Main Street, Looking East... . . . . . . . . . . . 124

37. View of Church and Parsonage . . . . . . . . . . . . . 125

38. Personal Objects from Wilson Boarding House . . . . . . . . . . 128

39. Ceramics from Wilson Boarding House . . . . . . . . . . . 130

40. Glass from Wilson Boarding House . . . . . . . . . . . 132

41. View of Cummings Mi11 . . . . . . . . . . . . . . . 143

42. Views of Features at Mi11................ . . . 145

43. Map of Cummings Mi11 . . . . . . . . . . . . . . . . 146

44. Scale Drawing of Feature 1, Cummings Mil1 . . . . . . . . . . 147

45. Scale Drawing of Feature 2, Cummings Mil1 . . . . . . . . . . . . 148

46. South Profile of Test Pit 1 at Feature 2, Cummings Mi11 . . . . . 150

47. Scale Drawing of Feature 3, Cummings Mil1 . . . . . . . . . . 151

48. Profile of Test Pit 2 at Feature 3, Cummings Mil1 . . . . . 152 


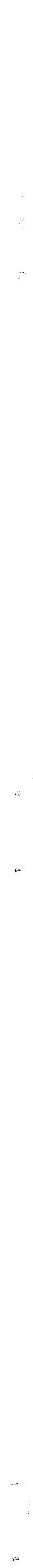




\section{LIST OF FIGURES (continued)}

Figure

Page

49. View of J. J. Mayes Farm and Family ............. 154

50. Wallisville Area ca. 1930 .............. 155

51. Map of Almeras Kiln .................. 159

52. Trench B Across Kiln Walt . . . . . . . . . . . . 160

LIST OF TABLES

Table

Page

1. Prehistoric Sites Inspected .............. 9

2. Provenience of Unidentifiable Sherds, 41 LB 48 . . . . . . . 12

3. Provenience of Identifiable Sherds, 41 LB 48 . . . . . . . 13

4. Provenience of Flakes and Flake Fragments . . . . . . . . . 16

5. Identified Vertebrates from 41 LB 48 . . . . . . . . . 17

6. Site Provenience of Prehistoric Ceramics . . . . . . . . . 36

7. Artifact Provenience, $41 \mathrm{CH} 62$............ 68

8. Identified Vertebrates from $41 \mathrm{CH} 62$. . . . . . . . . 78

9. Identified Vertebrates from $41 \mathrm{CH} 57$. . . . . . . . . 92

10. Identified Vertebrates from $41 \mathrm{CH} 22 \ldots . . . . . . . . .97$

11. Identified Vertebrates from $41 \mathrm{CH} 54$. . . . . . . . . . 101

12. Artifact Proveniences, Wallisville Project .......... 111

13. Identified Vertebrates from $41 \mathrm{CH} 237$. . . . . . . . . . . . 114

14. Identified Vertebrates from $41 \mathrm{CH} 239$. . . . . . . . . . 134

15. Analysis of Historic Sites ............... 164 



\section{ACKNOWLEDGMENTS}

Numerous people in Chambers and Liberty Counties contributed to the success of this project. Our profound thanks and respect go to Mrs. Villa Mae Williams, Chairman of the Chambers County Historical Commission, and to her husband, Judge Floyd Williams; and to John Middleton, worthy descendant of $E$. $H$. R. Wallis and enthusiastic Wallisville historian. These people provided every conceivable kind of aid and comfort, opened al1 doors, and arranged interviews. Susan Middleton provided good food and helped in many ways. The painstaking research of Ann Mullins has been of tremendous help, particularly in piecing together the history of the Lake Charlotte area. The research was aided greatiy by the kindness of historian John Clay, who shared with us all of his carefully translated Spanish documents and freely gave his time and knowledge to the project, and by Joyce Calhoon, archivist at the Rayburn Library in Liberty. Our landlords, Mr. and Mrs. John Bradley, and our boatman, Ralph Comeley, also deserve special thanks.

Local informants who were particularly helpful included Mrs. Gladys Avery, G. C. Chambless, Harry Daves, Wilbur Dugat, Mrs. Octavia La Four, J. B. Mayes, Mrs. Jean McGinty, Mrs. J. D. McManus and sons David and Dennis, George Munger, Mr. and Mrs. W. C. Porter, J. Romain Sherman, and Billy Earl Sylvia.

To all the enthusiastic members of the Houston Archeological Society and other volunteers who helped in the testing of the presidio site we owe a special debt of gratitude, and particularly to Dick Gregg who supervised and wrote the section describing the magnetometer survey and to Bill McClure who supervised the core testing operation.

Help and guidance were freely offered by Lou Fullen, who shared the information from earlier testing of the presidio site and his knowledge of the archaeology of the lower Trinity River valley. Lawrence Aten graciously allowed us the use of portions of his unpublished dissertation on the archaeology of the area.

Dr. Barbara Butler and Bonnie Yates of the Institute of Applied Sciences at North Texas State University did a thorough analysis of the faunal remains recovered during the project, using the collections of that institution for reference. Dr. Paul Parmalee of Knoxville aided in identification of a carp spine from $41 \mathrm{CH} 62$. Mrs. Dora Guerra of The University of Texas at San Antonio Library translated a number of Spanish documents concerning El Orcoquisac, including the inventory in Appendix III. These documents were provided through the kind cooperation of Fr. Benedict Leutenegger of the Mission San José Research Library in San Antonio. Local historian and arms expert Sam Nesmith identified the gun parts and related objects.

Shirley Van der Veer assisted with the artifact identification and tabulation. Figures 3 and 5-13 were drawn by William Goetzmann; a 71 other illustrations were prepared by the Office of Instructional Services, The University of Texas at San Antonio. Editorial assistance was provided by Alice Evett; the report was typed by Frieda Barefield. 


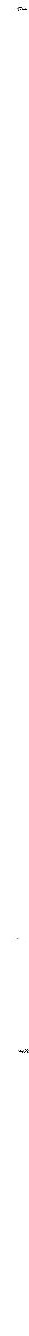




\section{INTRODUCTION}

The Wallisville Lake Project is located at the mouth of the Trinity River about 40 miles east of Houston, Texas. It was designed as a multiple purpose, 19,700 -acre reservoir to provide for salinity control, navigation, water supply, fish and wildlife enhancement, and recreation. Construction on the project was begun in 1966, but was halted by a District Court injunction in 1973 because of deficiencies in the environmental impact statement and procedures used by the Corps of Engineers. The U.S. Court of Appeals, Fifth Circuit, reversed the decision in 1974, but left the injunction in force pending revision of the environmental impact statement and a new District Court determination (Corps of Engineers 1977:2).

In 1977, after considering several alternate plans, the Corps of Engineers recommended a smaller project known as Plan $2 \mathrm{~A}$. This would reduce the original lake to 5,600 acres, confined by gated diversion structures and overflow dams to an area east of the Trinity River. The plan also includes a park site for recreational purposes on the northeast shore of Lake Charlotte. The level of the water in the lake would be maintained at a maximum elevation of four feet.

Scope of Work

In June 1979, the Center for Archaeological Research, The University of Texas at San Antonio, contracted with the Galveston District, U.S. Corps of Engineers, to perform archaeological and historical investigations of Wallisville Lake, Texas. Although previous archaeological surveys of the project area identified nearly 200 prehistoric sites, as well as an area of French, Spanish, and Anglo occupation which was nominated to the National Register of Historic Places, additional survey was needed to record and assess other prehistoric and historic sites within the reservoir area.

Five separate items were included in the scope of work:

1. Historic reconnaissance and survey. "Literature review and field search to identify, locate, and evaluate sites important in National, State, or local history" on all property which has been acquired for the Wallisville Lake project (Corps of Engineers 1979a:2). Reconnaissance-level investigation was to be conducted on lands west of the Trinity River, and survey-level investigations on a 500-foot wide strip on the west bank of the Trinity River and a 11 project lands east of the river. Particular attention was to be paid to stipulated areas where control structures are to be located.

2. Prehistoric survey. Survey-level investigation to locate and identify prehistoric sites in areas within the limits of the proposed reservoir which had not previously been surveyed. This included an area east of the Trinity River and north of the boundary Tine between Liberty and Chambers Counties.

3. Literature search for historic shipwrecks. A review of literature and interviews of local residents who have knowledge of the location of such shipwrecks. No field work would be required. 
4. Determination of boundary of $41 \mathrm{CH} 57$. A 1iterature review and test excavations where required to delimit the northern boundary of this site and to determine if a wharf and ship once occupied this location.

5. Field reconnaissance of known sites. "A field reconnaissance of known cultural sites in the area with a view to determining the probable effects of the proposed plan and identifying any needed protection or mitigative measures" (ibid.:3).

All sites were to be evaluated for cultural significance, educational value, and potential for producing additional archaeological or historical data. Assessments of eligibility for inclusion on the National Register of Historic Places were to be made and sufficient description and historic background included to allow nominations to be composed.

Potential effects of project construction, operation, and maintenance on cultural resources were to be described as well as the loss of scientific, cultural, or educational value which would result. Recommendations for protection or mitigation measures should be made, including sufficient detail to allow designing and budgeting of cost.

Methodology

The field work was accomplished in July and August 1979 by a crew consisting of Assistant Director Robert Scott and crew members Kenneth Brown, William Day, and Paul Lukowski under the supervision of Anne Fox as project director. Principal investigator for the project was Dr. Thomas R. Hester, with Jack D. Eaton serving as co-principal investigator.

The first portion of the work consisted of historical and archival research in Chambers and Liberty Counties, and a survey-level investigation of the project lands north of the Liberty-Chambers county line and east of the Trinity River. The survey was carried out on foot and by boat and covered $100 \%$ of the bluff on the eastern and northern edge of the project as well as the entire shoreTine of Mac's Bayou and the eastern shore of the Trinity River. Choice of areas to be examined was dictated partially by terrain and accessibility and partly as a result of study of site locations recorded by previous surveys and interviews with local inhabitants. One new prehistoric site (41 LB 48) was recorded and archaeologically tested. One historic site (41 LB 49) was examined and recorded.

The second portion of the field work consisted of four activities which were carried out simultaneously: additional archival research and interviews, a reconnaissance of historic sites west of the Trinity River, a survey for historic sites in a 500-foot strip west of the river and all project lands east of the river, and a reconnaissance of all known sites to be affected by Plan 2A. This was done in order to most efficiently use the time allotted with the personnel involved, taking into consideration the problems encountered with weather and boat transportation. By working on all phases of the project at the same time, information gleaned from continuing archival research and interviews with local informants could be quickly checked out by survey. 
Boat trips to survey historic sites could also be used to examine the condition of previously recorded prehistoric sites. When bad weather precluded one type of work, another type could be successfully undertaken, and comparatively few hours of field time were lost despite the arrival of a tropical storm and subsequent extreme flooding during the project.

Standard archaeological field techniques, as described below, were used in all phases of the project, and complete field notes and records are on file at the Center for Archaeological Research. Test excavations were executed in $10-\mathrm{cm}$ levels unless otherwise dictated by stratification. Records were kept on each leve1, and the soil was screened through 1/4-inch mesh. Artifacts were placed in properly labeled bags and washed, labelled, and cataloged in the laboratory. Plans and profiles were recorded for later use in analys is.

Newly discovered sites were recorded in detail on site survey forms, plotted on USGS quadrangle maps, and registered with the Texas Archeological Research Laboratory in Austin. Each site was assigned a trinomial number which indicates the state $(41)$, the county $(\mathrm{LB}, \mathrm{CH})$, and the individual site number.

While the field work was progressing, Lab Director Janet Stock was processing forms and cataloging artifact collections as they came in from the field. Historical researcher Lynn Highley collected and studied all known published references on the history of the Wallisville area from the time of Spanish contact to the early 20th century. Copies of a group of heretofore unexamined Spanish documents which pertained to the Wallisville area were acquired from the Mission San José Research Library, and summarized translations were prepared by Dora Guerra of The University of Texas at San Antonio Library for use with the project. Highley also carried out extensive research into the technology of 19th-century lumbering, brickmaking, and shipping.

Near the end of the project, particular attention was given to the area within the National Register District on Lake Miller. With the help of a large group from the Houston Archeological Society, testing was done to delimit and examine the northern boundary of site $41 \mathrm{CH} 57$, the mid-18th century French Trading Post, Spanish Presidio, and Mission. Testing was carried out on the shore of Lake Miller in the vicinity of the second site of the Mission and the Indian site in order to determine what damage will be done to these sites by the reservoir, and the limits of the sites were determined and mapped.

A variety of investigative techniques were used in locating, examining, and assessing the archaeological importance of the sites within the project. In each case the method was chosen to fit the particular site and the types of information desired about the site. Because of the variety of techniques used and the great disparity in time between the earliest and latest sites, there seems no particular point to be gained by an examination of the artifacts from the historic sites as a whole in a separate section of the report. Therefore the artifacts from each historic site are described along with their investigation and utilized for interpreting that particular site. The method of presenting the artifacts is directly related to their relevance to the object of the investigation. Artifacts obtained by random surface collection to be used for general information about the site are dealt with only in general 
terms. Artifacts whose provenience is important are presented in provenience tables. Those which are important as a representative sample are listed by category. The prehistoric artifacts are treated in a more traditional manner, with a separate section for description and analysis.

Faunal remains were recovered from each site excavated, and also from a number of the sites where surface collections were made. Sampling was biased only in the size of the 1/4-inch mesh screen and the fact that no water screening was attempted on this project. No doubt the use of finer screening and water washing on site would yield a more representative sample of small rodent, reptile, and fish remains, as well as charred plant remains, from both prehistoric and historic deposits.

The report has been composed in the following manner. Lynn Highley wrote Section III and the portion of Section IV entitled "Shipwreck in Lake Miller." All of Section II was written by William Day, who also wrote "Environment" and "Archaeological Background" in Section I and who provided the analysis of prehistoric components of sites reported in Section IV. Fox coordinated the work and wrote the "Scope of Work" and "Methodology" in Section I, most of Section IV, and all of Section V. The "Vertebrate Remains" sections were written by Dr. Barbara Butler. This was truly a team effort, in which all the members contributed in numerous ways to the overall manuscript.

\section{Environment}

The Wallisville Lake area, traversed by the Trinity River, lies within a coastal zone bounded by the Hockley Scarp and the Gulf of Mexico. This zone is part of the West Gulf Coastal Plain Physiographic Province and the Coastal Lowland subdivision (Fenneman 1938:112-114). The eastern and western boundaries of the reservoir are formed by the Beaumont Coastwise Terrace (Ambler 1970:2). The interglacial periods deposited a series of Pleistocene terraces that have been cut by river valleys, such as the Trinity. The alluvial deltaic deposits in these river valleys usually date between 5,000 years and the present (Ambler 1973:2).

The Wallisville Lake area is characterized by a flat floodplain to the south and gently rolling uplands to the north. The floodplain is a marshy lowland cut by meander scars. The area is covered by grasses and isolated stands of bushes, cane, and palmettos. The uplands support dense stands of trees such as cypress, pine, sweet gum, magnolia, and aak. Large impenetrable thickets of thorny brush, briars, and mustang grape vines are common in the uplands (personal observation).

A wide variety of flora and fauna was available in the area as food resources. Roots, berries, and nuts would have been available in the forests of the Austroriparian Biotic Province (Blair 1950:99). Blair (ibid.:99-100) notes the large variety of mamma1, reptile, and amphibian species that are present in the area. Archaeological data indicate that Rangia clams, fish, alligator, turtle, migratory birds, bison, deer, and rodents were the species most often exploited by the area's prehistoric inhabitants (Ambler 1970:29; Aten 1967:69; McGuff and Ford 1974:20; faunal analysis, this report). 
Although the Trinity River delta is attractive because of its abundant food sources, it is not without its perils. Mosquitos and poisonous snakes are abundant. Flooding, because of heavy rains and/or hurricanes, can happen as often as two or three times a year. The summer months provide a stifling humidity. However, as demonstrated by more than 200 known archaeological sites in the Wallisville Lake area, human populations were able to adapt to the environment.

\section{Archaeological Background}

Archaeological investigations in the Wallisville Lake area began as early as 1932, when A. M. Woolsey (under the direction of J. E. Pearce, Chairman of the Department of Anthropology, The University of Texas) performed excavations at the Lawrence Island site (41 CH 1) and Stubbs Farm (41 CH 6) (Woolsey 1932). The Caplen site, also excavated in 1932 by The University of Texas, has been described by Campbel1 (1957). This site contained prehistoric burials, as well as one historic buriat.

The principal archaeological investigations near the area of the Wallisville Reservoir project were conducted by wheat (1953). The excavations took place in the Addicks Dam Basin, west of the Wallisville area. Aten (1967:3) reports that additional information about Addicks is available in Walley (1955), Campbe11 (1957), Ring $(1960,1963)$, and various issues of the Newsletter of the Houston Archeological Society.

Shafer (1966) investigated 47 prehistoric sites, primarily Rangia clam she11 middens, during an extensive archaeological survey by the Texas Archeological Salvage Project (TASP) of the Wallisville Reservoir area. In an additional survey project by TASP, Ambler (1970) reported on nearly 100 additional sites in and around the reservoir. These investigations have demonstrated that the majority of archaeological sites in and around the Wallisville Lake area are composed of shell middens. Also indicated is possible early contact with coastal and inland peoples located farther east.

In 1967, Aten reported on excavations at the Jamison site, 41 LB 2, located north of the Wallisville Reservoir area. Operations at this site were carried out from 1959-1961 by the Houston Archeological Society (Aten 1967).

Tunne11 and Ambier (1967) reported on excavations at the second site of Presidio San Agustin de Ahumada. Their report provides information on the historical end of the cultural sequence in the Wallisville area (Ambler 1973:4).

In 1969 and 1970 the Houston Archeological Society did minimal mapping, testing, and surface collecting on the first Presidio site, $41 \mathrm{CH} 57$. A report of these investigations is in preparation.

Further work in the Wallisville Reservoir area was undertaken by Ambler in 1973. Five previously recorded sites, $41 \mathrm{CH} \mathrm{13,41} \mathrm{CH} \mathrm{14,} 41 \mathrm{CH} 16,41 \mathrm{CH} 17$, and $41 \mathrm{CH} \mathrm{52,} \mathrm{were} \mathrm{excavated.} \mathrm{This} \mathrm{and} \mathrm{previous} \mathrm{work} \mathrm{in} \mathrm{the} \mathrm{area} \mathrm{provided} \mathrm{a}$ chronological framework for the area (Ambler 1973). 
In 1974, Gilmore reported on excavations at $41 \mathrm{CH} 110$. The focus of the report was on changes in artifact assemblages and subsistence patterns through time. Artifacts from prehistoric occupations to Spanish Colonial occupation were examined (Gilmore 1974).

Dillehay (1975) examined sites at $41 \mathrm{CH} 32,41 \mathrm{CH} 33,41 \mathrm{CH} 46,41 \mathrm{CH} 47$, and $41 \mathrm{CH}$ 172. The stated goals of this project were to examine seasonal occupations of distinct population groups.

An extensive survey of the Trinity River basin was done by the Archaeology Research Program of Southern Methodist University in 1976-77 (Richner and Bagot 1978). However, the area within the Wallisville Lake was not examined during this survey. 


\section{PREHISTORIC SITES INVESTIGATIONS}

Since so much archaeological work had previously been done at prehistoric sites within the lower Trinity River valley, the main emphasis of this project was concentrated upon the historic period sites. However, there were several prehistoric concerns which needed to be addressed before any further planning is done for Plan $2 A$, and these were included in the scope of work as outlined in the Introduction. Within the total area included in Plan $2 A$, a number of sites had been recorded by various professional and amateur archaeologists over the years. It was necessary that these sites be relocated and examined to determine their present state and to estimate the probable effect of the higher water levels created by the lake construction. Survey was needed in areas immediately surrounding planned control structures to be sure that no archaeological site would be impacted by their construction. There also was an area within the Plan $2 \mathrm{~A}$ area which had never been systematically surveyed. A survey of this area and testing of any sites located by this survey were therefore made a part of the project. Results of these efforts are reported in this section.

Since the predominant category of artifacts recovered from prehistoric sites was ceramics, an analysis and discussion of the ceramics from all prehistoric sites and components are also included in this section, in order to demonstrate the basis for dating prehistoric components of sites described in later sections.

A total of 22 previously recorded prehistoric sites due to be within the area of Plan 2A was scheduled to be examined for the projected impact of the lake upon the sites (see Fig. 1). Of these, several were nearly submerged, and three were totally inaccessible due to flooding from the tropical storm. However, the impact of the reservoir on these sites could be estimated from studying their location and elevation. Table 1 lists the assessments made of the inspected sites by Ambler in 1970 and adds the 1979 observations and some recommendations for mitigation, based on the revised size and scope of the reservoir and an overview of the resources in the entire area now owned by the United States Government in the river valley (see Section V, Summary and Conclusions).

Since numerous sites of varying ages slightly farther south on the flood plain have been surface collected, tested, and excavated, it would seem that test excavations in one or two similar sites in this area farther north should suffice to determine if they differ in any way. There does appear to be a lack of emphasis on valley wall sites in past excavation strategies, and for this reason we suggest testing of a few of these to determine if there were differences in seasonal occupation and what types of resources were being utilized in these locations.

\section{Survey of Control Structures}

As part of the project, a survey was made in the areas specified to be projected sites for control gates and other structures on 01d River and the Cutoff (Fig. 15, Section IV). Neither area was found to contain archaeological sites. In the process of surveying, however, two sites were noted nearby. 
This page has been

redacted because it

contains restricted

information. 


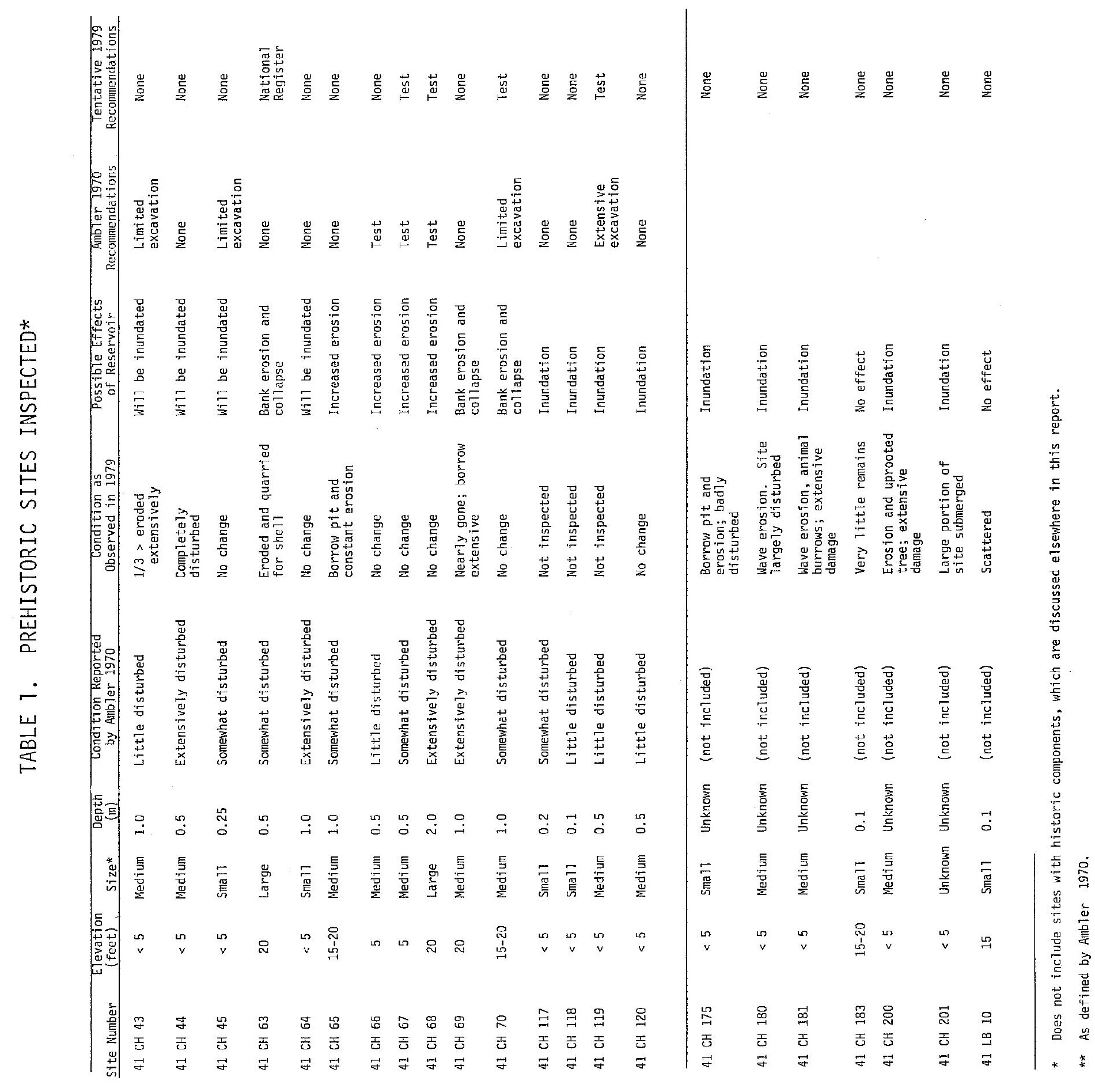


41 LB 4 is a shel1 midden exposed in the bank of the Cutoff (Fig. 1). It was first recorded by Ambler in 1968, and is estimated to cover an area of $25 \times 25 \mathrm{~m}$. Some testing has been done on this site, and additional testing has been recommended, primarily because a trade bead was found, indicating that it was occupied during historic times. On this basis, it has also been placed on the National Register of Historic Places, in connection with the Orcoquisac Historic District.

$41 \mathrm{CH} 236$ is a newly recorded shell midden located on the southern shore of the Cutoff (Fig. 1). The site is approximately $10 \times 25 \mathrm{~m}$ and occupies a zone from 50 to $80 \mathrm{~cm}$ in depth below the surface. Mixed with the shell is a variety of 1ithic debris, bones, and ceramics. One distal end of a biface and one bonetempered sherd were found. Additional artifacts recovered from the surface of the site include one burned chert chunk, one petrified wood chunk, three secondary flakes, two tertiary flakes, eight grog-tempered sherds, two sandtempered sherds, one clayey- and/or silty-tempered sherd, and 14 sandy paste untempered sherds. Artifacts recovered suggest a late occupation. The site may provide data on aboriginal occupation at or near the time of Spanish contact. Wave action is eroding and undercutting the site. Further testing is recommended before more damage occurs.

Tested Sites

Six prehistoric sites were tested and/or surface-collected during the current project. Three of these sites contained historical components: $41 \mathrm{CH} 54$, 41. $\mathrm{CH}$ 57, and $41 \mathrm{CH} \mathrm{62;} \mathrm{and} \mathrm{one,} 41 \mathrm{CH} 22$, is directly associated with a historic site. These four sites will be described in the Historic Sites Investigations section. The future of $41 \mathrm{CH} 63$ is more fully discussed in conjunction with $41 \mathrm{CH}$ 62. Prehistoric site 41 LB 48, the only prehistoric site recorded during the survey of the unexamined area within Plan $2 A$, is discussed below.

\section{Archaeological Investigations, 41 LB 48}

This prehistoric site is located approximately $750 \mathrm{~m}$ north of the boundary between Liberty and Chambers Counties and about $625 \mathrm{~m}$ east of Mac Lake, on the slope between the marsh and the uplands. It lies about 500 m northeast of the barge docking area for the Texas Gulf Sulphur plant. The site slopes east into a marshy swamp, and is surrounded on the north, south, and west sides by thick underbrush, trees, and vines. The area of the site is relatively clear as compared to its surroundings. Several large trees and numerous saplings are present without the dense stands of thorny brush and vines. A thick vegetation cover of fallen leaves and short grass blankets the site. A cattle path has been worn through the site in a general east-west direction (Fig. 2 ). In several small areas where the leaves had been washed or blown away, prehistoric ceramic sherds were observed. Additional examination revealed a scatter of Rangia clam shells on the east end of the site, near the top of the slope.

A series of shovel tests were employed to determine the extent of the site. A $1-m^{2}$ test pit was excavated to gain additional information about cultural material and to record a stratigraphic profile for study. 
This page has been

redacted because it

contains restricted

information. 
Four shove 1 tests were performed approximately $15 \mathrm{ft}$ apart on an east-west line across the site. They started at what appeared to be the eastern edge of the site and extended toward the west. Three to four additional shovel tests were excavated on lines perpendicular to shovel tests 1, 2, and 4 in order to establish the probable north-south boundaries of the site. A total of 14 shovel tests was dug. A stable area near the west end of the site was chosen for the test pit. It was excavated in arbitrary $10-\mathrm{cm}$ levels to a depth of $50 \mathrm{~cm}$. Artifacts recovered in the shovel tests and test pit included a large number of prehistoric sherds, Tithic chipping debris, and altered bone. Unmodified animal bone and Rangia clam shells were also present. The profile of the test pit indicated four basic depositional levels. The first level was composed of approximately $10 \mathrm{~cm}$ of grayish brown sandy loam soil covered by several centimeters of pine needles and fallen leaves. The second layer was made up of a dark brown sandy loam. It contained heavy root intrusion at the top and ranged from 10 to $30 \mathrm{~cm}$ deep. The third layer consisted of a brown compact sandy loam with a noticeable amount of clay. It appeared to be between 30 and $40 \mathrm{~cm}$ deep. The fourth depositional layer was comprised of a medium brown sandy clay mottled with darker and lighter shades and was very moist, ranging from 40 to $50 \mathrm{~cm}$ deep. The matrix of the top three layers contained cultural material, with a zone at 10 to $30 \mathrm{~cm}$ displaying the greatest concentration.

Shovel tests 9,10 , and 11, placed perpendicular to the original line of tests, yielded no cultural remains, indicating a culturally sterile area near the middle of the site. A Targe number of Rangia clam shells and a small amount of other cultural material were located on the eastern edge of the site, while the western edge produced only a few Rangia shel1s (mostly fragments) and a large amount of additional cultural material.

\section{Ceramics}

A total of 847 sherds was recovered from the 14 shovel tests and the $1-m^{2}$ test pit. Many of the sherds (366) were less than $1 \mathrm{~cm}^{2}$ in size, and their provenience is noted in the table below.

TABLE 2. PROVENIENCE OF UNIDENTIFIABLE SHERDS, 41 LB 48

Location

Surface

Shovel Test 1

Shovel Test 2

Shovel Test 4

Shovel Test 7

Shovel Test 13
№. of Sherds

$\begin{array}{r}1 \\ 4 \\ 1 \\ 2 \\ 3 \\ 2 \\ \hline 13\end{array}$

Location

Test Pit 1

Leve1 1

Level 2

Level 3

Leve 4

Level 5
No. of Sherds

$\begin{array}{r}6 \\ 96 \\ 149 \\ 87 \\ 15 \\ \hline 353\end{array}$

The remaining 481 prehistoric sherds are represented by grog-tempered, sandtempered, and sandy paste untempered types. They are described in detail in the "Analysis of Ceramics from A11 Prehistoric Sites" section. Table 3 indicates the provenience of the identifiable sherds. 
TABLE 3. PROVENIENCE OF IDENTIFIABLE SHERDS, 41 LB 48

\begin{tabular}{|c|c|c|c|c|}
\hline & $\begin{array}{c}\text { Grog } \\
\text { Tempered }\end{array}$ & $\begin{array}{c}\text { Sand } \\
\text { Tempered }\end{array}$ & $\begin{array}{l}\text { Sandy Paste } \\
\text { Untempered }\end{array}$ & Total \\
\hline Surface & 4 & & 3 & 7 \\
\hline \multicolumn{5}{|c|}{ Shovel Tests } \\
\hline 1 & 1 & & 1 & 2 \\
\hline 2 & & & 2 & 2 \\
\hline 3 & 2 & & 2 & 4 \\
\hline 4 & 1 & & 8 & 9 \\
\hline 5 & 1 & & 4 & 5 \\
\hline 6 & 2 & & 3 & 5 \\
\hline 7 & & & 3 & 3 \\
\hline \multicolumn{5}{|c|}{8} \\
\hline \multicolumn{5}{|c|}{9} \\
\hline \multicolumn{5}{|c|}{10} \\
\hline \multicolumn{5}{|c|}{11} \\
\hline 12 & & 1 & & 1 \\
\hline \multicolumn{5}{|c|}{13} \\
\hline 14 & & & 2 & 2 \\
\hline
\end{tabular}

Test Pit 1

$\begin{array}{rrrrrr}\text { Level } & 1 & 1 & & 9 & 10 \\ \text { Level } & 2 & 28 & 1 & 91 & 120 \\ \text { Level } & 3 & 19 & 2 & 167 & 188 \\ \text { Leve1 } & 4 & 11 & 2 & 91 & 104 \\ \text { Leve1 } & 5 & - & - & \underline{19} & 19 \\ \text { TOTAL } & 70 & 6 & 405 & 481\end{array}$




\section{Lithics}

A total of 70 flakes and flake fragments was recovered from site 41 LB 48 . The individual flakes have been classified as primary, secondary, or tertiary. Primary flakes are pieces of lithic material that were removed in the initial step of reduction of a cobble or in the manufacture of a stone tool. They exhibit at least $90 \%$ cortex on the dorsal surface. Those flakes classified as secondary exhibit $10 \%$ or less cortex and evidence of prior flake removals. They result from continued core reduction or the thinning process in the manufacture of the tool. Tertiary flakes have no cortex. They usually represent lithic debitage derived from the final shaping of a stone tool. Table 4 indicates the provenience of the flakes and flake fragments.

One unifacially worked flake and one bifacially worked secondary flake were recovered. The unifacial secondary flake is fashioned into a point. It has flakes removed from the dorsal side and appears to be lacking the base. The bifacially worked flake is the proximal end of a biface. There is no notching on the base; instead it is almost rectangular with rounded corners. The unifacially worked piece is from level 2 of the test pit, and the biface fragment is from level 5. One chert pebble with a single flake scar was also recovered from level 4 of the test pit.

\section{Altered Bone Fragments}

Altered bone fragments have been found at other excavations in the Wallisville Lake area. Illustrations of the artifacts excavated from 41 LB 48 are presented in Fig. 3. One specimen appears to be the end of an awl or puncturing tool (Fig. $3, d$ ). It is very polished and, as evidenced by visible charring on the fractured edge, it has been burned. Several flakes have been removed from the distal end, and wear on the sharp linear edge is visible. This particular tool was recovered from level 4 of the test pit.

An interesting bone artifact was found in level 3 of the test pit (Fig. $3, b$ ). The artifact appears to be part of a long thin bone. Incisive marks are etched into the bone perpendicular to the linear edges. The incisions do not cross the entire width of the bone. They are very fine but plainly visible--apparently cut by a sharp tool.

\section{Vertebrate Remains}

Site 41 LB 48 yielded 427 osteological fragments from a $1-m^{2}$ unit and various shovel tests. of this total, 24\% (103 fragments) had been burned. Twenty-two percent of the identifiable bone elements $(N=54)$ showed evidence of burning, and most of these were from deer (see Table 5).

The majority of the deer elements $(N=29)$ came from Unit $1-3$, where at least two individuals are indicated. A mature lumbar vertebra and first phalanx were recovered along with several sub-aduit teeth and an unfused epiphysis of a metapodial condyle fragment. An unfused femur head from Unit 1-4 may also be from the same sub-adult individual, but the wear on permanent teeth from both units indicates the presence of at least one fully mature deer. Since female white-tailed deer generally do not have antlers, an antler fragment recovered from Unit 1-4 indicates at least one individual was a buck. 

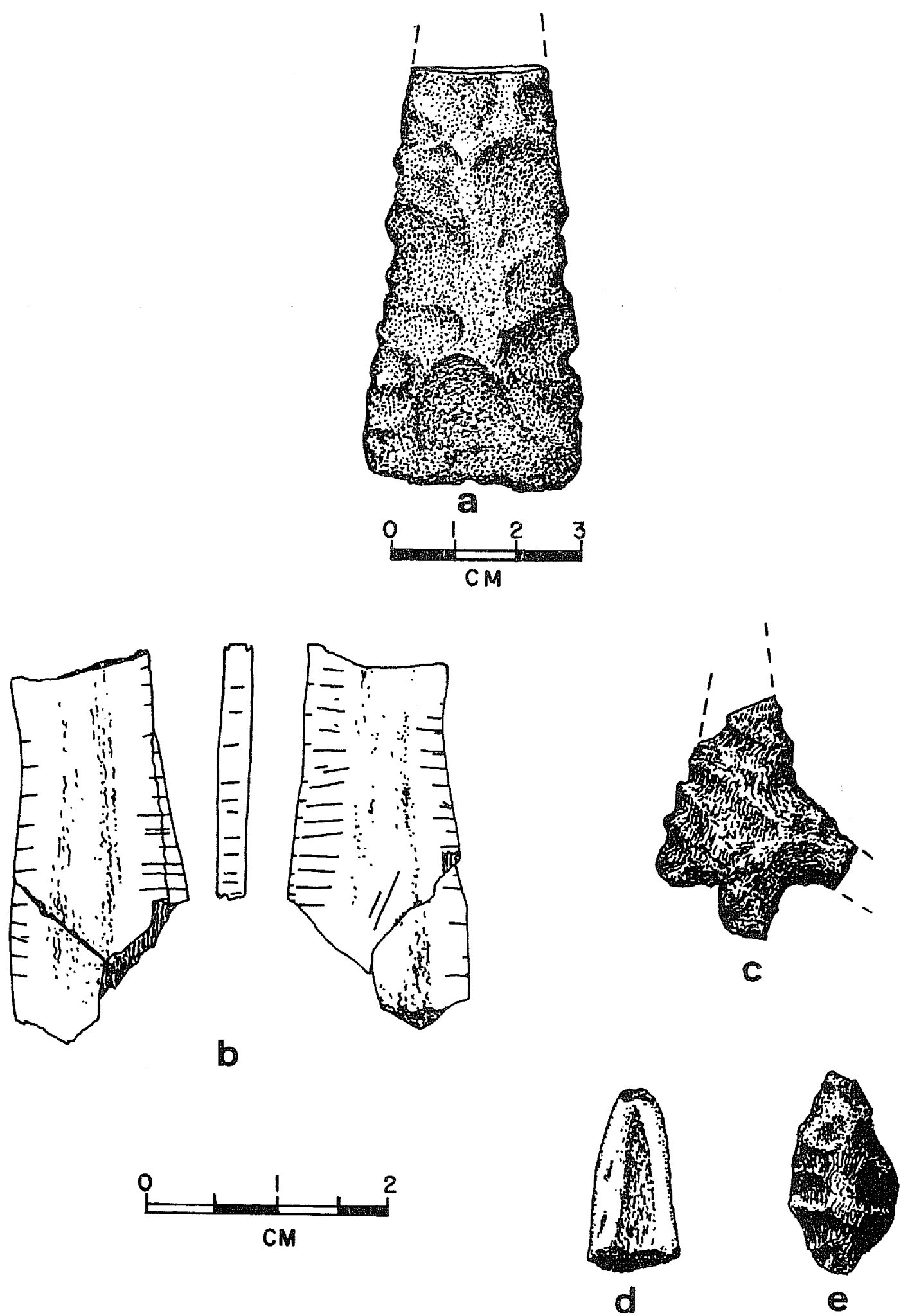

Figure 3. Prehistoric Artifacts. a, chert too 1, $41 \mathrm{CH} \mathrm{62,} \mathrm{surface;}$ $\mathrm{b}$, incised and polished bone, $41 \mathrm{LB} 48$, unit 1, level 3; c; Perdiz projectile point, $41 \mathrm{CH} 62$, unit 3 , leve1 1; d, modified bone, 41 LB 48, unit 1, level 4; e, projectile point, $41 \mathrm{CH} 62$, unit 1 , level 2. 
TABLE 4. PROVENIENCE OF FLAKES AND FLAKE FRAGMENTS

Primary Secondary Tertiary $\begin{aligned} & \text { Flake } \\ & \text { Frags. }\end{aligned}$ Burned $\begin{aligned} & \text { Petrified } \\ & \text { Frags. Wood Frags. Total }\end{aligned}$

Shovel Tests

1

5

Test Pit 1

Level 21

15

Leve1 4

Leve1 5

TOTAL
4

1

5

1

$-\quad-$

6
2

1

1

1

3 


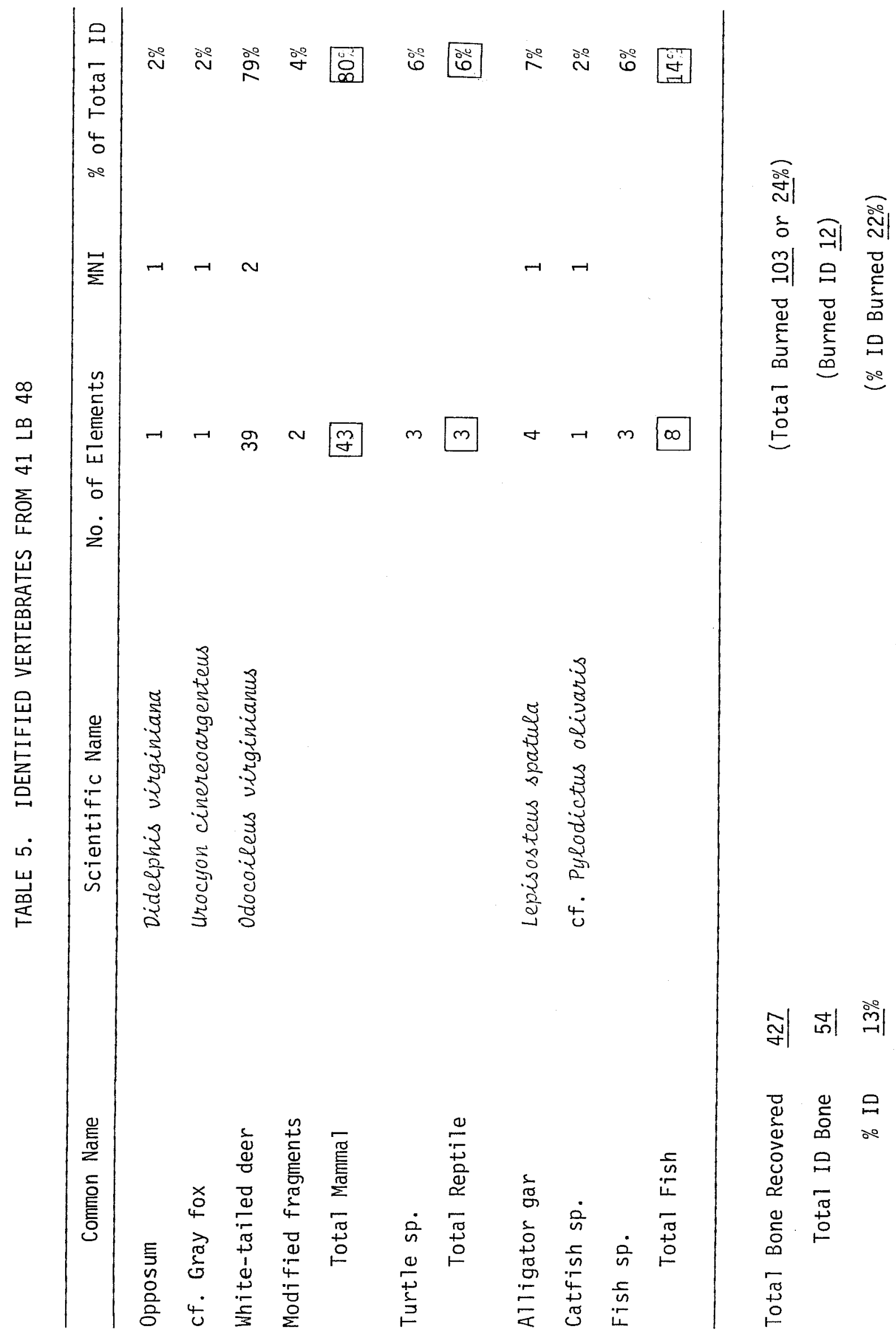


Butchering cuts appear on several of the deer elements. A left calcaneum from Unit 1-3 shows two U-shaped grooves on the lateral side about midway down the longitudinal shaft of the heel and continues around to the caudal side where it is obliterated in a fragmented area. The angle of the fragmentations on the back side seems to have been made with a downward stroke. Also, there are two lighter cuts on the lateral side parallel to the two deeper U-shaped cuts. A burned rib fragment from Unit 1-4 also has six Tight transverse cuts on the proximal end.

A tubular metacarpal shaft from Unit $1-2$ has many $V$-shaped cuts all over the surface of both sides of the bone. The more proximal end is ringed with small cuts, and the opposite end shows a spiral fracture. Directly above the spiral fracture on one side of the shaft are three deep notches each made by a series of downward slanting cuts. Another spirally fractured metacarpal shaft (from Unit 1-5) has three small curved scratches running longitudinally down the front of the bone mid-shaft near the spiral fracture and three light cuts on the inside of the broken shaft at the same end. Some smoothing on the edge of the spiral fracture was noticed under microscopic analysis, but the "wear" is not extensive enough to determine if this bone had been used as a tool.

A metatarsal fragment from Unit 1-4 has five deep-angled cuts on one broken edge and a series of lighter cuts all around one end. The uneven break at that end and the cuts associated with it resemble the cut and snap method described by Semenov (1964).

Two other deer-sized fragments have notable modifications. A small (1 cm) burned triangular fragment from Unit 1-4 has very minute cuts all around one end which have been spirally fractured. These closely spaced V-shaped cuts do not at all resemble gnawing marks, as they vary in depth and spacing. The other fragment is triangular in cross-section and is very smooth and shiny, but the thinner end has old splinter breaks and less shine, possibly indicating loss of the tool's working tip.

The remainder of the mammal assemblage shows no evidence of butchering. The opposum element is a caudal vertebra from an immature individual and shows evidence of weathering. A lumbar vertebra fragment from 1-4 most closely resembles gray fox, which is native to Liberty County.

The turtle shell fragments are unidentifiable to species. The three pieces a 11 came from Unit 1-3 and were al1 burned.

Alligator gar elements consist only of scales, and none were burned. The catfish element is a fragment of a dorsal spine from a large species, probably of the flathead variety. The remaining fish vertebrae are from a medium-sized fish.

One unidentifiable fragment is noteworthy. It is approximately $3 \mathrm{~cm}$ long and roughly shaped like the proximal end of a deer calcaneum, but it has become mineralized and probably water worn. Although smooth, it should not be confused with a bone tool as no striations of wear were observed microscopically. 


\section{other Materials}

A few isolated charcoal specimens were collected from the site. No associated features were recognized, and the samples are too small for radiocarbon dating. About 10 small fragments or balls of burned clay, $1 \mathrm{~cm}^{2}$ and smaller, were present in levels 2 and 3 of the test pit at 41 LB 48 . Similar objects have been found in various southeast and south Texas sites (Hester 1971a:15-17; 1971b:101-102; Malone 1969; Shafer 1968). They could be intentional or accidental products of hearths and cooking activities, or daub from a primitive wattle and daub structure which burned.

\section{Summary and conclusion}

A strategy of testing was employed to indicate the horizontal and vertical extent of the site. Large quantities of sherds were recovered and analyzed. The greatest number of sherds present were of the sandy paste untempered type. A fairly large number of grog-tempered sherds were recognized, and a cursory amount of sand-tempered sherds was also found. The grog-tempered sherds appeared in greater numbers in the top levels of the site. The sand-tempered sherds appeared toward the bottom of the cultural deposit. The grog-tempered sherds were present in all levels except the bottom level.

Judging from the ceramics recovered, occupation of the site may have occurred prior to A.D. 1000, but the heaviest use of the site occurred after A.D. 1000 and continued until just before or right at the time of European contact. As evidenced by the lithics found, stone tools may have been more widely used in the later occupations of the site as opposed to the early occupations. No complete diagnostic tools were found.

There are a number of possible explanations for the variations in the spatial distribution of the cultural remains. It may be that within the site there were different occupational areas used at certain seasons of the year for obtaining specific resources. They could also represent occupations from entirely separate time periods which overlapped in the same area. There also is the possibility that the two discrete deposits represent areas where differing activities were being carried out at the same time within one encampment. Further excavations would possibly provide information toward answering these questions.

The site does not appear to be in danger from increased water levels of the proposed reservoir, because of its location between the 10- and 20-foot contour lines. However, it will be endangered by private collectors gaining access to the area due to the higher water level. In the event that damage or destruction of the site becomes evident, appropriate measures should be taken either to protect or to mitigate it. Clearly, additional testing is needed to further understand the spatial and temporal data which the site deposits can provide. 
Analysis of Ceramics from All Prehistoric Sites

A thorough examination of previous ceramic analyses was undertaken. Reports by Dillehay (1975) and Ambler $(1970,1973)$ provided information on descriptive analysis techniques that have been employed on ceramic assemblages from the Wallisville Reservoir area. A lengthy attempt to accurately replicate their descriptive classification schemes using the sample of sherds collected from the five prehistoric sites tested in 1979 proved very difficult. An accurate replication was never accomplished. The sample of sherds was sorted into their descriptive categories and then re-sorted several times. Each "re-sort" yielded different results in categories such as Goose creek Plain, Wallisville Plain, and Lost River Plain. Variation in the results of the re-sorting occurred at a rate of up to $20 \%$.

Results with this amount of variation did not appear appropriate for an accurate presentation of the ceramic assemblage collected. Aten's Aboriginal Culture Ecology of the Upper Texas coast (1979) was consulted in an attempt to gain a more accurate means of classifying the ceramic assemblage. Aten's work is based on a large sample of ceramic material collected from a wide range of sites and backed by radiocarbon dates and ceramic seriation techniques. He has employed a "type-variety" classification scheme matched with a sequence of periods. The types are defined by the kind of tempering agent and whether or not it occurs naturally in the clay or has been purposefully added. The varieties consider local variations in the ceramics within the type classification. The following is a list of the types and their related varieties as described by Aten (1979).

\section{Untempered Ceramics}

Sandy Paste Untempered

Goose Creek Plain

Variety: Unspecified

Variety: Anahuac

Goose Creek Incised

Goose Creek Red Filmed

Goose creek Stamped

Mandeville Plain

Clayey or Silty Paste Untempered

Tchefuncte Plain

Tchefuncte Incised

Tchefuncte Stamped 
Tempered Ceramics

Sand-Tempered

O'Neal Plain

Variety: Conway

Grog-Tempered

Baytown Plain

Variety: San Jacinto

Variety: Phoenix Lake

San Jacinto Incised

Variety: Jamison

Variety: Spindletop

Bone-Tempered--Included both Plain and Incised variations.

Aten's ceramic sequence provides a clear temporal framework for the development of prehistoric ceramics through time. Fig. 4 is a chronological chart developed from Aten's and others' previous work.

The current study relies heavily on Aten's work. Replication of the previously mentioned type categories was accomplished with a $1 \%$ to $2 \%$ margin of error on the second sort and less than $1 \%$ on the third and fourth sorts. Clearly, there are other difficulties to be considered when analyzing a collection of prehistoric ceramics from the Wallisville Reservoir area. Those additional problems are thoroughly discussed by Aten, and further discussion is not warranted here.

It is the intent of this study to provide information on the kinds of ceramics and how they relate to the overall prehistory of the Wallisville Reservoir area. In accordance with the distribution and size of the sample and the classification system employed, this aim is met using the type categories. In certain cases some information on the varieties will be provided. This is not a replication of Aten's work but the formation of a means of analyzing the sherds at hand for the desired information, based on Aten's work.

The first step in the ceramic analysis involved washing and cataloging the sample. Each sherd was carefully washed by hand to insure that no damage was done to the surface by excessive scrubbing. The sample size and provenience were recorded on standardized catalog sheets, including a general description. Labeling of the individual sherds was avoided, since the labels could cover up surface features of the sherds. The collection of sherds was grouped by the site number and provenience from which they had been recovered. Al1 sherds less than $1 \mathrm{~cm}^{2}$ were eliminated from the sample. Some sherds smaller than $1 \mathrm{~cm}^{2}$ had a tendency to crumble, making microscopic examination and assessment of surface features nearly impossible. A total of 644 sherds was thus eliminated. 


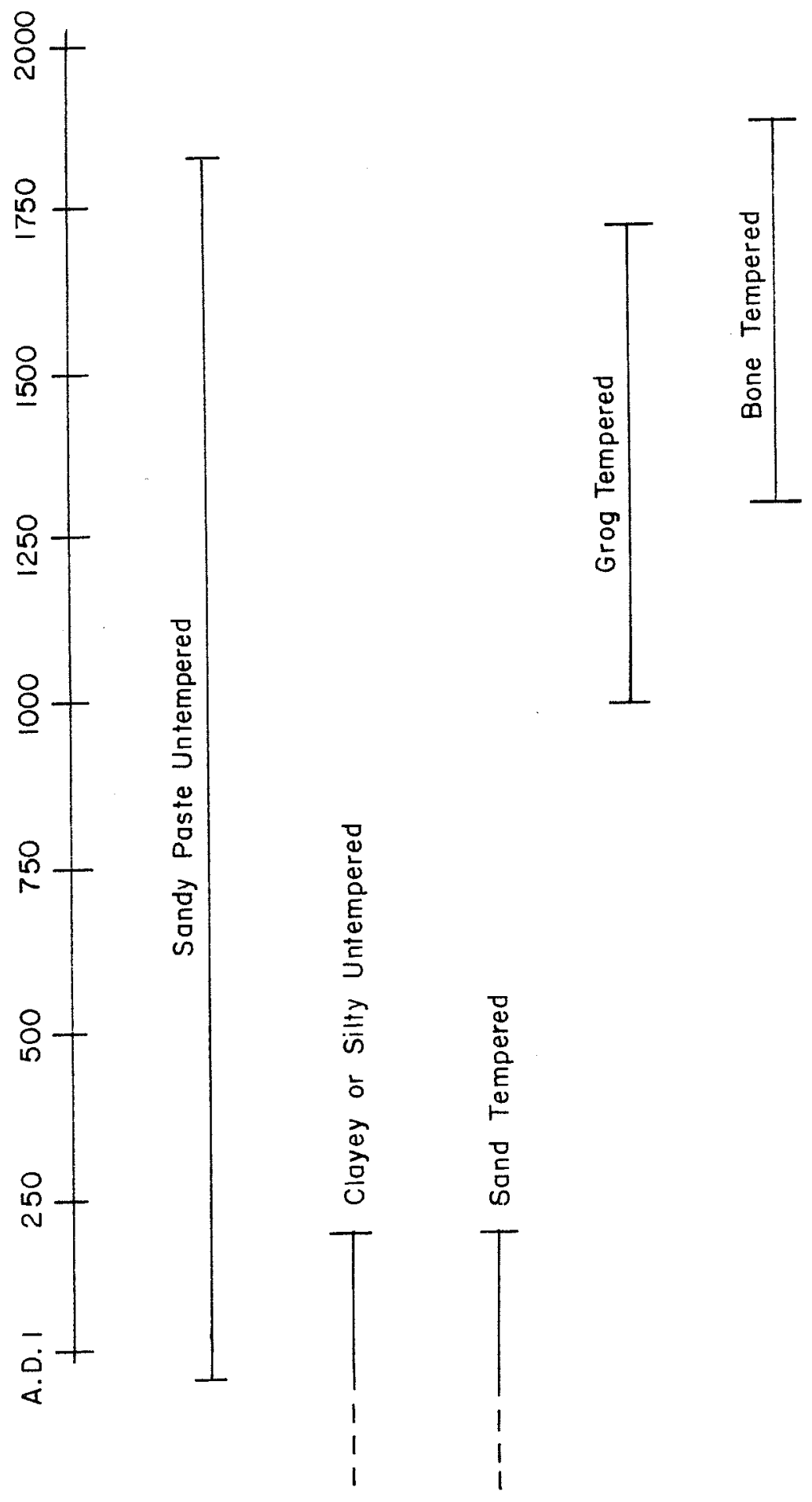

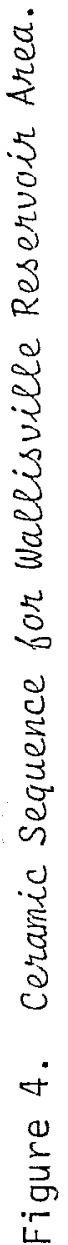


A fresh break was performed on each specimen within the remaining sample of sherds, and microscopic examination at 20X power was made of the paste and the surfaces. A determination of the type was made, based on the microscopic examination, and each sherd was placed in a box labeled with the appropriate type according to the site and provenience. On completion of sorting the sample, all sherds were reassembled according to site and provenience and resorted into their appropriate types. The process of sorting the sherds into types was carried out four times. The breakdown of the types of ceramics by the site is recorded in Table 6 .

The majority of the sample were recovered from $41 \mathrm{CH} 62$ and 41 LB 48 . Grogtempered sherds are dominant. Bone-tempered sherds were not found on the five prehistoric sites tested. However, one was recovered from a newly recorded site, $41 \mathrm{CH} 236$. Sand-tempered sherds and clayey or silty paste-tempered sherds were present at $41 \mathrm{CH} 62$ and 41 LB 48 . They make up only a smal1 percentage of the total sample studied. Additional data on the ceramics is presented within the site descriptions in Section IV. Ceramics recovered are illustrated in Figs. 5 through 13. 


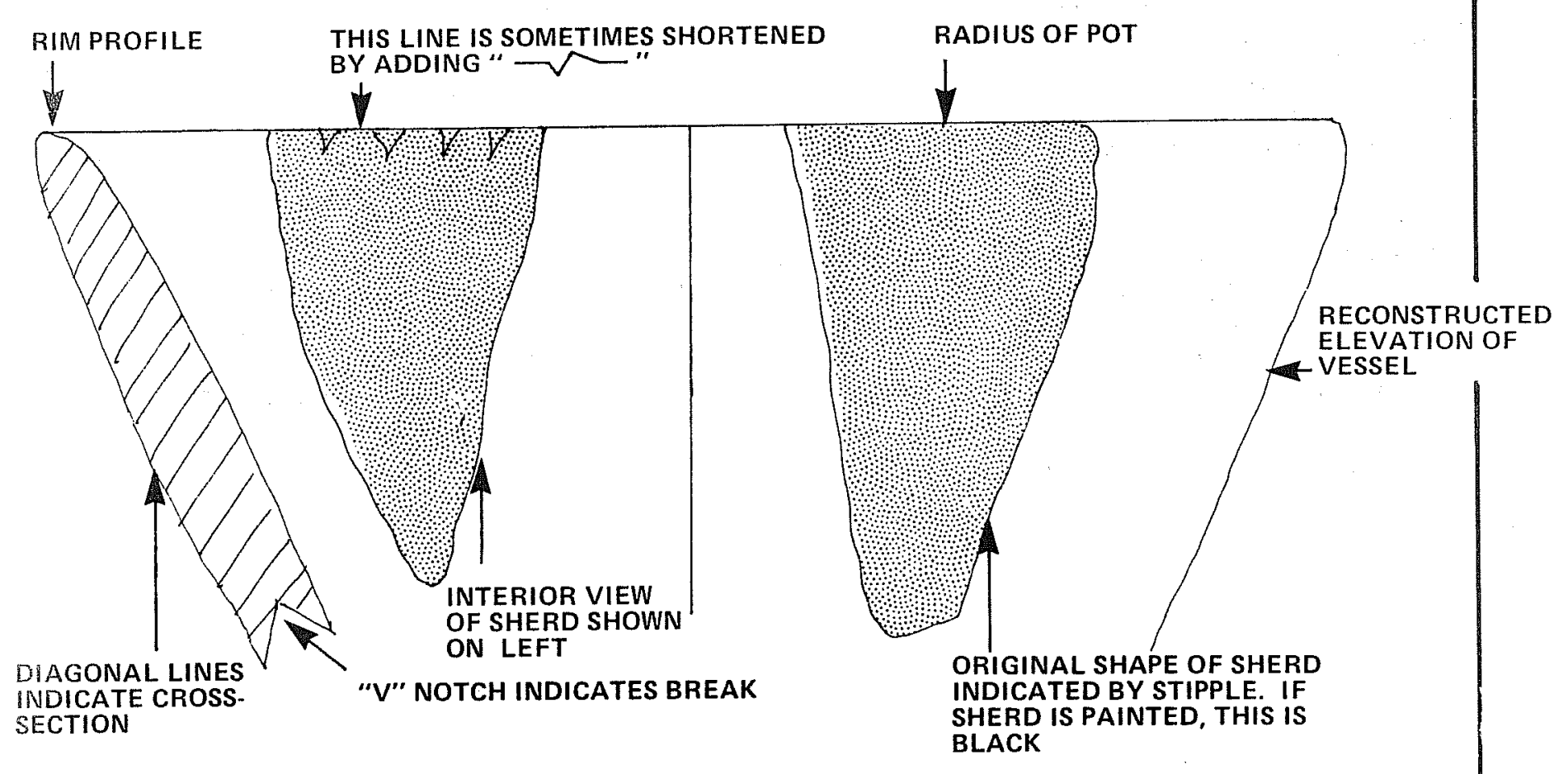

SHERD ALL BLACK (RED FILMED)

STIPPLED LINES INDICATE INCISING

STIPPLED LINES INDICATE INCISING

1

00

SOLID OUTLINE SHAPES $==$ HOLES OR PUNCTATIONS

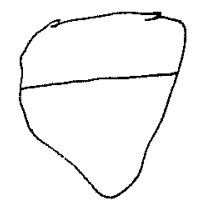

SOLID LINE ACROSS INDICATES CARINATIONS

CROSS SECTION ON LEFT, EXTERIOR FACES LEFT

Figure 5. Key to Ceramic Illustrations. 


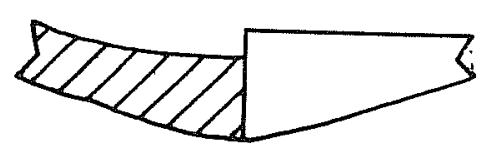

a
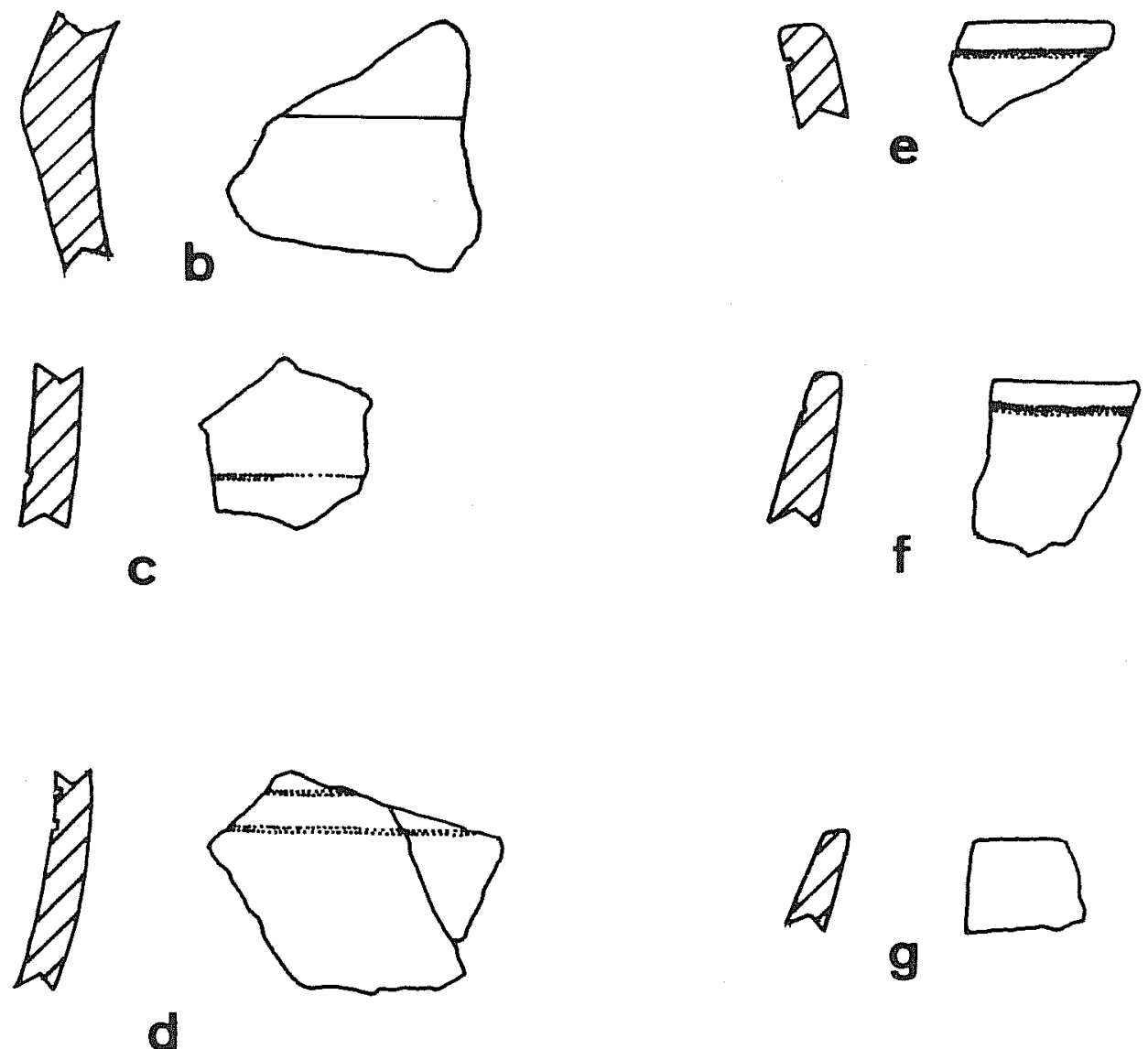

$\mathrm{g}$

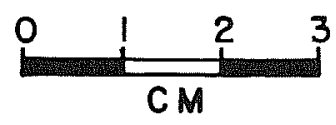

Figure 6. Grog-Tempered and untempered Ceramic Sherds. a, base, clay, or silt, untempered, $41 \mathrm{CH}$ 62, unit 3, level 3; b, carinated body, grog temper, 41 LB 48, unit 1, level 2; c, incised body, grog temper, $41 \mathrm{CH} \mathrm{62,} \mathrm{Test} \mathrm{A-3;} \mathrm{d,} \mathrm{incised}$ body, grog temper, 41 LB 48, Test 5; e, incised rim, grog temper, 41 LB 48, unit 1, level 2; $f$, incised rim, grog temper, unit 1, level 3; g, rim, grog temper, 41 LB 48 , unit 1 , level 4 . 

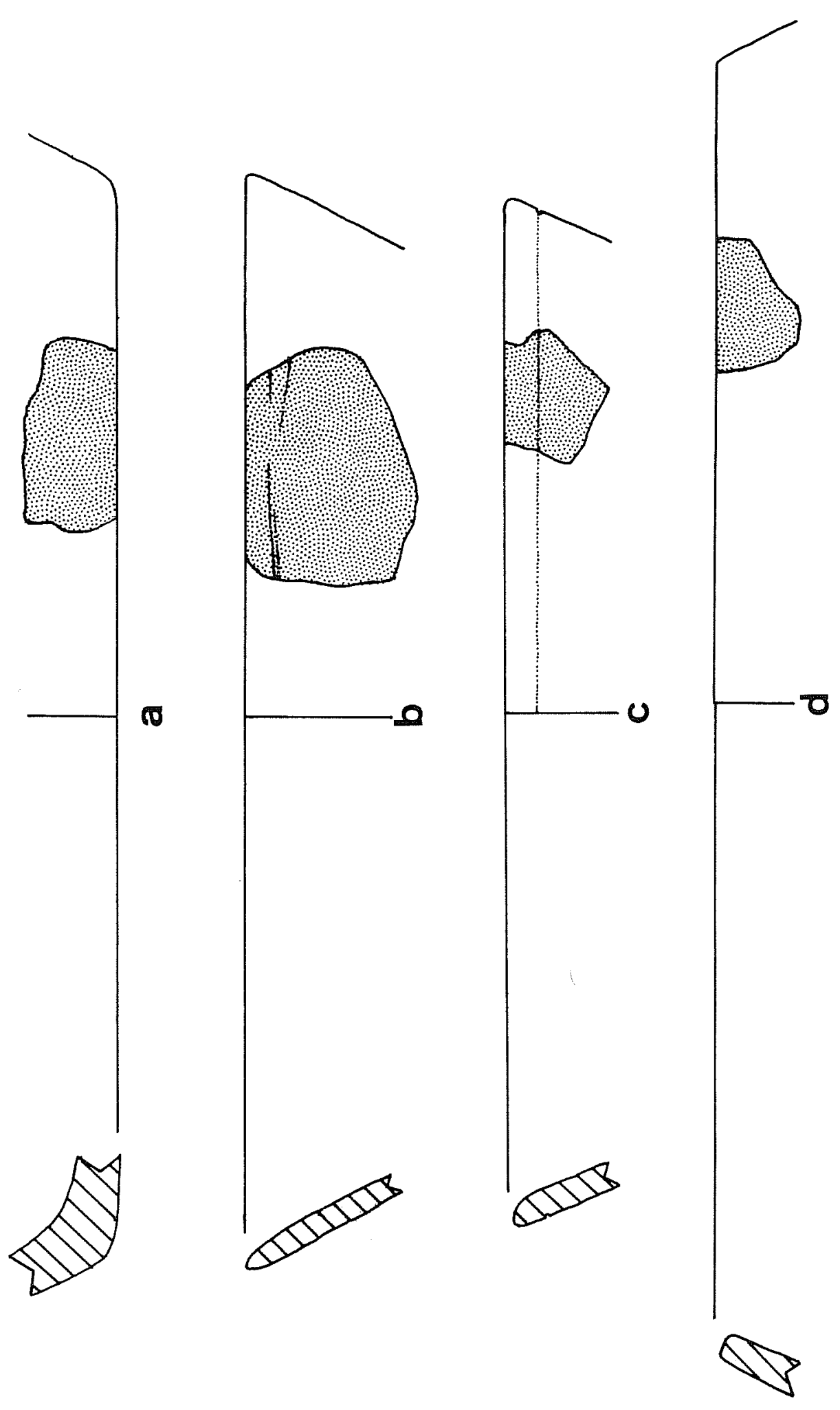

हᄐ

คำ

$\ddot{m} \stackrel{\oplus}{5}$

is.

必

(1)

으맘

in

ก ก

I ه

चㅁ

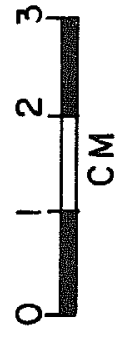

造交

드

هิ

品

S

जे

ص

근

ऽ。

¿

긍.

ठ

ㅇํㅇ

$\frac{\partial}{1}$

눈

ก ชิ

ई工

吕要 

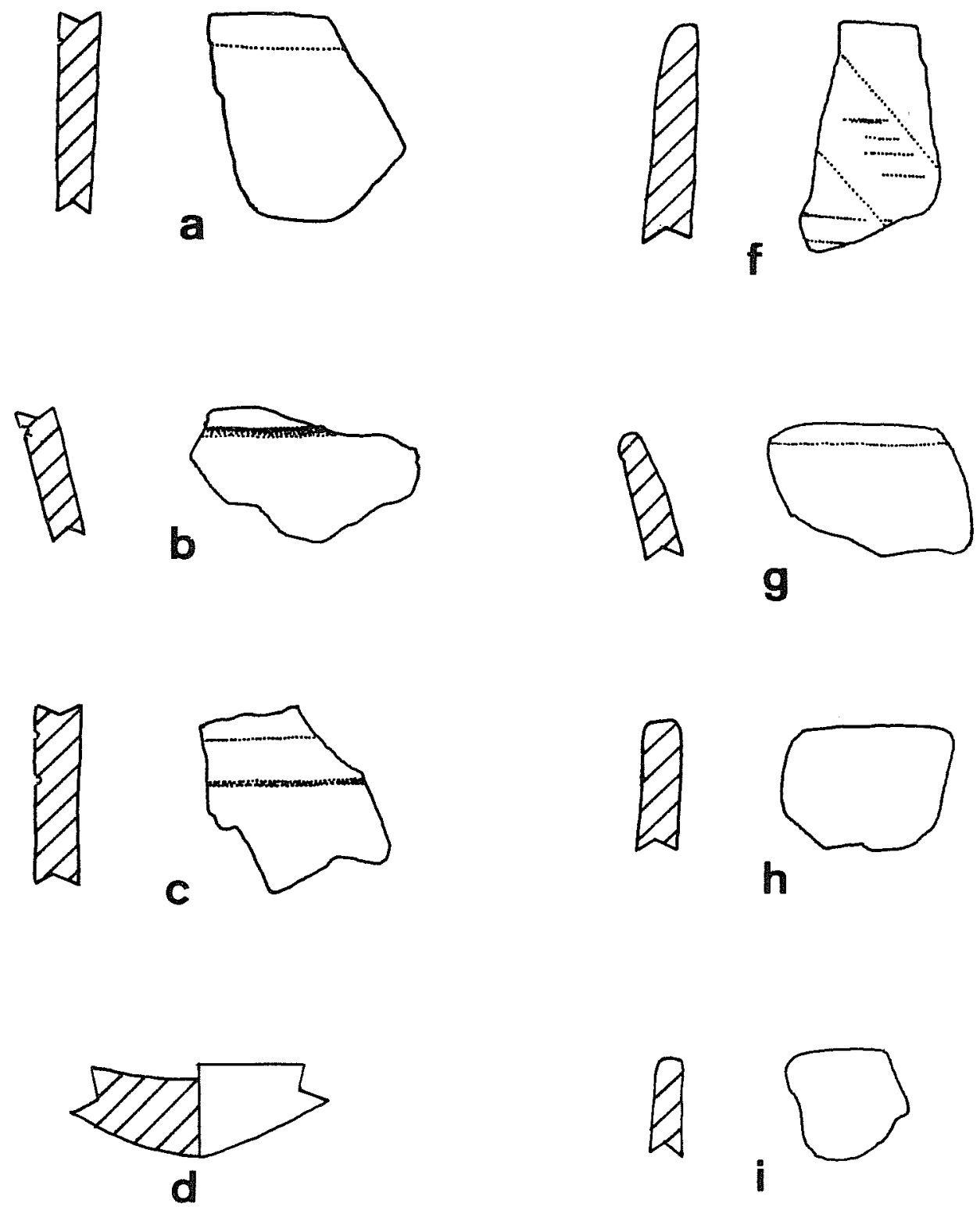

$\theta$
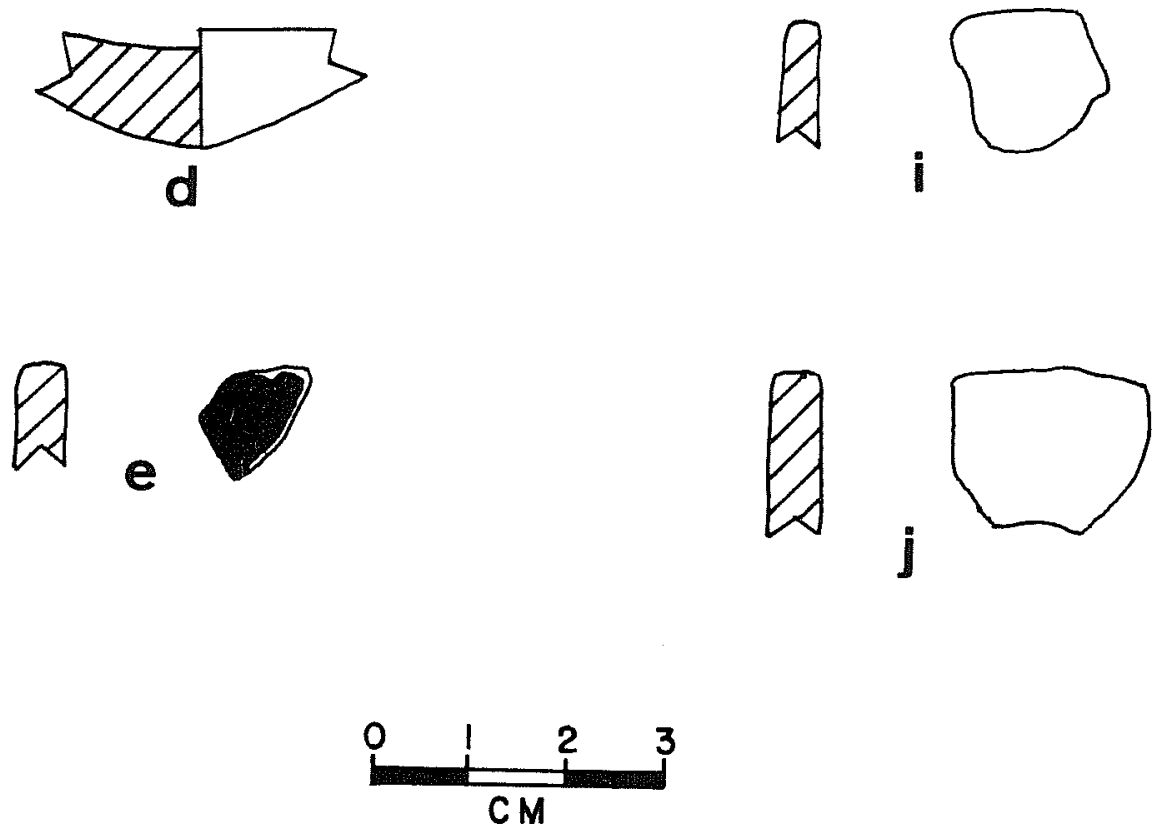

Figure 8. Sandy Paste untempered ceramic Sherds from Surface of $41 \mathrm{CH}$ 62. a-c, incised body; d, noded base; e, rim, red slipped; $f-j$, rim. 


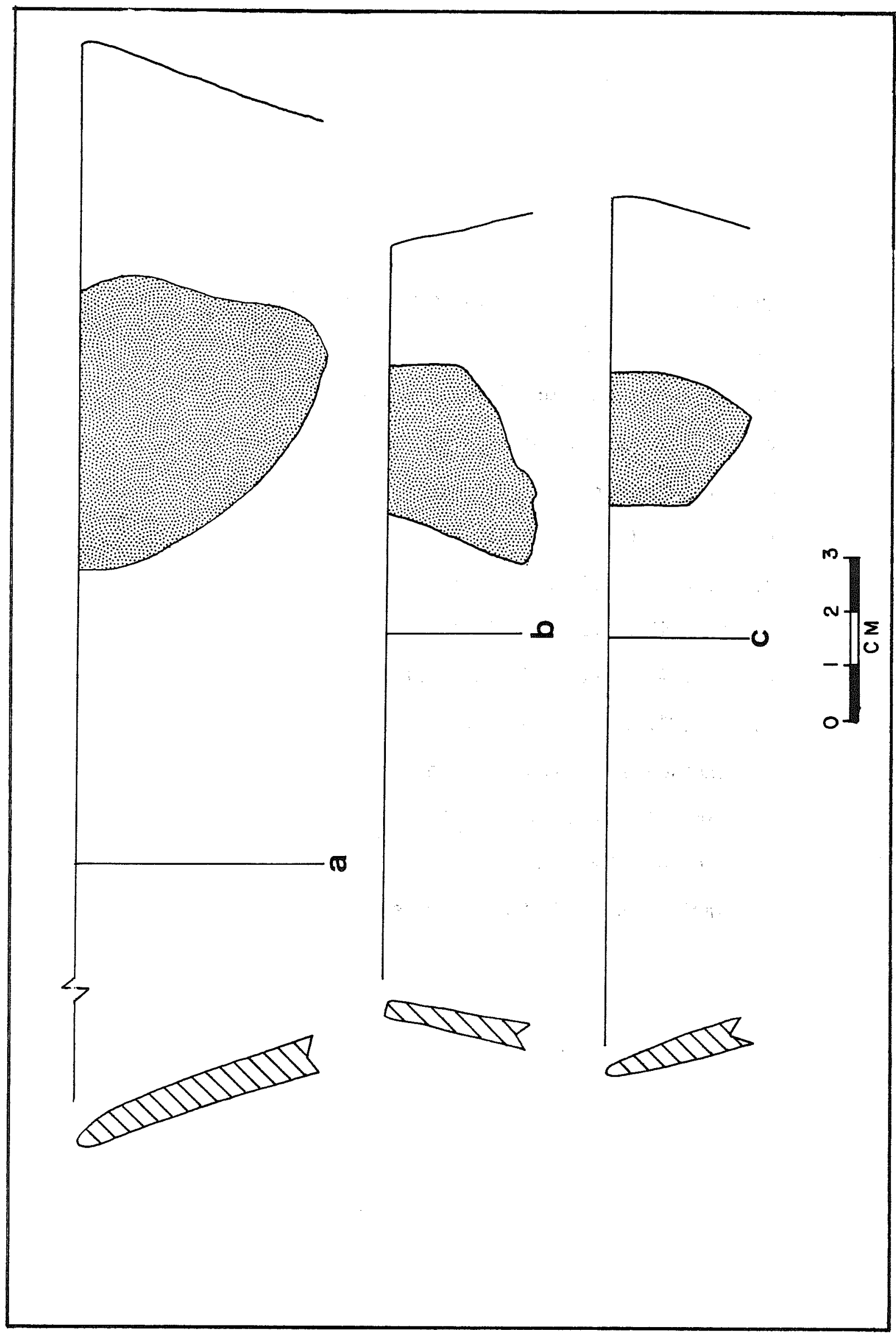

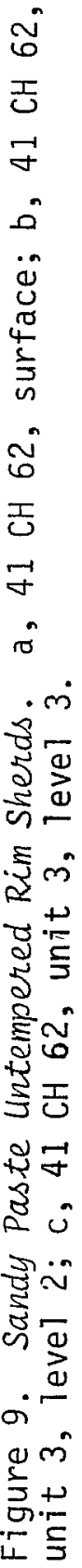


Figure 10. Sandy Paste Untempered Ceramic Sherds.

a. rim, $41 \mathrm{CH} 62$, unit 1 , leve 11

b. rim, red exterior, $41 \mathrm{CH} 62$, unit 1 , level 2

c. rim, $41 \mathrm{CH} 62$, unit 2, leve1 2

d. rim, $41 \mathrm{CH} 62$, unit 3 , level 1

e. rim, $41 \mathrm{CH} 62$, unit 3 , leve1 1

f. rim, $41 \mathrm{CH} 62$, unit 3 , level 2

g. rim, $41 \mathrm{CH} 62$, unit 3 , level 3

h. rim, $41 \mathrm{CH} 62$, unit 3 , level 3

i. rim, $41 \mathrm{CH} 62$, Test $\mathrm{B}-3$

j. incised body, $41 \mathrm{CH} 62$, Test A-5

k. rim, $41 \mathrm{CH} 62$, balk

1. rim, $41 \mathrm{CH} 62$, balk

m. incised body, $41 \mathrm{CH} \mathrm{57,} \mathrm{Shove1} \mathrm{Test.} 1$ 


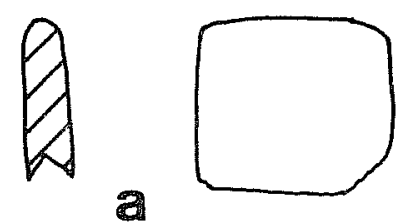

$B$ b
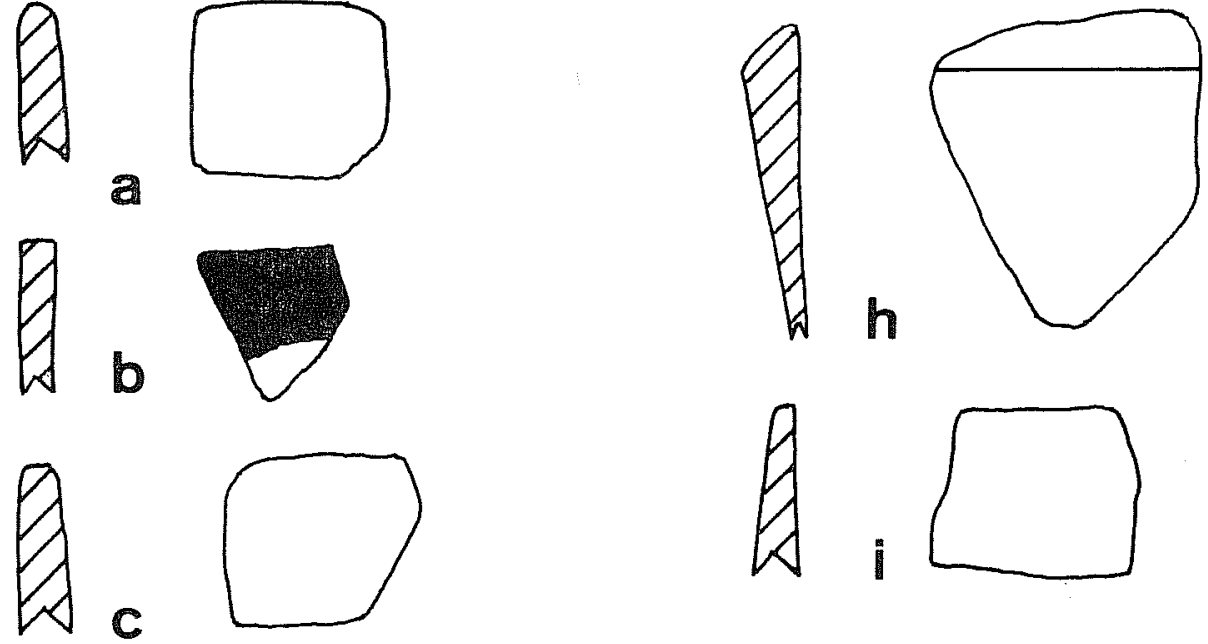

$M d \square$
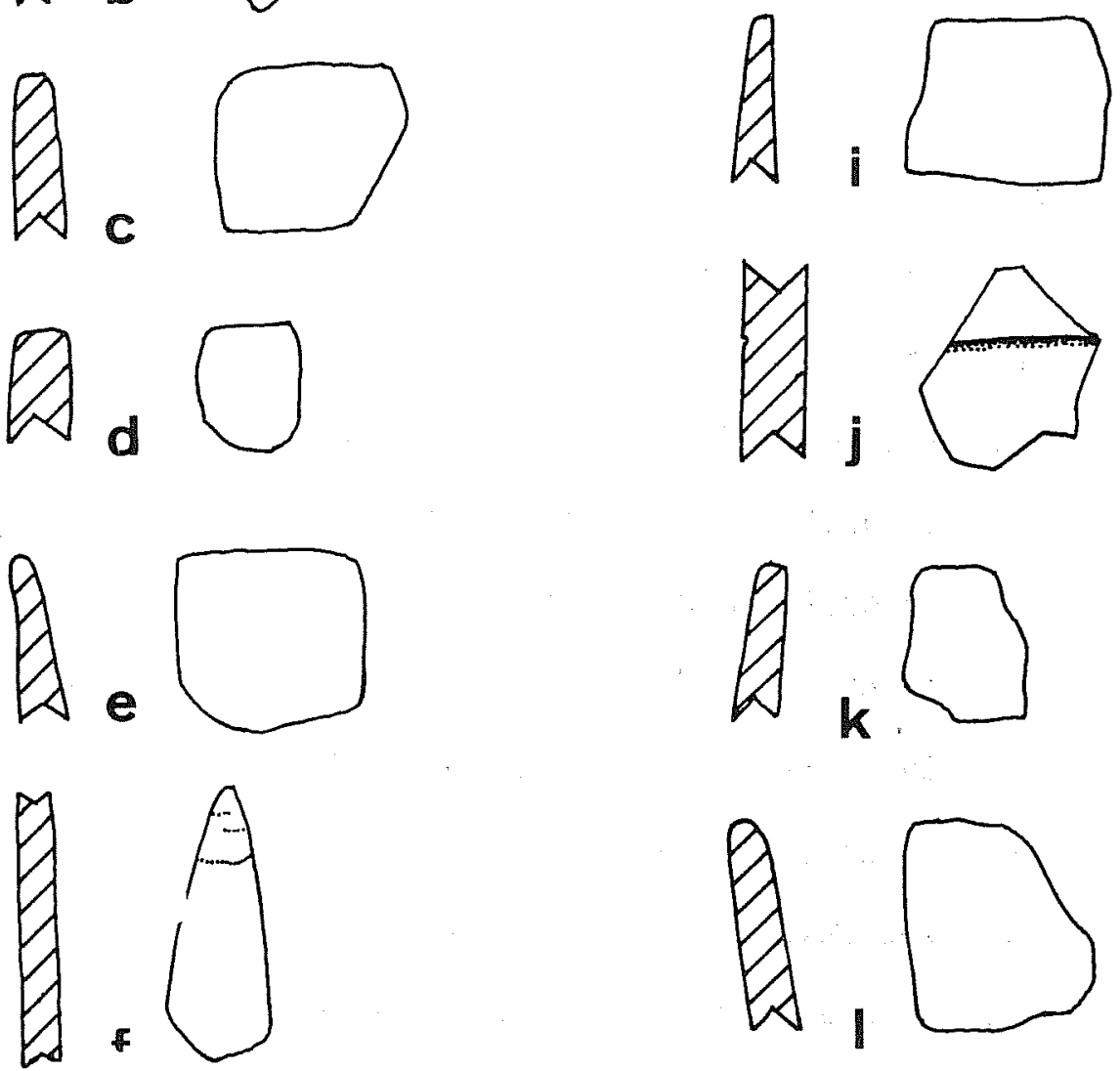

是, D
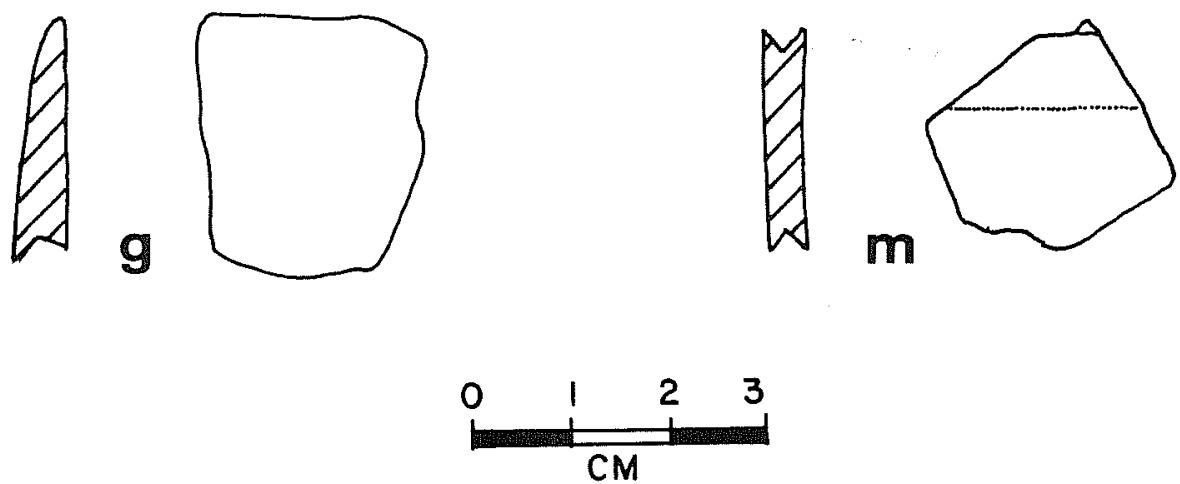
Figure 11. Sandy Paste Untempered Sherds from 41 LB 48.

a. incised body, unit 1 , level 2

b. incised body, unit 1 , leve 12

c. incised body, unit 1 , leve 12

d. decorated rim, unit 1 , level 3

e. decorated body, unit 1 , leve 3

f. punctated body, unit 1 , level 3

g. decorated rim, unit 1 , level 3

h. decorated body, unit 1 , level 4

i. decorated rim, unit 1 , Teve1 4

j. decorated body, unit 1 , level 4

k. decorated rim (both sides), unit 1 , level 4

1. rim, Test 2 

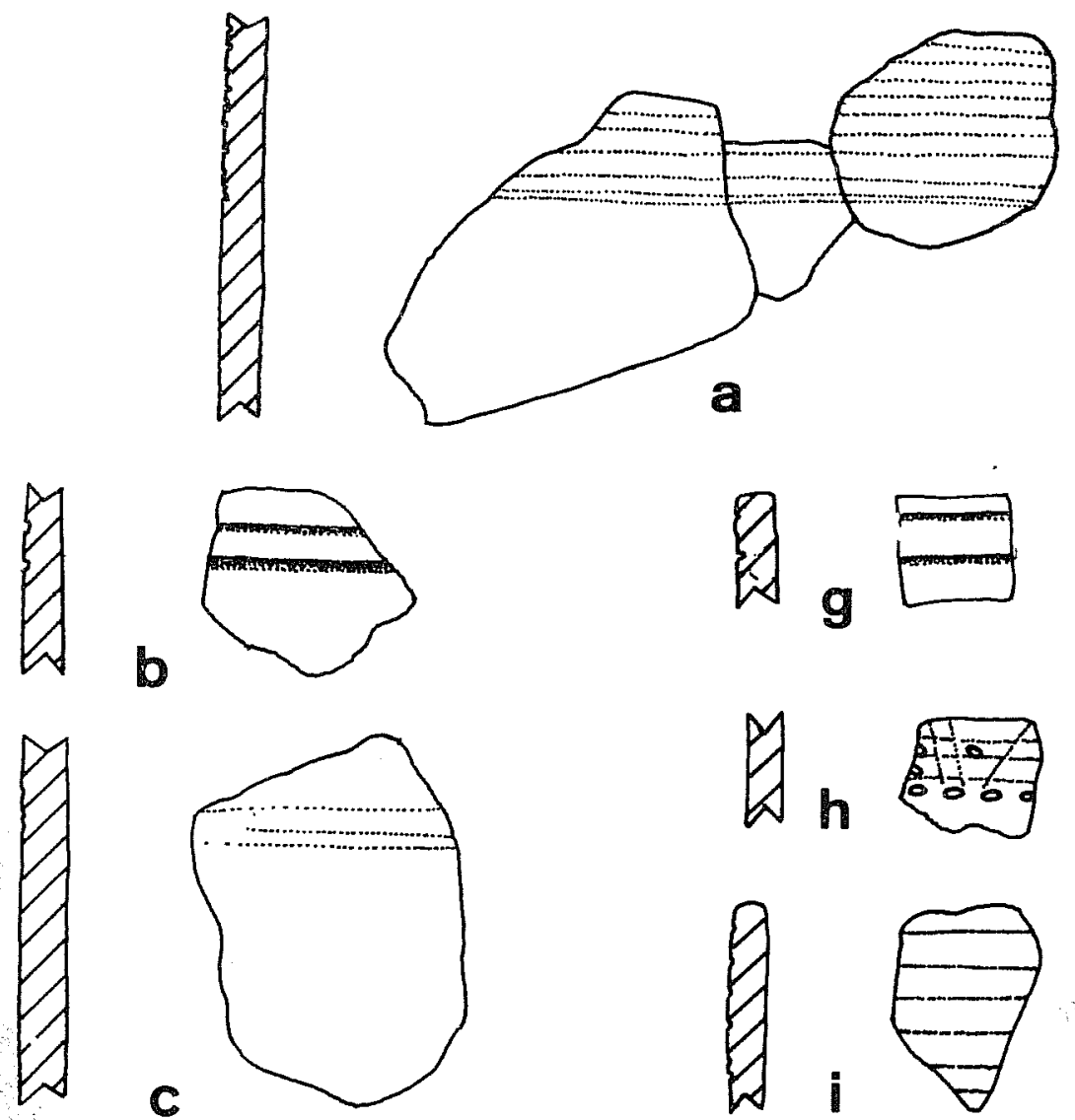

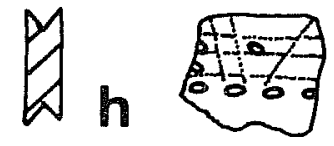
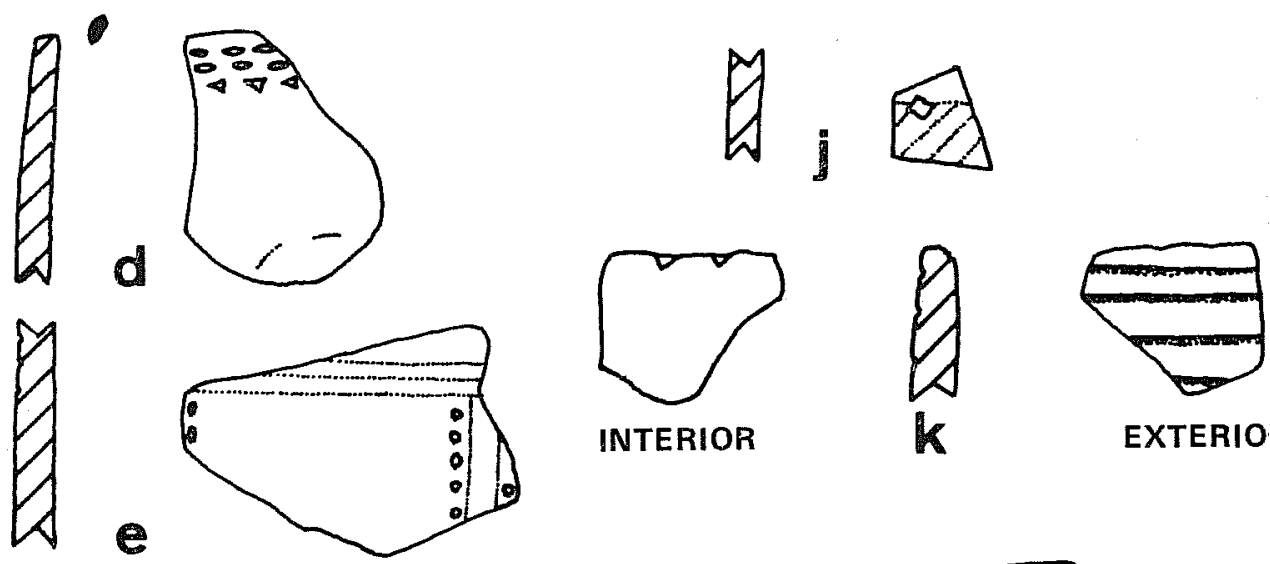

INTERIOR

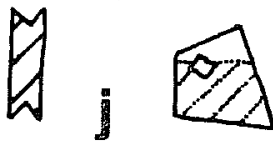

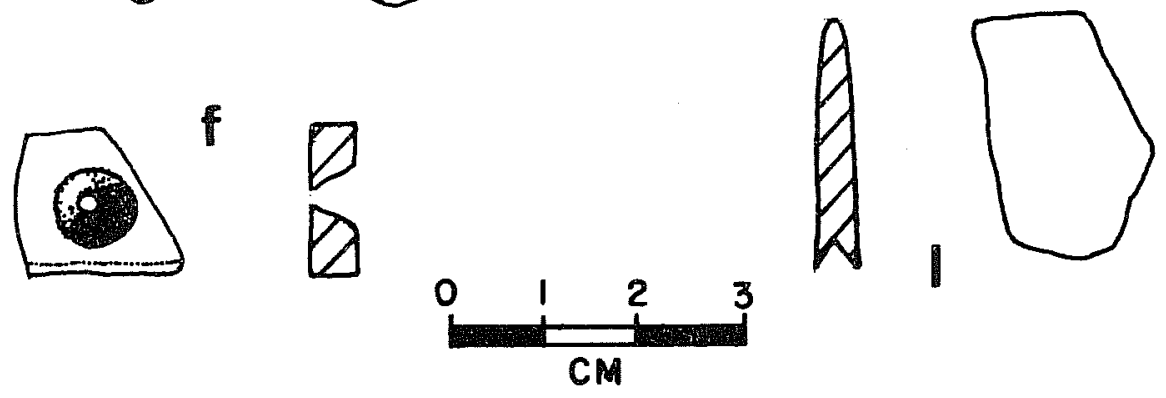



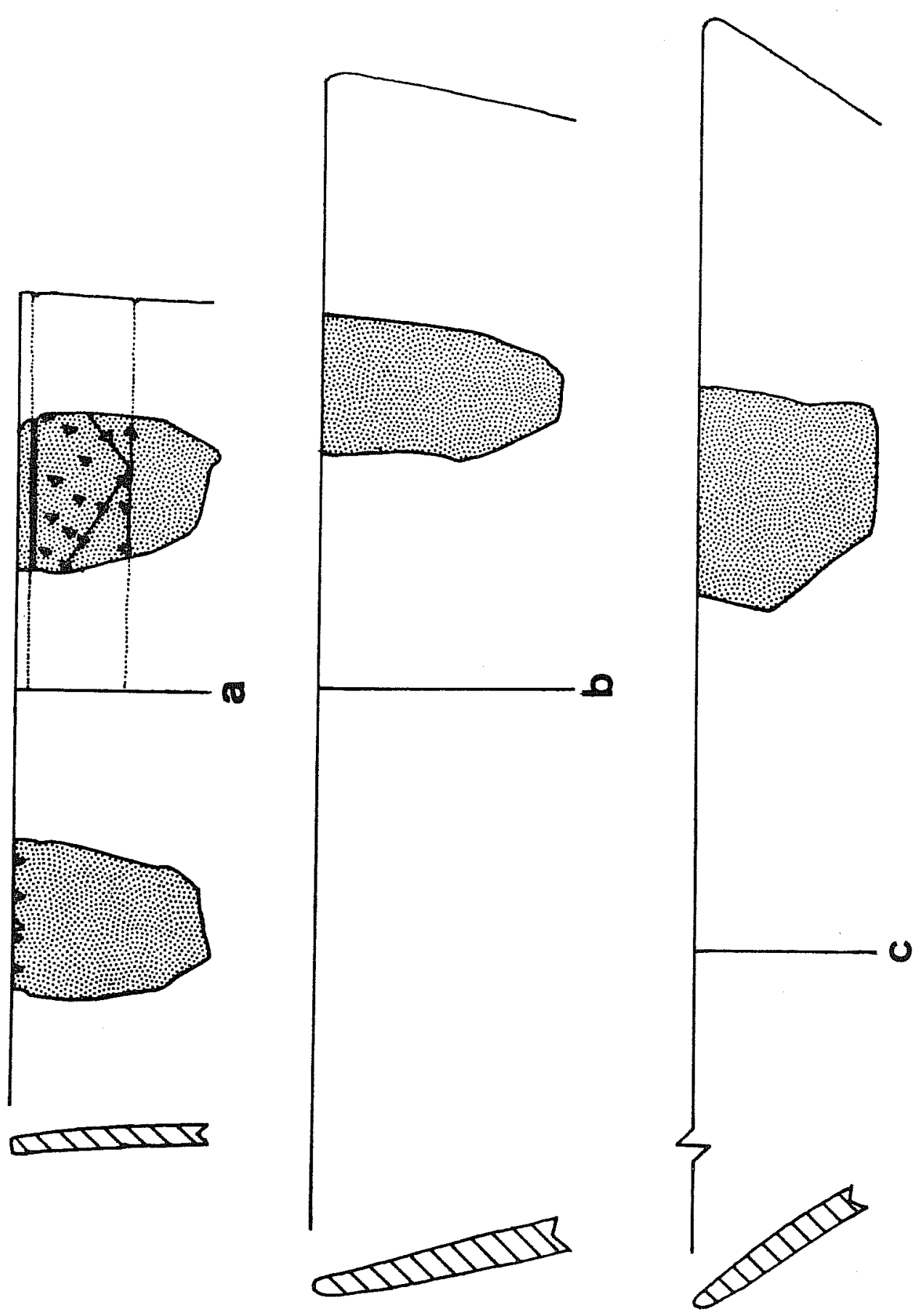

$\ddot{m}$

$\stackrel{1}{3}$

$-i$

峁

$\underbrace{n}$

엉

$\stackrel{9}{+}$

$\frac{\pi}{8}$

웜

ه

ro

(I)

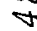

9

$\mp \dot{0}$

令亦

s-

ఫิ-

$\frac{\partial}{5}+$

도

ริ. हี

हूँ

棺

+

एक

드

त्ञ

유-

$+$

ن

$\rightarrow$

岁

مَ 


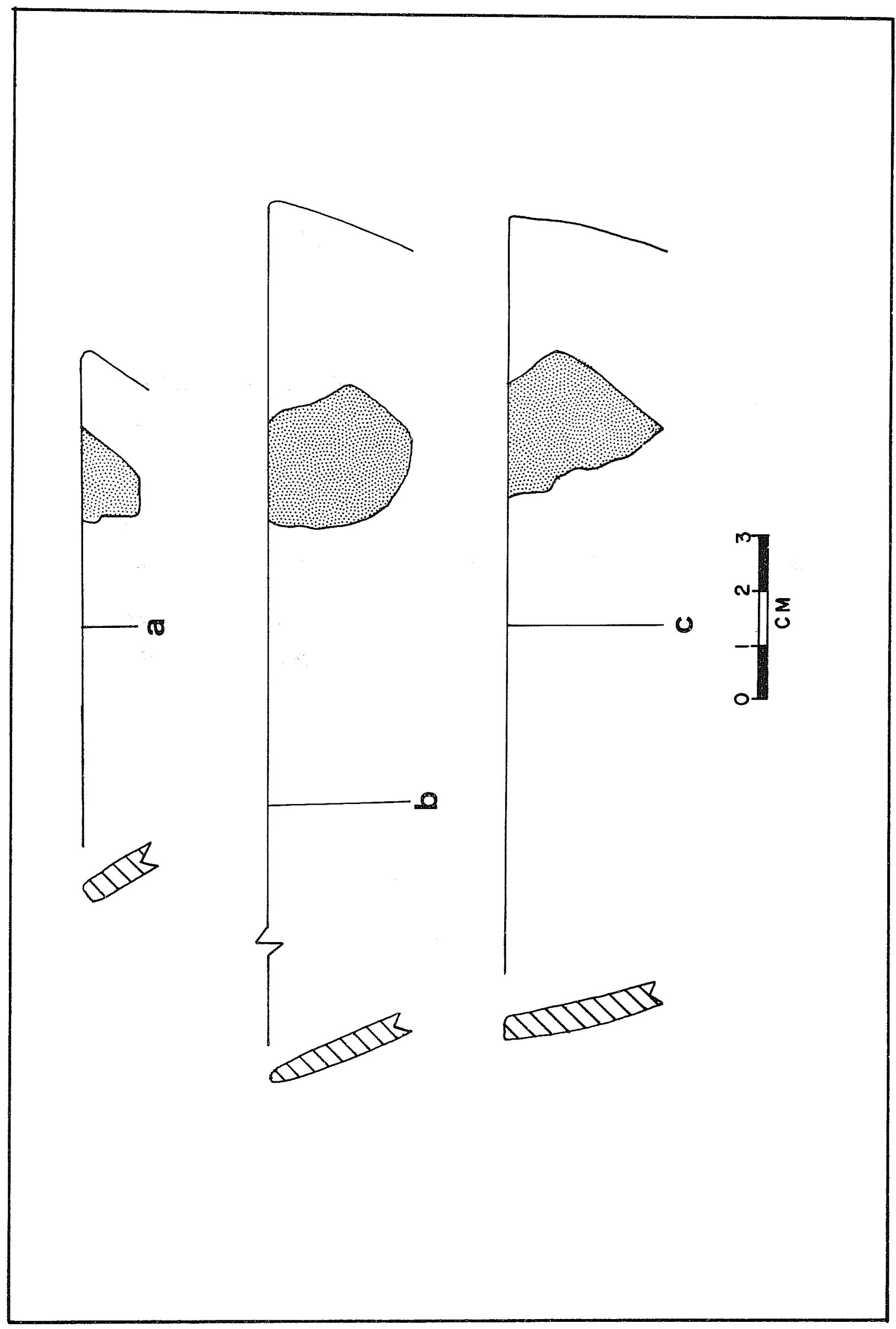


TABLE 6. SITE PROVENIENCE OF PREHISTORIC CERAMICS

\begin{tabular}{|c|c|c|c|c|c|c|}
\hline & Grog & Bone & Sand & $\begin{array}{c}\text { Clayey or } \\
\text { Silty }\end{array}$ & Sandy Paste & Total \\
\hline $41 \mathrm{CH} 22$ & 10 & & & & 31 & 41 \\
\hline $41 \mathrm{CH} 54$ & 4 & & & & 3 & 7 \\
\hline $41 \mathrm{CH} 57$ & 4 & & & & 37 & 41 \\
\hline $41 \mathrm{CH} 62$ & 66 & & 10 & 4 & 365 & 445 \\
\hline 41 LB 48 & 70 & & $\underline{6}$ & - & $\underline{405}$ & 481 \\
\hline Total & 154 & & 16 & 4 & 841 & 1015 \\
\hline
\end{tabular}




\section{HISTORY OF THE WALLISVILLE AREA}

\section{Introduction}

In the middle 18th century, Spanish Texas encompassed the eastern half of present-day Texas and a part of western Louisiana. By 1731 Spain, fearing the threat of French expansion across its eastern border, had established military posts and missions at strategic locations in the province of Texas. The capital of Texas, Los Adaes, was erected on the west bank of the Red River opposite the French settlement at Natchitoches. Other military posts and missions included Nacogdoches, San Antonio, and La Bahía (Fig. 14).

In 1745 rumors concerning active French trading in the lower Trinity River region prompted a sudden interest in a previously ignored portion of Texas. To curb French aggression, Presidio San Agustín de Ahumada was established on the lower Trinity River in 1756, and plans were made for a civil settlement. An accompanying mission, Nuestra Señora de la Luz, was established to serve the Orcoquisac Indians who lived along the lower San Jacinto and Trinity Rivers (Bolton 1970:325-374; Castañeda 1939:46-98).

The presidio and mission were abandoned in 1772 after a brief but stormy existence. The location of the site was an overriding factor in the failure of the project. The military personnel and religious instructors had to contend with a swampy, insect-infested region that caused constant medical problems and promised little in the way of agricultural possibilities. Natural calamities, such as floods and hurricanes, added to the frequent setbacks suffered by the establishment. The extreme isolation of the site resulted in a constant lack of supplies, including food, clothing, arms, and ammunition (Rader 1971:106).

Administrative incompetency created major problems between several governors and presidial commanders and caused dissension among the military personnel at the presidio. Added to this were the conflicting opinions of the missionaries regarding administrative policy (Rader 1971:108; Bolton 1970:364-372).

Because the proposed civil settlement never went beyond the planning stages, the presidio and mission lacked the manpower and skills necessary to maintain a sizable settlement. The failure to successfully institutionalize the Orcoquisacs also resulted in a lack of manpower and severely impeded the economic independence of the establishment ( $i b i d$.$) .$

A7though the presidio and mission were never reestablished, Spanish forces continued to occupy eastern Texas in the closing part of the 18th century. The United States replaced France as a threat to Spanish security, and efforts were made to repel aggressive expansion. While many Anglo-American settlers came to Texas in the early 1800s under authorized land grants, most entered illegally. In 1821 Mexico gained its independence from Spain and inherited the responsibility of repressing illegal immigration into Texas. The flood of immigrants continued, and the resulting political problems led to the Texas Revolution. 


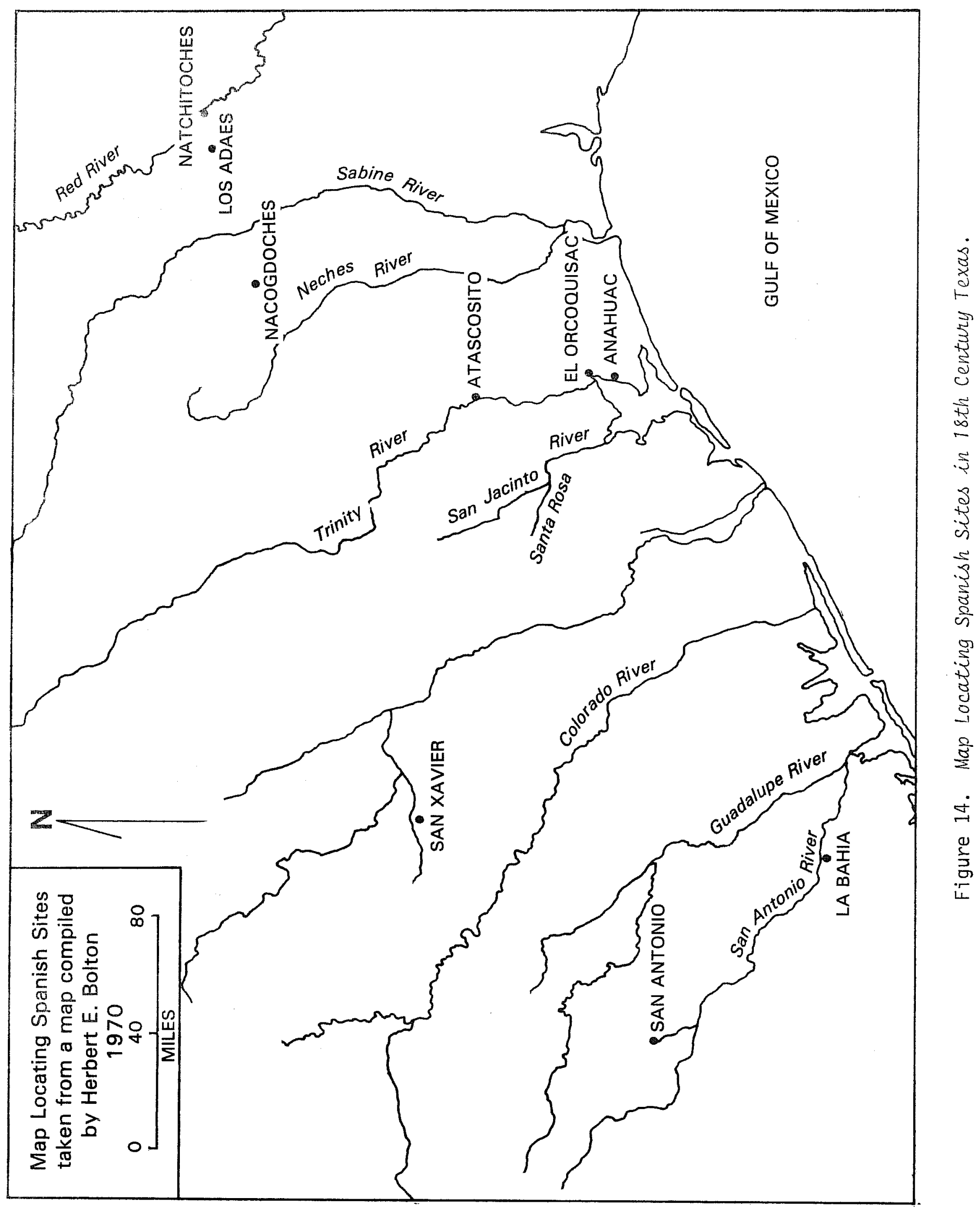


The Indians

When the Spanish entered the Trinity River region in the mid-1700s, they encountered several groups of Indians who were culturally similar, spoke a common language, and were interrelated by marriage. The Orcoquisac became the most well known of the Atakapans after Presidio San Agustín de Ahumada was established in their territory. Various insights regarding the Orcoquisacs were mentioned in numerous Spanish documents, and collectively they provide valuable information regarding the aboriginal lifestyle of the region.

The Orcoquisacs were related to several other groups of Atakapan-speakers. The Bidais lived north of the Orcoquisacs along the middle Trinity River and the upper San Jacinto River (Mayhal1 1939:97). Ethnohistorical accounts suggest strong cultural, social, and political ties to the Orcoquisacs. The Deodoses lived north of the Bidais, while the little-known Patiris lived in the San Jacinto River valley north of the Orcoquisacs (Newcomb 1961:316).

The Orcoquisacs were not agricultural but relied instead on fishing, hunting, and gathering for subsistence. They apparently lived in relatively permanent villages when not engaged in seasonal migration. Because of a better geographic location, the Bidais, Deodoses, and Patiris could practice agriculture. Hunting was also an important activity in their culture (Newcomb 1961:321,324).

The Orcoquisacs were divided into four or five groups, each with a chief. At the time of Spanish contact, the chiefs were Canos, El Gordo, Mateo, and Calzones Colorados. The Bidais were divided into several groups which may have totaled as many as seven separate bands. Antonio and Tomas were the onty Bidai chiefs mentioned by the Spaniards (Bolton 1970:332-336,341).

Additional aspects of the culture of the Orcoquisac and Bidai Indians are included in the following sections of this report.

The Spanish Era

In 1745 Don Joaquín de Orobio y Bazterra, captain of the presidio at La Bahía, wrote to the viceroy in Mexico concerning persistent rumors of French activities in Spanish territory along the lower Trinity River. In response, the viceroy ordered Orobio to explore the area to determine the extent of French aggression. If French subjects were encountered, Orobio was to order them out of Spanish territory. He was also ordered to gather information regarding the type and number of Indians along the lower Trinity (Bolton 1970:328). Orobio left La Bahía with 21 men on December 6, but due to the lack of geographical information regarding the eastern part of Texas, it was several months before he finally found a feasible route to the lower Trinity. In early January he arrived at the Spanish presidio at Nacogdoches and approached the lower Trinity from there. While at Nacogdoches, Orobio learned that 15 shipwrecked Frenchmen had recently passed through on their way from the coast to the French settlement at Natchitoches (Bolton 1970:329-330). 
Leaving on February 7, Orobio followed the Bidai trail made by the Bidai Indians from their territory to Nacogdoches. On March 6 he arrived at a place near the Trinity River in Bidai territory which he called Santa Rosa de Viterbo. Located at this site were seven Bidai rancherias. The Bidai Indians had never before seen Spaniards, but were quite familiar with French intruders. They reported that French traders came every year with trade goods such as guns, cloth, and knives. Some came by sea and entered the interior by way of the Trinity, Neches, or Brazos Rivers. Others came by land, including a group who for six years had been living with the Pachina Indians, whose territory extended from the Sabine River to the Mississippi River. Their trade network extended into Orcoquisac territory (Orobio y Bazterra 1745).

According to the Bidais, the French who came by boat had recently selected a site for a permanent settlement in Orcoquisac territory. An Orcoquisac messenger had been sent to the Bidais to tell them of the impending settlement, and the Bidais had relayed the information to neighboring Indians (ibid.).

Orobio then traveled 30 leagues southwest of Santa Rosa de Viterbo, and on March 15 he arrived at a place he called San Raphael which Bolton (1970:330) has identified as present-day Spring Creek. Located here were two Orcoquisac rancherias. Orobio presented gifts to the Orcoquisacs and termed them "docile." The Orcoquisacs said they had never before seen Spaniards, al though they were familiar with the French (Orobio y Bazterra 1745).

The French had not yet established their settlement, but the Orcoquisacs expected them to return in the summer. The French had asked them to contact the Bidai, Deodoses, and Tejas Indians to urge them to bring their deerskins, buffalo hides, and other items for trade once the post was established. The Orcoquisac chief reported that there were no French settlements among the Cocos, Cujanes, or Karankawas who lived southwest of their territory, but that one of three or four families did exist among the Pachina nation. Several Frenchmen had recently been lost among the Cujane tribe who lived southwest of the Orcoquisacs. Orobio surmised that the shipwrecked Frenchmen who had recently passed through Nacogdoches were probably part of a search party sent to rescue this lost group (ibid.).

On March 23 Orobio visited the proposed French site on the Nuestra Señora de Aranzazu (the present-day San Jacinto River). Orobio decided that the site lacked the natural resources necessary to build and maintain a sizable settlement. On April 6 he returned to La Bahia and reported the extent of French encroachment to the viceroy (Orobio y Bazterra 1745).

On May 3, 1747 and again on October 2, 1747, a group of Orcoquisacs journeyed to La Bahía and requested that a mission be established in their territory (Rader 1971:26). In January 1748 the viceroy ordered Orobio to explore the coastal region from the Guadalupe River to the Trinity River and to locate possible sites for a Spanish settlement. Additional information was also to be gathered on the Orcoquisacs (Castañeda 1939:49). 
On June 10 Orobio camped on the Trinity River about 15 leagues from its mouth. After the arrival of several Orcoquisac Indians in canoes, Orobio sent a message with them to their chief who was encamped at the mouth of the Trinity. Returning the following day with four canoes and many Indians, the chief insisted on taking Orobio back to his village in his canoe. The Spaniards camped near the village and distributed food, tobacco, and trinkets to the Orcoquisacs (Castañeda 1939:50-51).

Before returning to La Bahía, Orobio led a reconnaissance to the Sabine River. He also explored the coast near the mouth of the Trinity and found an area of recently cut timber. The Orcoquisacs explained that a small group of white men who were not French had come in several large boats, cut the timber, and then departed after several days. Orobio concluded that they were English. He returned to La Bahía on July 4 and reported his findings to the viceroy (ibid.).

After Orobio's initial visit to the lower Trinity area, the governor of Texas, Jacinto de Barrios y Jáuregui, devised an illegal trade network which extended into Bidai and Orcoquisac territory from 1751 to 1759. His personal agents included Marcos Ruiz, Domingo del Rio, Juan Antonio Maldonado, and Jacinto de Léon, who were soldiers stationed at Los Adaes (Castañeda 1939:52; Bolton 1970:336). The merchandise, including guns and ammunition, was purchased from the French at Natchitoches in direct violation of the viceroy's orders. In return for the European trade goods, the Indians traded horses, corn, and hides. The governor, using Spanish funds, purchased the corn and horses for the garrison from himself. The hides were either sold illegally at Natchitoches or shipped to Salti110, Mexico (Castañeda 1939:52-53; Rader 1971:28-29).

On September 20, 1754 Governor Barrios ordered Lieutenant Marcos Ruiz and a company of 25 men to inspect the lower Trinity region. Reliable reports to the governor indicated that four French traders and two Spaniards had come by canoe and were living in huts at the mouth of the Trinity. Ruiz was ordered to arrest the Frenchmen and take them to San Gabriel (Barrios $y$ Jáuregui 1754a).

Ruiz was sent on this mission because of the rapport he had established with the Bidai Indians through his activities as an agent for Barrios' trade operations. Barrios instructed Ruiz to take trade items to the Bidai and Orcoquisac Indians and to turn over to them all items confiscated from the French to insure their continued support of Spanish activities. Lastly, Ruiz was ordered to burn the landing and houses of the French (ibid.). The events that followed were later described in sworn statements given by Ruiz and several of his soldiers.

Not until reaching the Bidai village of chief Tomas did Ruiz tell his men the intent of the mission. Guns, ammunition, scissors, bells, and cloth were distributed to the Indians, who in turn eagerly agreed to participate in the proposed endeavor. Tomas asked for a horse that the lieutenant had planned to give to the governor. Because Bidai support was necessary to the success of their mission, he promised to give Tomas the horse if they succeeded in arresting the Frenchmen (Arias 1754; Cordova 1754). 
After leaving the Bidai village, they marched into Orcoquisac territory and gained additional support. Ruiz (1754), Cordova (1754), and Arias (1754) reported that they passed through two Orcoquisac villages, while del Rio (1754) mentioned three. De1 Rio reported that Tomas persuaded Mateo, chief of the first Orcoquisac village, to join them in the venture. Cordova (1754) reported that the second village was in sight of the mouth of the Trinity. The Orcoquisacs were given gifts, and by the time the combined forces reached the French site, the Spaniards had a total of 31 Indians with them (ibid.).

On October 10, 1754 Joseph BTancpain, Elias George, Antonio Dessars, and two Negro slaves, Bernardo and Joseph, were arrested without incident at their camp situated two leagues above the mouth of the Trinity. According to sworn statements by Ruiz and one of his soldiers, all confiscated trade goods were distributed to the Indians (Ruiz 1754; D. del Rio 1754). Most of the accounts reported that Blancpain's canoe or barge was sunk as ordered by the governor, but before the huts and other canoes could be burned, the Indians persuaded the Spaniards that they needed them (Arias 1754; Cordova 1754).

According to the Orcoquisacs, Blancpain had destroyed the commission given to Calzones Colorados by the Spaniards and had given a commission to Canos, one of the other Orcoquisac chiefs. Canos had recently traveled to New Orleans to meet with French officials. The Orcoquisacs also informed the Spanish that Lacreu, a French trader, had recently left Blancpain's camp to return to New Orleans for 50 French families waiting to settle in Texas. Ruiz told the Orcoquisacs to notify him if the settlers arrived and he would return and arrest them (ibid.).

After the completion of the campaign, Ruiz gave Tomas the horse he had requested at the onset of the expedition. Del Rio (1754) reported that Tomas and Mateo were responsible for the success of the venture. Del Rio stated that the location of Blancpain's camp would be ideal for a Spanish settlement. The Orcoquisacs had recently visited Spanish officials in Nacogdoches, San Xavier, San Antonio, and La Bahía and had requested that a mission be established for their nation. According to Arias (1754), "The river was of good sounding and very wide for navigation and that the Indians who live in those places are peaceful and very docile a1though addicted to thievery." Cordova (1754) concurred with this assessment of the Indian's character and stated that Mateo was the most intelligent and most inclined to Spanish endeavors.

After examining the facts presented in the soldiers' testimony, Governor Barrios urged the viceroy to estabiish a presidio at the mouth of the Trinity River to prevent further French incursions (Barrios y Jáuregui 1754b). He stressed the advantages of the location as a seaport:

The French are successful with their settlements because they always locate them on the banks of the large rivers. . . . A71 these (settlements) enjoy the advantages of navigation and can therefore export their products. . . The only purpose of our (settlement) is to reduce the infidels; but in this (settlement) . . it is possible to achieve both purposes and it is not too unreasonable to hope to establish a settlement that can be self supporting within a few years without the aid of a presidio (Barrios y Jáuregui 1754c). 
On February 19, 1755 Blancpain gave a sworn statement to the officials in Mexico City. Originally from Mons, Flanders, he was currently an Indian interpreter for the Louisiana government. Other enterprises included a mercantile store at Natchitoches and a farm located 22 leagues from New Orleans. Coming by boat from New Orleans, he had arrived at the lower Trinity on about August 1, 1754. Just prior to his arrest several others who had traveled with him had returned to Louisiana (Blancpain 1755).

Blancpain declared that he had come to trade on his own initiative, although he had the permission and Ticense of the governor of New Orleans. In answer to the charges against him, he denied trading with the Bidais or Orcoquisacs. His operations concerned the Atakapans only. French trade with this group of Indians had existed for 22 years, and he had been involved in the operation for 25 years. Five or six days prior to his arrest, these Indians warned him that the Spanish were coming. He and his companions did not try to escape because they believed they were in French territory (ibid.).

Blancpain was also charged with destroying the Spanish commission of Calzones Colorados. He denied this and claimed that he did not know the chief. He also denied granting a French commission to Canos. When questioned about Lacreu's activities, he denied that he had returned to New Orleans to bring back 50 French families. Blancpain's statement also included an inventory of the seized trade goods, and he claimed that the Spanish officer's inventories included only about one-fourth of the total amount confiscated. He stated that the goods were distributed among both the soldiers and the Indians with the bulk of the material going to the soldiers (Blancpain 1755). Statements by Elias George and Antonio Dessars supported Blancpain's sworn testimony. George added that 2,300 deerskins were seized by the soldiers, and that one of them, Diego Ramon, had sent two mule loads of goods to his brother (Castañeda 1939:60-61). He also testified that Domingo del Rio took 10 packs to Los Adaes, while two pack loads were sent to San Antonio (Rader 1971:33).

Blancpain died in a Mexican prison on February 5, 1756 (Amarillas 1756). His companions were taken to Spain and imprisoned for 1ife. The king of Spain ordered that any other Frenchmen found illegally in Spanish territory be arrested and imprisoned on an island off the coast of South America (Arriaga 1757).

On April 29, 1755 Barrios ordered Domingo del Rio to return to the lower Trinity to determine if Lacreu had returned with the French settlers. Domingo and his brother, Cristobal, were included in the expedition because they, like Ruiz, were agents of Barrios' trade operations and were popular with the Indians of that region. To insure continued cooperation from the Indians, del Rio took with him 25 pounds of red and blue beads, loin cloths, powder, balls, ribbons, cloth, tobacco, and combs. He also carried a commission for Mateo, as well as a gold-trimmed red coat and hat, a shirt, and a cane. According to Barrios, Tomas, the Bidai chief, had previously received a commission and a cane (Barrios y Jáuregui 1755).

The company of Spaniards then marched to the Orcoquisac village, whose chief was El Gordo. From there they sent for Mateo, described as the "Big Chief" of the Orcoquisacs. He arrived after four or five days with 15 Indians from 
his village. He was given a commission, coat, hat, and other items. When questioned about French activities in the area following the arrest of Blancpain, the chief reported that several Frenchmen had come by boat and had sailed as far as the Brazos River. Shortly thereafter, four Frenchmen came on horseback with many trade items (D. del Rio 1755).

This French activity caused the Indians along the coast to withdraw to the village of El Gordo "fearing the abuses which (would occur) after Captain Canos came" (ibid.). Canos had been appointed "Big Chief" by Blancpain and Lacreu and, as a result, was we 11 dressed and received many gifts from the French. The Orcoquisacs claimed that only Canos and his followers supported the French endeavors. Mateo, probably in an attempt to reassure the Spanish of his loyalty to them and to impress upon them the power he possessed, stated:

. . the (French) only have the favor of Captain Canos and his kinsmen but that al1 (others) are affectionate toward the Spaniards and that they do not abandon their loyalty to .Captain Mateo whom they obey absolutely and that with regard to Captain Canos, he renders homage to Mateo because of his great power and esteem among the Orcoquisacs. ... (C. del Rio 1755).

Tomas and Mateo also requested a meeting with the "Captain Grande of the Spaniards" to express their gratitude for the gifts he had sent them and to again request a mission for their nations. They and 17 other Indians returned to the presidio at Los Adaes with del Rio and his company (Cordova 1755; C. del Rio 1755).

On February 12, 1756 the new viceroy of Mexico, the Marques de 1as Amari1las, ordered the immediate occupation of the lower Trinity to forestall further French encroachment into Spanish territory. The site of Blancpain's post was to be occupied by a lieutenant with a company of 30 soldiers. The soldiers, whose military service was to last six years, would remain in the settlement as colonists. A mission to serve both the Bidais and Orcoquisacs was to be established concurrently with the presidio. The initial location of the presidio and mission was to be temporary. After an adequate site for the proposed civil settlement was established and functioning, the presidio and mission would be reestablished near the colony (Amarillas 1756).

On July 12, 1756 Governor Barrios wrote to the viceroy regarding the orders to establish the presidio and mission on the lower Trinity. Under the command of Lieutenant Marcos Ruiz, 30 soldiers left Los Adaes on May 16 with horses, cattle, oxen, arms and ammunition, equipment, and supplies. The presidio was established on May 26 on the site of Blancpain's camp and was named San Agustin de Ahumada in honor of the viceroy, Don Agustin de Ahumada Villalon Mendoza y Narvez, Marques de las Amarillas. By July 12 temporary structures were erected and corn had been planted. Barrios reported that he was gathering trade goods to be used by the Spanish to persuade the Indians to enter the mission (Barrios y Jáuregui 1756a).

In the latter part of 1756, Fray Bruno Chavira and Fray Marcos Satereyn arrived at El Orcoquisac and established the mission of Nuestra Señora de la Luz. Barrios did not approve of the two missionaries, stating that Fray Chavira 
was too old while Fray Satereyn was too young and inexperienced. Before Barrios could have them removed by royal decree, Chavira died and Satereyn left temporarily due to illness (Castañeda 1939:73).

Barrios ordered Father Fray José Francisco Caro to visit the mission and submit a report. Fray Caro vividiy described the unhealthy conditions at El Orcoquisac to his superior, who in turn wrote to Barrios:

The mosquitos and flies have produced such unutterable hardships that he does not want to live in this state of misery. . . . The place is unhealthy for it is very marshy and without drinking water. . . it does not have hills for protection in winter--living in this climate has resulted in the deaths of the Most Reverend Padre Lector Fray Bruno Chavira and Majordomo Julian Flores of San Miguel and in the sickness of Fray Marcos Satereyn. . Most of the presidio is saddened by the painful flux of blood which took the said Reverend Lector Minister. These attacks are preceded by much bad water which. . . becomes salty in running from the south. Even without this movement the water of the nearby lake is very bad for it is muddy and stagnant (Vallejo 1758).

Fray Caro asked to be removed from the mission. If this was not possible, he strongly urged that the mission be moved to a more habitable place called El Atascosito several miles north of the present mission location. The move was never authorized, and Fray Caro was replaced by Fray Abad de Jesus Maria (Castañeda 1939:75).

In August 1756 Barrios ordered Lieutenant Domingo del Rio and Don Bernardo. de Miranda to conduct a reconnaissance of the surrounding areas and locate a suitable site for the civil colony (Barrios y Jáuregui 1756b). Two and one-half Teagues north of the presidio were three arroyos. Del Rio's account states that Calzones Colorado's rancheria was located on the middle stream (del Rio 1756). Traveling west by canoe they reached the San Jacinto River, which they judged to be 12 leagues from the Trinity River (Miranda 1756).

Del Rio and Miranda agreed that a western branch of the San Jacinto called the Springs of Santa Rosa (present-day Spring Creek) offered the most suitable location for a colony. Located on the Santa Rosa was the village of Canos, who was described by del Rio as the "Big Chief of the Orcoquisacs." By this time Canos had temporarily revoked his allegiance to the French because he emphasized his desire for a Spanish mission. Miranda reported that Canos' village consisted of 20 warriors with their families. He did not know how many Indians were in Calzones Colorados' band because they had visited only one of the two villages under his command. El Gordo, Mateo, and Antonio had villages nearby (ibid.)

In April 1757 Miranda added additional knowledge about the Springs of Santa Rosa. They were located in the center of the Orcoquisac nation, which consisted of five villages or rancherias. Miranda, however, had visited only 
four of the five villages. Mateo's village was located above the Santa Rosa. El Gordo's village was along the shore of Santa Rosa, while Canos' village was near the junction of the Santa Rosa and the San Jacinto River. The village of Calzones Colorados was on the Trinity River (Miranda 1757).

On January 7, 1757, the authorities in Mexico approved the removal of the presidio and mission, commonly referred to as El Orcoquisac, to the site selected on the Springs of Santa Rosa. The followers of Calzones Colorados, Canos, and "others" were part of the mission system at El Orcoquisac, and they were to be moved to the new site (Amarillas 1757). Bolton (1970:351) and Castañeda (1939:78) both state that the site was near the village of El Gordo. It was hoped that Mateo and his followers and the nearby Bidais could be persuaded to settle in the new mission (Amarillas 1757).

Elaborate plans for the civil settlement had been formulated since the viceroy's initial decree in 1756, but the civil settlement never got beyond the planning stages. Many factors were responsible, but the major one was the inability to find 50 families willing to go to a remote frontier settlement. The inability to select a suitable site for the civil settlement added to the failure of the project (Rader 1971:48-50). Several sites other than Santa Rosa were suggested, but a firm decision was never reached. On February 3, 1758 government officials in Mexico recommended that no further action be taken regarding the establishment of a civil colony at El Orcoquisac (Castañeda 1939:85).

On February 6, 1759 Don Angel Martos y Navarrete replaced Barrios as governor of Texas. Determined to find a new site for the presidio and mission, he traveled to the proposed sites in October. Ruling out Santa Rosa and El Atascosito, he favored both Los Horconsitos and Los Pielagos which were located north of El Orcoquisac. Martos reported that three Orcoquisac chiefs had settled near the mission but had not yet committed themselves to mission life. Tomas, described as the general of the Bidais and Orcoquisacs, had recently told Domingo del Rio that he intended to enter the mission at El Orcoquisac. He and his followers had been delayed because it was their custom to eat "roasting ears" with "El Texas" in August. An Atakapa chief visited with Martos and said that his entire nation and the Apelusa nation were preparing to enter the Orcoquisac mission. The governor also reported that Blancpain's boat had almost rotted away and had no anchor or ropes (Martos y Navarrete 1759). Fray Abad, opposed to the removal of the establishment to either one of the governor-proposed sites, wrote to the viceroy concerning the problems and the advantages of E1 Orcoquisac (Bolton 1970:355; Castañeda 1939: 86-87). First of a11, he suggested that a new commander for the presidio be appointed to replace Domingo del Rio in order to improve the morale and efficiency of the garrison (Clay 1977:13). In defending the location, he reported that the mission had recently been moved a short distance from the presidio and was showing progress. The location, comparable to other suggested sites, was described by the missionary:

- . we did not find any place more suitable or nearer the presidio than a hill, something less than a fourth of a league's distance to the east from the latter and on the same bank of the lagoon. This place, Excellent Sir, because of its elevation, commands a view of the whole site of the presidio and of a 
circumference to the west and south, where this River land is a little less elevated. . . the mission was erected on this site. It is made of wood, all hewn, and beaten clay mixed with moss, and has four arched portals (Bolton 1970:349).

Fray Abad added that the Indians would object to such a move, since the nearby bay provided a variety of food sources which they skillfully exploited. The mission settlement was beginning to function with buildings erected and crops planted. Fray Abad also reported rumors of recent French activities in the area. Despite the reasoning of Fray Abad, the governor recommended that the mission and presidio be moved to Los Horconsitos. The viceroy complied and issued the formal decree on March 15, 1759. The move, however, never took place (Bolton 1970:355-356).

On Apri1 29, 1763 Domingo del Rio, commander of the presidio, complained to the viceroy about the deteriorating conditions at El Orcoquisac. The garrison was in dire need of food, clothing, and ammunition. Blaming the governor for the deplorable conditions, del Rio suggested that the presidio be removed from the governor's jurisdiction and that the commander of the post be directly responsible to the viceroy (Castañeda 1939:87; Bolton 1970:367).

On November 23, 1763 Raphael Martínez Pacheco was ordered to replace Domingo del Rio. Pacheco arrived at El Orcoquisac on May 13, 1764. A7though Timited information is available regarding mission progress between 1759 and 1763, it is apparent that little had been accomplished regarding missionization of the Orcoquisacs. Pacheco, aware of the lack of control over the native population, considered the failure of the Orcoquisacs to accept and support mission life the most urgent problem to be dealt with at El Orcoquisac. On May 14 he gathered 155 Orcoquisacs and urged them to enter the mission. Speaking through the interpreter, Domingo del Rio, he explained to Calzones Colorados and the others the requirements of mission life. The Indians were expected to live within the mission compound and to obey the instructions of the king, his soldiers, and the missionaries. Permission to leave the mission was required, and if they violated any of the rules they would be punished by the commander or by Indians appointed to special positions. They were to attend daily prayer services, work in the fields, and help defend the presidio and mission against the French and hostile Indians. Pacheco, probably at the urgings of the missionaries, told the Indians that they must give up their gourd whistles and other ceremonial items. If they accepted mission life, they would receive adequate clothing and four head of cattle each week. The Indians eagerly agreed to all of the stipulations (Pacheco 1764a).

On May 31 Canos requested permission to enter the presidio with a group of Atakapa Indians. They entered carrying the French flag but promptly turned it over to Pacheco. Canos wanted to talk privately with Calzones Colorados to verify reports that the Orcoquisacs were receiving excellent treatment at the mission (Pacheco 1764b). After observing daily mission activities, Canos was impressed and requested a separate mission for his followers (Pacheco 1764c).

On June 6 Tomas and two other chiefs of the Bidais arrived with 48 Indians. Tomas expressed friendly feelings with regard to the Spanish and requested 
that a mission be established in Bidai territory. He also asked for meat, corn, and tobacco "because they had great need" (Pacheco 1764c).

On June 14 Pacheco wrote to the viceroy concerning progress at El Orcoquisac. Additional funds were necessary to rebuild the deteriorating presidio and mission structures and to purchase needed supplies (Bolton 1970:366). Providing for the Indians' we1l-being was expensive, and Pacheco reported that he had spent 1,000 pesos on clothing and had provided them with two beeves and ten bushels of corn per week (Castañeda 1939:89). Pacheco also recommended that separate missions be established for the villages of Canos and Tomas (Bolton 1970:366).

Governor Martos did not approve of Pacheco's appointment, and in June he journeyed to El Orcoquisac to enforce and supervise the move to Los Horconsitos. The intense situation of the two opposing factions ended when both the missionaries and the Indians supported Pacheco by objecting to the move. The governor's visit lasted a month, and during that time he must have added to the $i 11$ feelings that were brewing within the military framework at the presidio (Castañeda 1939:90).

While providing for the Indians in a fatherly fashion, Pacheco was apparently excessively brutal to the soldiers. By August 28 all but five of the soldiers had deserted to Natchitoches. In a letter to Governor Martos concerning the circumstances of their desertion, the soldiers described in detail the physical assaults by Pacheco against several soldiers at San Agustín de Ahumada. They also related previous acts of irrational behavior by Pacheco at San Antonio, San Sabá, Coahuila, and Salti110. According to the deserters, the missionaries and Indians were also preparing to leave El Orcoquisac (Cordova et al 1764).

On September 12 Governor Martos ordered Lieutenant Marcos Ruiz to arrest Pacheco and replace him as commander of the post. Ruiz took 22 soldiers with him, including the deserters who had been exonerated by the governor. As they approached the presidio on October 7, they saw Pacheco standing on the pier (Ruiz 1764). He ran to his quarters, which he had prepared for a possible siege. He had the two cannons from the presidio as well as numerous firearms and large quantities of ammunition (Bustamante 1764). Three soldiers joined him against the forces of Ruiz.

Ruiz read the governor's order but Pacheco refused to submit, claiming he was responsible only to the king. A scuffle ensued and one of Ruiz's men was killed. Pacheco called upon the Orcoquisacs and Atakapas for help, and they attacked the soldiers, although there were no reported injuries or casualties.

Because Domingo del Rio was away from the post and there was no one else to parley with the Indians, Ruiz and his company retreated (Ruiz 1764). After de1 Rio's return he agreed to try to persuade the Indians to oppose Pacheco. The Indians asked for three days to convince Pacheco to surrender. If after three days Pacheco still refused to surrender, the Indians would then support Ruiz (Bolton 1970:369). 
For three days Calzones Colorados, Fray Salvino, Lorenzo Bustamante, and one of the women at the post, Rosa Guerra, tried to persuade Pacheco to surrender (Villa Fuerte 1764). Pacheco refused. Finally, on October 11, Ruiz set fire to Pacheco's quarters. In the resulting confusion Pacheco and Ambrosio Brioso escaped through a secret door in the chimney. Ruiz reported that an empty barracks and part of the church also burned (Ruiz et al 1764).

Pacheco and Brioso were given refuge for several nights at La Bahía. Pacheco then traveled to Mission San José at San Antonio, where he was arrested but was allowed to move about freely (Castañeda 1939:92). He eventually traveled to Mexico, where he was imprisoned (Bolton 1970:371).

Marcos Ruiz took charge of San Agustin de Ahumada and investigated the charges against Pacheco. Calzones Colorados admitted that he had been bribed by Pacheco to oppose the removal of the presidio and mission to Los Horconsitos. Del Rio was implicated and subsequently arrested by Afan de Rivera, who was named commander of the post in May 1765. Del Rio was charged with "insubordination, disrespect and poor conduct" (Rivera 1766). In November Ruiz was arrested for burning the presidio. In 1767 charges were filed against Governor Martos for the burning of the presidio. His trial lasted 14 years, and he was assessed a heavy fine (Bolton 1970:372).

The closing years of El Orcoquisac were also plagued with misfortune. On September 4, 1766 a hurricane destroyed all of the supplies and severely damaged most of the buildings. Afan de Rivera asked the viceroy for permission to move the presidio to higher ground. The viceroy replied that such a move had been authorized since December 9, 1762. Rivera reportedly moved the presidio to a low hill a quarter of a league from its original site (Castañeda 1939:94).

In 1767 Marques de Rubi, an officer from Spain, and Don Nicolas de la Fora visited El Orcoquisac while on an inspection of Texas. Rubi's opinion of the importance of Presidio San Agustín de Ahumada and Mission Nuestra Señora de la Luz was not favorable:

I therefore consider this presidio useless, for it does not serve to support the missions, which are absolved by the slight inclination of those natives to embrace our sacred religion, a fact which has been well experienced since the year 1758, when the only one there is was founded without accomplishing in all this time the reduction of a single Indian . . . for it is a very unhealthful place, in the midst of lagoons which make impossible communication with any other of our settlements. Here, by a bad arrangement, those unfortunates are obliged to sustain themselves the greater part of the year on some roots called camotes, on nisperos, nuts, cherries, some chestnuts smaller than those of Spain, and other equally wild foods (Rubi 1768).

Rubi also detailed the lack of adequate military equipment (ibid.). Louisiana had been ceded to Spain by France in 1762, and Rubi declared that the presidio was no longer needed since the French threat no Ionger existed (Castañeda 1939: 95). 
In September 1769 an exonerated Pacheco replaced Rivera as commander of the post. Pacheco had been tried and found innocent of all charges against him. His administration was marked by reconstruction and reform. Fray Anselmo Garcia and Fray Ignacio Maria Lava praised Pacheco's endeavors. From September 1769 to September 1770 he provided food, clothing, and other supplies at his own expense. He also summoned a doctor for the presidio and paid for his services. In October 1769 he helped transport 125 shipwrecked families to Natchitoches. They signed sworn statements attesting to his kindness (Castañeda 1939:96-98).

In summer 1770 the governor of Texas, Baron de Ripperda, asked Pacheco to send part of his garrison to help defend San Antonio against hostile Indians. In September 1771 he was required to send the remainder of his men to San Antonio. He left three soldiers with the missionaries to guard the mission, but they too left within several weeks of Pacheco's departure (Castañeda 1939:98).

Although the presidio and mission at El Orcoquisac were abandoned in 1772, the lower Trinity River region continued to be the focal point for activities aimed at halting foreign aggression. On November 30, 1803 Spain returned Louisiana to France. Within a month the United States purchased Louisiana from France. The United States was viewed as an imminent threat to Spanish control of Texas, and plans were formulated to establish military posts and colonies in the lower Trinity region and the areas toward the Sabine River to curtail immigration or aggression (Clay 1977:87-91).

In 1805 Governor Antonio Cordero ordered 50 soldiers under the command of Sergeant Urrutia to El Orcoquisac to halt illegal activities in that area. Smuggling was rife, and horse herds were being driven to Louisiana. Urrutia was also ordered to arrest $i l l e g a l$ immigrants, seize all vessels carrying settlers or contraband cargo, and to erect a stockade. After inspecting the El Orcoquisac area, Urrutia rejected it as a viable location and established the post at a spring called Atascosito (near present-day Liberty). He reported that the site was a more favorable spot for the horses and more accessible to the road which led to the Atakapa and Apelusa tribes in Louisiana (Salcedo 1805). Within a few months Captain Geronimo Herrera established a garrison at Atascosito. Three other companies were stationed at Trinidad located at Spanish Bluff on the east bank of the Trinity River (Clay 1977:91-92).

During the first decade of the 19th century, numerous requests were made to the Spanish government for permission to settle the area of Nacogdoches, Atascosito, and El Orcoquisac. Texas land was cheap and plentiful compared to that of the United States, and large numbers of settlers were ready to take advantage of the situation. While many permits were granted, few authorized colonies were established. In 1806 the Spanish government officially closed El Orcoquisac and Atascosito to settlement. In 1808 reports reached Spanish officials that despite the 1806 law many English and French colonists had settled in the area (Clay 1977:95-97).

In January 1818, 400 French exiles sought refuge in Texas. Under the command of Charles Lallemand and Antoine Rigaud, the colonists obtained boats and supplies from Jean Laffite, the pirate who controlled the port of Galveston. They established a civil colony and military fort called Champ d'Asile on the lower Trinity River, probably near present-day Liberty (John Clay, personal 
communication). During the latter part of 1818, friendly Indians warned the settlers that Spanish forces were en route to remove them from Spanish territory, and the settlers retreated to Galveston Island. A devastating hurricane struck and killed many of the colonists. Laffite, seeking to be rid of the French settlers, gave the survivors a ship so they could escape to New Orleans (Clay 1977:106-111; Webb 1952:378). On October 29, 1818 the Spanish troops arrived at the abandoned French fortress and destroyed it (Castañeda 1818).

The Mexican Era

On September 28, 1820 the Spanish government decreed that New Spain would accept colonists if certain requirements were met. In July 1821 Texas and Mexico became independent of Spain, causing confusion regarding immigration procedures. In 1823 Stephen $F$. Austin was granted a contract by the Mexican government to bring 300 families into Texas (Webb 1952:82). The Colonization Law of 1824 allowed acquisition of land through an empresario, but in 1830 a new law was passed prohibiting American colonization of Texas (Clay 1977:119-125).

Prior to the 1830 law, empresarios Joseph Vehlein, David G. Burnett, and Lorenzo de Zavala had received grants of land comprising the area between the San Jacinto River and the Sabine River. Unable to financially support the endeavor, Vehlein transferred his contract, which included the present-day Wallisville area, to the Galveston Bay and Texas Land Company. After the passage of the 1830 immigration law, the Mexican government refused to recognize the land company and the grants it possessed (Burch 1950:109-113). In 1833 the 1830 law was repealed, and the Galveston Bay and Texas Land Company was allowed to proceed with colonization activities (Harry 1940:13).

In 1826 a census was compiled which listed 331 settlers living in the Atascosito area. The census, which included the E. H. R. Wallis family, was sent to Stephen $F$. Austin with a request that he incorporate the Atascosito district into his colony (Osburn 1963:301). In the eastern part of Texas, an effective judicial system had not yet been established, and the early settlers had not yet received land titles. Austin had been named land commissioner of his colony by the Mexican government, which allowed him to grant land titles to his colonists. He also possessed broad civil, judicial, and military powers. The benefits of an alliance with Austin's colony would provide the Atascosito settlers with legal ownership of land as well as judicial and military protection. The eastern settlement, however, was never authorized to join Austin's colony (Clay 1977:123-124).

Elisha Henry Robert Wallis, originally from Burke County, Georgia, moved to Louisiana, where he married Sarah (Sa11y) Barrow in 1814 (Fleischman 1976:214). In the latter part of 1824, the Wallis family journeyed to Texas with Sally's three brothers, Solomon, Reuben, and Benjamin Barrow. In the first week of January 1825 the Wallis family settled at a site just east of present-day Wallisville. Originally known as Wallis Hill, the early homesite became a popular way station for travelers. On an 1837 map drawn by Austin, the settlement was identified as "Wa11ace" (Harry 1940:23-24). 
In 1830 a military post and customs house was established at Anahuac to support the Taw passed on April 6 of that year which prohibited American settlers from colonizing Texas. Colonel Juan Davis Bradburn, the commander of the post, was to use his garrison to control the flow of immigrants into east Texas and to protect the coast from Point Bolivar to the Sabine River. Land titles were to be negotiated through Bradburn (Clay 1977:126).

Bradburn, originaliy from Kentucky, was viewed by the settlers as a tyrant, and his actions added to the growing resentment against Mexican authority. In January 1831, José Francisco Madero, Land Commissioner for the State of Texas, arrived in Anahuac to grant land titles to the settlers along the lower Trinity River region and in the area between the Nacogdoches and Sabine Rivers. Bradburn, much to the dismay of the colonists, refused to allow Madero to issue the titles and arrested him for violating the law of April 6, 1830. After considerable political squabbling, Madero was finally allowed to issue 66 titles between March 2 and May 12, 1831, and on May 2, 1832 he granted three other titles (Clay 1977:133-134).

Bradburn continued to antagonize the settlers. He pressed supplies for his garrison and used slaves to build military structures without compensating their owners (Barker 1965:112). In 1832 he arrested several colonists, including Patrick C. Jack and William Barret Travis. Texas colonists from Brazoria, San Felipe, and the Neches and Sabine areas joined together to protest the arrests. The men were eventually released, and Bradburn was replaced by Juan Cortina. Bradburn defected to New Orleans to avoid Santa Ana's regime. The garrison abandoned Anahuac and sailed to Vera Cruz to join Santa Ana (Harry 1940:14-17).

In January 1835 Santa Ana began his campaign to control Texas, and Mexican military forces reestablished Fort Anahuac. Once again Texas colonists rebelled against Mexican authority, and the Mexican forces were driven out of the area (ibid.).

Several Texans from the lower Trinity River area took an active part in the subsequent Texas Revolution, including Andrew Briscoe, Dr. N. D. Labadie, and E. H. R. Wallis's son-in-1aw, James Dunman (Harry 1940:11,19). After the Battle of San Jacinto, General Santa Ana was held prisoner for a short time at the home of Wallis.

\section{Recent History}

On August 2, 1858 Chambers County was organized, and Wallisville became the county seat. In 1859 it was granted its first post office, and by 1876 had a population of 200. In 1907 the county seat was moved to Anahuac (Partlow 1974: 145). 


\section{HISTORIC SITES INVESTIGATIONS}

For purposes of clarity, the historic sites are grouped into the original land grants, surveys, or districts in which they lie. In no case should the historical background of a particular site be considered complete and exhaustive, but we believe the facts presented are accurate. The intent here is merely to identify and trace the essential history of site ownership in order that later historical researchers have a place to begin their work. (For location of historic sites see Fig. 15.)

MCMANUS SURVEY: 41 LB 49, MCMANUS LANDING

\section{History of the McManus Survey}

In 1832 Robert Oson William McManus came to Texas with a letter of introduction to Stephen F. Austin. He found work as a surveyor for several early East Texas empresarios. In 1836 he joined the Texas Army and was assigned as a spy for Henry W. Karnes' Cavalry Company. After the battle of San Jacinto, he was awarded 320 acres of 7 and for his army service (La Grange Journal 1940:6). In 1838 he married Sarah Isabella Spinks and settled on the Trinity River in the vicinity of Moss Bluff. By 1850 he had five children and had added 95 acres to his original grant (U.S. Census 1850). About this time McManus acquired a fleet of boats with which he transported goods and passengers up and down the Trinity River (La Grange Journal 1940:6). The following 10 years saw significant gains in the fortune of the McManus family, and by 1860 they owned 30,100 acres of land worth $\$ 13,000$ (U.S. Census 1860).

Numerous descendants of R. O.W. McManus still live in the area north of Lake Charlotte.

McManus Landing, 41 LB 49 (O1d Fisher Place)

This site was first located by studying an old map of the Trinity River which shows steamboat landings and "plantations" as of 1873 (Howe11 and Adams 1873). Partlow (1974:199), in her history of Liberty County, also mentions McManus Landing as a steamboat stop on the river. A 1928 Corps of Engineers map still refers to the area as the McManus Farm, although in 1930 the actual site is called the "old Fisher Place" (Work 1930). Over the years the latter name has been gradual1y adopted; the 1961 USGS quadrangle map (Shiloh) refers to the general area as Fisher Bend, and the McManus name is no longer preserved except in the name of Mac Lake and Mac's Bayou which drain the area to the east of the site.

The site is located on a slight rise at a bend in the Trinity River, 4-3/4 miles upstream from the IH-10 bridge. It is in the tract of land originally granted to R. 0. W. McManus.

\section{Archaeological Investigation}

The area was reached by boat and examined carefully on foot by the crew. At the time of the survey, the site was swampy and overgrown with brush. A slight 
This page has been

redacted because it

contains restricted

information. 
elevation at the location where the Fisher house is indicated on the map (Work 1930) supports a number of unusually large trees. Animal burrows in the area yielded a collection of late 19th century and early 20th century artifacts. Al1 artifacts visible on the surface were collected, and the area was inspected for traces of a structure. None were found, except for a few scattered, broken fragments of local1y made brick.

\section{Observations}

Frequent flooding of the area has eliminated or covered all traces of structures, which might have included the McManus dock, sheds, or other supporting buildings as well as the Fisher house and barn and other farm buildings from that occupation. Local residents noted the house in ruins when camping and fishing on the site in the early 1900s (Octavia La Four, personal communication) but apparently no trace was then visible of the McManus steamboat landing.

The artifacts collected (Fig. 16) are all representative of the Fisher occupation at the turn of the century when yellow-ware bowls and Bristol-glazed crocks and jars were popular. The presence of the locally made brick supports a date of approximately 1880 for the construction of the house. (See brick kiln sites below.)

\section{Recommendations}

While this is an interesting example of a 19th-century occupation site, there is no particular historical or structural reason to suggest its adequacy for nomination to the National Register. Periodic flooding has already done as much damage as can be done, and further inundation caused by the reservoir will probably serve only to cover what scant evidence is left.

\section{MCFADDIN SURVEY: $41 \mathrm{CH}$ 232, BRICK KILN AND $41 \mathrm{CH}$ 233, MCFADDIN MARKER}

These sites are located near the J. D. McManus home between Lake Charlotte and Lake Charlotte Road on the north shore of the lake. They are within the original James McFaddin survey.

\section{History of the McFaddin Survey}

The early history of the north shore of Lake Charlotte is complex and most difficult to unravel due to the burning of courthouses in both Liberty and Chambers Counties in the 1870s. A combination of family interviews, county tax rolls, and U.S. Census reports have been used to produce the following chronology, against which the archaeological sites can be understood and interpreted.

One of the earliest 7 andowners in the area was James McFaddin, who arrived in Atascosito in 1822 (Partlow 1974:65). In 1831 McFaddin was granted a tract of 1and north of Lake Charlotte (ibid.:75). In 1845, upon the death of their father, James, the four McFaddin heirs divided the Lake Charlotte land evenly among them (JCLR 1845:E317). 
Figure 16. Artifacts from $41 L B 49$, McManus Landing.*

a. flown blue transfer pattern on ironstone plate, probably 1880-1890

b. ironstone pitcher fragment, late 19th century molded design

c. white earthenware cup handle, late 19th century design

d. yellow-ware mixing bowl, late 1800s and early 1900s (Raycraft 1975:Plate 16)

e. lavender bottle base, no marks, snap case device, 1857-1903 (Lorrain 1968:40-43)

f. stoneware crock or churn with Bristol glaze, after 1900

g. olive green wine bottle neck, late 19th century

* All specimens shown actual size 


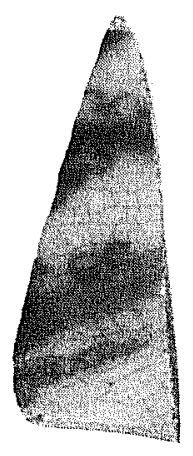

a

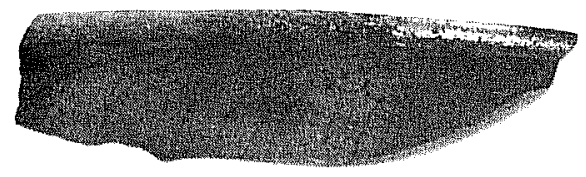

d

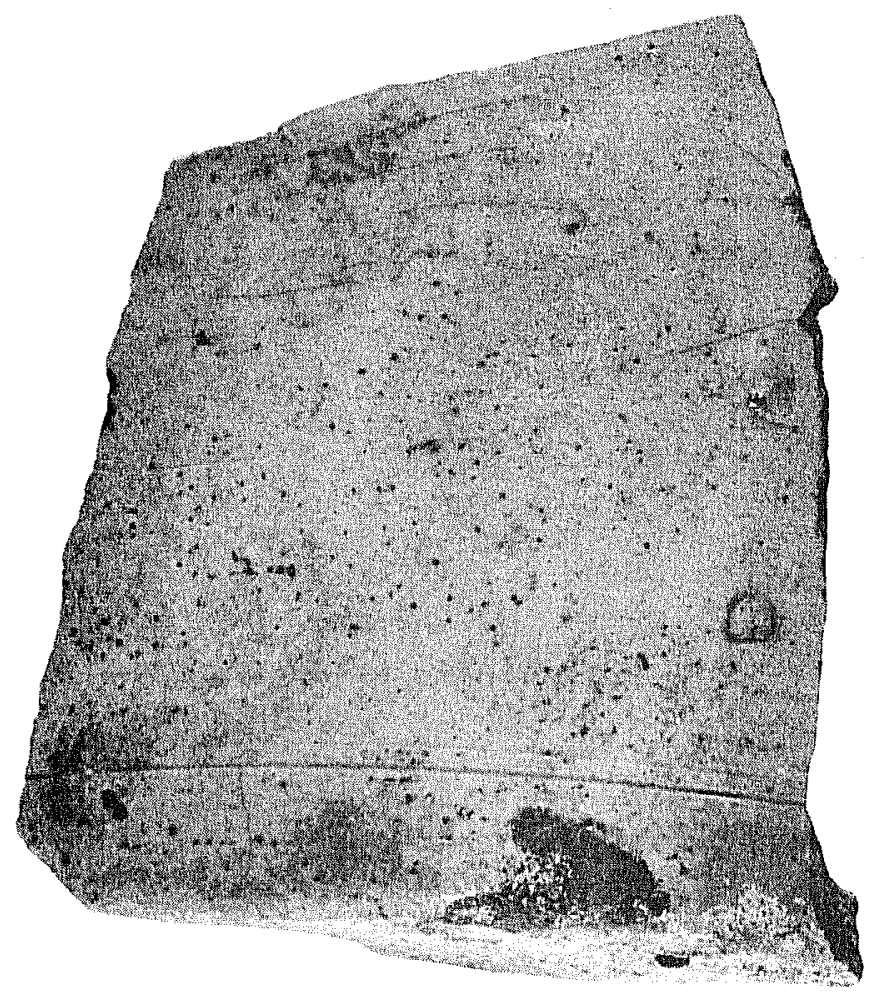

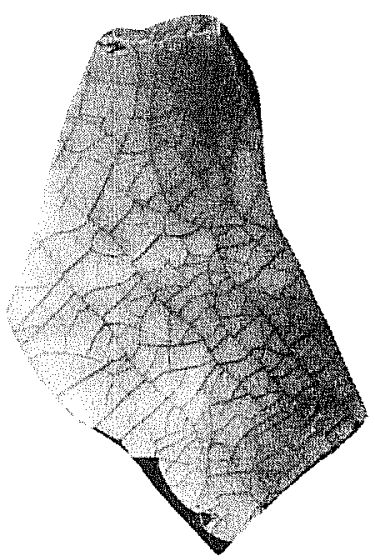

b

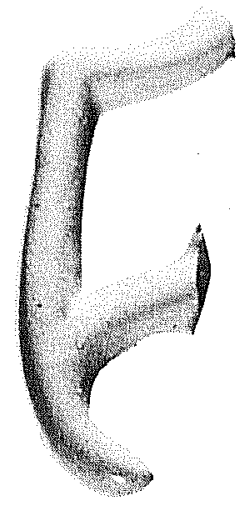

C

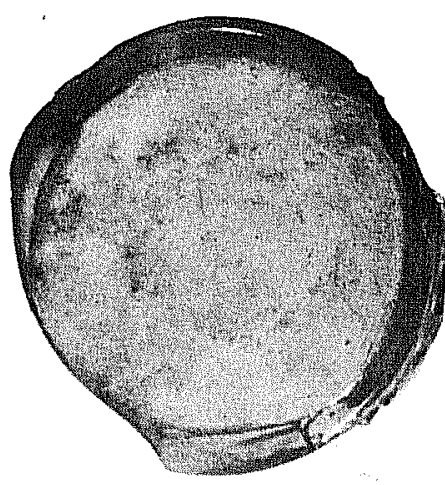

e

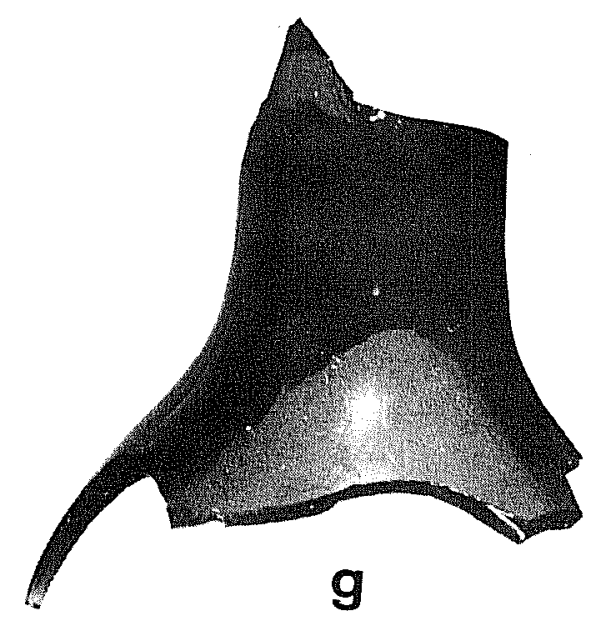


In 1847 Shadrack Jones and family were first 7 isted on the tax rolls (LCTR 1847) as owning 1,107 acres in the James McFaddin survey. A warranty deed dated February 25, 1848, and filed in 1884 (CCDR 1884:D189), records Jones' purchase of two lots totaling 1,025 acres from David McFaddin and his sister, Eliza Sishon. The 1850 tax rolls (LCTR 1850) list David McFaddin as owning 540 acres in the James McFaddin survey on which he ran stock but did not farm. In this same year, Shadrack Jones is listed as having 1,027 acres in the William McFaddin survey. (The reason for the change in the name of the survey is unclear, but evidently it was changed at this time, and James' name is not mentioned again.)

Shadrack Jones evidently died in 1851 or 1852, as the family property was divided among his three sons, Shadrack, James, and Miller, by 1853. David McFaddin apparently sold out his interest in the survey in 1852 to Shadrack $M$. Jones (LCTR 1852). By 1860 there are no McFaddins listed in Chambers County, and the Jones' Chambers County property is evenly divided between Miller and James Jones (U.S. Census 1860, Chambers County). At this point, Chambers County had been newly created out of part of Liberty County. The county line ran through the Jones property (the old McFaddin survey), apparently dividing the property of James and Miller on the south from that of Shadrack on the north, since Shadrack was listed from then on in the Liberty County census (U.S. Census 1860, Liberty County).

A portion of the Jones family property in Chambers County was referred to subsequently as the "01d J. J. Jones homestead." Mr. Jones died in 1871 (CCDR 1905:S196). The homestead was sold in 1885 by his daughter to $H$. C. Carter, who sold it in 1887 to Paul W. Sherman (CCDR 1887:F299-300). Since the Paul Sherman home was located well back from the edge of the lake on the north side of Lake Charlotte Road (Romain Sherman and George Munger, personal communication), it appears that any late 19th-century structures located on Corps of Engineers property on the lake would probably be connected with the Jones family's occupation.

Archaeological Investigation of $41 \mathrm{CH} 232$, Brick $\mathrm{Ki}$ in

The existence of an unidentified "pile of bricks" some distance behind the J. D. McManus residence was called to the survey crew's attention by Dennis and David McManus. The site consisted of a horseshoe-shaped mound of jumbled, broken bricks, slightly higher on the edges and lower in the center. The McManus family told of removing bricks from this pile for road building for a number of years. No one in the family had any idea where the bricks came from or why they were there.

Careful observation of the mound revealed a row of stacked bricks which was cleaned off until it was possible to tell the alignment of the row. Another similar row could be seen, ca. 20 inches to the north of and parallel to the first row. The bricks measured a uniform $4^{\prime \prime} \times 8-3 / 4^{\prime \prime} \times 2-1 / 2^{\prime \prime}$ and were poorly fired, breaking easily. Color ranged from a pinkish tan to dark gray. Five sides of each brick showed the striations and sharp edges of being pressed in a wooden mold; the sixth was roughly smoothed. There was no mortar between them. 
A two-foot wide trench was excavated north-south, perpendicular to these rows. As excavation progressed, an additional row of bricks was uncovered to the south which differed in pattern of arrangement. Further excavation revealed a line of unfired bricks along the south side of this row. A hand-forged nail was found against the base of the south row on the inside of the kiln (Fig. 17). Outside, or south, of the unfired bricks was a mixture of crumbled and broken bricks mixed with soil; this deposit continued to the edge of the mound. No mortar was present in this row. The presence of the unburned brick on the outside of the row confirmed that this was a kiln, rather than merely a stockpile, since Martin (Appendix I) says the local kilns were built of unburned bricks and that the outside layer generally dried but did not burn.

A trench was then excavated to the east, perpendicular to the first trench, to look for remains of the east wall of the kiln (Fig. 18). A machine-cut nail was found while excavating this trench. At the end of a row of stacked brick was found a single row which carried across the openings between the rows and formed a thin barrier or wall. On top of and to the east of this row were groups of bricks which appeared to be collapsed arches. However, the bricks were too jumbled and broken to attempt a reconstruction of this wal1.

The bottom layer of bricks rested on dark brown to black sand. Since the natural soil in the area is a tan sandy loam, it appears that the area was merely scraped level and the green bricks stacked on this surface, the walls of the kiln resting on the same surface as the rows of bricks to be fired. From the configuration of the south wall brick pattern, it appears that the walls of the kiln began to arch inward from a point approximately two feet from the bottom of the outer wa11. There were not enough courses of brick left on the south wall to determine the arc of the curve.

\section{Observations and Conclusions}

This kiln closely resembles those described as in use on Cedar Bayou in the last half of the 19th century. However, its size (ca. 18 feet square with a capacity of perhaps 15,000 to 20,000 bricks) suggests that it was a sma11scale undertaking which could have been run by one family for its own use and that of its immediate neighbors. The average mid-19th-century farmhouse in the area had one or two chimneys and sat on brick piers, requiring perhaps a maximum of 5,000 bricks for its construction.

It seems likely that the kiln was built by members of the Jones family sometime around 1852, since at that time they would have been building new homes on their recently acquired property. It would have been more economical to make brick on the place than to haul it in by boat from the kilns on Cedar Bayou.

\section{Recommendations}

Located toward the upper end of the proposed reservoir and at an elevation of 20 feet above sea level, the kiln is not threatened by flooding or construction activity. As a rather unique example of an early industry conducted in the 
Figure 17. Artifacts from McFaddin Grant Sites.*

$41 \mathrm{CH} 232$ Brick Kiln:

a. hand wrought nail, probably mid-19th century

b. machine-cut nai1, 1830 s to ca. 1900

$41 \mathrm{CH} 233$ McFaddin Marker Site:

c. ironstone plate with partial makers mark, not identifiable

d. ironstone plate, probably post-Civil War

e. hand-tooled bottle neck, snap case, 1857-1903 (Lorrain 1968:40-43)

f. hand-tooled bottle neck, see above

g. cast iron fragment

h. stoneware bowl with Albany slip and salt glaze, ca. 1870-1900

* A11 specimens shown actual size 

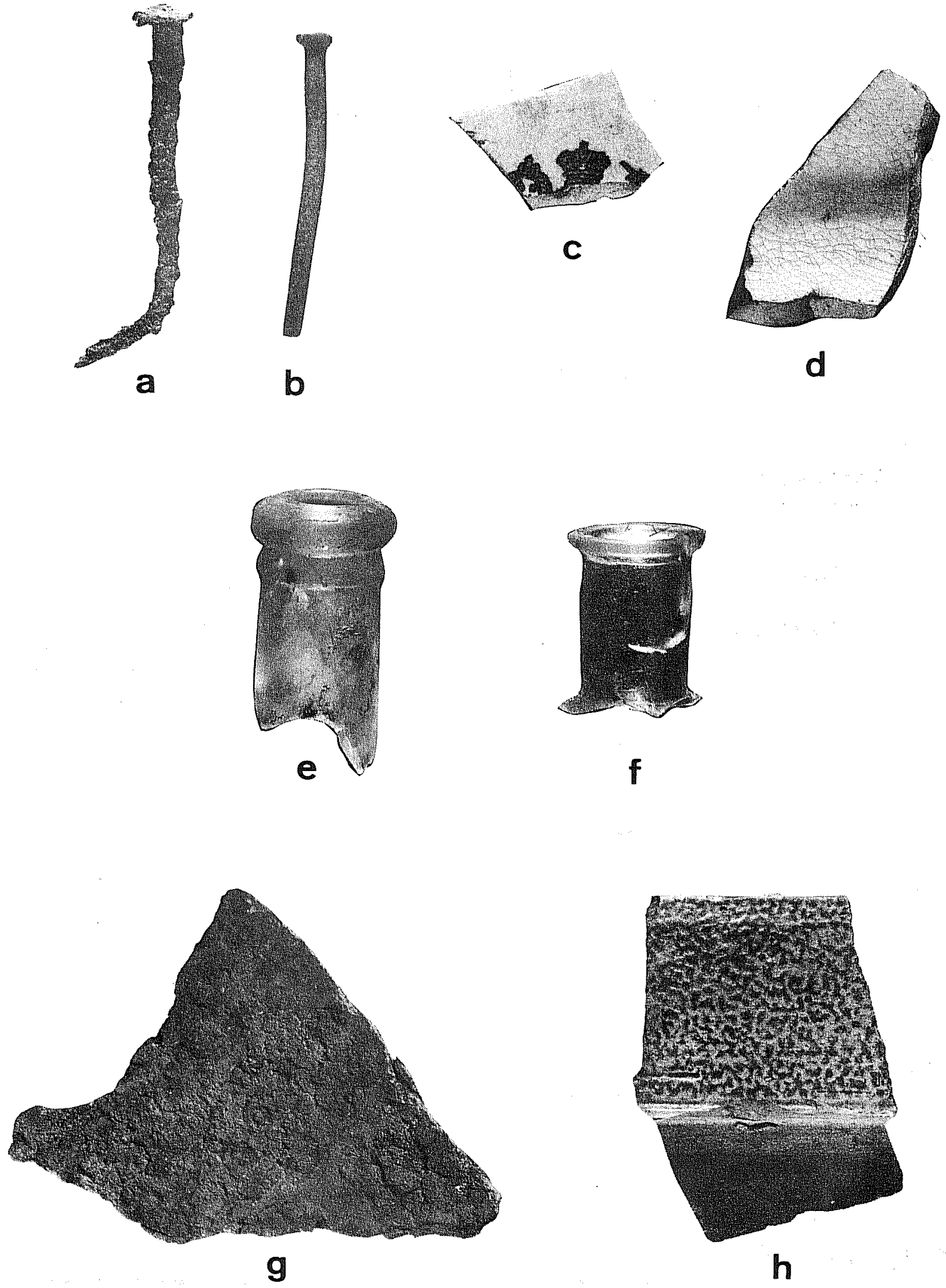


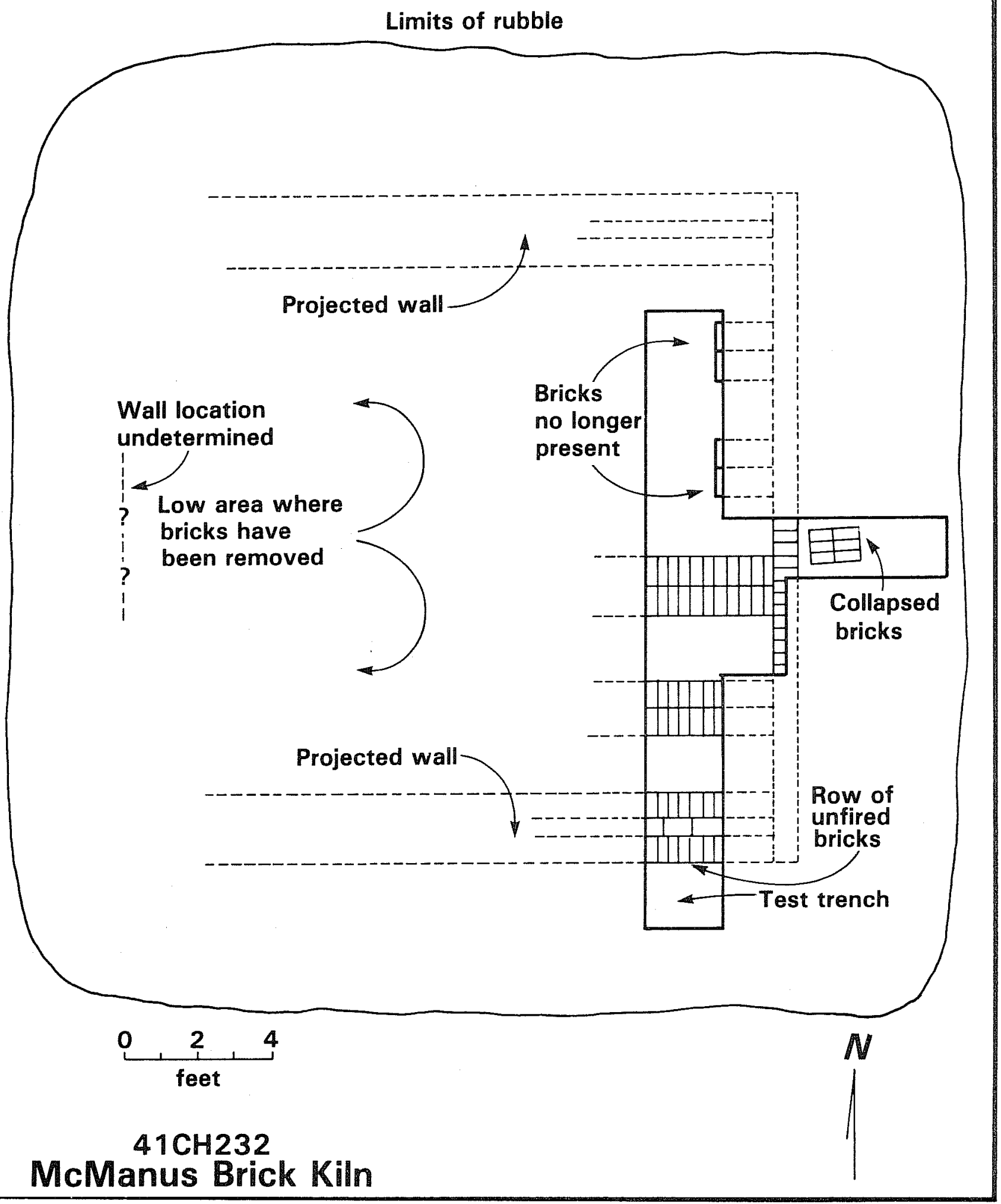

Figure 18. Map of Site $41 \mathrm{CH} 232$, McManus Brick Kiln. 
area, it would be of considerable interest to researchers and should be preserved in its present state and protected from further disturbance. Future, more detailed archaeological excavations should be able to establish its exact dimensions and the methods of construction and utilization of the structure. We recommend its nomination to the National Register.

\section{McFaddin Marker, $41 \mathrm{CH} 233$}

Dennis and David McManus guided the crew to the location of a granite marker erected in 1956 on the occasion of the Liberty Bicentennial, commemorating the original homestead of James McFadden (also spelled McFaddin in some places; for the sake of consistency in this report we use the latter spelling). The marker was placed in this particular spot because it was known to be an old house site (Joyce Calhoon, personal communication). The McManus boys reported having found square nails in the vicinity.

\section{Archaeological Investigation}

The marker is located ca. 40 meters from the edge of the bluff. The site is overgrown with dense underbrush and trees, and the ground is covered with a thick layer of dead leaves. An intensive surface examination of the area revealed no apparent concentrations of artifacts, nor were there any traces of structural remains anywhere in the vicinity. A thin scattering of Rangia shell was observed in the area of the site toward the lake, an indication of the presence of site $41 \mathrm{CH} 70$ along the edge of the bluff to the southwest (see Fig. 1 and Table 1).

\section{observations and conclusions}

A number of large trees stand on the site. The few scattered artifacts recovered indicate a date of occupation sometime after the Civil War. Judging from the reconstruction of the ownership of this piece of property, it seems likely that this was the site of the James J. Jones homestead. This would also account for the fact that the location of the house and outbuildings were remembered but the structures were gone by 1956, since the place was probably deserted or only minimally used after 1887 when Paul Sherman bought the property. If this was also the site of the original James McFaddin home, no confirmation is presently visible on the surface. It seems likely that McFaddin would have settled in a more easily accessible spot on the bank of the Trinity River in 1831.

\section{Recommendations}

More detailed archival research and intensive archaeology could probably establish whether this site is indeed the spot where James McFaddin built his home. The site is located sufficiently high (20 feet) and far back from the water to protect it from flooding, and it is not endangered by any known construction. 


\section{LABADIE SURVEY: $41 \mathrm{CH}$ 62, LABADIE SITE AND $41 \mathrm{CH}$ 234, MUNGER SITE}

These sites are located on the N. D. Labadie survey on the northeast shore of Lake Charlotte within an area proposed for a public park. The former site was reported to the crew by $W$. L. Futlen, who conducted the senior author on a tour of the site previous to the start of the survey. The second site was discovered during a boat survey of Lake Charlotte.

History of the N. D. Labadie Survey

Born in Canada in 1802, Nicolas D. Labadie studied medicine in St. Louis, Missouri while clerking in a store to earn enough to pay his expenses. In 1831 he arrived at Anahuac and was appointed surgeon of the Mexican garrison by Col. Bradburn. He immediately saw the possibilities in the mercantile trade in this rapidly growing town and opened a store in partnership with Charles Wilcox. They continued the business until the start of the Texas Revolution in 1835. Meanwhile, in 1831, Dr. Labadie married Mary Norment, daughter of a local family, and acquired a plantation on Lake Charlotte, which is the property under discussion.

In 1832 Dr. Labadie was appointed, along with Robert N. Williamson ("ThreeLegged Willie"), to intervene with Col. Bradburn for the release of the imprisoned colonists, and he later took part in the Anahuac disturbances. He was present at the signing of the Turtle Bayou Resolution in support of the Mexican Constitution of 1824, and volunteered to join the Army of Texan Revolution in 1836. Dr. Labadie was appointed Surgeon, First Regiment of Texas Regulars, accompanying Gen. Sam Houston in the retreat to San Jacinto. During the battle he fought under Gen. Sidney Sherman, at the same time carrying out his duties as Surgeon. After the battle, he also served for a short time as interpreter for Santa Ana.

Returning to Anahuac after the battle of San Jacinto, Dr. Labadie found that his family had fled to the Sabine along with most of the other settiers and had just recently returned. They found their plantation had been pillaged for food by other fleeing citizens, and most of the cattle had been killed. The stock from his store had been supplied to the troops in order to enable them to leave the country, and he never received compensation for it.

Times were bad in Anahuac after the war, and in $1838 \mathrm{Dr}$. Labadie decided to move his wife and children to Galveston. There in 1839 the family contracted congestive fever, and his wife died, leaving him with three small daughters: Sarah, who was 5; Charlotte, 3; and Mary Cecelia, 5 months old. He took the children to stay with their great-grandmother on his plantation (Labadie 1839), an indication that some of the older members of the family must have remained behind when he and his wife moved to Galveston. (The foregoing information, with one noted exception, was derived from an anonymous, undated summary in the files of the Chambers County Historical Commission.)

The history of the Labadie survey becomes confused at this point. The land continued in Labadie's name until 1848 (LCTR). He is listed as a non-resident 
from 1838 to 1847, then in 1848 he was apparently in residence there for a period. The tax rolls for 1849 are not available, and by 1850 Labadie is no longer listed as a landowner on Lake Charlotte. How and when the title reverted to the state is unknown, but the property was acquired in 1869 by J. Coleman Jones through a Letter Patent (CCDR 1903:Q54). Coleman was the son of Miller Jones and the nephew of J. J. Jones, property owners to the north on the McFaddin survey (see above).

Coleman Jones sold the property, including "premises and improvements," to Edward Sherman in 1903 (ibid.:052-56). According to family tradition (George Munger, personal communication), the Shermans moved into an old house already standing on the property. Soon afterward, in 1905, they built a new house a short distance down the lake shore $(41 \mathrm{CH} 234)$, and the land where the old house had stood was eventualiy put into cultivation. George Munger built a home next to the Sherman house in 1951, and in 1964 he tore down the old house. When the Corps of Engineers purchased the property, the 1951 house and other improvements were removed.

Archaeological Investigation, Labadie Site (41 CH 62) (Fig. 19)

First, a thorough survey of the area was conducted by walking parallel transects across the site east to west and collecting all artifacts on the surface. The sample thus obtained (Table 7) contained prehistoric and historic artifacts from several distinct time periods, suggesting a multicomponent site. No structural remains such as brick piers or rubble were visible. In order to delimit the site deposits, two rows of shovel tests $\mathrm{ca} .50 \mathrm{~cm}$ in diameter were dug across the terrace, extending to the clay subsoil, which averaged $30 \mathrm{~cm}$ below the surface (Fig. 19).

A $1-m^{2}$ test pit was then laid out within the area of heaviest concentration of historic and prehistoric materials. This was excavated in 10-cm levels. The second level of the excavation revealed the outlines of a pit or depression which contained charcoal as well as numerous historic artifacts, many of which appear to have been burned. Finding this deposit was particularly fortunate for obtaining a historic artifact sample from the site, since the rest of the area appears to be sterile of historic materials below the $20-\mathrm{cm}$ level. Since the area where the site is located was plowed and cultivated for many years (George Munger, personal communication), this is probably the depth of the plow zone. As excavation proceeded in Test Pit 1, a second $1-\mathrm{m}^{2}$ pit was laid out to the north, leaving a $30-\mathrm{cm}$ balk between. The trash pit appeared to extend through the balk and into the south end of Test Pit 2. Material from the trash pit was removed, screened, and bagged separately. When sterile soil was reached in both pits (see Fig. 20,b), the balk was removed. At this point it was discovered that there were two intersecting pits filled with trash. Careful excavation and separate screening of the contents established that no time difference existed in the filling of the two pits, and that they may have been animal burrows which have accidentally preserved deposits of occupational debris. Other than the noticeable concentration of artifacts in the pit, there was no difference between these materials and those found in the other areas of the first $20 \mathrm{~cm}$ of the excavation units. 


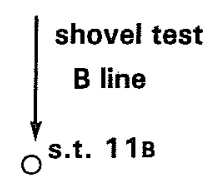

shovel test

A line
$\mathrm{O}^{\text {s.t. } 10 \mathrm{~B}}$

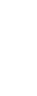

$\mathrm{O}^{\text {s.t. } 7 \mathrm{~A}}$

os.t. 9B

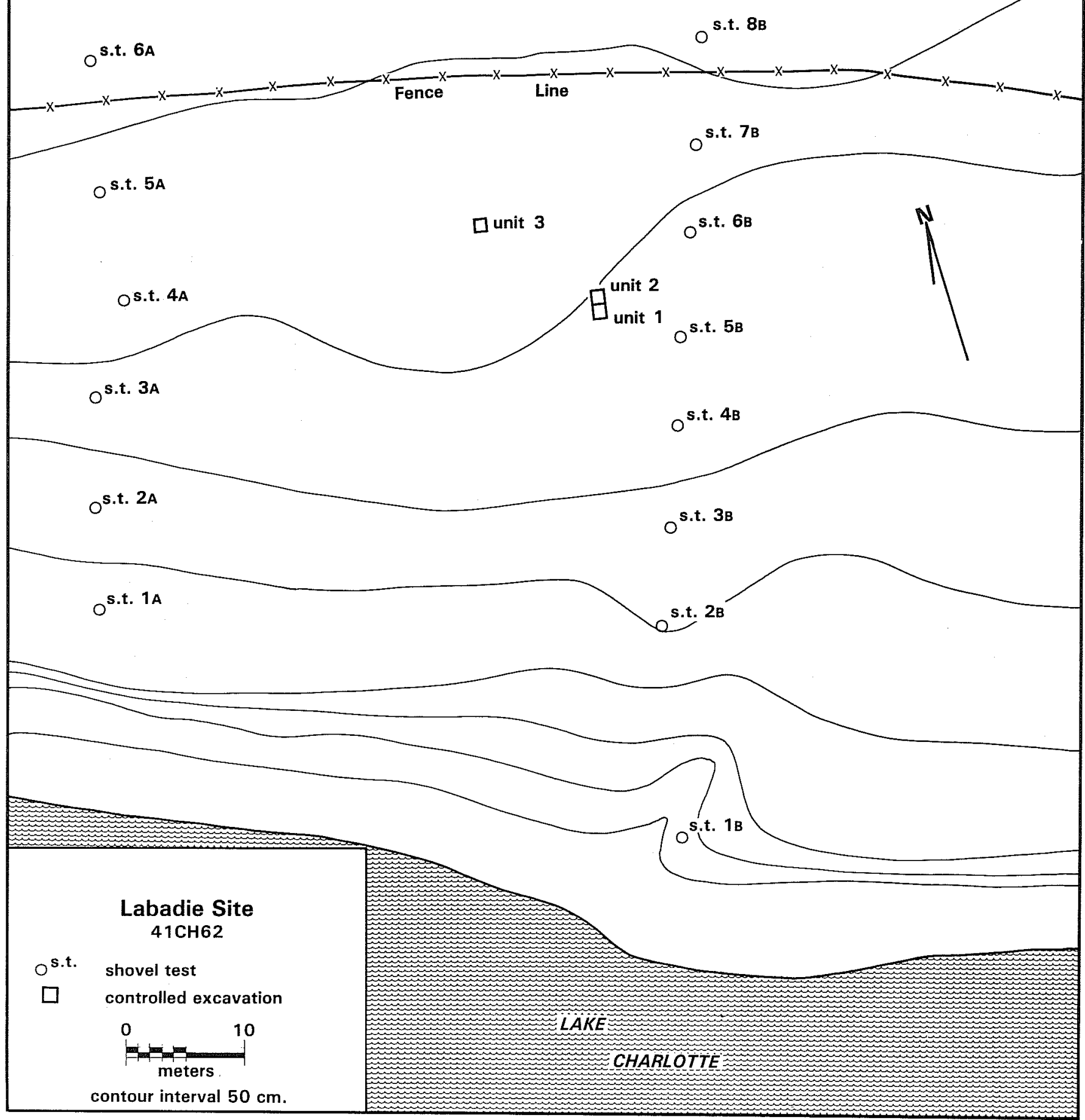




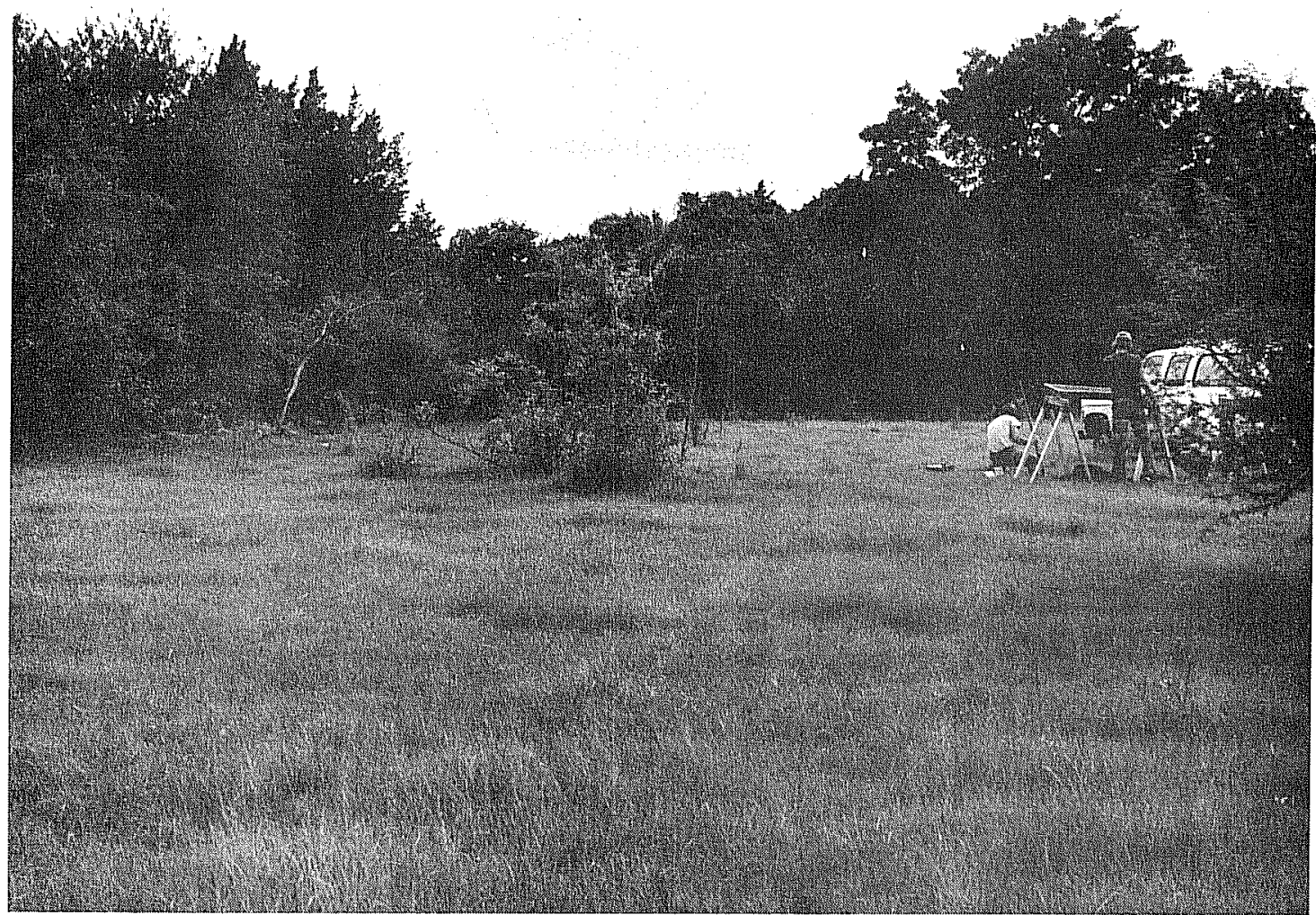

a

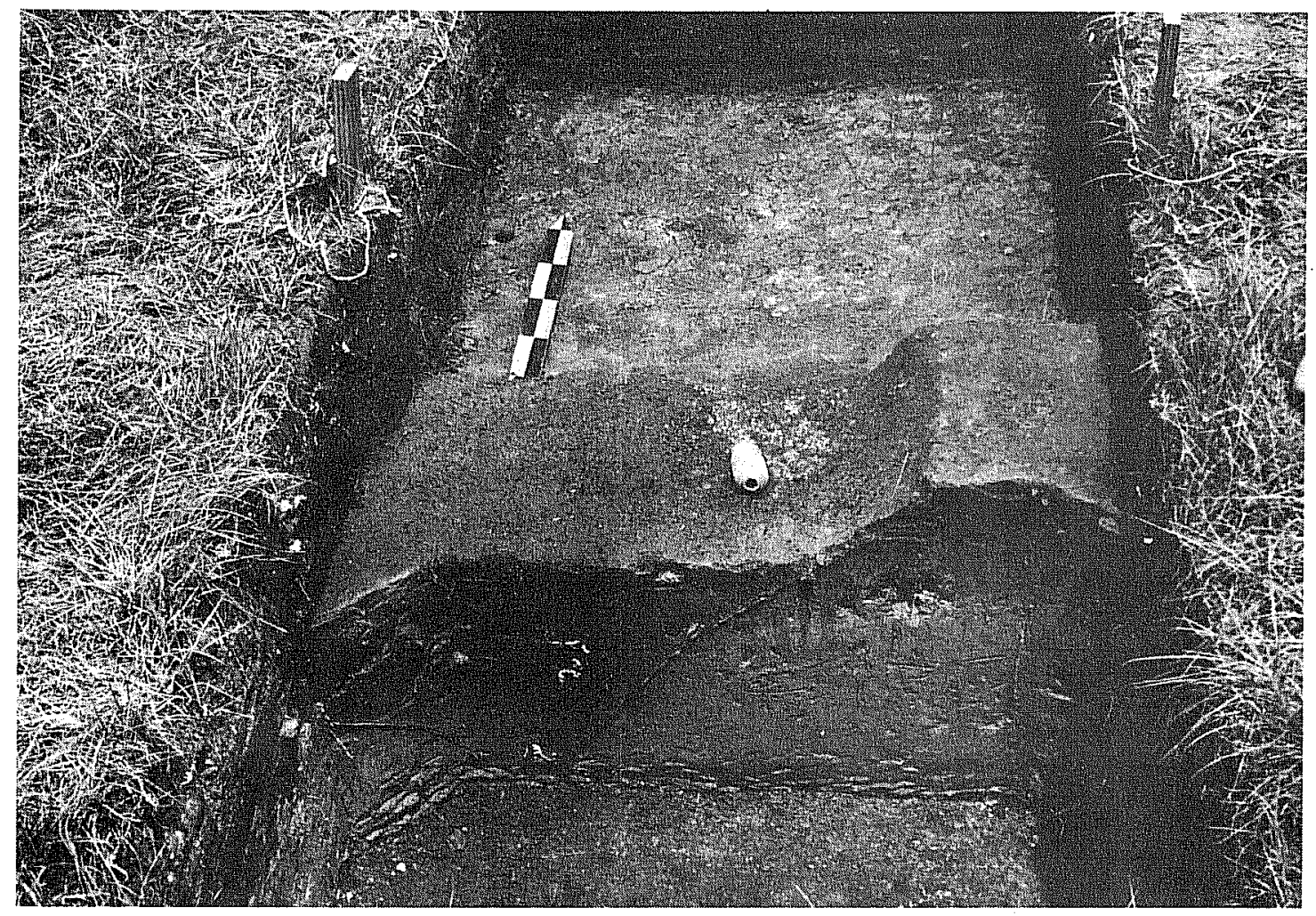

b

Figure 20. Views of $41 \mathrm{CH} 262$. a, view looking west along the top of the terrace. Excavation units 1 and 2 in right center; $b$, units 1 and 2 from the south, showing outline of trash pit in balk. 
TABLE 7. ARTIFACT PROVENIENCE, $41 \mathrm{CH} 62$

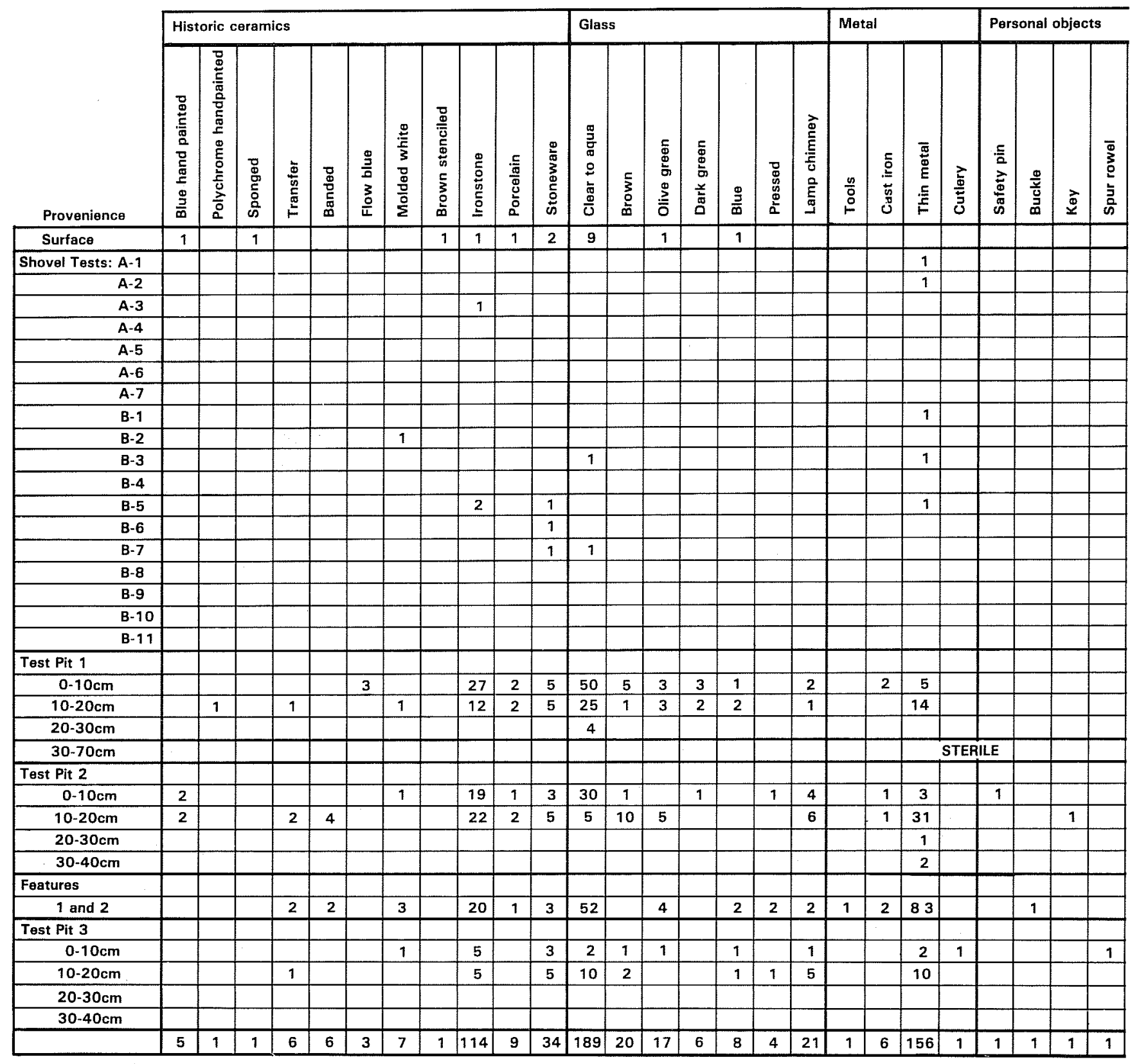


TABLE 7. (continued)

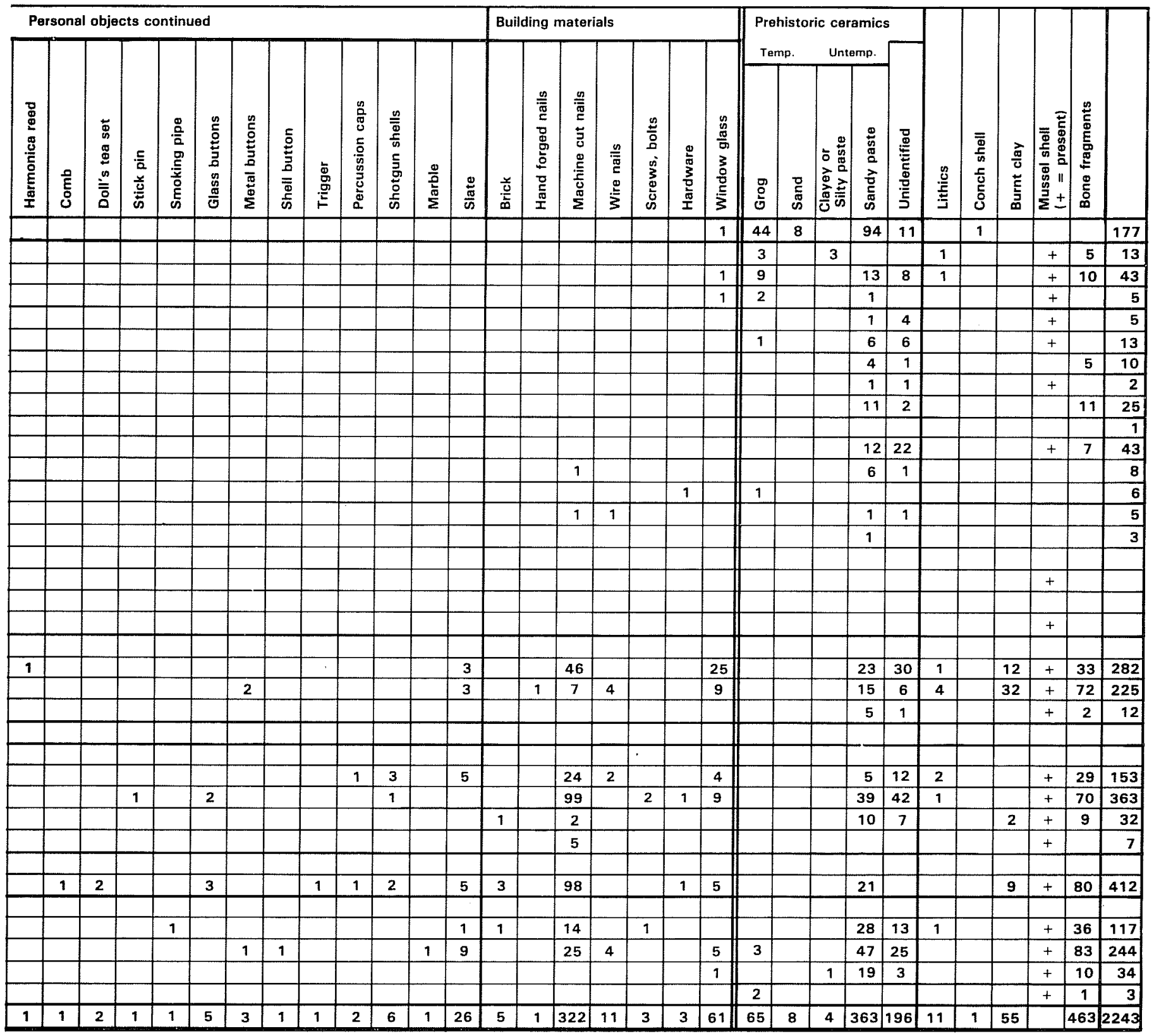


After careful observation of the terrain and the results of the shovel testing, a third $1-\mathrm{m}^{2}$ test pit was located on the top of the rise in an attempt to find traces of the house which stood on the place when Edward Sherman bought the property from Coleman Jones at the turn of the century. Although a number of interesting artifacts were found, including one sma 11 fragment of brick, no structural remains were revealed.

\section{The Historic Artifacts (Figs. 21-23)}

Since there is no stratification in the historic deposits due to frequent plowing and animal disturbance, other means must be used to determine dates of occupation. The artifactual evidence indicates two discrete time periods (and therefore possibly locations), one in the 1830s and 1840s, and one in the 1870 s to early 1900s. The earlier occupation is represented by gaily decorated earthenwares, a bottle base made by the technology of the early $1800 \mathrm{~s}$, numerous cut nails and one hand-forged one, and two types of percussion caps from weapons popular at that time but seldom seen in the area after 1870. The later period is represented by a large collection of undecorated ironstone sherds, glassware, a buckle patented in 1881, cut nails and the presence of a few wire nails, and a fragment of a type of tobacco pipe in use in the late 19th century (Table 7).

\section{Vertebrate Remains (Table 8)}

A total of 499 fragments of bone was recovered from three test pits and a series of shovel tests at $41 \mathrm{CH} 62$, a middle to late 19th-century shell midden site. Burned bone comprised 39\% of the recovered fragments (194 pieces). Forty-one pieces were recovered from Feature 1, and $11(27 \%)$ of those were burned.

of the total recovered bone from this site, 75 elements (15\%) were identifiable at least to vertebrate class. The majority of the identifiable material $(76 \%)$ were mammals, with pig being the most common mammal represented. The 26 elements of Sus scrofa yield an MNI of only one individual. None of the suid elements had been burned, and they represent the non-meaty parts of the animal, i.e., skull, backbone, and feet. The 12 elements listed as large mammal are too fragmentary to determine species reliably.

Bos taurus is the other domesticate represented in this sample. The nature of an incisor enamel fragment and the size of a tibia shaft again indicate an immature individual. The other element is a broken tooth which is too fragmentary to assess maturity.

Deer, probably white-tailed deer, is native to Chambers County and was undoubtedly an abundant game animal along tree-lined creeks in the area. Both forequarters and hindquarters are evident in the recovered material, al though there is a minimum of one individual present. Two forequarter elements (a left radius and a right humerus) were burned. Only two fragmentary deer teeth were recovered, both from Unit 3-2. At least one mature individual (e.g., fused distal radius) and one sub-adult (e.g., unfused calcaneum) are represented. 
Figure 21. Ceramics from $41 \mathrm{CH} 62$, Labadie Site.*

a. blue transfer pattern on pearlware plate, before Civil War in Texas

b. black transfer pattern on pearlware plate, before Civil War

c. red transfer pattern on pearlware plate, before Civil War

d. red sponged design on pearlware plate, before Civil War

e. blue hand-painted design on pearlware bowl, early 19th century

f. brown bands on pearlware mug, early 19th century

g. ironstone plate, probably post Civil War

h. gold-banded porcelain cup, late 19th century

i. flown blue design on peartware plate, 1825-1860 (Ray 1974:69)

j. brown stenciled design on earthenware plate

k. stoneware with green hand-painted design

1. porcelain fragment of doll's tea pot

* Al1 specimens shown actual size 


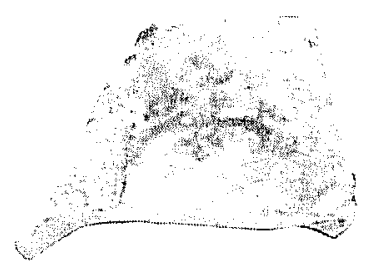

a
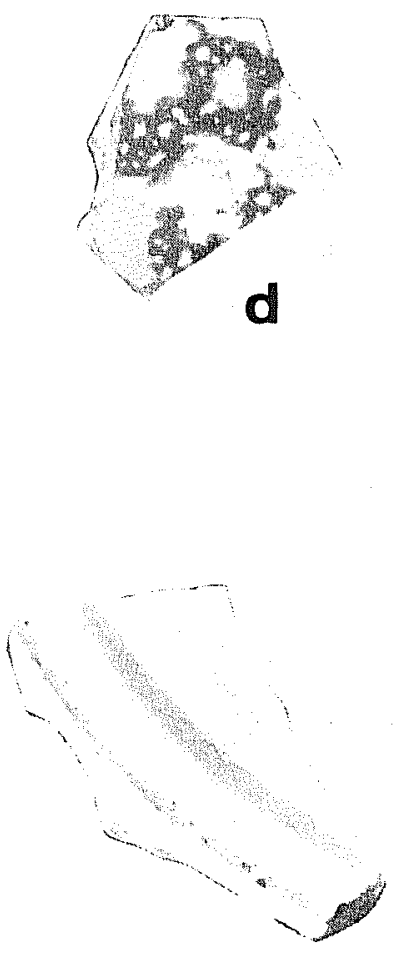

g

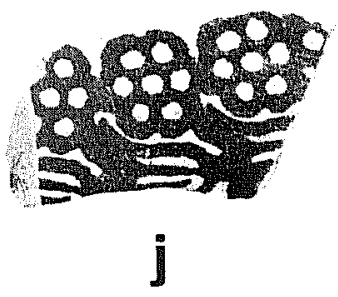

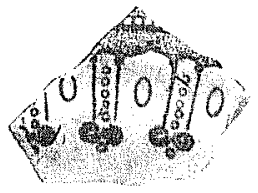

b

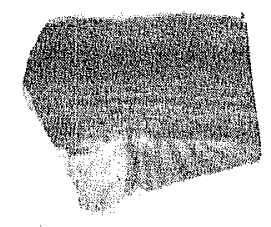

e
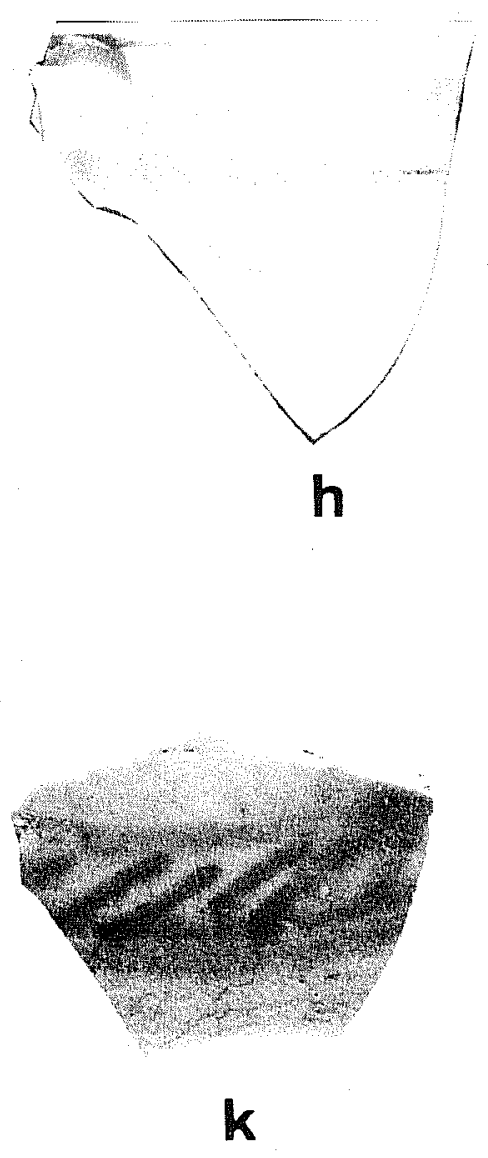
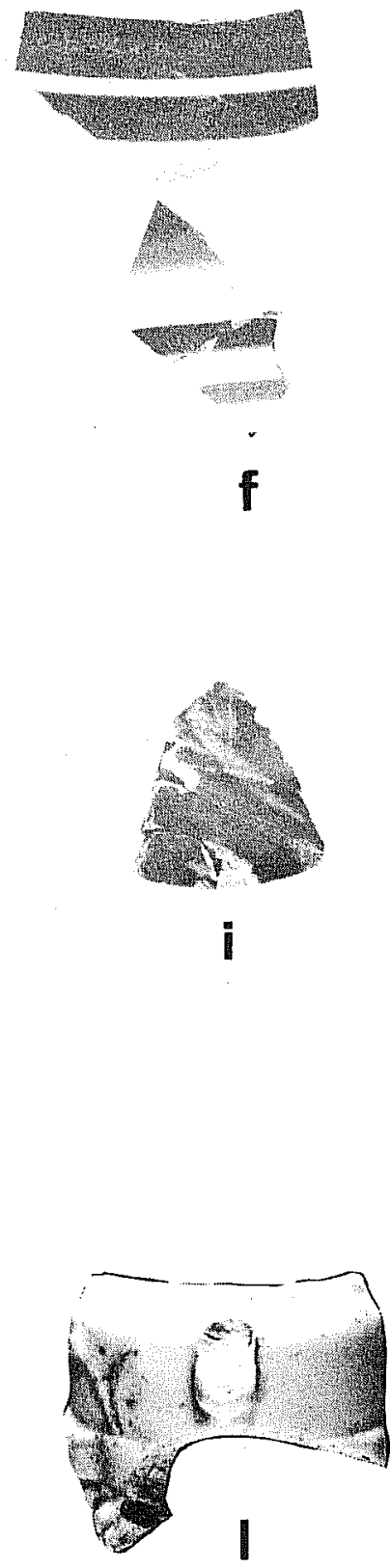
Figure 22. Artifacts from $41 \mathrm{CH} \mathrm{62,} \mathrm{Labadie} \mathrm{Site.}$

a. piecrust button, 1840-1880 (Schuetz 1969:40)

b. plain white porcelain button, post-1840 (ibid.)

c. percussion cap for pistol in use ca. 1840-1860 (Sam Nesmith, personal communication)

d. percussion cap for musket in use ca. 1840-1860 (ibid.)

e. copper-headed tack with iron shaft

f. gold-washed stick pin or scarf pin, popular ca. 1890-1910

g. ceramic marble, 1884-ca. 1918 (Randa 11 1971: 103)

h. ceramic pipe fragment, salt glaze, post-Civil War (Wilson 1966:Figure 5H)

i. metal button

j. patented buckle, dated 1881

k. composition comb fragment

1. key fragment

m. spur rowe1

n. trigger 

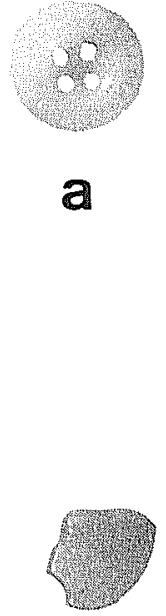

e
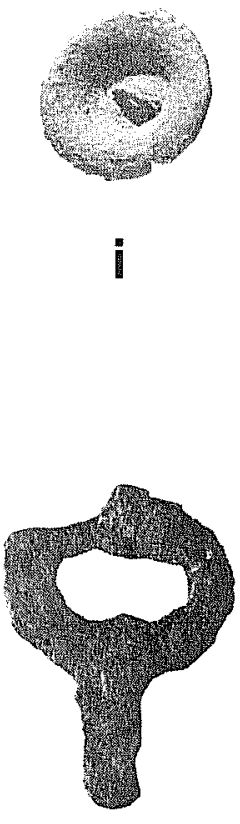

I

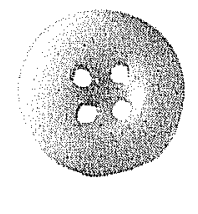

b
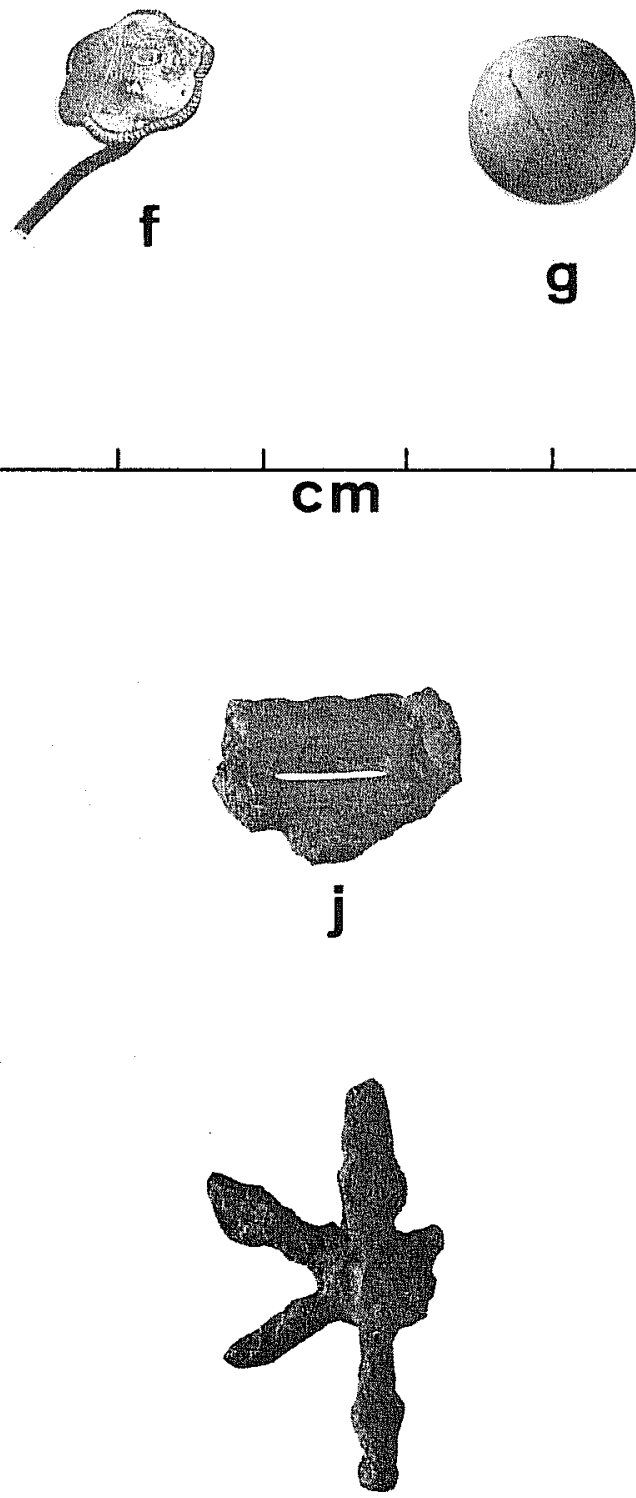

g

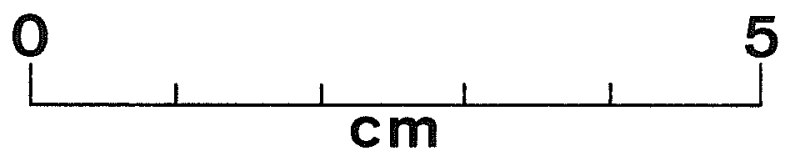

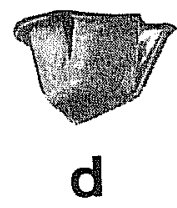

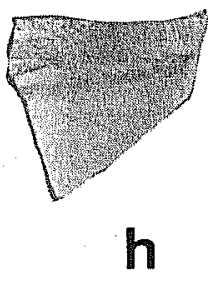

5
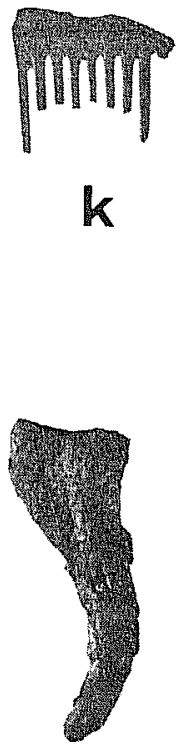

n

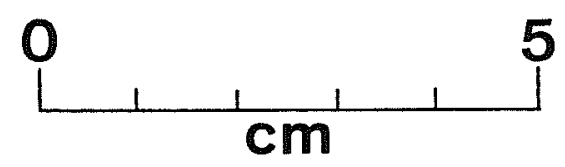


Figure 23. Glass and Metal Artifacts from $41 \mathrm{CH} 62$, Labadie Site.*

a. pale blue molded glass vessel

b. pale aqua bottle base, free blown, early 19th century (Lorrain 1968:36)

c. clear glass bottle neck, hand tooled, ca. 1850-1880 (libid.:40)

d. aqua condiment bottle, mold made, ca. 1880-1900

e. metal fork

f. hand-wrought iron hinge

* Al1 specimens shown actual size 


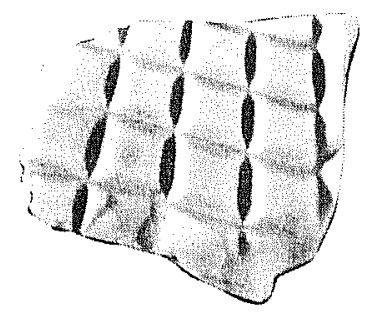

a

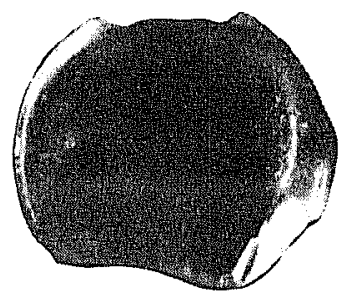

b

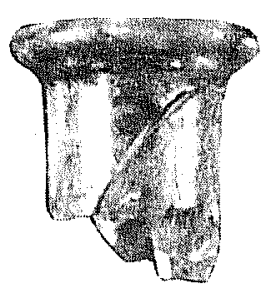

c
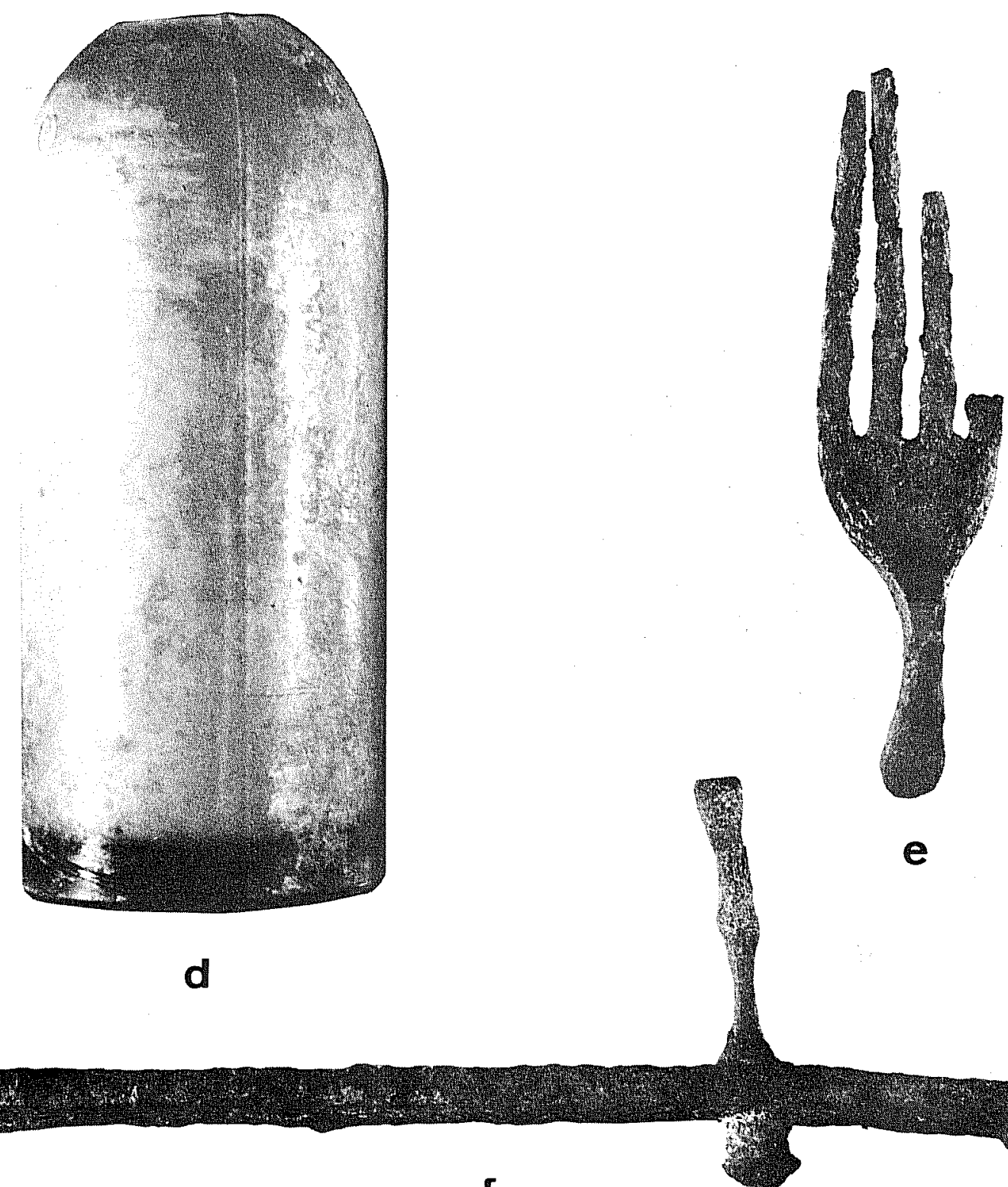


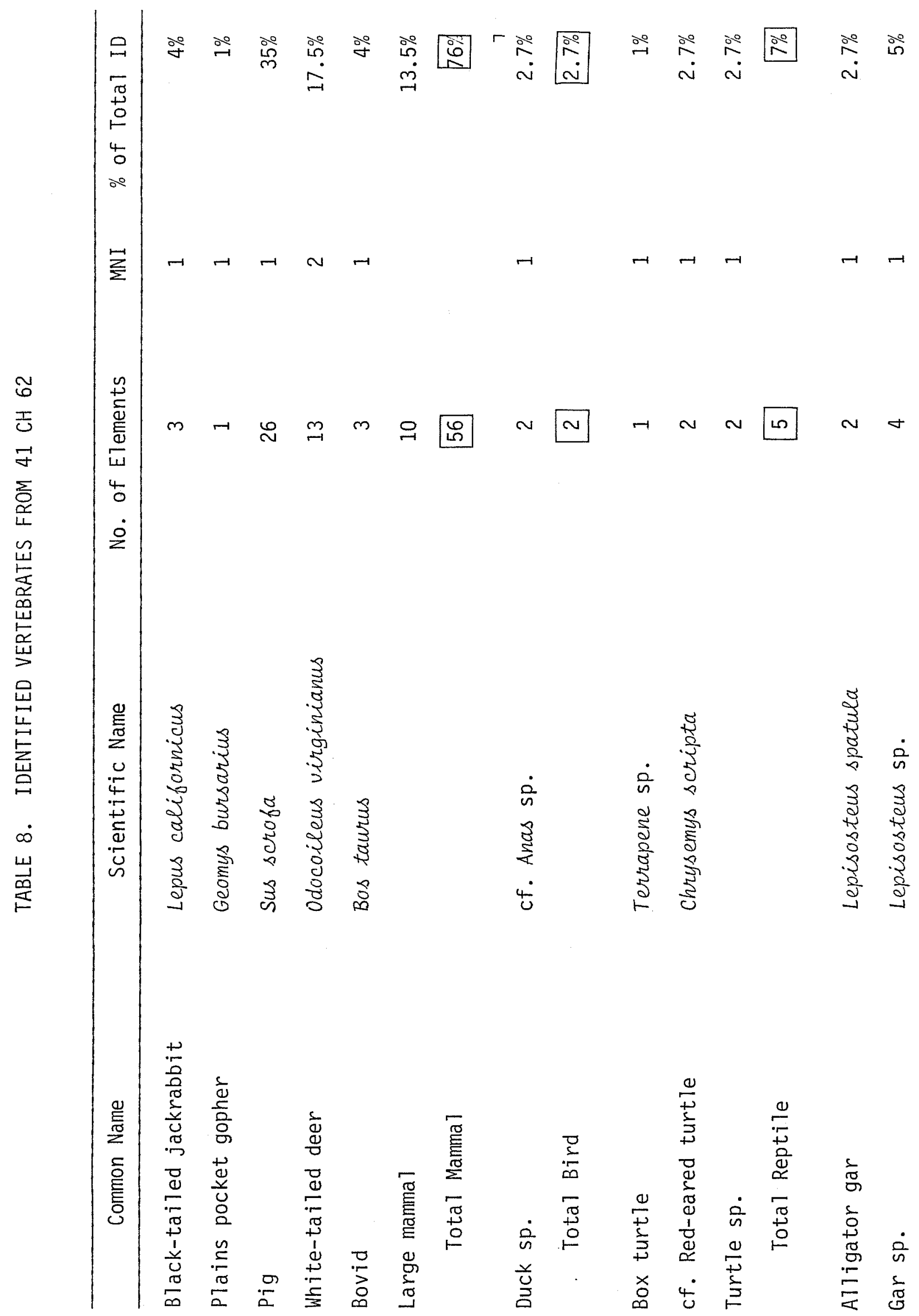




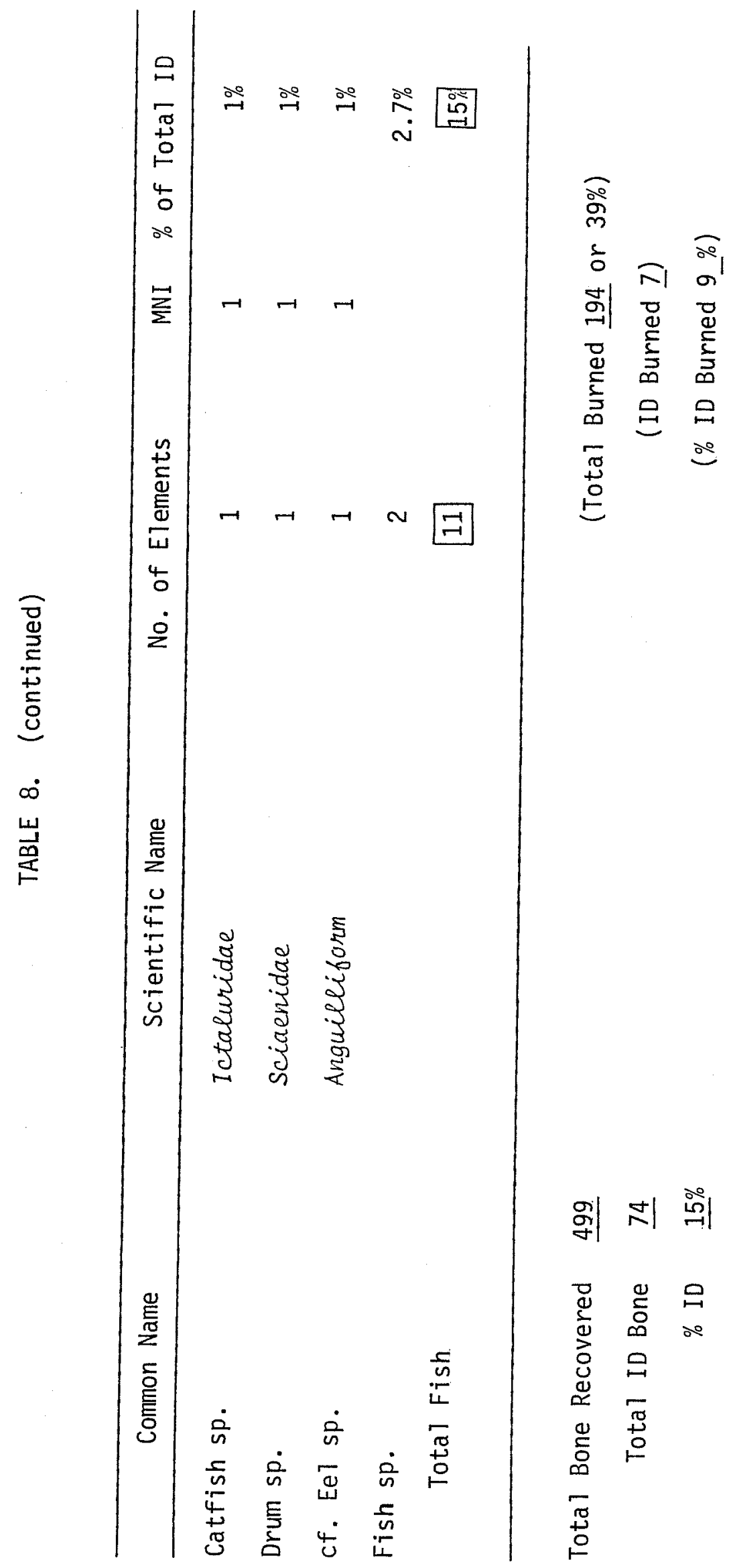


Feature 1 contained only two identifiable elements: a metapodial condyle from a deer and a third phalanx of a pig.

Chambers County is beyond the current distribution boundary for black-tailed jackrabbit according to Davis (1974), although Burt (1952) and 01sen (1964) include Chambers County within range in their publications. These elements (a broken scapula, a molar, and a burned calcaneum) are too big to be swamp rabbit.

Pocket gopher is also indigenous to this area and should probably be considered intrusive in this case.

Birds are represented by two elements best identified as belonging to the surface-feeding ducks, Anatinae, which prefer shallow waters such as marshes and ponds (Peterson 1960). Most of these ducks frequent Texas in the winter as migrants except for the mottled duck (Anas fulvigula), which is a year round resident along the coast (ibid.).

Turtles are the only reptiles from this sample and consist of one carapace fragment from a box turtle (either Terrapene ornata or $T$. carolina) and a long bone and marginal bone from a large turtle of the chrysemys family, probably the common red-eared turtle. Both species are prevalent in Chambers County.

The identified species of fish are freshwater types that can tolerate brackish waters. At least two species of gar are identified as alligator gar and probably a large longnose gar. A drum otolith from Unit 3-1 could be from either the black drum, a marine species, or the common freshwater drum; however, the relatively small size of the otolith would favor the smaller freshwater species. A large vertebra centrum most closely resembles the flathead catfish, but large blue catfish are also native to this area (Hubbs 1976).

A fin spine from a large carp (identified by Dr. Paul Parmalee) was recovered from the surface. This species was introduced from Asia via Europe to North America in the 1870s or $80 \mathrm{~s}$ (Zim and Shoemaker 1956) and quickly spread throughout U.S. waterways.

Of the identified mammals, only one element of deer (a left humerus) and the tibia shaft of the immature bovine showed butchering marks. The deer humerus had four light cuts (V-shaped in cross-section) and two deeper notches cut towards the distal end at an angle. These two groups of cuts were made just above the elbow joint, possibly in order to cut the strong tendons at that junction. These cuts resemble those found on deer bone from prehistoric sites, but the instrument used to make the cuts is indeterminable. By contrast the tibia shaft was cut by a saw which smoothly removed both articular ends.

Unit 3-2 yielded four large mammal fragments bearing alteration marks. One triangular fragment has a notch resulting from three to four $V$-shaped cuts made obliquely into the bone. Two fragments have worn spiral fractures with light cuts near the tip of one and deeper cuts on the tip of the other. One other fragment shows much gnawing and/or notching at one end and a smooth, shiny flattened point at the other end. This piece is oblong in cross-section, 
and part of the tip is missing due to an old break. The opposite end is more round in cross-section and has an overall smaller circumference than the point. It is difficult to determine whether the gnaw/notch marks at this end were made by animals after the bone was used as a tool or whether the notches were made for hafting the point.

\section{Observations and Conclusions}

The overwhelming predominance of sandy paste untempered ceramics and a few examples of clayey or silty untempered sherds in the site suggests that there may have been periodic occupations over quite a period of time before the Spanish arrived. The red-filmed variety has been dated by Gilmore (1974:5) and Aten (1979) at A.D. 600 to 1400, and the grog-tempered ware was in use from about A.D. 1000 to European contact (ibid.). The only diagnostic lithic artifact present was a Perdiz arrow point (Fig. 3), which is consistent with the ceramic dates at ca. A.D. 1000 to 1500 (Suhm, Krieger, and Jelks 1954:504).

There are several possible explanations for the lumps of burned clay which were found. The fragments range from $50 \mathrm{~cm}$ to $1 \mathrm{~cm}$ in diameter, and no clear impressions of sticks or grass could be detected which would suggest jacaltype structures of sticks and mud. They could be merely remnants of burned hearth areas where fires were built on the natural sandy-clay surface. Two small stone fragments, one of quartzite 5 to $6 \mathrm{~cm}$ in diameter, and one of sandstone $1.5 \times 2.5 \mathrm{~cm}$, have smoothed faces suggesting that they may have been parts of grinding stones, but the pieces are too small to make a positive identification.

Although no artifacts such as glass trade beads or gun parts were found on the site, it is possible that this was one of the camp sites of the Orcoquisac in the 17th and 18th centuries. More intensive excavations over a larger area would help to confirm or reject this supposition.

The analysis of the historic artifacts indicates the brief occupation of the site in the 1830s and 1840s, probably by the Labadie family. This was followed by a period of abandonment, a longer occupation in the late 19th century by the Coleman Jones family, and the brief Sherman occupation while they were building a new home nearby.

\section{Recommendations}

This site, along with $41 \mathrm{CH} 63$, which appears to be actually a continuation of the site to the north along the lake shore, is one of the largest and most promising sites within the reservoir for yielding information on the aboriginal inhabitants of the area.

The historical importance of the site lies not so much in remaining structures, for there may well be none left, but in its connection with a man of historical importance and its early date. We recommend, therefore, that $41 \mathrm{CH} 62$ and $41 \mathrm{CH} 63$ be nominated to the National Register of Historic Places. When plans are drawn to make the area into a public park, care should be taken to leave 
the sites as undisturbed as possible, and where disturbances are necessary, mitigation should be done to recover both prehistoric and historic information.

The rise in the water level due to the proposed reservoir will undoubtedly increase erosion in this area, as natural wave action is intense on this shore of the lake. The water will extend to the base of the bank, causing undercutting and collapse. The results of occasional flooding from storms are evident in collapsing areas of bank and shells strewn along the beach above the present water level. It is essential that action be taken to protect the bank from this erosion or the site will be badly damaged.

Archaeological Investigation, Munger Site (41 CH 234)

Survey was limited to surface examination of the area, noting the concrete block piers which had held the George Munger house, a cattle guard, concrete slabs, and other 20th-century improvements. Also present are numerous other trees and shrubs in the vicinity of the Sherman house built in 1905, although there are no structural remains of the house visible today.

\section{Recommendations}

Since this site contains no structures of particular historical or architectural significance, no further investigations are recommended. If the area is to be developed into a public park, we suggest marking the site with an appropriate sign indicating the Sherman and Munger family ownership.

\section{ORCOQUISAC HISTORIC DISTRICT}

In July 1971 a Historic District was officially designated by the National Register of Historic Places. This District includes the site of Blancpain's trading post and the first presidio-mission complex, the second site of the mission, and the second site of the presidio, along with a number of historic and prehistoric Indian campsites located in the same area (National Register 1971). The prehistoric sites which are not directly related to the historic Spanish sites are reported by Day in Section II.

The area is densely overgrown except where cattle keep the growth grazed down. The land is fairly low and level for a considerable distance at the western end of the south shore of the lake, then slopes upward about 10 feet to a low hill upon which the second site of the mission was built. The land continues at this elevation around the balance of the south and southeast shores of the lake to where the second site of the presidio was located. The area is crossed east-west by a number of pipeline easements, one of which crosses $41 \mathrm{CH} 57$ and runs between $41 \mathrm{CH} 54$ and the lake.

The intent of the investigations has been to establish as accurately as possible the northern boundary of each of the sites in the District, and to determine what possible effects the proposed reservoir would have on each. In order to do this, intensive research in primary archival sources and other materials has 
been imperative. In addition to archival materials made available to us by John Clay, copies of recently discovered Spanish documents in the San José Mission Research Library have been obtained and utilized. These include a series of letters and reports concerning the maintenance of the presidio and its personne1 from 1760 to 1763, part of which is an interesting inventory of goods being delivered to the presidio. Also included is a detailed inventory of the remaining goods belonging to the mission eight days after it had been badly damaged by a hurricane on September 4, 1766. Not only have these new documents helped in recreating the history of the Spanish complex; they also provide important information on the material culture of the times and aid in interpretation of evidence found in the archaeological investigations.

Later archival documents and reputable secondary sources have helped to trace the 19th-century history of the District and to explain some of the evidences of later occupation which are present. However, a great deal more can be done along these lines by future researchers. For instance, a large part of the Historic District lies within the Thomas Rankin survey. An early map (Thompson 1828 ) and the Atascosito Census of 1826 (Osburn 1963:314) locate James Mi1ler and his family (for whom the lake was first named Miller's Lake) on the south shore of Lake Milier in the early 19th century. This is confirmed by early land records (General Land Office 1964:86), which further locate Miller in what would become the Rankin survey by 1844. So far, the site of the Miller homestead has not been identified. For the purposes of delimiting the areas of occupation and assessing the need for protection for the sites, primary emphasis was placed on the portions of the sites which are closest to the reservoir.

\section{Presidio San Agustín de Ahumada, $41 \mathrm{CH} 57$}

\section{History}

The early history of this site is covered in detail in Section III. Although the site is generally referred to by the name of the presidio, it is actually composed of a number of sites in one location. When Joseph Blancpain built his trading post there, he probably chose the she11 mound because it would afford good drainage in wet weather, not realizing that it had been a prehistoric camp site. Lt. Marcos Ruiz dutifully established the presidio "on the site of "the trading post, in the same manner as Presidio Nuestra Señora de Loreto had been built on the site of La Salle's Fort St. Louis in 1722 (Peña 1935:64-65). The missionaries' house and church were apparently located nearby, perhaps on the slightly elevated area $30 \mathrm{~m}$ to the east of the presidio (Fig. 24). Judging from artifacts recovered during testing of the site in 1970 (author's personal observation), an early Anglo-American settler also found the spot a likely place to live. Ceramics similar to those found on the Labadie site point to an early 19th-century occupation. There are also late 19th-century artifacts on the surface, probably left by the William Cooper family who lived in the area at the turn of the century (Octavia La Four, personal communication). 
This page has been

redacted because it

contains restricted

information. 


\section{Archaeological Investigations}

The site is located on a low mound on what was once the southwest shore of Lake Miller. The mound contains a prehistoric she11 midden. The lake has silted-in rapidly in recent years; according to local informants it once had a clean, sandy bottom in this area. In the 18th century the site was actually on the lake shore. The area is overgrown with a tangle of weeds, trees, vines, and undergrowth which is relieved only where several pipeline easements are cleared and mowed regularly.

In order to establish the northern 1 imits of the site, documentary evidence was examined for information as to the general size and plan of the Spanish presidio and mission as they were first bui7t. No drawings of the layout of this site have so far been located, nor do any complete descriptions or inventories exist. Certain clues can be found, however, in the reports and correspondence of the period, which help toward a theoretical reconstruction.

The accounts of the confrontation between Pacheco and Ruiz in 1764 mention the plaza, the captain's quarters, the presidial church (possibly the first mission church), the store, and the barracks adjoining the captain's quarters (Bolton $1970: 370-371)$. This sounds very similar to the plan of the second presidio as seen on the Urrutia map (Fig. 25). Therefore, it seems reasonable to presume that the first presidio may have occupied a site of the same general size as the second, which was approximate1y 8,000 square meters (Tunne11 and Ambler 1967:Fig. 2).

During the winter of 1969-70, members of the Houston Archeological Society, under the direction of W. L. Fullen, conducted extensive surface collecting and limited subsurface testing on $41 \mathrm{CH} 57$. The area was mapped and a grid laid out so that the entire site lies in the southeast quadrant (that is, each point within the site bears a south and an east designation), with the zero point some $30 \mathrm{~m}$ to the northwest of the edge of the bank (Fig. 24).

The testing in 1970 located what appears to be a prepared she11 layer into which postholes had been dug about $55 \mathrm{~m}$ south of the lake shore. Surface collections carried out in 1967 and 1970 revealed Spanish and French ceramics concentrated primarily in an area 10 to $60 \mathrm{~m}$ south of the shore line (W. L. Fullen, personal communication). Since this area contains some noticeable elevations on the topographic map, it seems likely that the Spanish presidio/ mission and, therefore, the French trading post were located there.

With the above information in mind, it became apparent that the embankment at the edge of the old lake and the swampy area to the north might yield information useful in determining the location of the wharf and the French ship which were located somewhere adjacent to the presidio, as related in Section III of this report. The following concerted program of testing was then carried out, with the help of a number of members of the Houston Archeological Society and interested local volunteers.

A series of six $30-\mathrm{cm}$ diameter shovel tests were dug along the top of the bank. Each test was excavated through or deeply into the shell midden deposit which covers this part of the site. Al1 soil removed was screened through $1 / 4-$ inch 
This page has been

redacted because it

contains restricted

information. 
mesh; observations were recorded on soil color, texture, and content, and artifacts were bagged for analysis.

A total of 37 unidentifiable prehistoric sherds, 4 grog-tempered sherds, and 37 sandy paste sherds was recovered from the shove1 tests. One flake fragment and one primary flake were the only lithics found. One small lump of burned clay was also recovered. Faunal remains recovered are described below.

The only Spanish artifacts found were two sherds of blue-on-white majolica, four fragments of a heavily patinated green bottle, and part of a metal buckle (Fig. 26). The sherds were collected from the surface in the general area of the core testing; the bottle came from Shovel Test 3 and an animal burrow nearby, and the buckle was $10 \mathrm{~cm}$ below the surface of the swamp between and to the north of Shovel Tests 3 and 4.

Systematic corings ca. 4 inches in diameter were taken on north-south grid lines $10 \mathrm{~m}$ apart through the swamp just north of the bank, in order to determine the make-up of the deposits located there and the depth of the original sandy lake bottom (see Fig. 24). A search was also conducted for remains of the Blancpain sloop and the presidio wharf mentioned in the Spanish documents. The depth of corings varied, averaging $60 \mathrm{~cm}$. Sand was found beneath dark-gray-to-brown silty clay deposits at approximately 60 to $100 \mathrm{~cm}$ below the ground level at the top of the bank. No evidence was found of sloop and/or wharf in these corings.

A test survey was conducted with a magnetometer in the low-lying area at the north side of site $41 \mathrm{CH} 57$ where it is thought that some remains of Joseph Blancpain's boat may exist. The purpose of the test survey was to assess the feasibility of conducting a ful1-scale magnetometer survey of the area.

The instrument used was a cesium alkali vapor magnetometer with an accuracy of \pm 0.1 gamma, or, in other words, with the capability of measuring the earth's magnetic field with an error of only two parts in a million. This is about 10 times more accurate than the commonly used proton precession magnetometer.

Using the grid described above, eight lines with marks every meter were positioned at $10-\mathrm{m}$ intervals. The lines, normally $10-\mathrm{m}$ long, extended from the old river bank north into the low-lying area. At each grid mark a "low" (20 cm above surface) and a "high" (160 cm above surface) magnetometer reading were taken. "Low" readings provide better resolution of buried ferromagnetic objects, but they are more sensitive to surface trash.

Specific questions addressed in the test survey were:

1. Is the resolution of the magnetometer sufficient?

2. Is magnetic interference a problem?

3. What field procedures would be appropriate for a full-scale survey?

Answers to these three questions, in light of the test survey results, are given below. 
Figure 26. Spanish and Indian Artifacts.*

a. bead, blue, Harris No. 13 (Harris and Harris 1967:140) from $41 \mathrm{CH} 103$

b. bead, blue, Harris No. 11 (ibid.) from $41 \mathrm{CH} 22$ area

c. blue-on-white majolica from $41 \mathrm{CH} 57$

d. blue-on-white majolica from $41 \mathrm{CH} 57$

e. green glass bottle with heavy gold patina from $41 \mathrm{CH} 57$

f. green glass bottle with heavy gold patina from $41 \mathrm{CH} 57$

g. molded brass buckle from $41 \mathrm{CH} 57$

h. modified conch she11 tool from $41 \mathrm{CH} 62$

* A11 specimens shown actuár size 

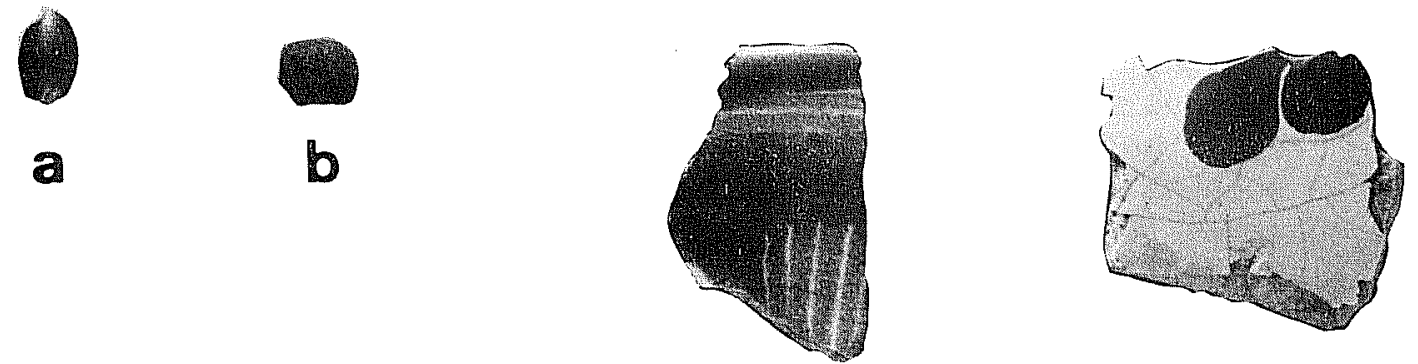

C

d

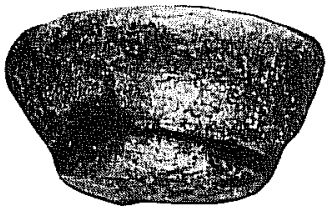

e
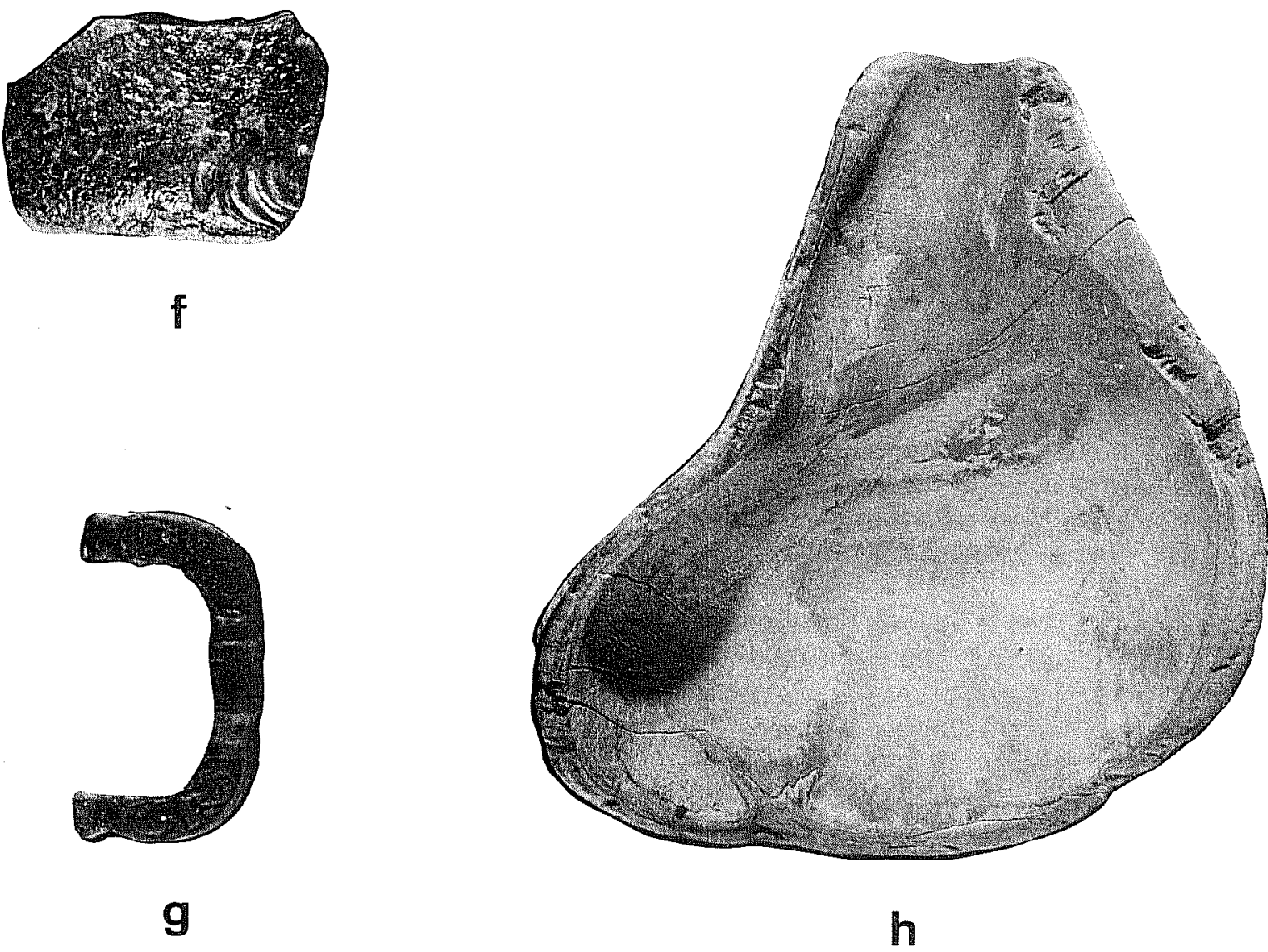
Resolution. Whether an object can be detected depends upon its depth of burial, size, and ferromagnetic content. In this case, it is difficult to draw any substantive conclusions as to detectability because the level of the water bottom during the French/Spanish period has not been ascertained. Large and/or massive iron objects such as a cannon or cannon bal1 would certainly be detectable at the expected level (a depth of $1 \mathrm{~m}$ or so). Also, a concentration of small items, such as nails, might be detectable. The detectability of small individual items is questionable.

The following gives an example of the capability of the magnetometer used. An iron stake, several centimeters in diameter and standing approximately vertical (the most difficult position for detection), was discovered at grid position S4.7/E50.5 (see Fig. 24). The top of the stake was $35 \mathrm{~cm}$ below the surface, and metal locators produced no indication of it at all. The magnetometer, however, measured an anomaly which in size was more than a meter in diameter at the surface and whose peak value of almost 500 gamma is about 5000 times the resolution of the instrument.

Interference. There was considerable interference caused by modern junk scattered on the surface in the western third of the area surveyed. Few meaningful results were obtained for that area. There also may be some buried modern objects such as the stake mentioned above.

Another problem is the nearby pipelines, which distort the magnetic field over the entire area surveyed. In particular, the magnetic contours are aligned eastwest, parallel to the pipelines. However, this distortion is fairly predictable, varies smoothly and is not extremely large except in the immediate vicinity of the pipelines. If properly taken into account, it should not be a hindrance.

No interference was noticed from power lines, antennas, or magnetic soil components.

Recommendations for field procedures. The modern junk must be removed from the surface prior to survey; a metal detector can aid in this task. Magnetometer readings should be taken on a grid of no larger than $1 \mathrm{~m}^{2}$, with anomalies, when discovered, being located precisely. The grid should be laid out ahead of time to make maximum use of the magnetometer. Readings should be taken at a fixed "low" distance above the surface; the "high" readings, as taken in the test survey, are not needed if all the surface trash is removed.

In summary, the test survey has indicated that a full-scale magnetometer survey is feasible. Most of the interference problems encountered in the test survey can be minimized or neutralized by proper preparation of the survey area and proper processing of the readings. A relatively fine grid spacing is recommended for the measurements in order to obtain desired details; this can, with adequate planning, be accomplished quite efficiently.

Using the grid laid out for the other testing, a metal locator survey was conducted over the area. The locators used were a Heath Kit Metal Locator and a Coinmaster 5000/D GEB Metal Detector. Readings were plotted on charts, using a graduated scale of dots which corresponded to intensity. Metal artifacts thus located were recovered for analysis. These were, with one exception, nails, tin cans, and barbed wire recently deposited by local fishermen. One 
Spanish artifact, a buckle fragment (Fig. 26,g), was recovered by this method near the location of a previous test trench and probably from the backdirt of this effort. The range of the detectors probably did not extend deeply enough to respond to articles on the 18th-century lake bottom.

Vertebrate Remains (Table 9)

A total of 371 bone fragments was recovered from shovel tests and core samples made at $41 \mathrm{CH} 57$, a Spanish presidio on a she11 midden. Forty-eight percent (179 elements) were identified at least to vertebrate class. A small percentage $(6 \%)$ of the recovered bone was burned; only 8 fragments from the identified materials were burned. Of these identified burned bone, a11 but one fragment were fish.

Fish remains constitute $89 \%$ of the total identifiable sample. This high frequency is due to the presence of 110 alligator gar scales. Evidence of alligator gar was recovered from every testing unit except E89/S20 and E99/S20. Four of these large scales had been burned, and one sculptured cranial element was charred. Other gar scales were too fragmentary to be identified as L. spatula; however, several scales from E40/S13 were decidedly too small for alligator gar and probably represent at least one individual of a smaller gar species, i.e., longnose gar or spotted gar, which are native to Gulf drainage areas (Eddy 1957).

Other identified fish included a cranial element (quadrate) resembling the type found in the sheepshead, a marine relative of the drum known to be "a common inshore sports fish" (Hoese and Moore 1977:200). The other quadrate is much larger and probably belongs to one of the large Sciaenids, i.e., black drum, spotted weakfish, or "channel base." Each of these large fish ( 3 to 5 feet) often enter shallow bays of the Gulf (Hoese and Moore 1977).

One turtle shell fragment out of seven had been burned. It is a thick fragment from an unidentified species. At least two individual turtles are represented by two neural bones of different thicknesses.

Onty 13 mammal bones were identified, comprising $7 \%$ of the total identified sample. Eight elements from at least one deer accounted for most of the mammalian remains, and these elements are from non-meaty portions, i.e., feet, sku11, and spine. Only one deer tooth fragment was recovered, and the amount of wear on this fragment suggests a deer approximately 1.5 years old at death. One of two fragments from a deer axis (second cervical vertebra) had two cuts in roughiy an X-shape.

A mandibular premolar fragment from E99/S20 is from a cow, and two teeth fragments from E59/S20 are very fragmentary; however, the thickness of the enamel and size of the root suggest Bos taurus as weil. Two vertebrae fragments are smaller than deer or cow, but species is indeterminable.

\section{observations and Conclusions}

Despite the disturbance of the pipelines, it appears that a large percentage of the site may still be relatively intact. The 1979 testing established that the 


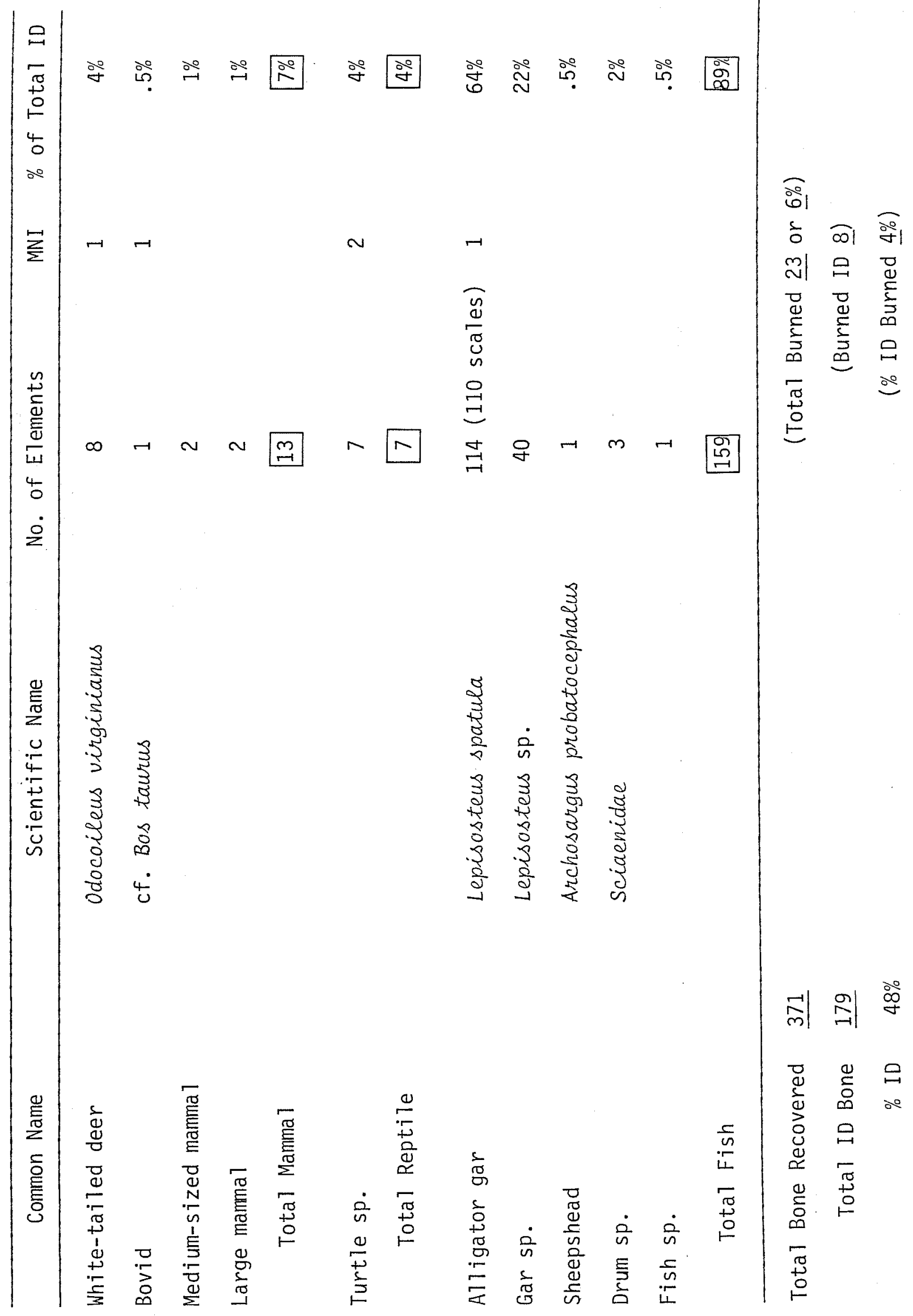


prehistoric shel1 midden extends to the edge of the bank, but the historic site probably sits back somewhat from the edge, perhaps as much as $10 \mathrm{~m}$ at its closest point (Fig. 24). No trace of Blancpain's dock or boat was found along the shore line, but it seems likely that both are present somewhere in the area. It may be that testing farther to the east would be more productive. The main concentration of the prehistoric sites appears to be near the water, perhaps at the high knoll on the northwest end of the site. The artifact sample obtained was too small to date the occupation with any certainty.

\section{Recommendations}

The importance of this site has already been confirmed by its admission to the National Register. The effect of a 4-foot water level on this area will be to bring the water up to the bank and cause both undercutting through wave action and more frequent flooding of the entire site. The higher water level will cut off the site from easy access and will therefore serve to protect it somewhat from trespassers, but it will add to the problems of future archaeological work in the area. A method should be designed to stabilize or in some other way protect the portions of the site on the north and west sides which will be exposed to wave action and erosion when the water reaches the 4-foot elevation.

Orcoquisac Camp and Prehistoric Site, $41 \mathrm{CH} 22$

\section{History}

This site was first occupied in prehistoric times. It is also thought to be the site of the Orcoquisac encampment when the Spanish mission and presidio were in operation (see Fig. 25).

\section{Archaeological Investigation}

The she17 midden site was first reported by Shafer (1966); it consists of a high she11 mound surrounded by a widespread scatter of shel1 over a large area. A bank along Lake Miller forms the northern boundary of the site. This bank ranges in height from approximately 0.5 to $2.0 \mathrm{~m}$. A stand of oak trees forms a canopy which provides shade over a short grass carpet on the mounded area (Fig. 27,a). The majority of the rest of the site is covered with grass, occasional bushes, and trees. Two pipelines traverse through or near the site from east to west. One cuts through the approximate center of the site; the other touches the southern border. Sma11 backpiles of dirt from animal burrows and some erosion have exposed Rangia clam shells, prehistoric pottery sherds, a small amount of lithic chipping debris, and bone.

The investigation was begun with a random surface collection and determination of the extent of the site. Exposed Rangia shells and other cultural remains were used to determine the extent of the site. Since the second site of the mission is located nearby, and since there was no noticeable break in the surface indications of she 11 and artifacts, the entire area was mapped as one site. 


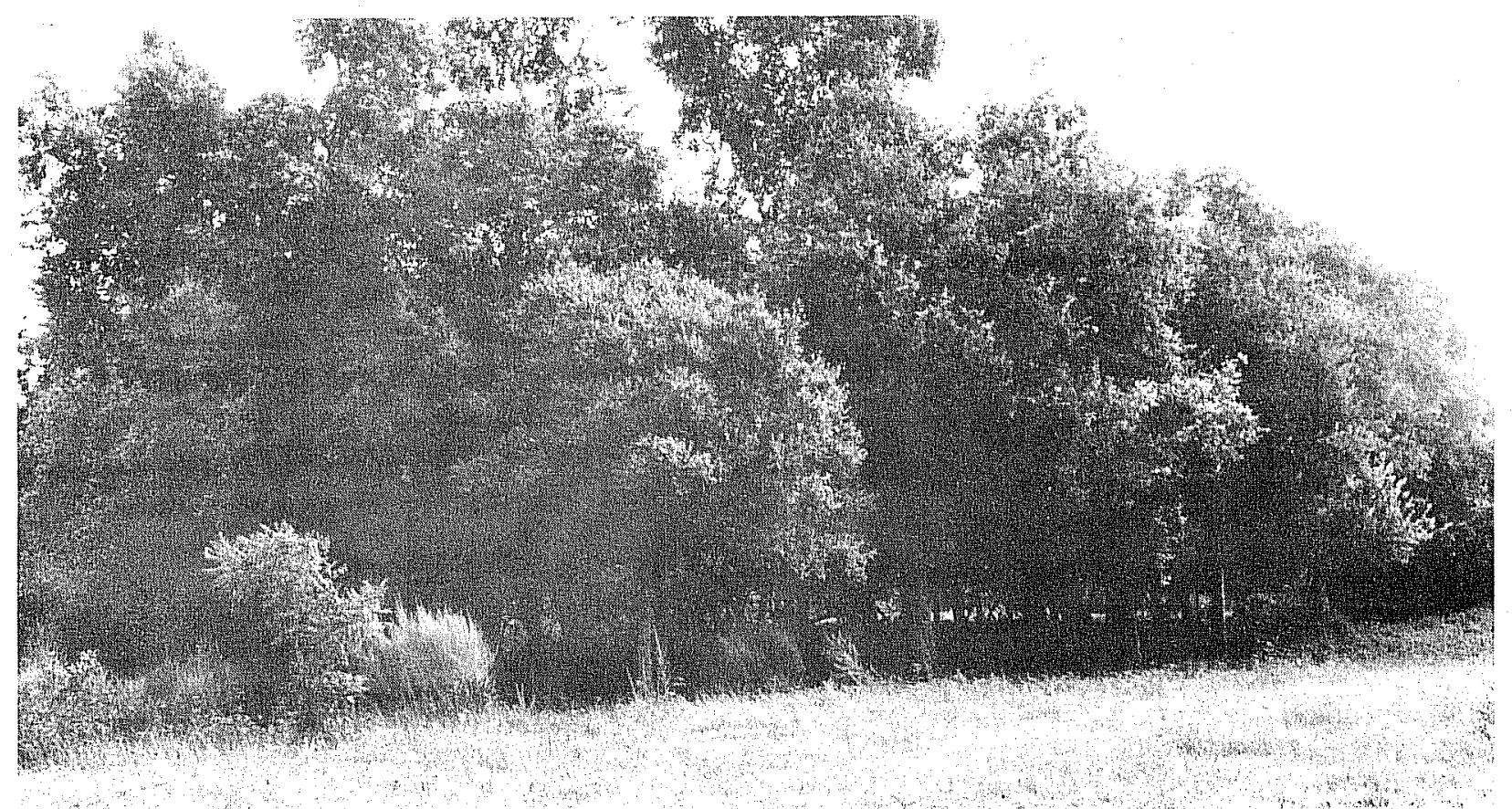

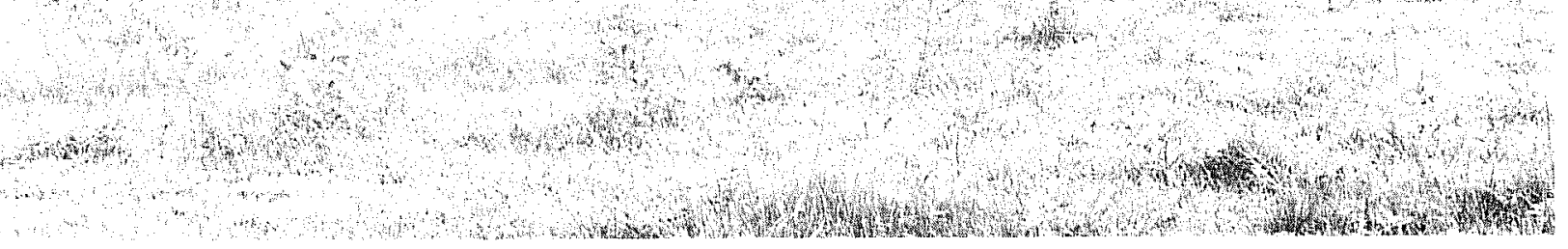

a

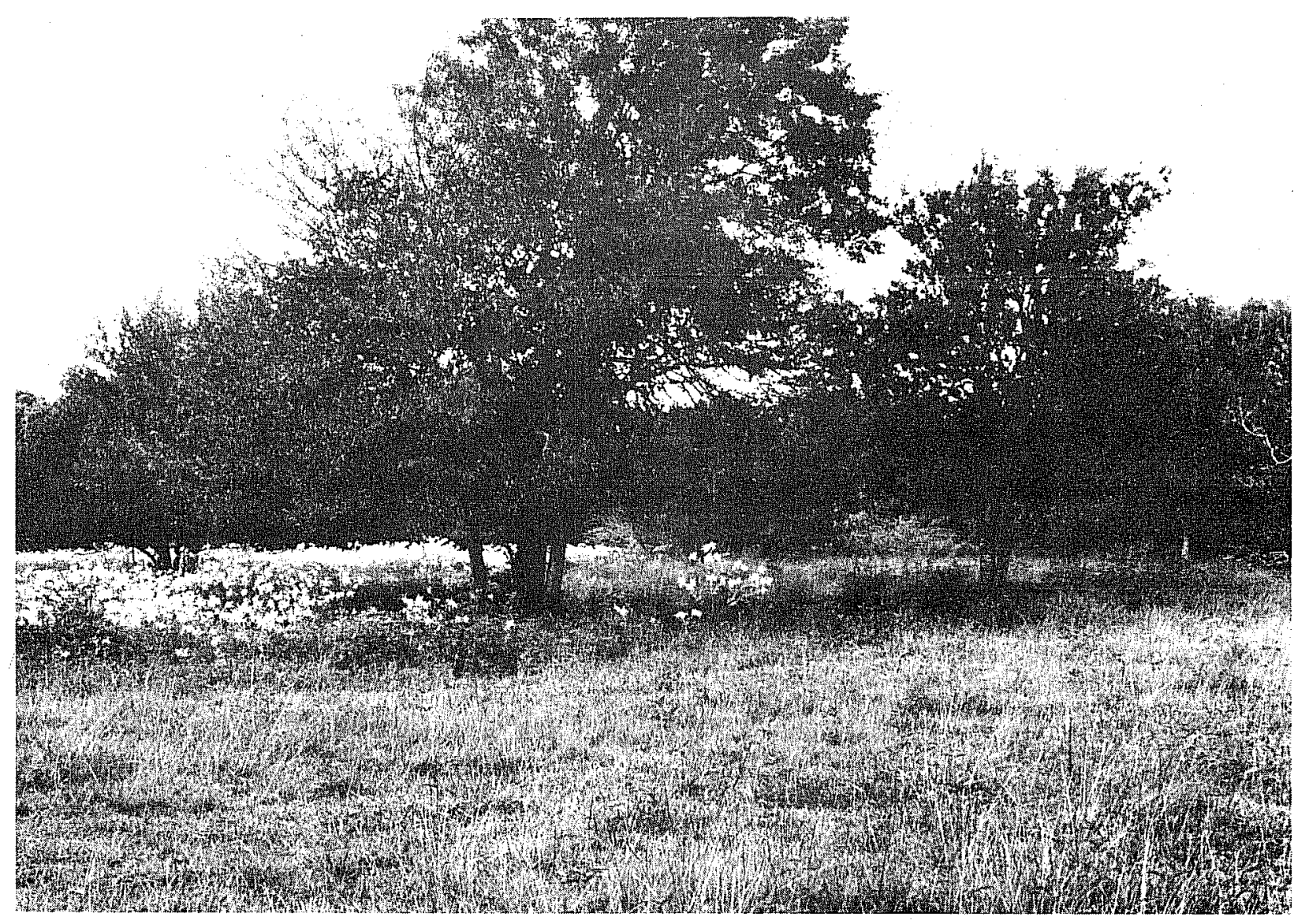

b

Figure 27. Views of $41 \mathrm{CH} 22$ and $41 \mathrm{CH} 54$. a, Indian camp site (41 $\mathrm{CH}$ 22) viewed from mission site; b, site of Mission La Luz (41 CH 54) from northwest. 
Flagging tape was employed to mark the perimeter of the exposed cultural remains. The entire surface of the sites was examined to insure that there were no gaps in the exposed cultural material that might suggest two distinct sites or a sterile area. No gaps were found. The boundary of the occupation area was then mapped (Fig. 28).

Information on cultural remains and depth of $41 \mathrm{CH} 22$ was sought with a shovel test in the approximate center of the shel1 mound, about $50 \mathrm{~m}$ south of the lake shore. It soon became apparent that shovel testing in the area chosen was extremely difficult and time-consuming. A compact layer of solid Rangia clam shells, 91 bone fragments, 27 prehistoric ceramic sherds (all but 9 were too small for analysis), and 2 chert flakes were recovered (see Prehistoric Sites Investigations section for further data). The shovel test yielded important data needed on cultural content of the site. However, the expenditure of time for this information seemed wasteful. Two crew members worked diligently for four hours and were able to excavate and screen the matrix from one test $30 \mathrm{~cm}$ in diameter and $50 \mathrm{~cm}$ deep. The large quantity of cultural material and density of the shell in the midden, therefore, prompted an experiment.

The depth of the cultural deposit was not determined in the shovel test. Also, further testing was needed in order to confirm the extent of the site, which had been tentatively determined from the exposed surface materials. A coring tool consisting of a long straight tube of automobile exhaust pipe ca. 3 inches in diameter crimped and sharpened at one end was loaned to the project by $W$. $L$. Fullen. At $10 \mathrm{~m}$ intervals on a north-south line, coring was substituted for the proposed shovel tests. (See Fig. 28 for approximate location of the 1ine of the shovel test and core tube tests.) Nine core tube samples were extracted and examined for changes in soil and cultural remains. As the coring progressed southward, the midden deposit became thinner, until in Test 7 the shell layer was from surface to $8 \mathrm{~cm}$. In tests 8 and 9 , no Rangia shel1 and no cultural material were found. The results of the testing agree with the exposed surface material used first to indicate the extent of site. The midden deposit appears to be more than $50 \mathrm{~cm}$ thick toward the lake shore and thins out progressively toward the south. A layer of sterile clay underlies the site.

A random surface collection and a $30-\mathrm{cm}$ diameter $\times 50-\mathrm{cm}$ deep shovel test provided a sample of 62 prehistoric sherds. Nine of the sherds collected from the surface and 12 of the sherds from the shovel test were less than $1 \mathrm{~cm}^{2}$ and thus eliminated from the total sample. Ten grog-tempered and 31 sandy paste untempered sherds were found. Eight chert flakes were also collected. One fragment of a blue glass bead was found on the surface in the pipeline right-of-way.

\section{Vertebrate Remains (Table 10)}

Shovel tests from prehistoric site $41 \mathrm{CH} 22$ yielded 70 bone fragments, of which $27(39 \%)$ are identifiable. Fourteen percent of the total bone recovered had been burned, and $11 \%$ of the identifiable bone had been burned.

Three vertebrate classes are represented in the identifiable sample: mammal, reptile, and fish. One deer element (left calcaneum) showed no signs of charring 
This page has been

redacted because it

contains restricted

information. 


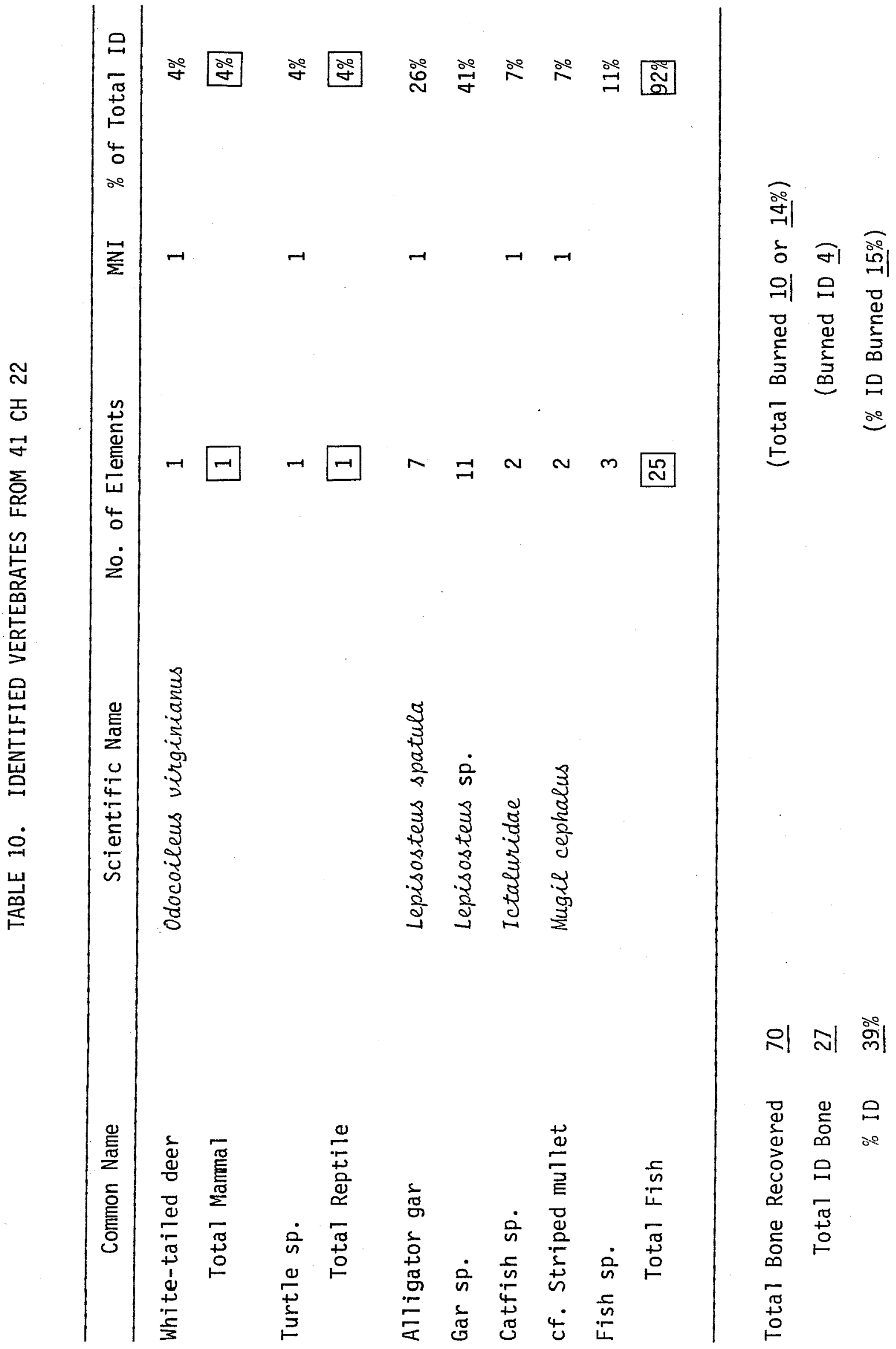


or butchering. One carapace fragment had no diagnostic characteristics for species designation. The fish elements, however, represented at least five varieties.

Seven large ganoid scales indicate the presence of an alligator gar, but 10 other scales are either too fragmentary or too small to be identified as alligator gar. A11 species of gar are found in the waters of Chambers County (Hubbs 1976). One vertebra must belong to a smaller species of gar, i.e., spotted gar, based on its small size. Another vertebra, although very large $(\ell=1.5 \mathrm{~cm})$, does not have gar characteristics. The deep concavity of the centrum resembles vertebrae of large mullet; striped mullet can attain a size of $76 \mathrm{~cm}$ and are known to inhabit Texas rivers and lakes far inland from the Gulf (Hoese and Moore 1977). A large dorsal spine fragment also compares well with a mullet of the same size as the vertebra. A smaller vertebra indicates another individual fish, but species is indeterminable. Catfish is represented by dorsal and pectoral spine fragments. The species of catfish cannot be determined, but a smal1 individual is indicated by the size of these fragments.

\section{observations and Conclusions}

As evidenced by the presence of grog-tempered and sandy paste untempered sherds, the occupation of the site may have begun as early as A.D. 1000 and extended to Spanish contact. The glass bead, coming as it did from a spot halfway between the shell mound and the mission in an area which has been undisturbed, cannot tell us anything about $41 \mathrm{CH} 22$. No surface evidence has so far been found to delineate the area where the historic Orcoquisac encampment would have been located.

The effect of the 4-foot water elevation in this area will be to bring the water to the foot of the bank, where undercutting by wave action will cause gradual collapse of the shell mound site into the lake.

\section{Recommendations}

The slope of the bank at this point is more gentle than that along site $41 \mathrm{CH} 62$, and the erosion will be more gradual but no less destructive in the long run. Some form of protection for this site from such erosion should be undertaken before the water level rises in the reservoir.

Mission Nuestra Señora de 1a Luz (second site), 41 CH 54 (Fig. 27,b)

\section{History}

The general history of Mission La Luz in connection with the rest of the Spanish/ Indian complex has been related in Section III. In order to determine the impact that the proposed reservoir would leave on the mission site, it was imperative that the extent of the compound be known. A search was therefore conducted in archival sources for maps, plans, and descriptions of the mission during the time it was located on this site, from 1759 unti1 1772. 
The earliest description found is that of Fray Abad in 1759, when he noted that the new mission was made of hewn wood and beaten clay, with four arched portals (see pgs. 46,47). The only information available on the buildings constructed is that which can be inferred from an inventory made eight days after the mission was totally destroyed by a hurricane (Rivera 1768). The furnishings and articles recovered from each of the buildings are 1isted. From this we see that there was a church, a "house" (for the padres), and a kitchen.

The buildings were probably rebuilt on their original foundations after the storm. A map of EI Orcoquisac done in 1767 (Fig. 25) shows three buildings, of which one is identified as the church. In 1768 Padre José Marenti reported the following buildings: one church, $12 \times 7$ varas, covered (roofed?) with shingles and plastered mortar, and whitewashed; a sacristy of the same materials; a cemetery; a house, 23 varas long with a hall and two cells, a porch, also plastered and whitewashed inside and out, and covered with shingles; and a kitchen. The mission square was 21 varas (ca. 57 feet or $17 \mathrm{~m}$ ) wide (Marenti 1766). Apparently a few modifications and additions had been accomplished, but there were still three basic buildings. No mention is made of structures on or near the lake shore.

Evidently since the mission was built near an established camp, no attempt was made to build dwellings for the Indians or to bring them into a communal life, as was done in the missions on the San Antonio River. Perhaps this is one of the reasons why so little progress was made in converting the Indians to the Spanish way of life.

\section{Archaeological Investigations}

The surface survey described above failed to find any Spanish Colonial artifacts on the mission site. This was surprising, since a survey done in 1966 yielded numerous sherds of majolica and other Spanish artifacts from a limited area on the top of the hill where the mission was located (Fullen 1966).

In order to determine the northern boundary of the mission and to assess what effect the reservoir would have on the site, a row of shovel tests was dug from the high water mark on the edge of the lake south through the pipeline easement and onto the mission site (Fig. 28). The average depth of these tests was $60 \mathrm{~cm}$. In each case, Rangia she11 was encountered near the surface and continued to ca. $60 \mathrm{~cm}$ deep on the slope, tapering off to $20 \mathrm{~cm}$ in the mission area.

Historic artifacts recovered were limited to one sherd of ironstone, two fragments of olive green bottle glass, one square nail, and a concentration of red, burned clay fragments which resemble brick. Similar late 19th-century artifacts were found in this area during the surface survey. Prehistoric sherds recovered from the tests included four unidentified, four grog-tempered, and three sandy paste untempered sherds. Two chert flakes were also found. 
Vertebrate Remains (Table 11)

On1y 60 bones were recovered from nine shovel tests at $41 \mathrm{CH} 54$, a historic Spanish mission site. Of this total, 10 were identifiable to vertebrate class and/or species. Only large mammal and large fish elements were recovered.

Large mammals are represented by one tooth enamel fragment from an immature deer, which may not be associated with the human occupation, and a right ulna from a cow. Both ends of the ulna have recent breaks and show some indication of recent gnaw marks along the radial scar; however, the lateral side has three pitted areas characterized by old, short, V-shaped cuts hatched several times in one spot. Three small crescent-shaped cuts also lie nearby. Other isolated marks are indistinguishable from gnawing marks.

One of the alligator gar scales has at least two tiny angled cuts at one end. This scale was recovered from shovel test (ST) 7 along with a vertebra fragment from the same species. Three gar scales from ST-3 are too fragmentary to determine species. A large vertebra also from ST-7 is from another large fish species, most likely the flathead catfish or a large blue catfish, both of which are found in the waters of southeast Texas (Hubbs 1976).

\section{observations and conclusions}

Apparently the lake shore between the mission site and Lake Miller was not used for any particular purpose during Spanish times, although it was involved in some way with a late 19th-century occupation. As at $41 \mathrm{CH} \mathrm{57,} \mathrm{the} \mathrm{entire} \mathrm{area}$ appears to contain a layer of shell and cultural material connected with the prehistoric occupation of the she11 mound nearby.

The rise in the water level from the proposed reservoir will not directly affect the mission site. However, the increased use of the area may bring problems with looting if the history of the site becomes well known. Some method of controlling access to this site should be considered, or a plan should be formulated for monitoring the use of the area.

Davis Farm Site, $41 \mathrm{CH} 245$

\section{History}

Located within the Thomas Rankin survey, this site was acquired by William J. Alston in 1858. His daughter married G. C. Davis (Chambers County Sheriff from 1872 to 1890), and they eventually inherited the property. Davis built a house, a barn, and other outbuildings on the south shore of the lake some time in the 1870s. The family moved into a new home on the south end of the property ca. 1890, and the old homestead gradually fell into ruin (Octavia La Four, personal communication). 


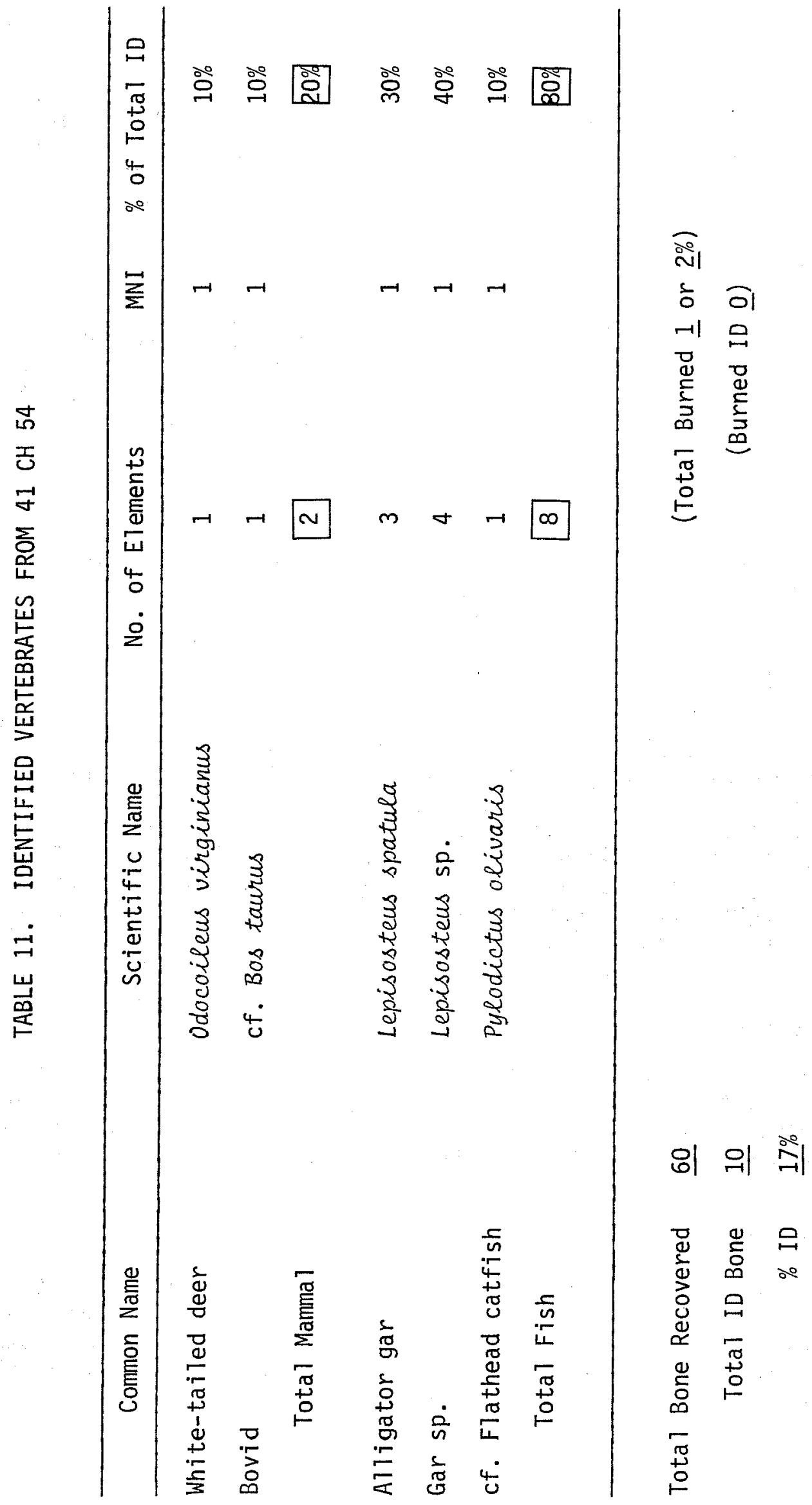




\section{Archaeological Investigation}

The house and barn were located on a high point just east of $41 \mathrm{CH} 22$ in a mott of very large, old trees. A surface examination was not able to find any structural remains in place, although an occasional brick can be found on the surface.

\section{Recommendations}

The slope of the lake bank at this point is gradual, and the higher elevation of the water will not affect the site. Since this site is already protected through its location within a Historic District, no further designation is necessary. While the site is of importance to the immediate family, it has no particular historic significance; and we recommend no further work.

Presidio San Agustín de Ahumada (second site), $41 \mathrm{CH} 53$

The history of the site has been covered in Section III and in Tunnell and Ambler (1967:5-16).

\section{Archaeological Investigation}

Investigation was limited to an inspection of the site in order to determine the possible effects which the proposed reservoir will have upon it, and to assess how much of the original site may remain. The hill upon which the presidio was built was aimost completely removed to be used as fill for the construction of Interstate Highway 10 in the 1950s. In 1966 archaeological testing was carried out at the site under the direction of Curtis Tunnell and Richard Ambler, and its tentative identification as the second location of the presidio was confirmed (Tunnell and Ambler 1967). No Spanish or Indian artifacts were found on the surface.

\section{observations and Conclusions}

The elevation of the remains of this site (over $15 \mathrm{ft}$.) will preclude its being endangered by intensified flooding or erosion from the reservoir. However, there is constant traffic by local fishermen across the site and public dumping of trash in the area. No recent potholes were observed.

\section{Recommendations}

Despite the fact that most of this site has been eliminated, the 1966 excavations showed that there is still much to be learned from the site. The creation of the reservoir will attract more people to the area. Access to the water through this site should be controlled or prohibited by a locked gate. This should also put an end to the dumping in the area. 
SHIPWRECK IN LAKE MILLER

In the early 1800 s Jean Laffite and his brother Pierre were engaged in a variety of illegal activities, including smuggling and piracy, in and around New Orleans. In 1812 they fought beside Andrew Jackson in the Battle of New Orleans and, as a result, were pardoned by President James Madison for previous crimes against the United States. In 1817 Laffite left Louisiana and established a town he called Campeachy on GaTveston Island (Wooten 1898:108; Fehrenbach 1969:127-128).

Within a few months, more than 1,000 men joined Laffite, and for the next four years copious smuggiing and piratical endeavors sustained the settlement. Laffite also engaged in the slave trade, a highly successful venture in the early 1800s. In less than a year a lucrative maritime trade network was established with New Orleans and other ports, including Boston (Hayes 1974:46).

Laffite's acts of piracy eventually led to his forced abandonment of Galveston Island. He reportedly permitted his men to seize and plunder Spanish ships only, but in 1821 the United States government requested that Laffite abandon and destroy Campeachy. An American vessel was plundered and sunk in Matagorda Bay, and Laffite's men were held accountable (ibid.:60). Lieutenant Kearney of the United States Navy was sent to Galveston Island on the brig-of-war Enterprize to enforce the withdrawal from Campeachy. Laffite entertained Kearney in royal fashion and attempted to persuade the naval officer of his allegiance to the United States. But Kearney carried out his orders, and in May 1821 Laffite burned Campeachy and left on the Pride with a crew of 60 men (Hayes 1974:62).

It is believed that, during the four years of Laffite's reign of piracy along the coast of Texas, many millions of dollars in gold and silver and other valuables were seized by his men. Numerous legends recount that some of the loot lies buried in the sands of coastal Texas. One of the most intriguing tales concerns the submerged remains of a ship in Lake Miller in Chambers County (see Fig. 15). For more than a century local history has purported that the ship is one of Laffite's treasure-Taden vessels.

One of the earliest published accounts of the ship concerns the life of Josephine Joseph and her reflections of the Galveston area in the last half of the 19th century (Mouton 1900). On Ju1y 4, 1859, the Joseph family planned a picnic along the banks of Lake Miller. Prior to the picnic the family members discussed various legends concerning the pirate Laffite. Local history suggested that Laffite often eluded pursuers by sailing up Galveston Bay to the Trinity River and then into Lake Miller. "He found here so secure a shelter that it became a kind of rendezvous till at length it was discovered, and being hotly pursued he was forced to sink his treasure-laden ship and escape as best he could..." (Mouton 1900:137-138). Upon arrival at Lake Miller, Josephine and the others located a tree which bore three man-made notches. This tree supposedly marked the location of the sunken treasure (ibid.:140-141).

In the 1890s Edward H. Sherman walked on the deck of the ship when it was only 1-1/2 to 2 feet under the silt. Sherman determined that the ship was about 60 feet long and had a flat deck. Because he had heard that Laffite's ships 
were sheathed in meta1, he checked for a seam but found none (sworn testimony, W. N. Sherman, February 2, 1978). W. N. Sherman, son of E. H. Sherman, testified in 1978 at the age of 89 that he could locate the site of the submerged vessel "using for bearings a shell bank on each side of Lake Miller." Partlow $(1974: 51)$ recounts that $W$. N. Sherman's great-grandfather, Jacob Havens Sherman, Sr., discovered the ship in 1850 slightly covered with silt and marked the location by driving a spike into a nearby oak tree.

Several sources attribute the ship to Laffite's departure from Galveston Island. According to Mrs. Julia Duncan Welder, the vessel was scuttled after the pirates abandoned Campeachy and was chased by a United States revenue cutter (Julia Duncan Welder Collection, Sam Houston Regional Library and Research Center, Liberty, Texas). According to Mrs. Welder, "The pirates had many friends along the Trinity, there was an entente cordiale between they and the settlers, where they often came to exchange goods, and 'pieces of eight,' for bear meat, venison, beef, hides, tallow, honey, skins and furs, and other commodities." Mrs. Welder also stated that she had visited E. H. Sherman, who told her that his grandfather, Jacob Havens Sherman, Sr., had walked upon the deck of the slightly submerged ship.

Carroll Lewis has suggested that the sunken ship is the Pride, the vessel on which Laffite departed Galveston. According to Lewis (1977:32), Laffite carried five bearskins of gold onto the pride and planned to bury the gold near Galveston Bay, but the ship sprang a leak and sunk near the mouth of Lake Miller before the treasure could be removed (ibid.).

In 1938 the ship was just below the surface of the water and the entire length was visible. Since then the lake has silted in and covered the vessel with mud (John Howells, personal communication).

In 1940 G. C. Chambless, Jr., and B. F. Williams requested a permit from the General Land Office of Texas to salvage the vessel, but the request was denied (Partlow 1974:51). The bow on the northwest end was approximately six feet deep, while the opposite end was 10 to 12 feet deep (G. C. Chambless, Jr., personal communication).

In 1949 B. J. Krigar and Leo T. Behne, with the aid of E. H. Sherman and his sister, Mrs. E. H. Clark, located the ship with a metal detector about 200 feet from the bank of a narrow channel that connected Lake Miller with the Trinity River (Partlow 1974:51). The project was abandoned because of legal problems.

Referring to The Journal of Jean Laffite (Laffite 1954), John Howells reports that in 1818 Laffite sent workmen to repair storm damage to his fort near the mouth of the Trinity. The fort was probabiy established to protect vessels and crewmen and was a base for repair and maintenance of vessels. Howells, citing The Journal of Jean Laffite (ibid.), states that the fort was $20 \mathrm{~km}$ from the Trinity River and $45 \mathrm{~km}$ from Galveston. Recently, structural remains have been found on Cedar Point, 13 miles west of the mouth of the Trinity and 28 miles north of Galveston. The wal1s, made of 10gs, mud, and she11, are eight feet thick. Howells is conducting investigations to determine if the site can be linked to Laffite. If this was indeed one of Laffite's forts, it increases the possibility that his vessels would have occasionally sailed up the Trinity, or that a hurricane could have blown one that far inland. 
It seems to be an indisputable fact that there is a sunken ship in Lake Miller. There is a distinct possibility that it might have been one of Laffite's ships, but no proof has so far been found for this allegation.

The construction of the proposed lake will have little if any impact on the site of the submerged vessel, except to bury it gradually deeper in silt. If a magnetometer survey is conducted on site $41 \mathrm{CH} \mathrm{57,} \mathrm{it} \mathrm{might} \mathrm{be} \mathrm{interesting} \mathrm{to} \mathrm{also}$ attempt to locate the exact site of the wreck for future reference.

\section{THE TOWN OF WALLISUILLE}

In the early 1850s the settlement of Wallis Hill consisted of a few scattered houses, a wharf, and the Union Saw Mill operated by Clarke and Kilgore (Galveston Weekly News 1853:1). About 1854 Solomon and Daniel Wallis, sons of early settler E. H. R. Wallis, began planning a town on their property (Fig. 29) and hired Hugh Jackson, local lawyer and surveyor, to lay out a formal plan (John Middleton, personal communication). This was to become Wallisville.

In 1858 Chambers County was created from parts of Liberty and Jefferson Counties, and the new town of Wallisville was named the county seat (Partlow 1974:143). In 1859 a wooden courthouse was built on the courthouse square, and Wallisville got a post office (ibid.:145). A school was built in 1860 (John Middleton, personal communication).

Civil War times were hard in Chambers County, since the people were completely dependent upon shipping for the basic necessities of life, and trade through Galveston was cut off. There was enough food, for they grew what they needed, but commodities like wheat flour and coffee were rare and expensive. The women went back to carding, spinning, and weaving as their grandmothers had done, and inventiveness and resourcefulness were the order of the day (Harry 1940:26).

The recovery after the war was slow and difficult. In 1875 the courthouse burned, destroying a11 the county records. The top floor of the La Four Hotel was used for a courthouse and district courtroom for about a year, until a new courthouse could be built (ibid.:23). By 1876 Wallisville had a population of 200, a good school, 50 homes, and three stores (Harry 1940:54).

As the town became more prosperous, in 1886 a contract was let to build a stone, brick, and cement courthouse (CCCCM:A,458), and a brick jail in 1896. By 1898 the town consisted of numerous fine homes, the McManus Cotton Gin (wallisville Age, December 22, 1897), Stephens and Kilgore Store (ibid.), the Wal1 is and Murphy Store and another merchandise store, two hotels, a newspaper, the C. R. Cummings Export Lumber Company, the Wallisville Lumber Company, and two lawyers' offices; it had a population of 728 (Texas Almanac 1904:43). By 1903 Wallisvilie also had a shipyard large enough to build ocean-going barges, and two artesian wells had been dug (ibid.:232-233).

The big social event of 1906 was the opening of the new roller-skating rink (Liberty Vindicator, August 24, 1906). Despite the new prosperity, Tivestock stil1 ran loose in Chambers County and hogs were becoming a nuisance in town. Wallisville voted a hog control law, which incensed many county residents. As a result, an election was held to remove the county seat to Anahuac. Wallisville 
lost the election, and the county seat was moved in 1908 . Just seven years later, in 1915 , a tremendous tropical hurricane inundated the town of Wallisville, swept away numerous homes and business establishments, and permanently damaged others. Eight feet of water stood on the ground for a week, and $100 \mathrm{mph}$ winds buffeted the area for several days (Harry 1940:55).

Although the town gradually repaired and rebuilt the damaged structures, it never fully recovered from the storm. The commercial emphasis in the county by this time had transferred to Anahuac. In 1935 oil was discovered across the valley at Mont Belvieu (Webb 1952:327), which brought new prosperity to that area but did 1ittle to help wallisville. By the late 1950s the town had two churches, two stores, a filling station, a post office, a fish market, a wharf and shell company, and 25 homes (John Middleton, personal communication).

In 1966 and 1967 the land on which the town of Wallisville was located was purchased by the U.S. Government for the Wallisville Lake. Most of the buildings were moved to other locations, and the rest of the town was dismantied and removed. A large portion of the town site was excavated in order to build a dike at the eastern end of the site (Fig. 29).

Courthouse and Jail, $41 \mathrm{CH} 228$

Built in 1886 in the center of Block 7, the impressive brick courthouse was a local landmark for many years (Fig. 30). The land was donated to the county by D. B. Wallis with the stipulation that it return to his heirs when it ceased to be used for this purpose (CCDR 69:280,281,283). The second-floor courtroom was not only used for county business, but reguiar dances were also held there (Wooten Sisters 1973). In 1896 a brick jail with a hanging tower was constructed just east of the courthouse. The jail was partially dismantled in 1908 . The courthouse was torn down and the bricks sold in 1948 (John Middleton, personal communication). From that time to the present the site has been exposed to the ravages of time and local scavengers and curiosity seekers who have carried off most of the bricks and the other artifacts which once remained. Vandalism has been especially bad since the abandonment of the rest of the town site and the rapid growth of trees and brush in the area.

\section{Archaeological Investigation}

The courthouse square has recently been cleared of trees and underbrush under the direction of John Middleton in an attempt to limit vandalism and to aid in further research on the site toward the aim of reconstructing the courthouse and jail.

Other than a surface inspection of the ruins of the buildings, no work was done at this site, since the University of Houston plans to conduct test excavations and contour mapping on this block in the near future (Brown 1979). At that time a search will also be made to determine if traces remain of an earlier courthouse which may have stood on the block.

\section{observations}

It appears that the foundations of both the courthouse and the jail and hanging tower are still present and in good condition. Careful clearing of the wall 


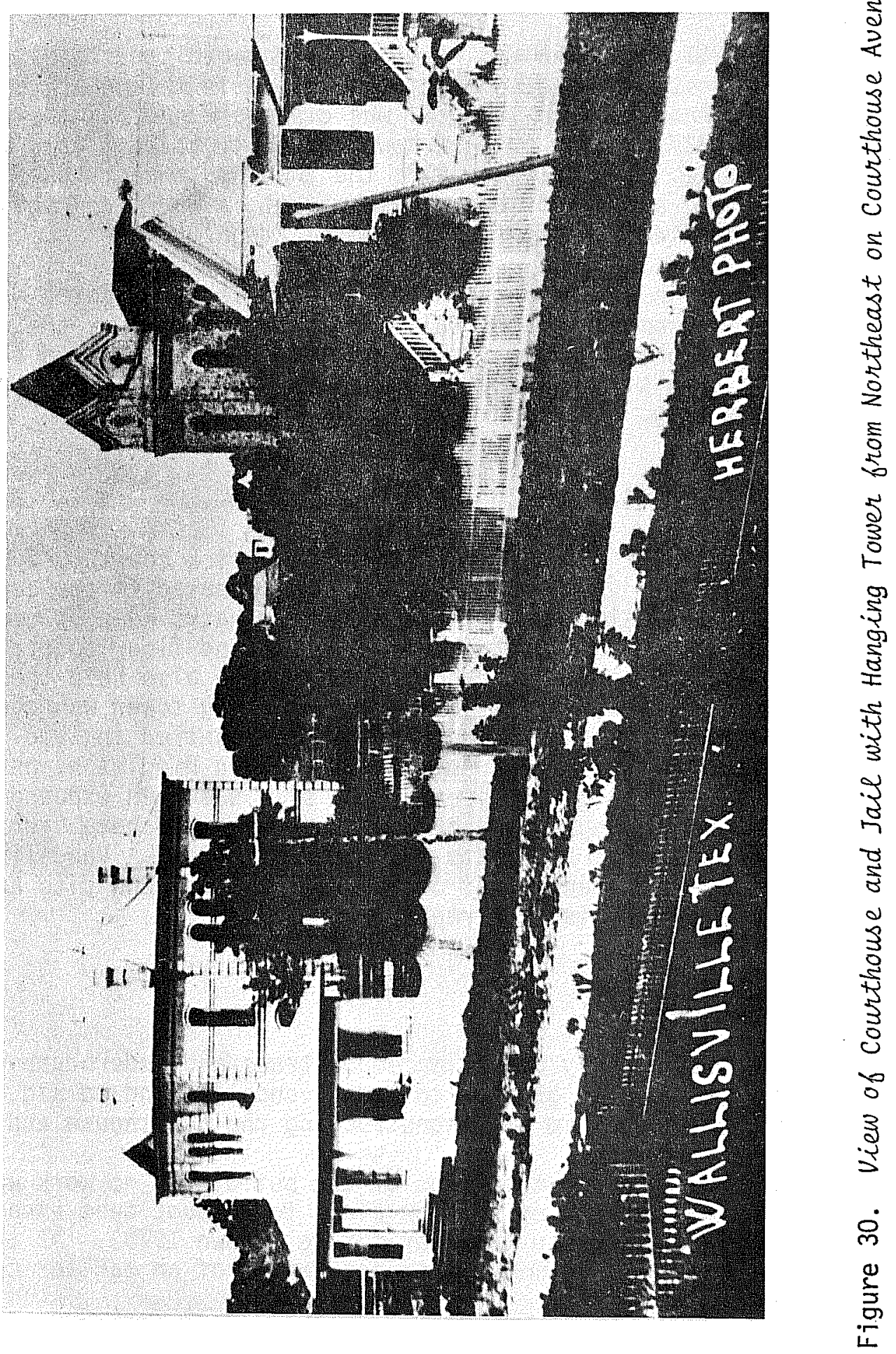


rubble should allow measured drawings to be made of the structures in preparation for the planned reconstruction of the buildings.

W. B. Gordon House Site, $41 \mathrm{CH} 241$

\section{History}

William B. Gordon spent his youth on the family's plantation on the Trinity River, just south of Liberty (Gordon 1873-1879). In 1884 he married Lura Shelton and moved to Turtle Bayou (Gordon Family Record). Sometime between 1881 and 1893 the Gordons moved to Wallisville. Mrs. Gordon died in 1897, after which Gordon married Mary Hawkins in 1902 (ibid.). It was during this marriage that Gordon built a large, two-story frame house on Lots 11 and 12 in Block 3. Gordon was an influential man in the community, serving as county judge and tax assessor (Williams et al 1976). In 1910 he sold the property to Mrs. T. E. Calhoun (CCDR 2:671), and she in turn sold it to Dale La Four in 1916 (CCDR 7:176). The house burned in 1961 (V. M. Williams, personal communication).

\section{Archaeological Investigations}

Approximately half of the area included in Lots 11 and 12 has been eliminated or seriously disturbed by borrow operations in connection with the construction of the dike across the west edge of the town. The area is now densely overgrown with small trees and shrubs. A collection was made of some of the more diagnostic artifacts among the heaps of trash which appear to have been dumped in the remaining part of the site: (Table 12). Although there are a few fragments of objects which may have been connected with the occupation of the house, such as a porcelain doll's head, some pressed glass, and a few sherds of ironstone and porcelain tableware, the majority of this collection is recent and reflects the dumping which has been going on in the area since the town has been deserted.

\section{observations}

Evidently there is a layer of recently dumped material which overlays whatever may be left of the Gordon house site. However, there appear to be some earlier artifacts present on the site, and it may be that traces of the original house foundation remain in the ground.

T. J. Shelton House Site, $41 \mathrm{CH} 237$

\section{History}

The lot where this house stood was acquired by Charcilla Van Pradelles Chambers (Mrs. Sandon) from her father in 1873 (CCDR:A,96). By 1876 she and her husband owned a 11 of Block 8 (CCDR:A,100;A,350). During this time, Chambers built a two-story frame house (Fig. 31) on Lot 7, facing south onto Courthouse Avenue. 


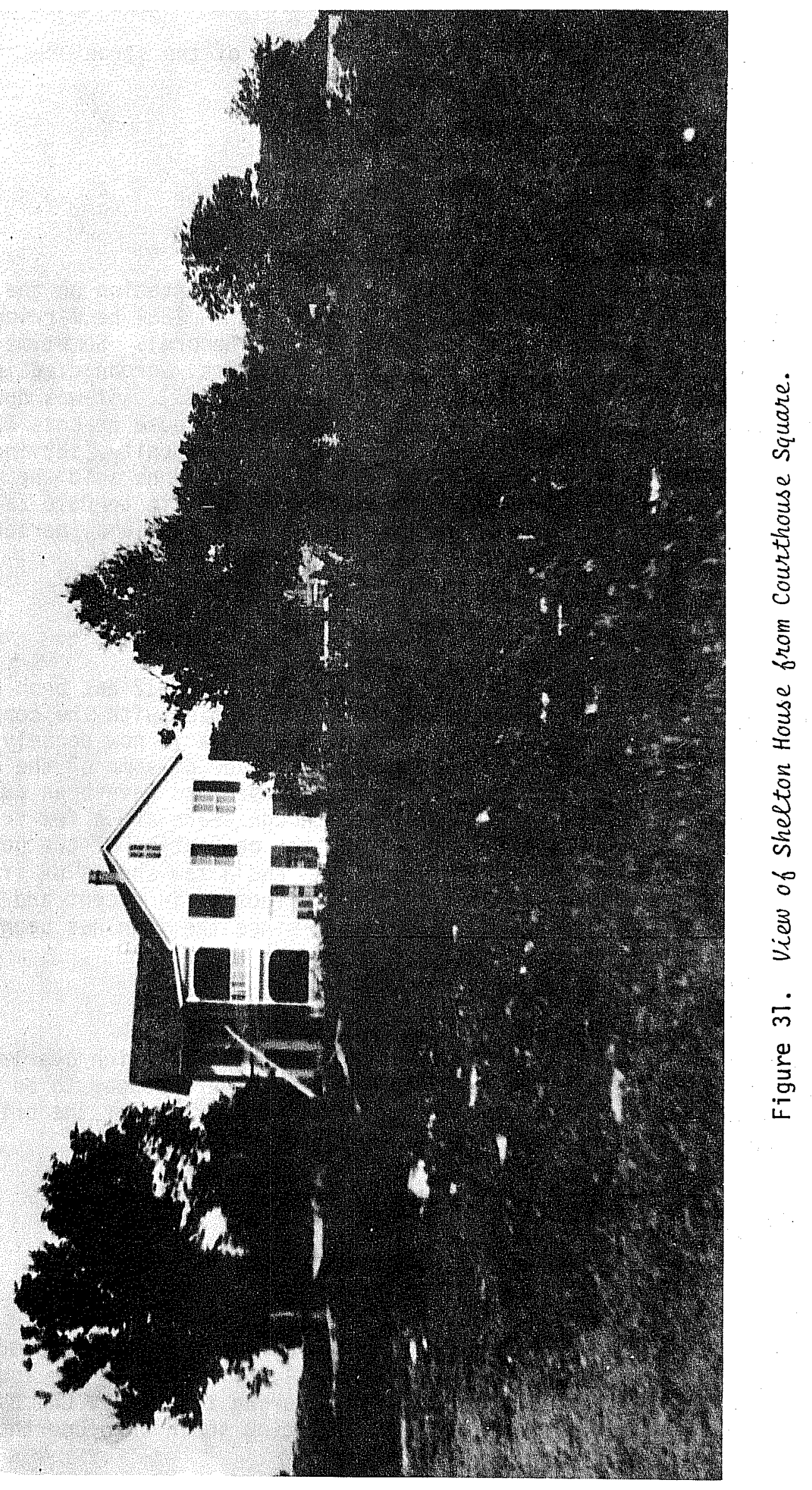


TABLE 12

ARTIFACT PROVENIENCES

WALLISVILLE PROJECT

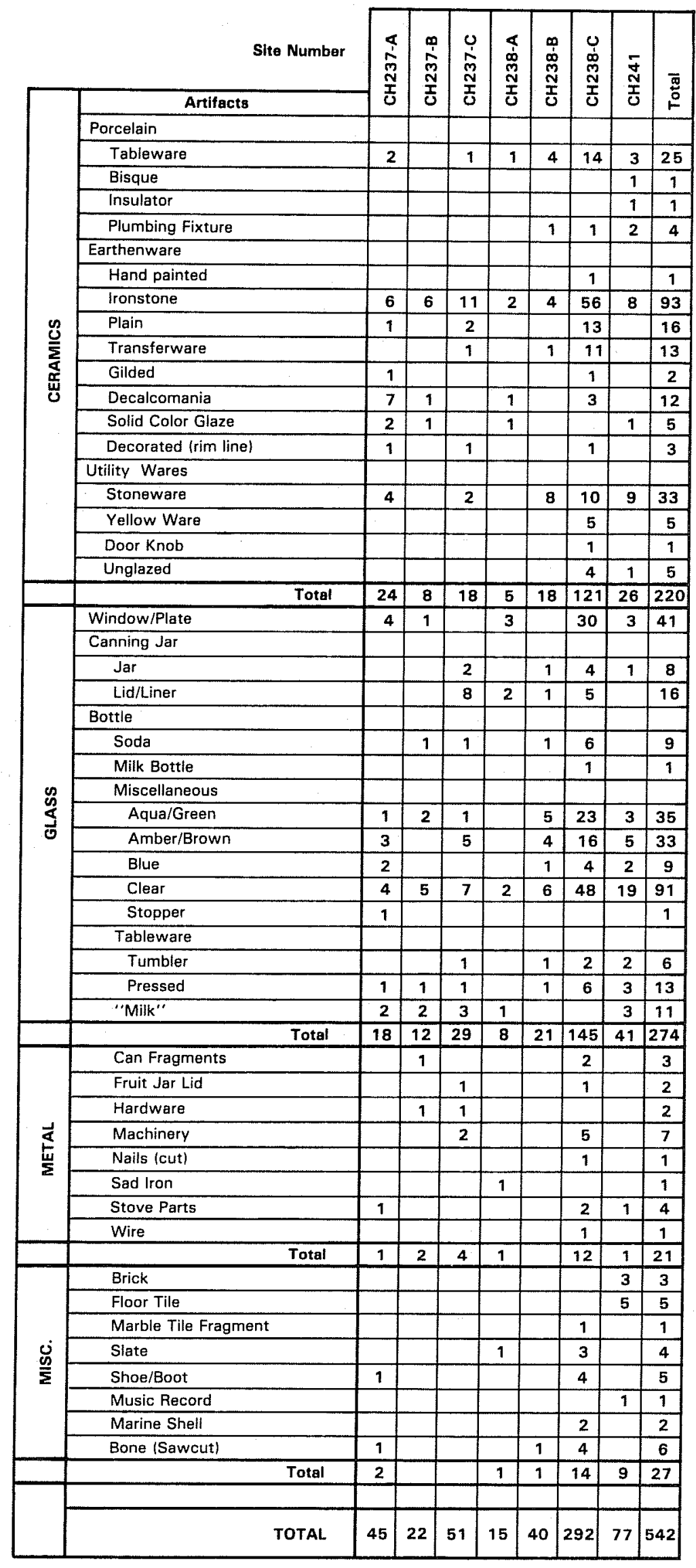


The entire block was sold to R. D. White in 1888 (CCDR:E,401), then by white to Lizzie Mayes ((Mrs. T. J.) Shelton in 1897 (CCDR:J,148). The Sheltons leased the house to Jesse Remick in 1905 (CCDR:S,92). Remick worked at the Cummings Mil1. In 1912 they leased it to William A. Robertson, father of the treasurer at the mi11. The house was finally dismantled in 1948 and the pieces taken to the town of Louise, where it was rebuilt (John Middleton, personal communication).

\section{Archaeological Investigation}

The site on which the house was located is now completely overgrown. It still contains numerous brick piers, and several large trees mark the corners and fence lines. The investigation consisted of clearing the surface enough to reveal the location and patterning of the piers and other debris, then making a measured sketch map of the house site (Fig. 32) and the immediate surroundings. Location of lot lines was accomplished by estimating the edges and then the center of the roads, shown on the maps to be 80 feet wide (Work 1945; Ha 11 1949), then measuring from the center line. A rather large area of scattered, broken bricks was found at the center of each end of the foundation, probably the remains of the two chimneys visible in the photograph. No doubt most of the bricks which once remained on the site have fallen prey to scavengers.

A thorough search was carried out to discover the location of trash dumping areas. A row of small saplings across the rear of what was probably the cultivated backyard of the house indicated where a fence once stood. The most intense trash dumping area was found to be just outside of this fence (Area A), with others (Areas B and C) to the east and west. In each case it appeared that trash had been dumped over a fence, spilling back into the yard in the process or spreading out later as the pile deteriorated and weathered. The area in the vicinity of the foundation was comparatively free of artifacts except for modern bottle fragments which have accumulated since the house was removed.

\section{Vertebrate Remains (Table 13)}

Surface collection at the site of a late 19th century home $(41 \mathrm{CH} 237)$ resulted in the recovery of 11 bone fragments of which 6 were identifiable. Two of three burned bones were identified as deer metatarsal fragments. One of these was burned black, but the other was only charred at one end. Faint scratches are noticeable in the middle of the latter, and these scratches are diagonal to the length and just outside the anterior groove of the metatarsal.

Reptile remains comprise $67 \%$ of the total identified bone collected. Two very large $(6.3 \mathrm{~mm}$ and $7.8 \mathrm{~mm}$ thick) fragments were identified as softshe 11 turtle. Two subspecies common to Chambers County are the midland smooth softshell and the pallid spiny softshell, both of which can attain a size of over $30 \mathrm{~cm}$ (Conant 1975). They are common in Gulf Coast drainage areas.

Evidence of American alligator was also collected from the site. Two distinctive scutes (spine-bearing dermal bones) were recovered. These large reptiles are native to this Gulf coast county. 


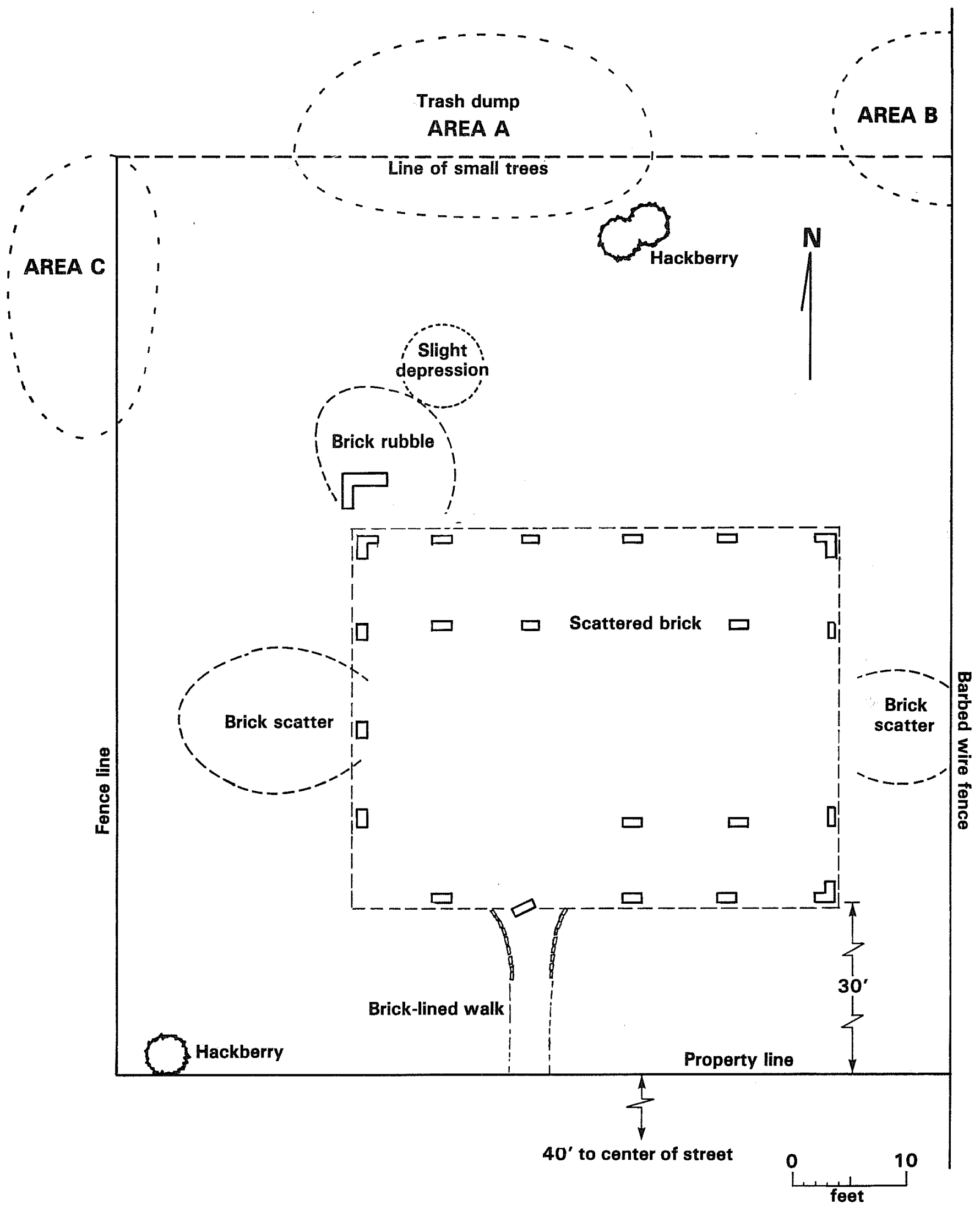

T.J. Shelton House Site Wallisville

Figure 32. Map of Shelton House Site. 


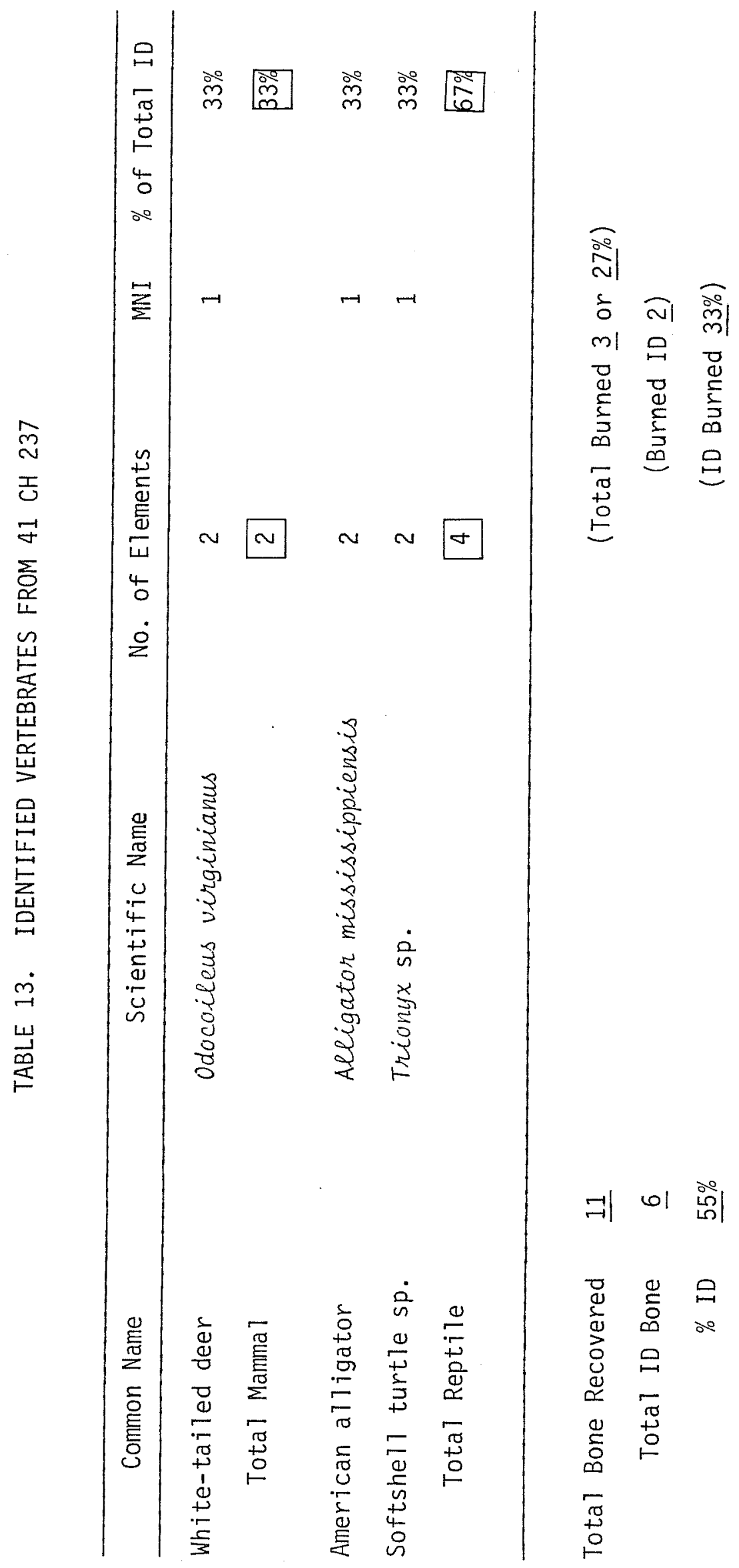


Observations

A comparison of the artifacts recovered from the various dump locations indicates that they were probabiy all in use within the same time period; at least there are no clear differences between them in terms of dating of materials (Table 12). The ceramics consist of plain white ironstone and molded earthenware of the late 19th century along with decal-decorated and plain-colored glazes of the early 20th century. Glass bottles are all machine-made and date to the post-1900 period. What stoneware is present bears late finishes such as Bristol and cobalt-colored glazes. Other artifacts found include a zinc lid, several "porcelain" liners and a glass lid for canning jars, a simple door hinge, fragments from a cast iron stove, and a threaded iron pipe coupling. Fragments of fine porcelain plates and a pressed glass salt dish suggest a fine table service befitting a socially prominent family around the turn of the century. More intensive archaeological and historical investigations would yield a great deal of information from this virtually undisturbed site on location of walkways and outbuildings, as well as additional artifacts representative of the late 19 th century.

\section{Block 9}

\section{History}

This entire block was originally acquired by Joseph La Four (CCDR 1872:A,61). The southern half was deeded to Seth Davis, his son-in-law, in 1888 (CCDR 1888: $E, 455)$.

The southeast corner is important to the town because it was the site of the La Four Hotel, which later became the Davis Hotel. To the west on Lots 11 and 12 stood the Davis store, dealing primarily in clothing and drugs (Chambers county Herald 1900). There was an orange grove directly behind the hotel (Wooten Sisters 1973).

\section{Archaeological Investigation and observations}

A surface survey was attempted, but thick ground cover and dense underbrush on the south half of the lot made it impossible to see the surface of the ground. The northern half of the lot is open under large trees, but no early structural or artifactual remains were present. A series of concrete slabs facing onto Walli is Street from Lot 7 indicate later use of the area, and there has been recent trash dumping near the road.

The southern half of this block should be one of the most interesting and important archaeological sites in the town. Unfortunately, in order to even begin to assess what remains there, it would be necessary to completely clear the surface of a dense growth of ground cover. The hotel site should yield important artifactual evidence about the life style of people who stayed in the hotel as well as of the family who ran it over a period of 40 years or more. The store and its surrounding area should also yield important artifactual and structural evidence concerning the arrangement, management, and stocking of such a store at the turn of the century. 
Dr. T. W. Shearer House Site, $41 \mathrm{CH} 238$

Lots 1 and 2 in Block 10, on which this house was located, have changed hands numerous times since it was acquired by John U. Raymond in 1881 (CCDR:C, 347). In $1887 \mathrm{P}$. B. Plotts acquired them (CCDR:E,159) and built on Lot 1 the following structure:

one Gin house and steam Gin comprising one ten horse power

Baxter Engine, one Sixty Saw Gillette Gin Stand, with one

Condenser and an iron Screen press, together with all belts, fixtures, attachments to the same (CCDR:E,259).

Evidently the business was not successful, since he returned the property to the original owner in 1889 (CCDR:E,470).

In $1887 \mathrm{Dr}$. Thomas $\mathrm{W}$. Shearer from Des Moines, Iowa, bought the drugs and medical equipment of the local doctor (Shearer 1944:4), Dr. John Raymond, who moved to Washington, D.C. (John Middleton, personal communication). In 1889 he bought "a three room cottage with a leanto kitchen" which was located in the center of a $120 \times 160$ foot lot. This would have been Lots 1 and 2, for they acquired Lots $3,4,5$ and 6 in 1898 (CCDR:J,153). Mrs. Shearer's (1944) interesting description of the house and grounds follows:

Our cottage was what they called a box house, but at odd times during our first spring in it, he battened it all inside and we painted side walls and ceilings. Also he made double doors between living room and dining room and an arch to the bedroom where we hung heavy portieres. Later, as our family increased, carpenters tore down the leanto kitchen and added two bedrooms, a pantry and kitchen; so you see he made us as comfortable as he could and we all loved HOME.

We beautified the yard and it was the admiration of all who saw it. A flowering pomegranite [sic] was already in the front yard. Pipes were laid from the windmi 11 tank al1 through the yard and into the latticed porch, where we installed a bath tub, the only one in town. Walks were laid and shelled from the front gate to the front porch, from there around the house to the south porch, out to the west gate and down to the wee house at the back end of the lot. A wide flower bed bordered the shell walks. We enjoyed studying the seed catalogue, ordering and planting annuals, bi-ennials, perennials, shrubsets, etc. We built a large grape arbor near the west gate on which grew luxuriously Delaware Black July Concord and white grapes. A rose arbor in front of the "wee" house was covered with pink bouquet climbers and the wild, shiny leaved Cherokee rose. These were monthlies and bloomed almost constantly.

Doctor brought in many wild plants from the woods and open country when returning from professional visits. In one corner of the yard we planted Spanish Dagger, cactus pear, etc. This we called our tropical corner. 
A hedge of wild peach was planted a11 along our 120 foot front and a hedge of Yupon along the west 160 foot border kept neatly trimmed. We had red, pink and white oleander, flowering quince, a couple of ponderosa lemons, a couple of loquates [sic], some kumquats also which bore we11. In the southwest corner of the yard we planted sixteen oriental plum trees of several different varieties, and yum, yum, were they good! He had a small hothouse built for me in the back yard, so that many plants that might have died in winter actually thrived and grew under the glass roof of the hothouse. Seedlings could be started early this way.

The yard in which the pecan trees grew, he made into a vegetable garden. Here he experimented in alfalfa, onions, cow beets and other plants....

Before enlarging our house, he had a neat two room office, a frame building, built in the NE corner of our yard facing the street and the courthouse. A large rose garden was planted between house and office. We had roses al1 the year except January....

The barn was in an adjacent lot which also contained several large bearing, paper shell pecan trees. This and three other lots facing Courthouse Avenue we later purchased. A year or so later we bought the two lots back of the house lot, and then the NE. corner of the block as a small pasture for the calves of the milk cows, thus giving us about three-quarters of the entire block. . .

The lots back of the house lot faced Main Street. We planted them in pear trees, and on the NE corner, built a large barn on which we erected a windmill. We enclosed the alley separating the north from the two south lots. The windmill supplied water to a trough for the horses and cows.

In 1907 the Shearers moved to Houston (Shearer 1944:16). Afterwards the house gradually deteriorated. The storm of 1915 swept it off its piers but the building survived. Later it became a cafe and barber shop run by Kit Carson Payne (John Middleton, personal communication). By 1941 there was no trace of a structure on the lot (U.S. Government Survey 1941). The property ownership, however, stayed in the Shearer family until the government acquired it in 1967 (CCDR:Z,881).

\section{Archaeological Investigation}

The Shearer house site today is overgrown with trees, but the area beneath is fairly open, making it possible to see most of the original yard area from the spot where the house once stood. The ground is covered with fallen leaves, but no grass cover is present.

A careful examination of Lots 1, 2, and 3 failed to 1ocate any architectural remains of the house. However, numerous shell pathways are still visible, and by mapping their location and referring to Mrs. Shearer's description it is possible to project where the house would have been located (Fig. 33). The 


\section{Courthouse Avenue}

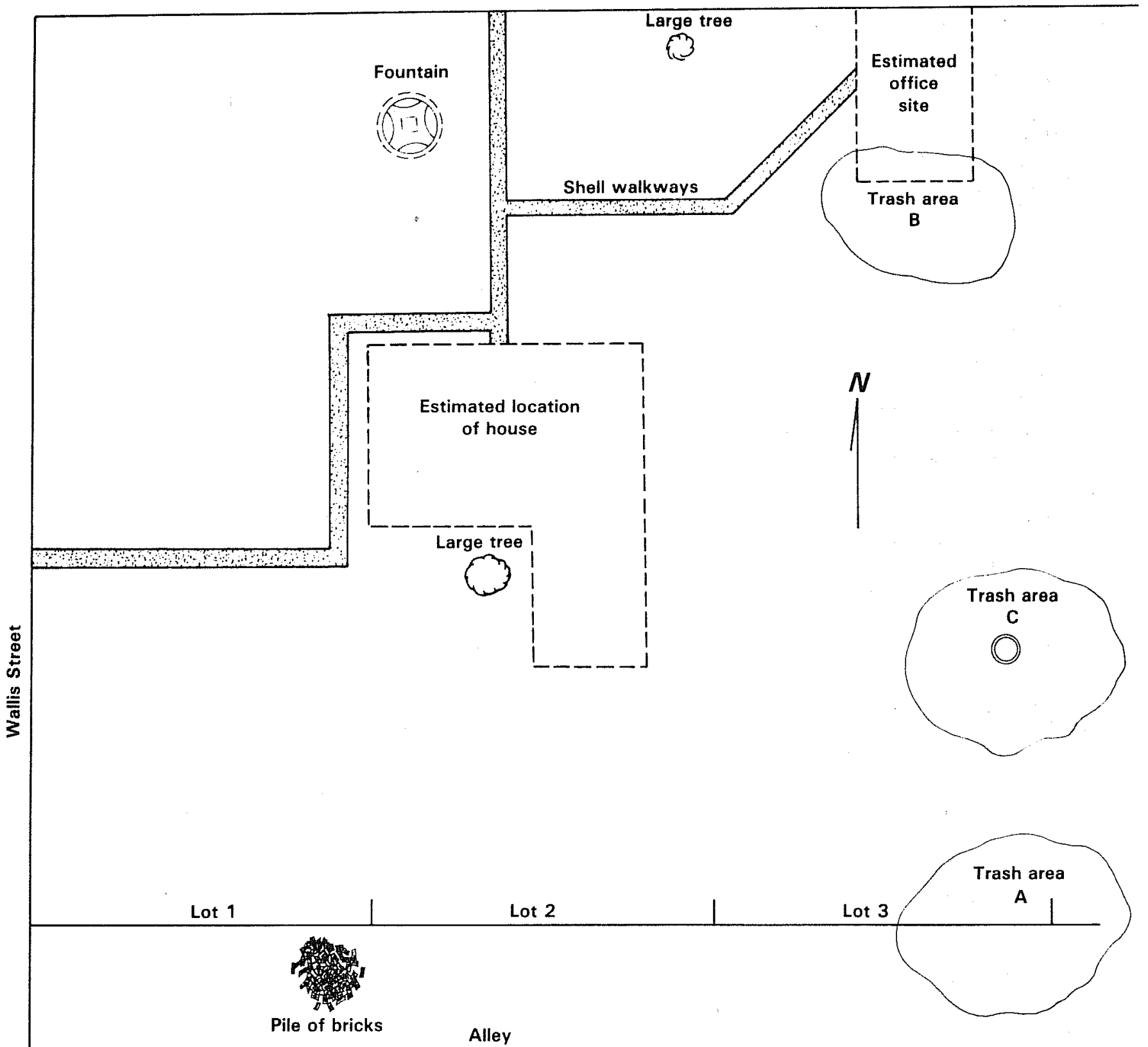

Dr. T.W. Shearer House Site Wallisville

Alley

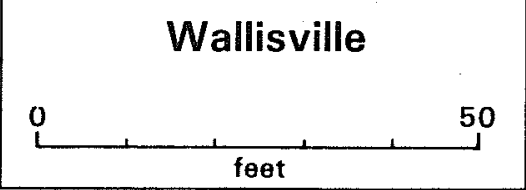

Figure 33. Map of Shearer House Site. 
presence of a very large tree with a low-hanging branch on the southwest side also helps to delineate the area where the house had to stand. Local informants still remember the brick fountain, the ruins of which are visible in the front yard.

The surface survey located a number of features in the area surrounding the house. An open area ca. $20 \times 30$ feet facing on Courthouse Avenue and east of the house site may be the location of the office Mrs. Shearer describes. The fact that one of the shell pathways leads to this site confirms that it was probably contemporary with the house.

Behind the house, within the area where the alley would have been, is an enigmatic pile of bricks. This could be the remains of the "wee house at the end of the lot" mentioned by Mrs. Shearer, although no shell pathway could be seen leading between this area and the house. It could also have been the watering trough mentioned by Mrs. Shearer.

To the southeast of the house site was located a deep, brick-lined hole approximately four feet across which was probably a well. Around this, trash was scattered in all directions. There was another area of trash dumping at the southeast corner of the lot. Each of these areas, as well as the "office" area, was selectively surface collected for diagnostic artifacts.

\section{Observations}

Although there were some minor variations in the assortment of artifacts collected from the different areas (Table 12), the differences do not appear to be meaningful for interpretation of the site. The bottles and ceramics are all typical of those found on sites occupied in the 1ate 19th and early 20th centuries. The slabs of slate suggest that the house had a slate roof. The cast-iron stove and doorknob fragments are also typical of this period. It is interesting that more bottle fragments and part of a stoneware ink bottle were found near the proposed office. While this distribution may be partly a product of the method of surface collection, it does suggest that the office could have been located there.

It appears that the artifacts around the "we11" are primarily kitchen-type materials, suggesting the location of the kitchen in the wing which projected to the south. This is confirmed by Mrs. Shearer's description of the later addition.

The presence of a well in this spot is confusing, since Mrs. Shearer describes a windmi 11 and water system in operation from the barn on Lot 11 . Since it does not seem 1 ikely that the doctor would have tolerated an open and unused wel1 in his yard, this may have been constructed after 1900 when Lot 11 was no longer part of Shearer's property. As of 1960 there was still no community water supply in Wallisville. The area was serviced by individual wells (Neyland 1960).

No trace was found on the surface of the steam gin operated on Lot 1 by Mr. Plotts in 1887-1888. The area was undoubtedly cleaned off and turned 
into a lawn by the Shearers as part of their landscaping efforts. This area may contain subsurface remains and should be further examined in the future.

H. R. Wa17 is House Site, $41 \mathrm{CH} 240$

\section{History}

Lots 11 and 12 changed hands a number of times in the early history of the town and were finally bought by Dr. Shearer sometime in the early 1900s. At this time he built a barn on the north end of Lot 11 and planted an orchard on Lot 12 . No mention is made by Mrs. Shearer of any structure standing on Lot 12 during their ownership. Dr. Shearer sold the two lots to H. R. and S. A. Wall is in 1913 (CCDR:4,218). The Wallises moved their large, two-story home from Deelyville to Lot 12 and set it up facing south onto Main Street (Fig. 34). The Wallis family eventually leased the house to others but retained ownership until the government bought the town site. The house was moved away in 1964.

\section{Archaeological Investigation}

Lots 11 and 12 are completely overgrown with trees and underbrush. Several large trees remain along the fencelines. Surface examination was conducted over the area, and a pattern of brick piers was cleared and their location mapped (Fig. 35). No trace of artifactual evidence was found anywhere on the lots during the survey. However, the ground cover was dense, and it was not possible to clear a sufficient area to efficiently examine the surface. This could be more profitably done in the winter when the ground cover is sparse.

\section{Observations}

The majority of the piers are constructed of locally-made brick, but in a number of cases this foundation appears to have been supplemented and/or reinforced by the addition of a course or an entire pier of a more recent, red brick marked "FERRIS." A few of this same type were found scattered around the Shelton house foundation. The latter were never found in a structural situation and were thought to be a late intrusion. However, in the case of the Wall is house, these bricks were unquestionably used to shore up or reinforce an older foundation, perhaps as a result of the 1915 storm.

It is evident from the location of the piers and from the photograph that the house was built on Lot 12, and barns and outbuildings on Lot 11 . Probably the barn on Lot 11 is the one built by the Shearers at the turn of the century. There is no surface evidence of a structure on Lot 12 before the Wallis home was moved there ca. 1913. 


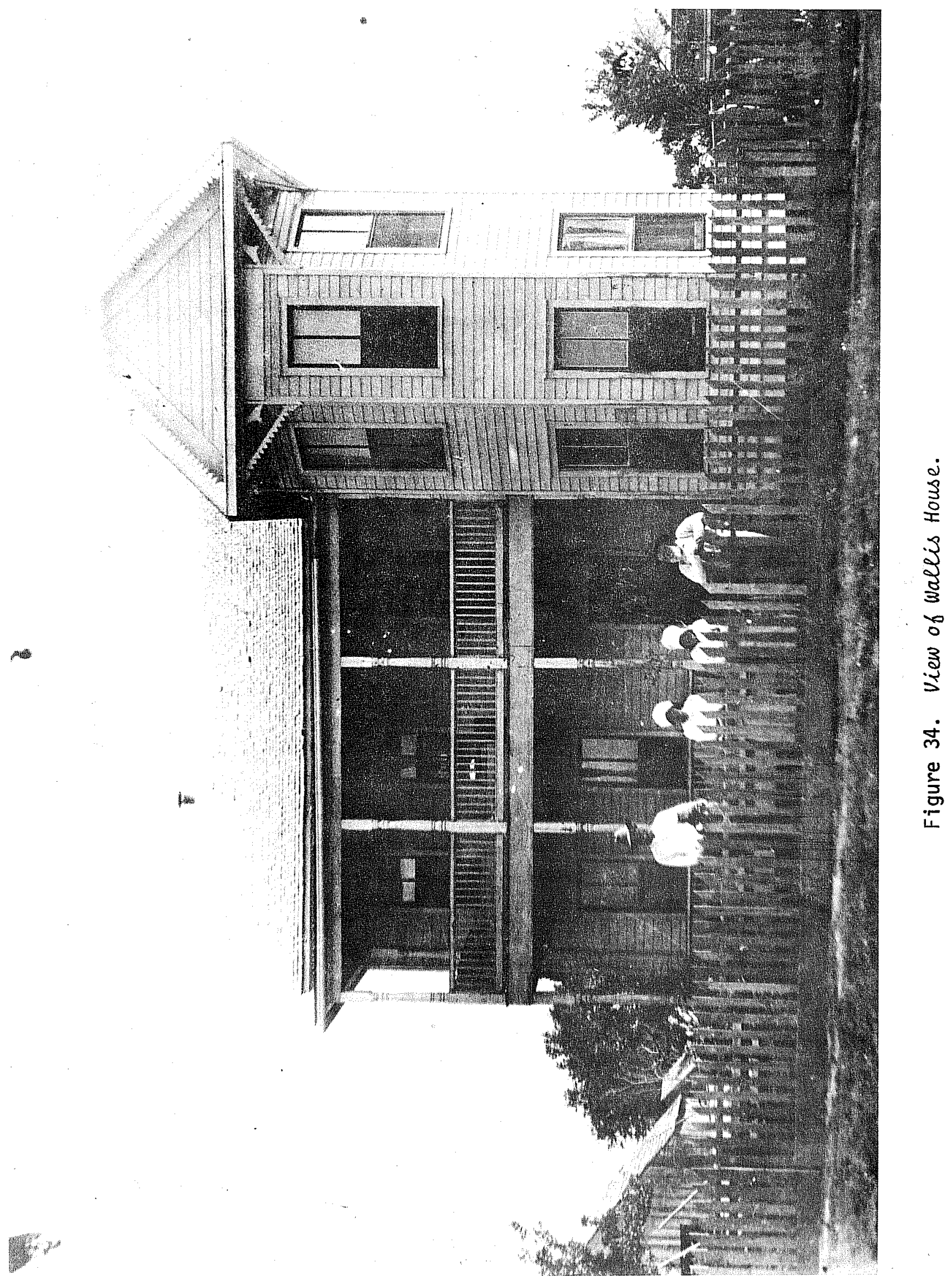




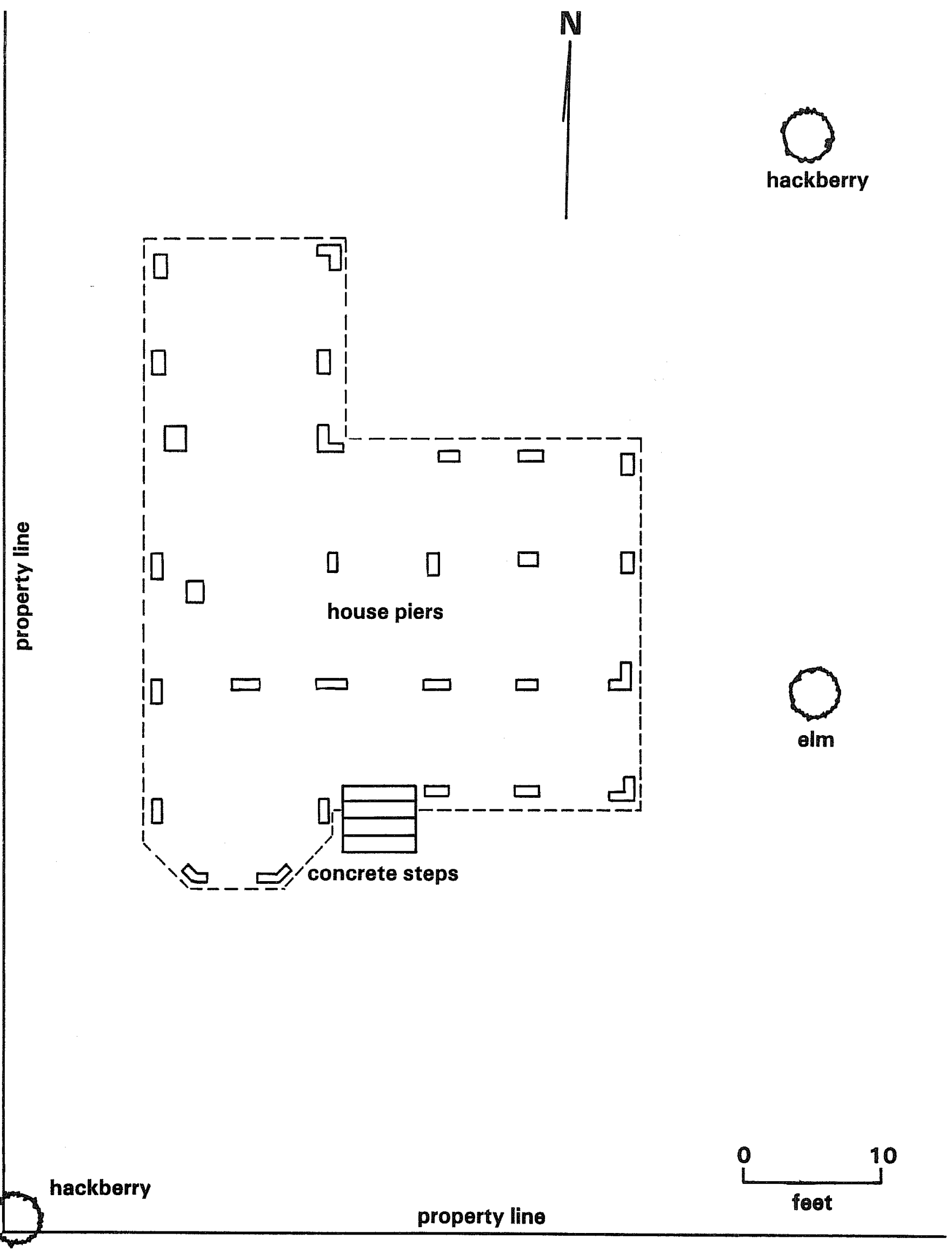

Figure 35. Map of Wallis House Site. 
Wilson Boarding House, $41 \mathrm{CH} 239$

History

In 1882 Lizzie Wilson bought Lots 7 and 8 in Block 10 and built a two-story structure which faced onto both Davis and Main Streets. A two-story porch ran across both facades (Figs. 36 and 37 ). The U.S. Post office operated out of a room on the first floor for a number of years, and the rest of the building was a boarding house run by Mrs. Wilson. In 1898, she ran the following advertisement (wallisville Age 1898):

Wilson House, Wallisville, Texas

Terms $\$ 1.00$ day $\quad$ Special rates to regular boarders

Accommodations First Class

The 1915 hurricane swept away the first floor of the boarding house. Evidently the second story somehow survived, as this remaining section was repaired and continued in use. The structure was finally torn down about 1965.

\section{Archaeological Investigations}

Lots 7 and 8 are completely overgrown with trees and underbrush. A thorough surface survey failed to find any above-ground structural evidence remaining. However, an area to the north end of Lot 8 showed evidence of a trash disposal area in an animal burrow's backdirt. A $1-\mathrm{m}^{2}$ test pit was laid out to one side of this disturbance in order to obtain a sample of the artifacts and to determine the depth of the deposit. This test was located 100 feet north from the center of Main Street and 98 feet west from the center of Davis Street. It was excavated in 10- cm levels until the deposit ceased at $30 \mathrm{~cm}(1 / 4$ of the 20 to $30 \mathrm{~cm}$ level was completed). Upon analys is it was noted that there was no appreciable time distinction between artifacts from the top and bottom levels, and cross-mending of the ceramics confirmed this. Therefore the complete deposit wi11 be treated as one unit for purposes of this report.

The test pit contained an interesting and varied assortment of artifacts typical of the time of Mrs. Wilson's occupation, from 1882 until about the time of the 1915 storm (see Appendix II for a detailed catalog). Evidently this particular area was not used for dumping after 1915, since few of the artifacts date past that time. Personal articles included numerous tiny objects, such as hooks, buttons, and snaps for fastening clothing, smal1 brass buckles and hinges, shoe lace eyes, and part of a fancy cuff link. The presence of children is indicated by parts of several porcelain dol1 heads and bodies and a broken doll's tea set, as well as clay marbles and parts of a slate and slate pencil. Building material consisted of brick and window glass fragments and over 500 nails and spikes. The nails were about evenly divided between cut and wire nails, indicative of this time period when cut nails were being gradually superseded by wire nails (Nelson 1968). Although lamp chimney fragments are present, there are also pieces of the earliest electrical equipment, indicating a change taking place there. The 


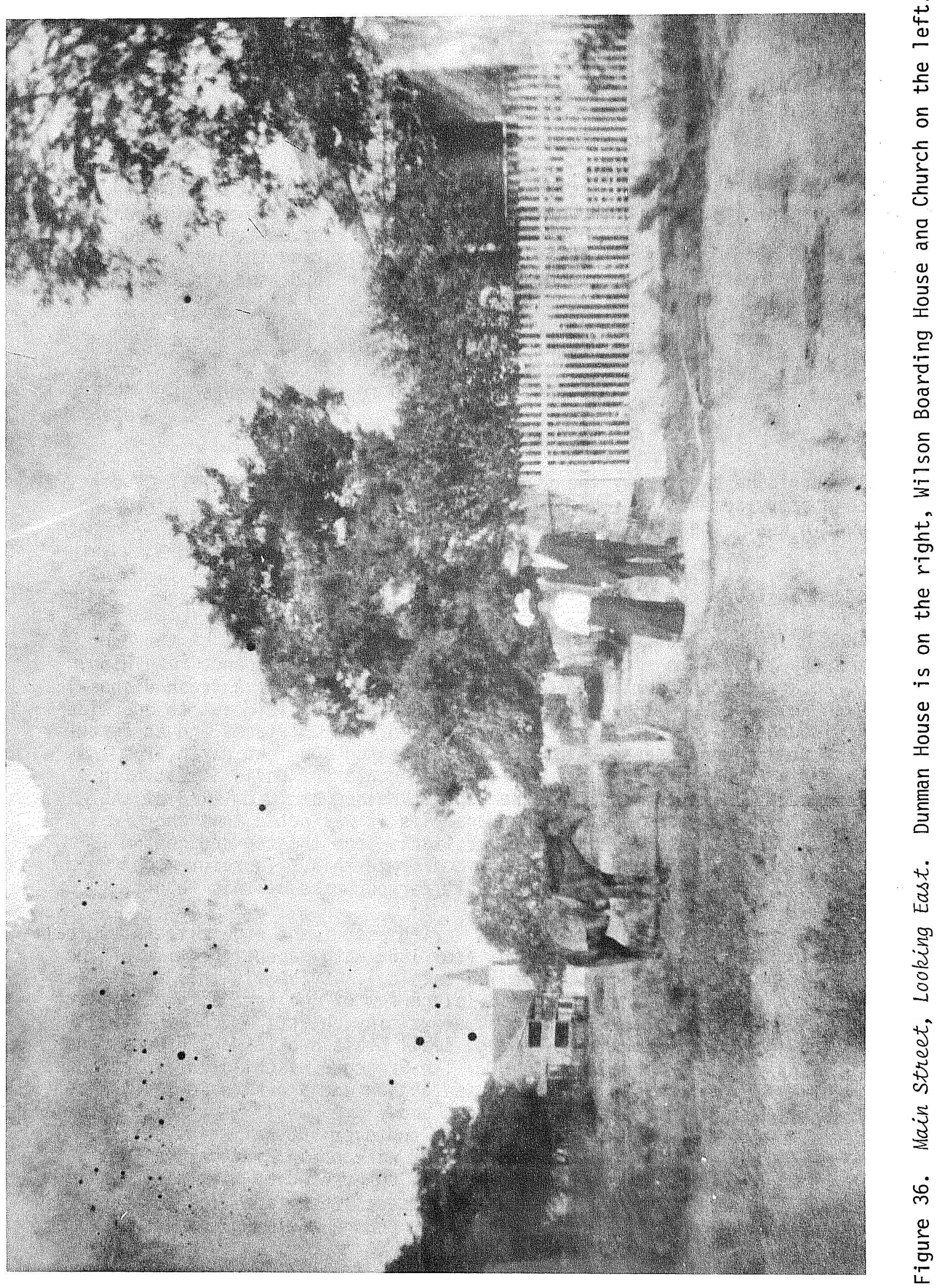




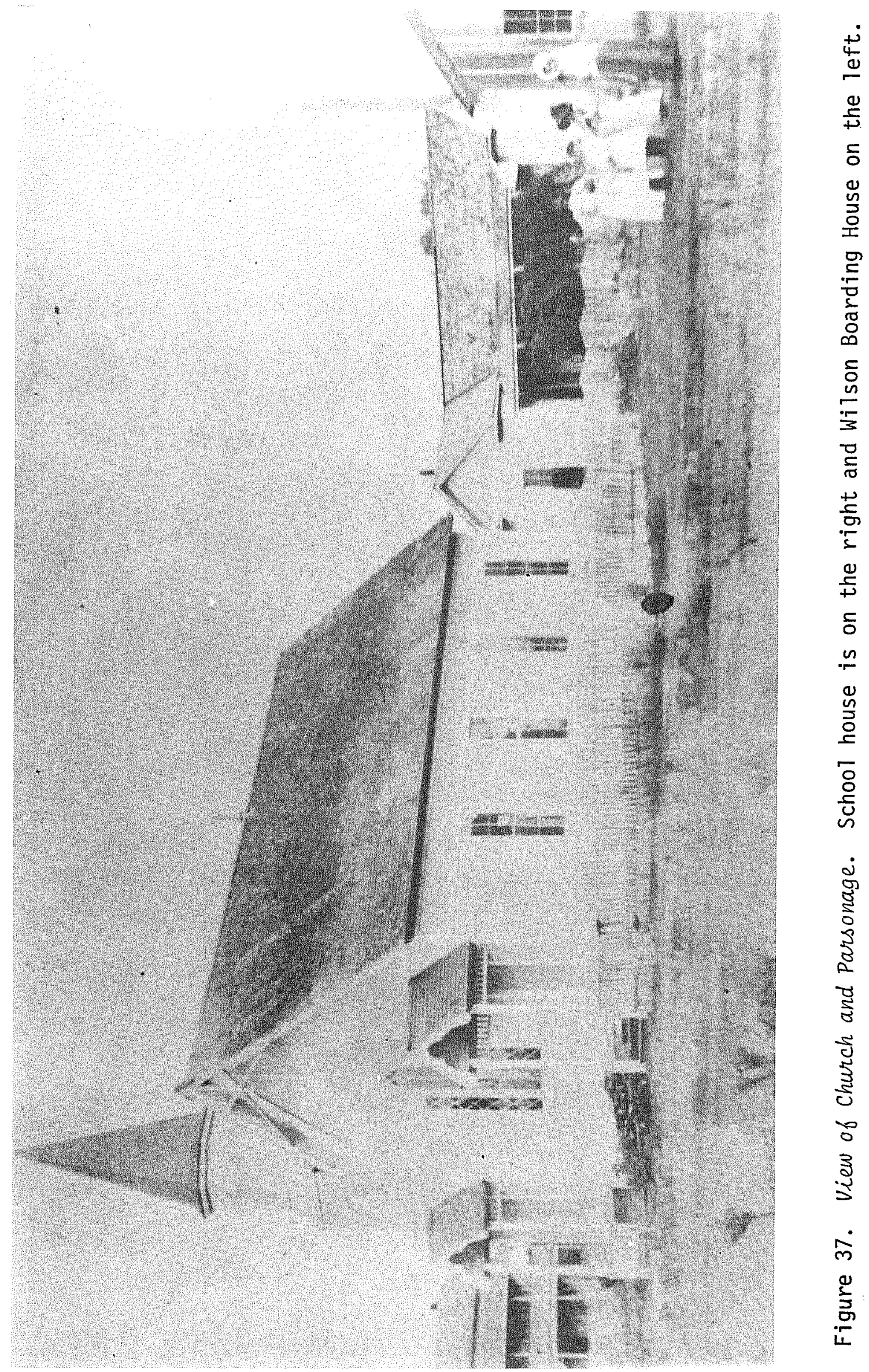


ceramics were predominantly the plain white ironstone china which was fashionable in the late 19th century, with a small proportion of decalcomania-decorated wares which were increasing in popularity around the turn of the century. The maker's marks present indicate that at least a portion of the ironstone was imported from England. This is not surprising since foreign imports were pouring into the port of Galveston during this time period (Hayes 1974:763). Selected artifacts recovered are illustrated in Figs. 38 and 39.

Glass containers were well represented in the sample, which included medicine bottles, food containers, and canning jars. Both hand-finished and machinefinished necks are present (Fig. 40).

\section{Vertebrate Remains (Table 14)}

A total of 420 bones was recovered from a $1-\mathrm{m}^{2}$ test pit at this late 19 th century boarding house site (41 CH 239). Almost half (48\%) of that amount had been burned, and many had been cut with a saw blade of some sort. Twenty-one percent of the recovered osteological material was identified at least to vertebrate class, and every vertebrate class except Amphibia was represented.

Small mammals in this sample are represented by jackrabbit (mandible fragment) and fox squirrel (a burned humerus). Some zoogeographers place Chambers County beyond the current range of jackrabbit, but 01 sen (1964) and Burt (1952) show the county within the easternmost range. Fox squirrel is indigenous to the area as well.

Pigs and cattle are expected domesticates in a historic site. At least two pigs are indicated by both mature and immature bones. None of the identifiable pig elements had been burned, and they all come from leve1 1. Bos taurus, on the other hand, is suggested by only large rib fragments with saw marks and two vertebral epiphyseal fragments. These elements are very fragmentary and are among the least useful as diagnostic elements; therefore, the archaeologist may want to add these five elements to the large mammal category. Nineteen of 23 elements in this last category have saw cuts on them and are so nondescript that the body parts are indeterminable. Eleven of the 23 have been burned.

The presence of deer is indicated by one burned right ulna fragment and an unburned second phalanx from levels 1 and 3 , respectively. No butchering marks are visible on either element.

Twenty-two percent of the identifiable material are birds. A very small burned cranial element and six long bone fragments are too broken to determine species, but the remaining bird bones can be identified as belonging to two sub-families of waterfow1: Anatinae, or surface-feeding ducks, and Anserinae, geese.

At least three individuals of the Anatinae type are indicated. Two right scapulae compare well with the medium-sized mottled duck (Anas fulvigula), which is a year-round resident along the Texas coast (Peterson 1960). A third scapula is smaller than those from the mottled duck and compares well with the teals, either green-winged ( $A$. carolinensis), biue-winged ( $A$. discors), or cinnamon (A. cyanoptera), all of which spend winter along the coast (Peterson 1960). 
Figure 38. Personal Objects from Wieson Boarding House.*

a. she11 button

b. bone button

c. cuff link, opaque pink glass set

d. hand-cut celluloid object, possible guitar pick

e. bisque doll head, probably French, 1880-1890 (Fox 1973:Plate 68)

f. White bisque doll head, painted hair and eyes, probably German, post-Civil War times (St. George 1948:39-40)

g. fired clay marble

h. fired clay marble

i. early electric light bulb base

j. clock gear

k. clothing fasteners

1. clothing fasteners

m. tab from clothing fastener, "TRUEFIT"

n. early electric plug

o. small hinge from jewelry box or similar object

p. elaborate brass buckle, once had glass sets

q. pocket book frame

* A11 specimens shown actual size 


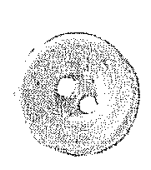

a
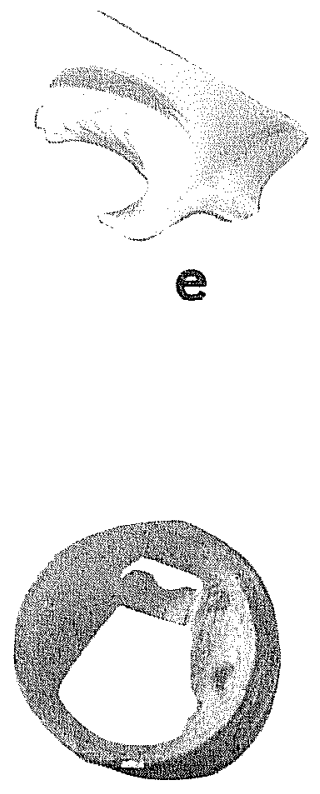

i

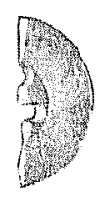

b

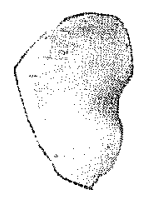

$f$

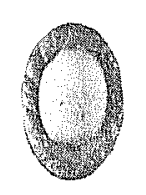

c

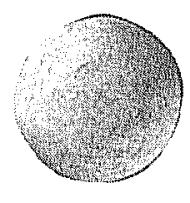

g
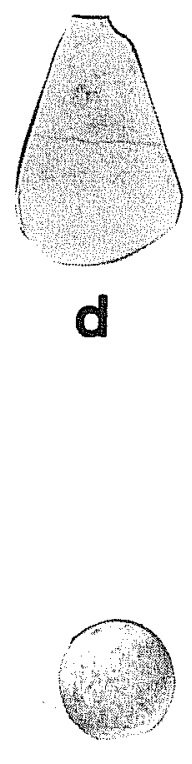

h

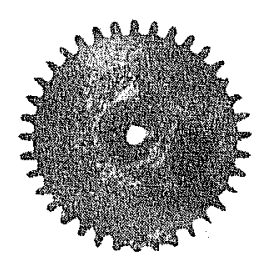

j
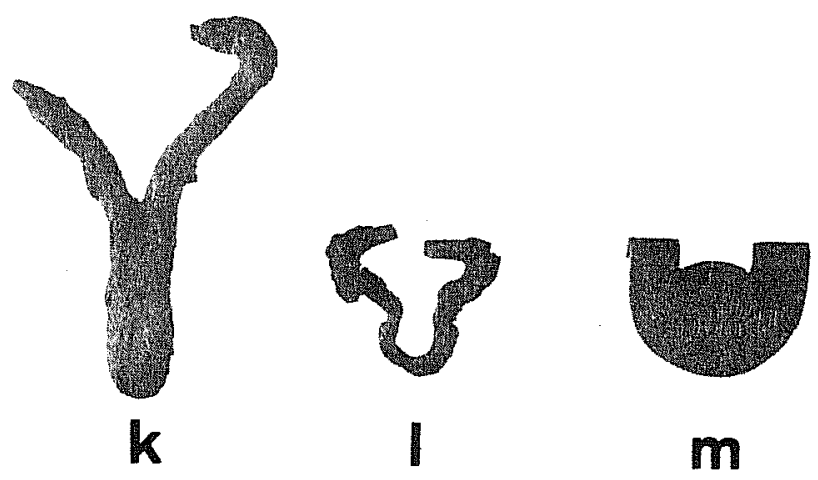

m
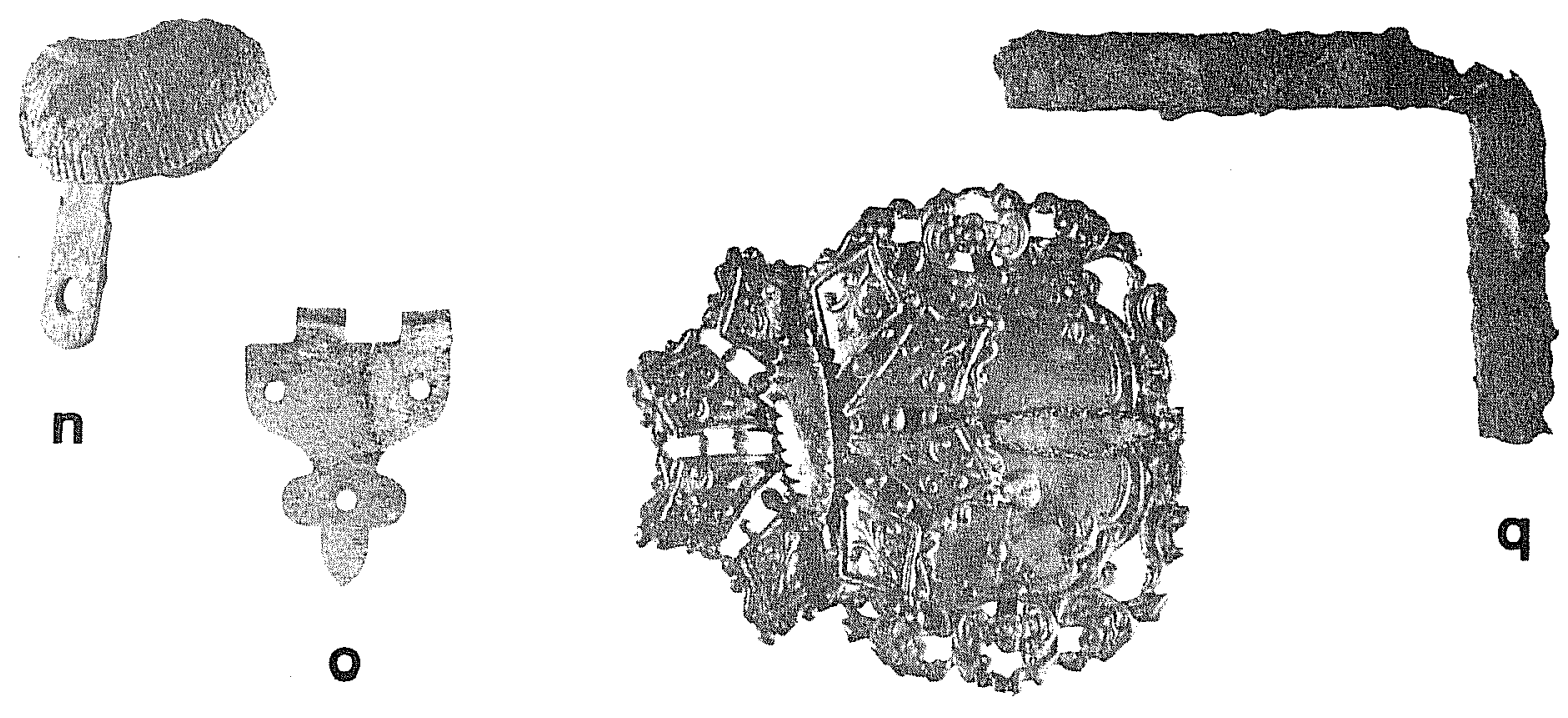

p 
Figure 39. Ceramics from Wilson Boarding House.*

a. blue shell-edged pearlware plate, before Civil War

b. red, brown and green decal-decorated oriental porcelain with golded rim, saucer

c. red overglaze-decorated Japanese porcelain cup, turn of the century (Ray 1974:150)

d. gold printed design on white earthenware plate

e. yellow, green and pink decal-decorated porcelain cup

f. red decal on iridescent glaze over repoussé design on porcelain cup

g. "ROYAL IRONSTONE CHINA/JOHNSON BROS./ ENGLAND" plate, ca. 1883-1913 (Godden 1964:355)

h. "IRONSTONE CHINA/J \& G MEAKIN/HANLEY/ ENGLAND" plate, ca. 1890 and after (ibid.:427)

i. pink, blue and green decal on porcelain cup

* A11 specimens shown actual size 


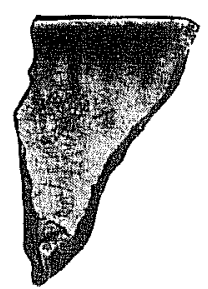

a
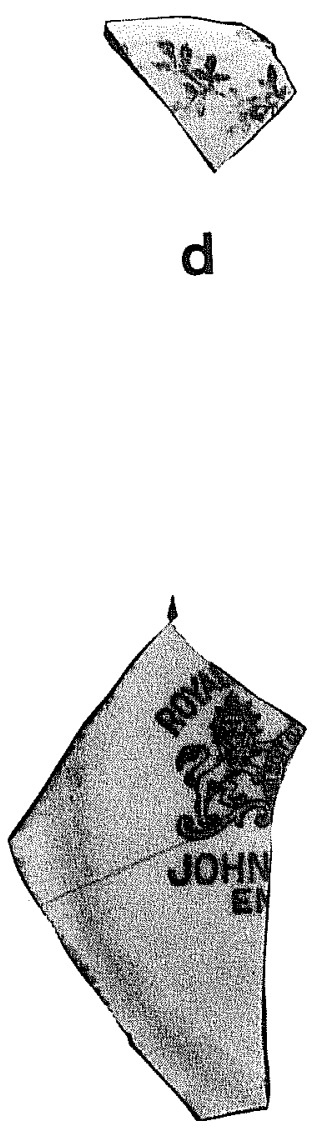

g

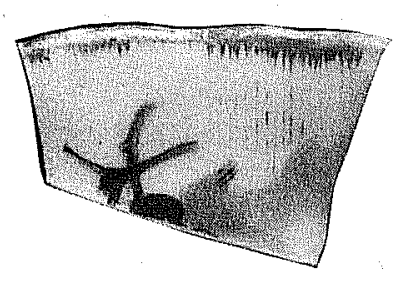

b
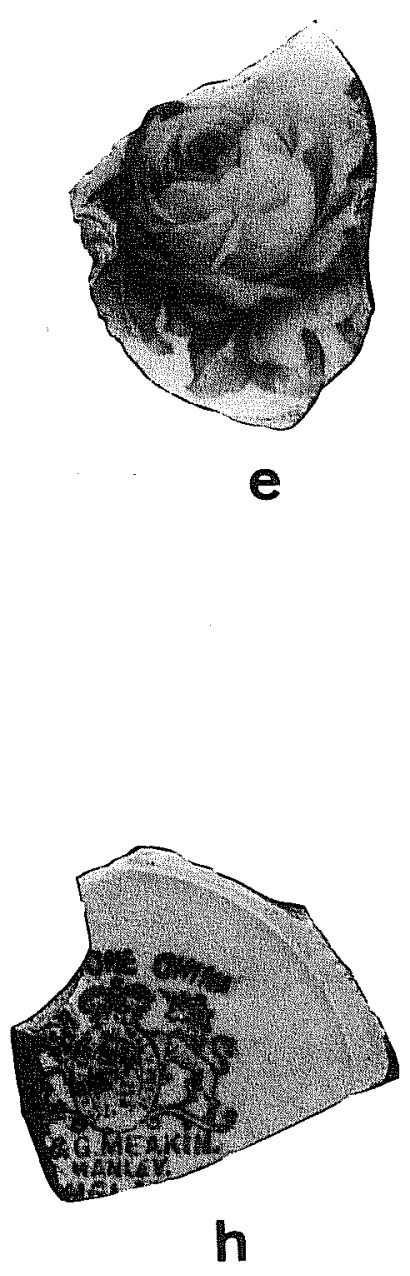

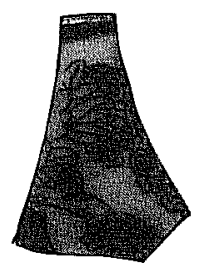

C

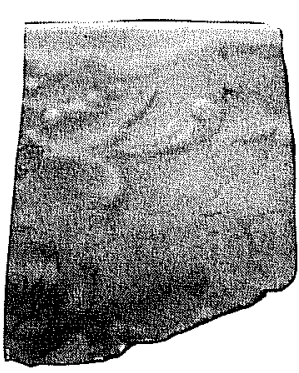

f

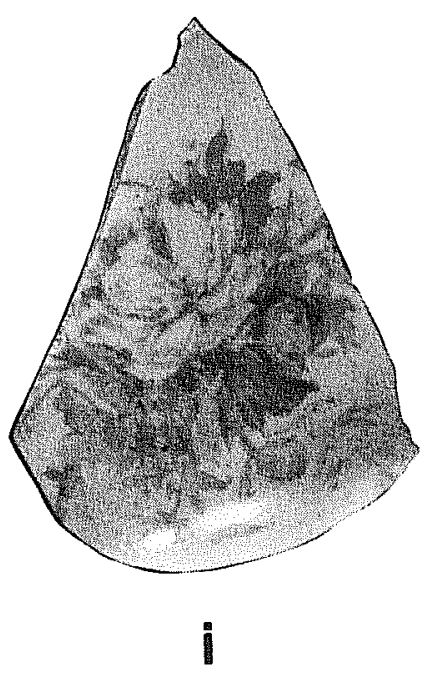


Figure 40. Glass from Wilson Boarding House.*

a. pressed glass container, post-1845 (Lorrain 1968:39)

b. pressed glass container, post-1845 (ibid.)

c. pressed glass container, post-1845, Peacock Feather design (Lorrain 1968:

Figure 3b)

d. glass stopper

e. Tight purple neck of food jar, hand-tooled $7 \mathrm{ip}, \mathrm{ca} .1880$ (Kendrick 1967:22)

f. aqua medicine bottle, "DR. S. PITCHER'S/ CASTORIA," hand-tooled $1 \mathrm{ip}$

g. clear flavoring or medicine bottle, hand-tooled 7 ip

h. "CHEESEBROUGH MFG. CO./VASELINE," machine-made lip, after 1903 (ibid.:43)

* A11 specimens shown actual size 

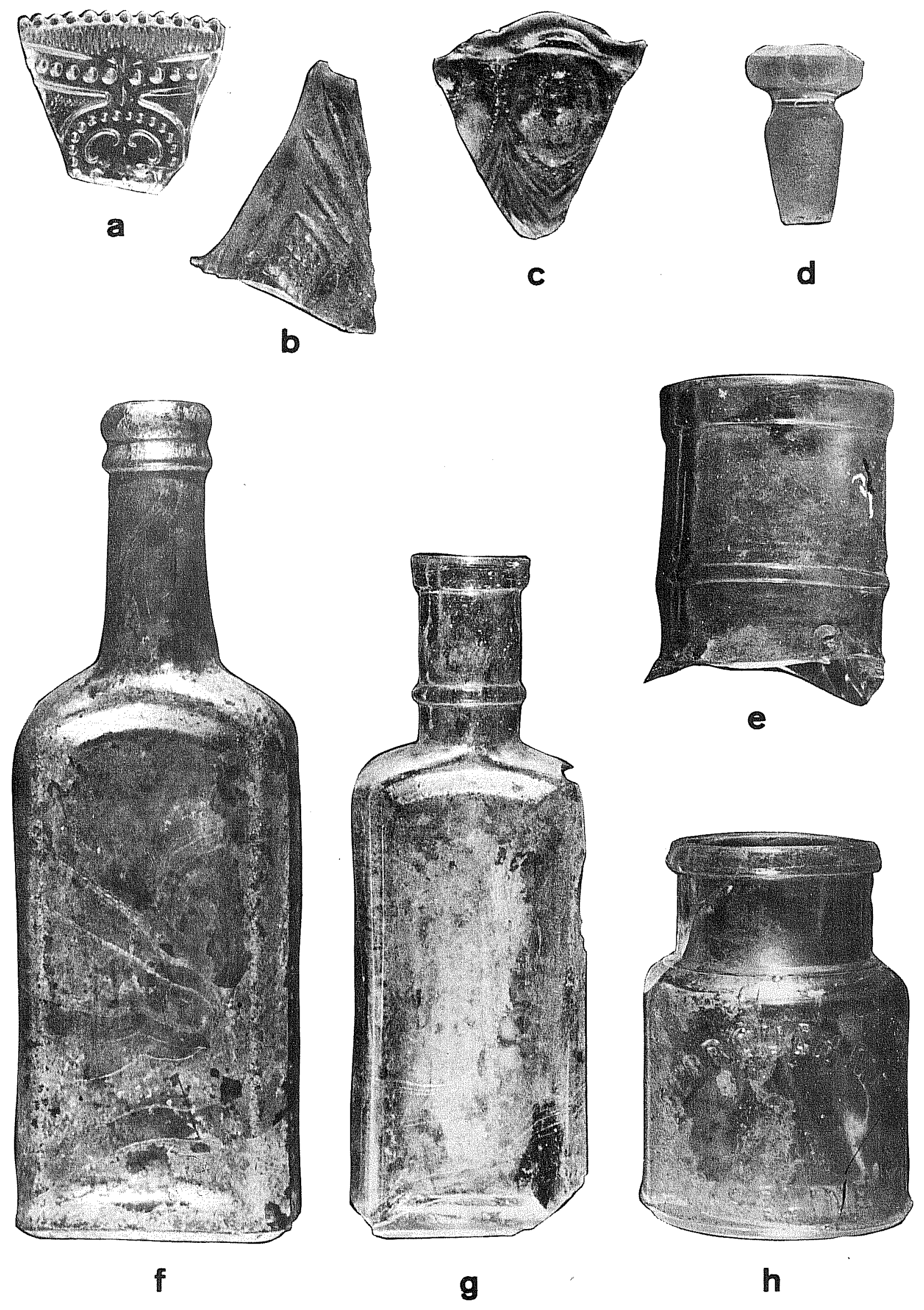


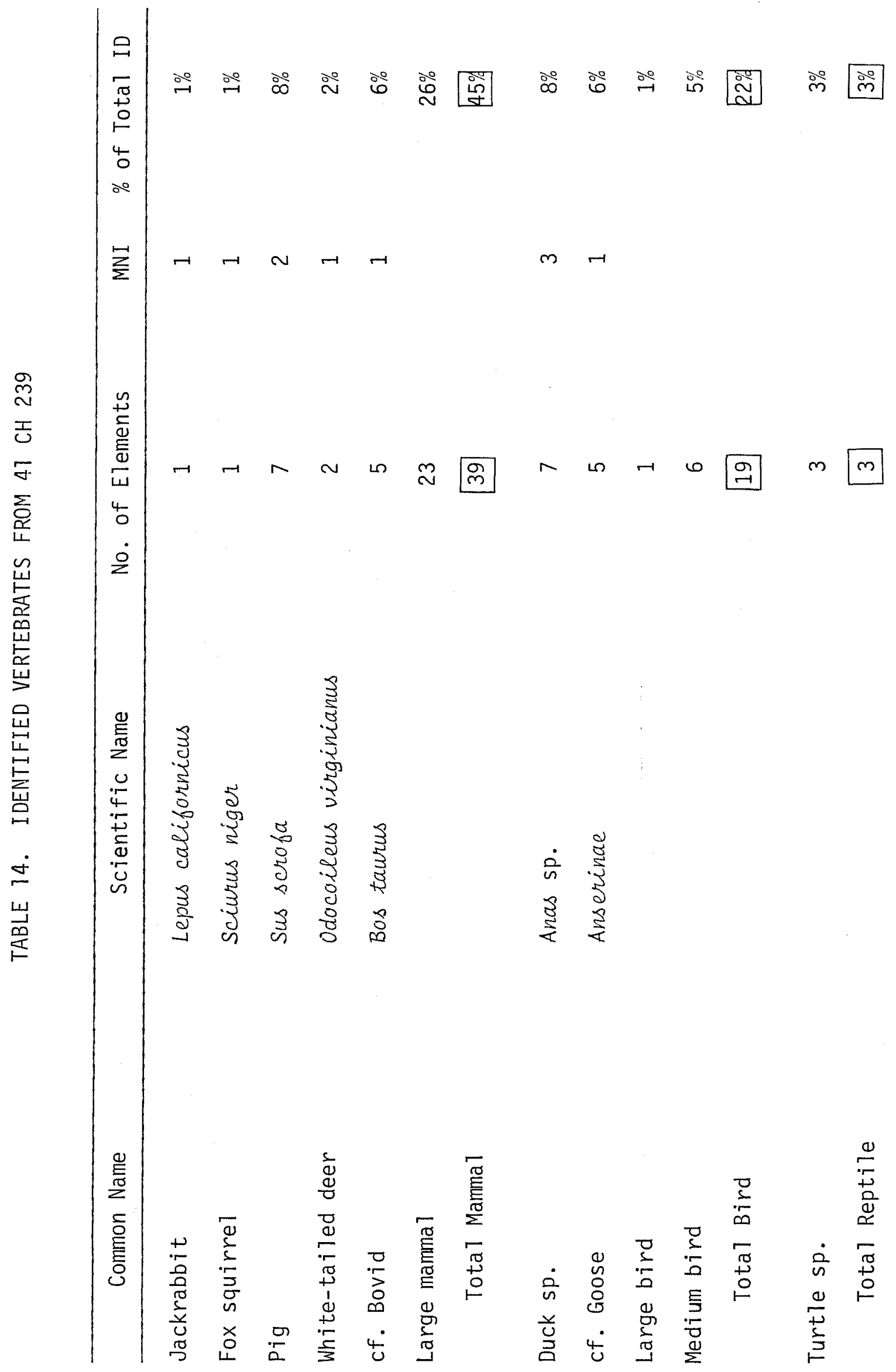




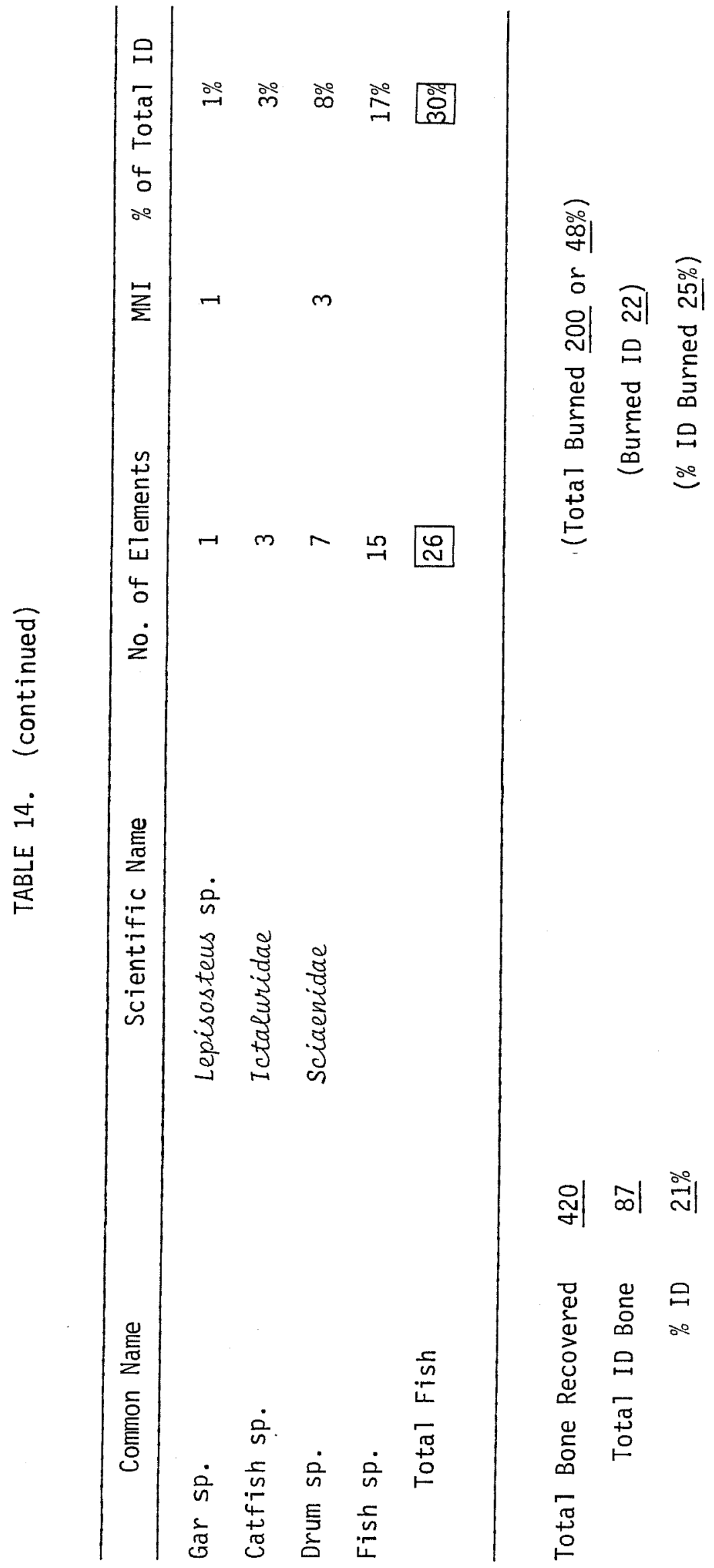


The five geese elements are too small for Canada goose; therefore, the smaller brant geese could be considered appropriate, especially the snow goose (Chen hyperborea) or b7ue goose (Chen caerulescens). Both are known to winter in marshes, ponds, bays, and coastal prairies of southeast Texas (Peterson 1960).

Only three fragments of turtle she11 were recovered, and a 11 were found in leve1 1. One fragment is burned, but the other two are bleached, suggesting some amount of surface exposure. One of the weathered she 11 fragments is quite large $(5.5 \mathrm{~mm}$ thick, $35 \mathrm{~mm}$ 1ong), but it has no diagnostic characteristics.

Fish were recovered from each level and constitute 30\% of the identifiable bone. Only one broken gar scale was recovered. Catfish elements were limited to level 1 , and the large dorsal spine fragment indicates at least one large individual from either the blue catfish or flathead catfish. Size cannot be determined from the remaining two catfish cranial elements. Three individual drum are indicated from three otoliths of different sizes, all from level 1 . The remaining unspecific fish elements are vertebrae or spines from medium-sized individuals.

\section{observations and Conclusions}

If this one test pit is any indication, there is a great deal of artifactual material in the ground in the vicinity of Mrs. Wilson's establishment. It is interesting to compare the material from this site with the contents of a cistern recently excavated by the Center for Archaeological Research in a residential neighborhood of downtown San Antonio (Katz 1978:41-72). The cistern was filled with trash between about 1899 and 1905 (ibid.:47). The similarities between the collections are rather surprising, considering the distance between the two sites and their differences in setting and background:

Similar

ceramic types

glass containers

pressed glass

lamp chimneys

buttons and cuff links

hooks and snaps

dolls and dishes

slates and marbles

cut and wire nails

brick
Absent From Wilson

horse equipment

horseshoes

celluloid collars and collar buttons

Mexican ceramics

embossed local drugstore bottles

It appears that the selection of objects in use in Texas households around the turn of the century differed very little from one town to the next, probably due to the fact that everything was being brought into the state through the same ports using the same suppliers. Aside from slight differences in styles of dressing or personal tastes, there is little indication in a collection of where it originated. Mrs. Wilson obviously did not keep a horse on her town lot, and would perhaps have hired "a rig" to make any necessary trips, or may have had land on the edge of town for stabling a horse. The similarity of the 
artifacts at a commercial establishment to that of a residence can in this case be explained by the fact that the Wilson family not only lived on the site but probably fed their clients family-style meals as well. Embossed druggists' bottles and celluloid collars were probably products of city life not considered necessary in Wallisville, and the absence of Mexican pottery is understandable.

The possibilities for detailed comparative studies using the deposits in the Wilson backyard provide an idea of the sort of information which can be obtained from the town as a whole.

\section{Block 11}

\section{History}

The only part of Block 11 which has not been removed for construction of the levee is Lots 11 and 12 . The school house was built in 1860 on Lot 11 . It was originally a board and batten structure; it was remodeled in 1913, and new siding was applied. When the church next door was destroyed by a storm in 1923, it was used as a church as we11. It was also the office of the newspaper, the wallisville Age, and for a time in the 1920s was used as a post office (John Middleton, personal communication). When the school building was removed from the lot, it was sold to the Oak Island Baptist Church and was used there until 1979, when it was moved back to Wallisville. John Middleton has purchased and refurbished the building for use as an historical information center and meeting hall.

Lot 12 was deeded to the Methodist Church in 1885, and a wooden church was built in 1895 (Liberty Vindicator 1895, September 20). A parsonage was built directly behind the church (Fig. 37). A storm demolished the church in 1923, and the lot remained vacant after that time.

\section{Archaeological Investigation}

The remaining area was surveyed briefly to determine if remains of the foundations of the school and church could still be seen. Due to modern trash-dumping in the area, the lot would have to be cleared in order to be sure of the location of the school building. No surface indications remain of the foundations of the church building.

\section{observations and Conclusions}

Lot 12 showed no sign of the existence of the church. However, it appears not to have been disturbed since the church was removed, and archaeological investigation could probably establish its layout and that of surrounding pathways and structures. The lot on which the school was built still has the concrete sidewalk up to where the door was located, and the exact location of the building could probably be determined. 


\section{Block 15}

\section{History}

Lot 1 was the site of the Ed Dunman home (Fig. 36), probabiy built about the turn of the century. Several small homes faced Main Street on the north side of Block 15. On Lots 7 and 8 was a roller-skating rink built in 1906, a popular place with the young people of the area. There was a player piano in the center surrounded by a dance floor, with the skating area around the outside. Also in the same block were a barber shop and a cobbler's shop. This entire block was destroyed in the 1915 storm (John Middleton, personal communication).

\section{Archaeological Investigation and Observations}

The southern half of the block was found to be too densely overgrown to survey. The northern half was examined wherever it was possible to beat a way into the clearer spots and examine the ground. No early structural remains were found. On Lot 1 indications of recent disturbance were found, along with recent trash and evidence of a plumbing system, probably the remains of a recent establishment.

\section{Block 16}

\section{History}

This block was utilized primarily by the Wallisville Mercantile Company (owned by $C$. R. Cummings), which was the commissary for Cummings' lumber mill across the river. The store was run by Beauregard La Four, who lived in a house north of the store. The commissary had a wharf on the river where mail and freight boats would unload (Nina La Four Mayes, personal communication). There was a row of small houses north of the commissary (L. B. La Four, personal communication).

\section{Archaeological Investigation and Observations}

This entire area is densely overgrown with ground cover, and it was impossible to survey. Enough photographs of this area still exist to allow a tentative reconstruction of the commissary on paper, but there is no way of knowing at present if any evidence remains in the ground.

Conclusions on Wallisville

In assessing the historical, archaeological, and anthropological potentials of a site which encompasses an entire town, many questions should be considered. Perhaps the most important of these concern the significance and the integrity of the site. Was the town truly typical of its day and time and could it, therefore, give a true picture of a given period? How badly disturbed are the deposits 
from the time period of most interest? Indeed, is there any evidence remaining which has not been swept away by flooding or by later looting or cleaning-up operations? What sorts of information would be gained from studying the town?

Despite the fact that a large section of the town has been removed, it appears that a great deal of information remains in the ground about the history of Wallisville and of the individuals who lived there. The period in which this particular town was at its peak of importance (ca. 1890 to 1906) is one which has had relatively little attention from Texas historians, most of whom have concentrated on the more exciting days of the revolution and the founding of the state. It appears from studying the history of the area that this town grew in a logical way in response to a particular need and special regional pressures. Among these were the need for lumber to build the rapidly growing towns of Galveston and Houston and the need for a market town and county seat for a developing region. The majority of the transportation was by water, and the entire focus of the area was upon the Trinity River valley. The economy of Wallisville, therefore, was based upon the lumber and ship-building industries, as well as upon agriculture and stock-raising and the distribution of their products to towns on the coast.

Since there was a major disaster which effectively stopped the growth and development of the town, there is a conveniently limited time period within which to work. The later residents of the town site tended to continue to use the older structures rather than building new ones. There is remarkably little concrete in town, for instance, and no major disturbance of sites by later types of construction.

The portion of Wallisville that remains apparently contains sites representative of all the various activities which were carried out in town, including mi11s, stores, hotels, and government buildings. There is, as we11, a full gamut of residential types, from the shanties of the mill workers to the finer Victorian residences of the social leaders of the community. Comparative studies should thus be possible of the habits, personal tastes, and life styles of the residents, as reflected in their personal belongings and living arrangements. Critical problems such as the effects of the importation of large groups of mill workers into a smal1, rural community might also be studied.

The sources of information which could be used are many and varied, thanks in large part to the devoted work of local researchers who have compiled tremendous amounts of vital information, such as old newspapers, diaries, personal interviews, and photographs. The support of the local community for historical research is unusually enthusiastic, stemming in part from the fact that a large part of the population are direct descendants of the earliest residents of Wallisville.

What could archaeology contribute to future historical research and possible restoration of the town? Archaeology can, as demonstrated above, take eyewitness accounts and old photographs and literally pin them to the ground, by determining exact locations, sizes, and methods of construction of buildings, landscaping patterns, and locations of unremembered outbuildings. Detailed information can also be recovered on the living habits of the people who used these buildings, their tastes, and their personal belongings. While such details may not seem of 
earthshaking importance to the world at large, they are an important facet of restoration, as anyone who has visited Williamsburg, Jamestown, or other restorations can readily understand.

Why should this type of research be important--of what use to our current world? Folklorist Henry Glassie (1975:29) has remarked that from history we learn about the rich and famous, about the pioneer settlers, and perhaps even about the poorest classes, which have been studied by reason of their quaintness. "Our greatest lack... lies in the era spanned by the second to fourth generations in any occupance, and among the people of the working class." In studying the growth and change in a small, rural town at the beginning of the 20th century, we can obtain needed insight into the social and cultural changes taking place in the world today.

Recommendations

The town site of Wallisville should be protected from further destruction both by man and by the elements. Until the recent installation of gates and fences by the Corps of Engineers, the area was being destroyed and vandalized by the public. We urge that the site be placed on the National Register of Historic Places as a Historic District, or if possible added to the Orcoquisac Historic District which is located directly across IH 10 to the north.

Plans are currently being studied for creating a historical restoration on the town site. The low elevation of the town ( 5 to 10 feet above ms 1 ) means that the area will be subject to seasonal flooding on a regular basis when the reservoir is constructed. It appears that there are several possible solutions to this problem: (1) to construct a low dike along the river bank on the town site; (2) to plan any subsequent development within the town so as to endure the flooding with a minimum of disturbance; or (3) to eliminate the flooding of the town site by creating a flood water bypass channel for the river. A similar relocation of the river has recently been suggested (Fullen 1979) in order to avoid cutting a channel through the Wallisville site as proposed by the Fort Worth District of the Corps of Engineers in plans for future river navigation improvements (Corps of Engineers 1979b). Dike construction would require intensive archaeological mitigation in the areas to be disturbed. In any case, the proposed reconstruction of the courthouse as a historical center should take into consideration in its design the probability of occasional flooding of the area. We recommend that an engineering study be carried out at the town site to evolve the most environmentally sound solution to this problem. We also urge that the borrow pits within the town be refilled, and that the affected area be restored as much as possible to its original elevation, no matter what the future of the site.

Future Work

The courthouse and jail site $(41 \mathrm{CH} 228)$ should have further investigation before any restoration is considered or plans drawn. The exact building foundation outlines and details should be carefully uncovered and drawn and the associated pathways mapped in relation to the buildings. Because of the fragility of the 
architectural features and the past history of vandalism, this should be done in direct connection with the work of the architect, and the remains should be quickly covered or protected in some manner.

The W. B. Gordon house site ( $41 \mathrm{CH} 241$ ) has probably been too thoroughly disturbed by later construction to yield much archaeological information. The site should be marked and protected.

The T. J. Shelton house site ( $41 \mathrm{CH} 237$ ) would be an excellent study for an archaeological field class. The house foundations, paths, fences, etc., could be located and mapped. The sites of the related barn and outbuildings which appear in photographs could also be located and examined. It would be of architectural interest, also, to follow the house to its new location and document its entire life story.

Block 9 contains at least two structures of importance to the town's history, the La Four/Davis Hotel and the Davis Store. It appears that later concrete slabs have not encroached on the original building locations. Archaeological testing should be done to determine how much evidence remains of both establishments. This would entail extensive brush clearing and should be done when the foliage has died back in the winter. Eyewitness accounts of both hotel and store should be recorded for future reference. If sufficient remains still exist in the ground, archaeological excavations should be undertaken in order to reveal the character and locations of the buildings, to recover evidence of the articles sold in the store, and to determine the sorts of individuals who inhabited the hotel. Information about these subjects is also available from local newspapers of the time.

The Dr. T. W. Shearer house site (41 CH 238) lends itself particularly well to a number of archaeological investigations. The early gin site on Lot 1 should be found and excavated. The small cottage which was standing in 1889 and its subsequent additions and improvements would make another important study. The doctor's office and its immediate surroundings should be investigated, as should the other structures mentioned by Mrs. Shearer in her descriptions. The landscaping plan could be restored using those same descriptions plus archaeological techniques.

The H. R. Wallis house site (41 $\mathrm{CH} 240$ ) would be an interesting project to research, since the photographs and written descriptions are quite clear and detailed. It should be possible to reconstruct the outlines of the Shearer barn, which later became the Wallis barn, and the we11 and windmi 11 used by the Shearers to water their stock. Here, again, the house could be followed and documented on its new site.

The Wilson Boarding House site (41 $\mathrm{CH} 239$ ) appears to have relatively undisturbed deposits surrounding it. A great deal could be learned about life in the Wilson menage through careful excavation and analysis of artifacts. The back yard should contain traces of a number of outbuildings significant to the history of the site, including latrines, storage sheds, and possibly a wash house.

Block 11 contained two important public buildings which might one day be restored, or at least marked in some significant way. Both the church and 
the school building sites could be located and significant artifacts recovered through archaeological excavations, to aid in their interpretation.

Block 15 contained small shops and homes, as well as the skating rink. Additional testing should be done when ground cover can be removed. Then, extensive excavations should be planned if the area is to be disturbed in connection with diking or other construction. This block is especially important because it is the only remaining group of smaller homes and commercial buildings still available for study.

The Cummings Store on Block 16 was an important part of the economy of the town. Testing should be done in this area, along with extensive brush and ground cover removal, to determine what evidence remains or if the 1915 flood removed everything of interest from the site.

The area to the east of the developed part of the town once contained the shanties and small houses of the mill workers. This area could be completely cleared and investigated as part of a study in comparative lifeways. Other commercial establishments also were located in this area at various times, including a boat yard and lumber mi11.

Ful1-scale archaeological investigations should precede any plans to reconstruct or restore to their original sites any of these buildings. This would assure that restorations are accurate and would provide information to allow interiors to be accurately furnished for public display. These investigations would consist of large, shallow excavation units which would concentrate on finding the locations of doors, windows, chimneys, pathways, and outbuildings. Since most of the structures stood upon piers, careful work will be necessary to delimit the walls and roof 1 ines of structures in order to accurately reconstruct their originat size and orientation.

WEST OF THE TRINITY RIVER

Cummings Lumber Mi17, $41 \mathrm{CH} 243$

\section{History}

C. R. Cummings operated saw mills at Anahuac and Liberty in the 1890s. In 1898 he closed them and concentrated his operation at Wallisville, building a large, new plant on the west side of the river opposite the town (Fig. 41). The name was changed to the C. R. Cummings Export Lumber Mi11 Company (Harry 1940:97). By 1903 Cummings was producing 80,000 board feet of lumber a day. The mi11 had a band saw, a circular saw, a shingle and planing mi11, three dry kilns, and dry sheds. All the clear output from the mill was being shipped to Germany (Texas Almanac 1904:233). The mill was the major business in Wallisville and provided 400 jobs for its inhabitants (John Middleton, personal communication). Boarding houses were constructed for white and Negro workers to the south of the mill, and small workers' houses were built at the west end of the town, separate sections developing for white, Mexican, and Negro workers (John Middleton, personal communication). The mill's offices and commissary were located 


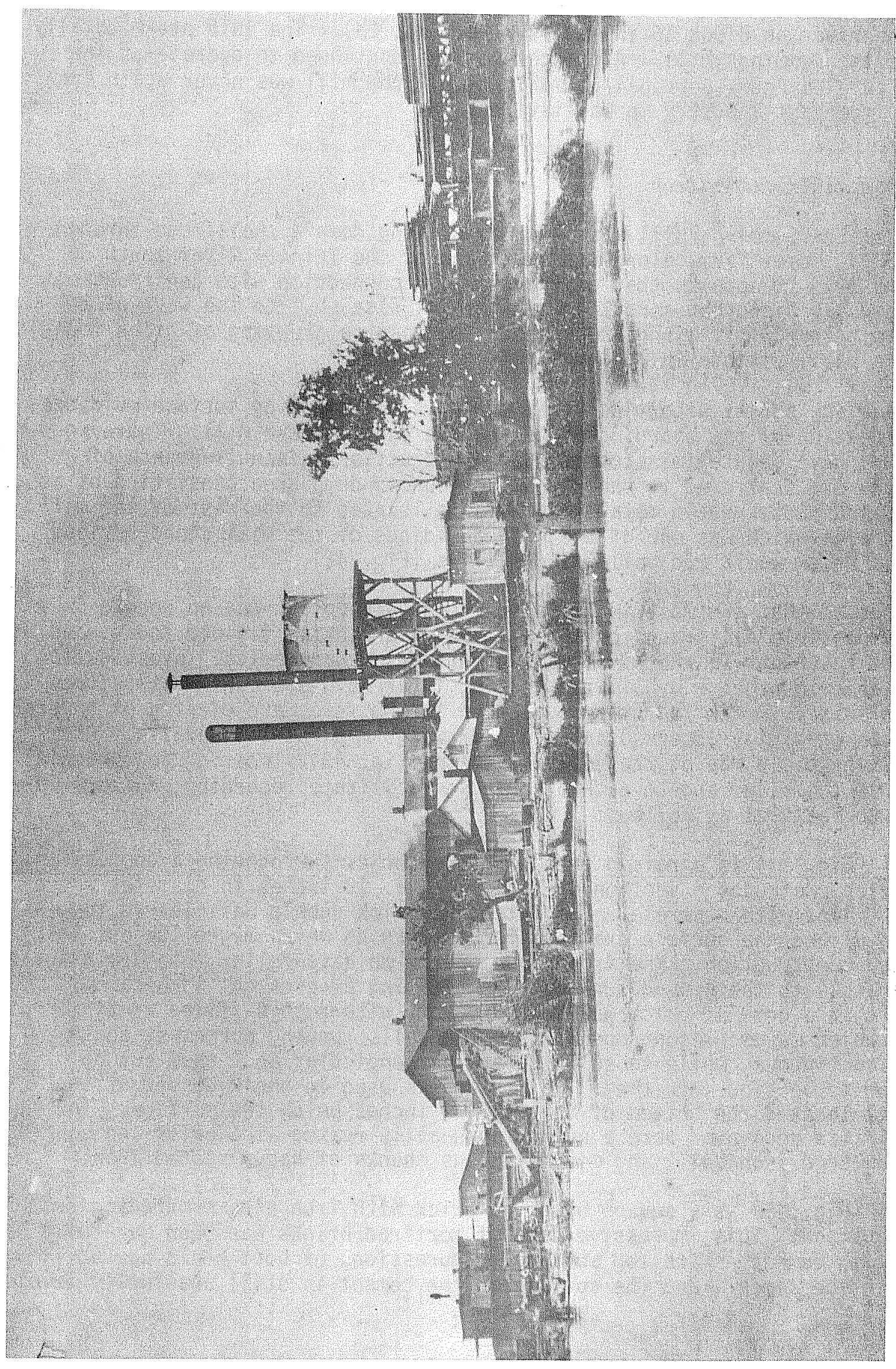

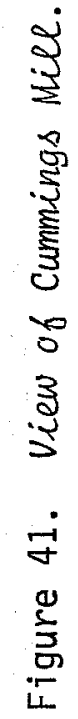


across the river on Block 16 in Wallisville (Fig. 29). The 1915 storm totally destroyed the Cummings Mi11. Although Cummings continued to operate at the site (Octavia La Four, personal communication), the mil1 was never again such a large, important industry in Wallisville.

\section{Archaeological Investigation}

The site of the Cummings Mill was found by driving down a shell road through the old J. J. Mayes farm, along the west bank of the Trinity River south of Interstate 10 . It appears that earth moving in connection with construction of the road has disturbed a portion of the mill site, but to the west of the drainage pit/borrow pit along the edge of the road, a grouping of brick foundations is still visible in a grove of trees.

Careful surface survey determined that there is no remaining surface evidence for the location of the boarding houses to the south of the mill. These foundations may have been eliminated by road construction, since fragments of brick piers are scattered in the ditch. A mounded dump area consisting of ash, charcoal, and badly rusted metal fragments is located to the west of the mi11. Within an area which was one of the main buildings of the mil1 stand various remains of brick walls and boiler foundations (Fig. 42).

It was decided that the most important thing to accomplish was to record in every way possible all traces of the mill which are still visible today, and to attempt to determine what information further archaeological investigation might be able to provide by 1 imited testing in areas where buried structures appear to exist. Brick features exposed on the surface were cleared of underbrush, then carefully observed and scale drawings made of all details. An overali plane table map of the site was drawn (Fig. 43), locating features in relation to the river and to each other. To facilitate recording, numbers were assigned to features as follows:

Feature 1 (Fig. 44) is a raised area of broken brick surrounding a depression, out of which protrudes a section of iron pipe ca. 12 inches in diameter which has been filled with concrete. The extensive brick rubble was cleared to ground level and the surface examined for patterning which might suggest its subsurface construction. The iron pipe appears to have fallen into a pit and is at an angle to the ground surface. As clearing progressed, it became apparent that a grid of brick walls is present, with rubble-filled areas between, which may represent open pits. The walls running northwest-southeast are continuous, while those which are perpendicular abut them but do not appear to be tied into them. No mortar was used in their construction. A test pit located the bottom of the wall 25 inches below the surface. The only artifacts recovered were a number of heavily rusted wire nails and square spikes, a large iron bolt, and miscellaneous chunks of heavy rusted iron.

Feature 2 (Fig. 45) is a square block of brick with iron bars protruding from its top surface. This impressive cube of mortared bricks has been carefully leveled with cement on its top surface. Impressions of boot heels are sti11 visible in the cement, and the surface of the cement is still absolutely level. 


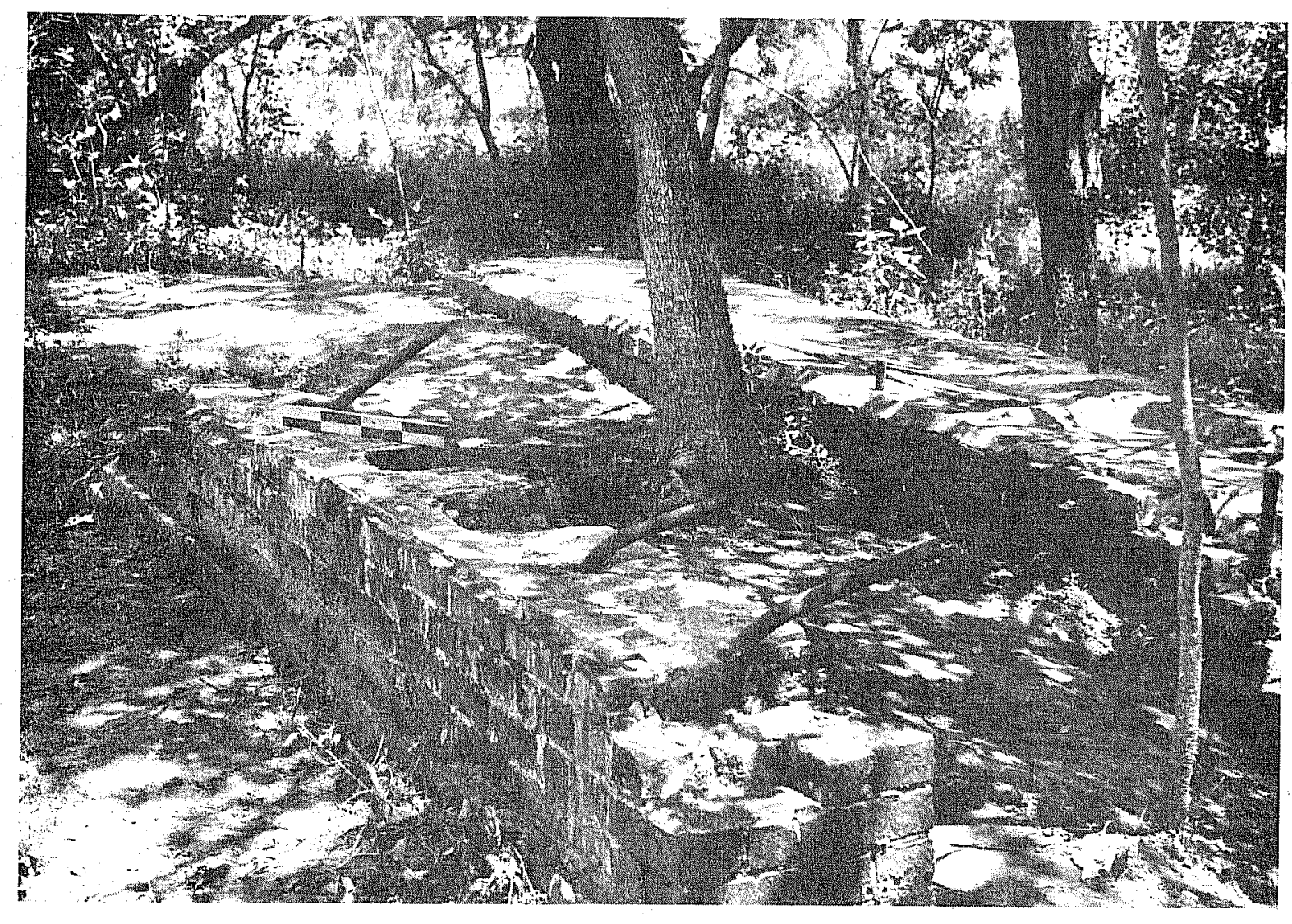

a

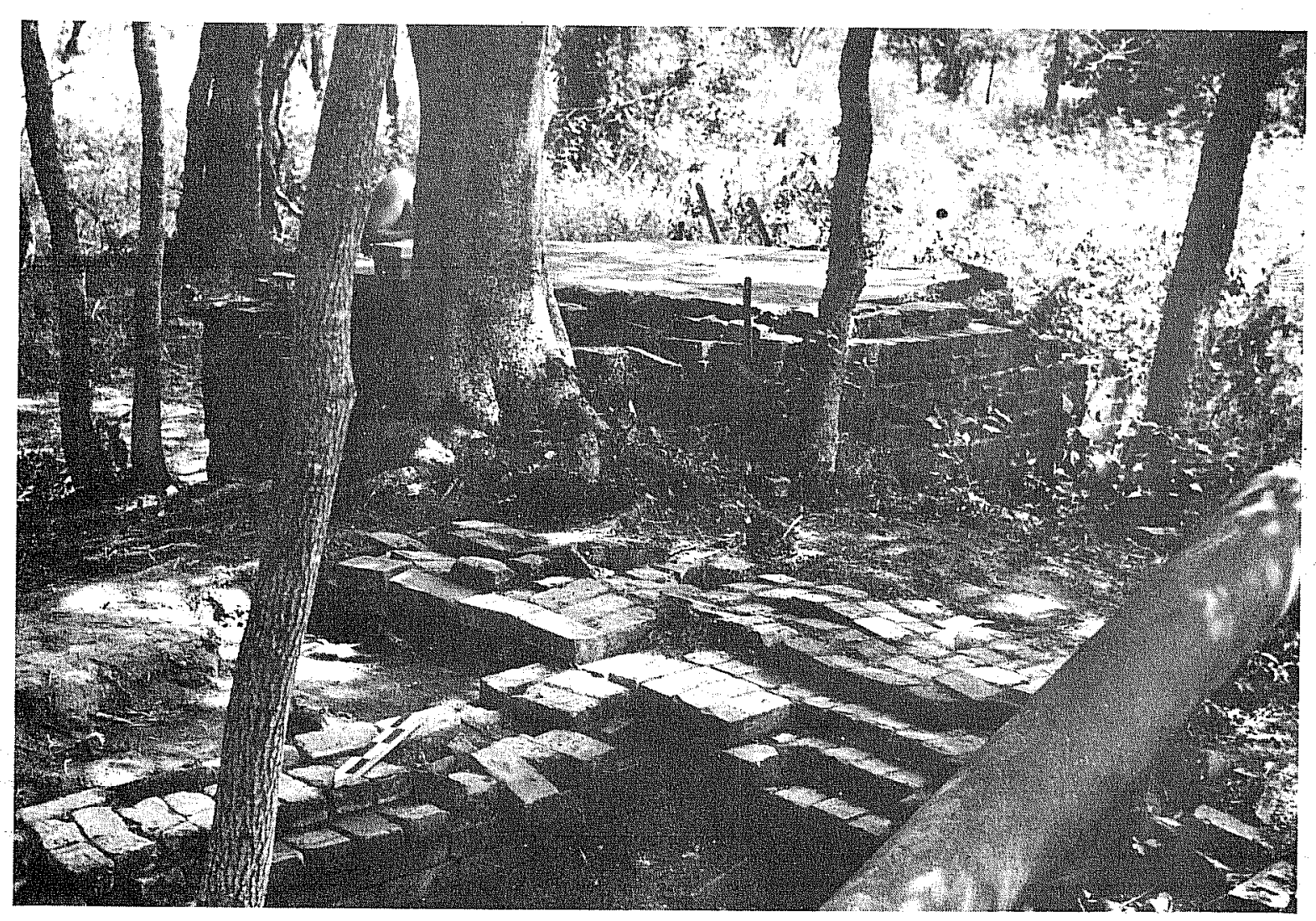

b

Figure 42. Views of Features at Mill. a, looking south across feature 1 toward feature 2; b, looking east across feature 3 . 


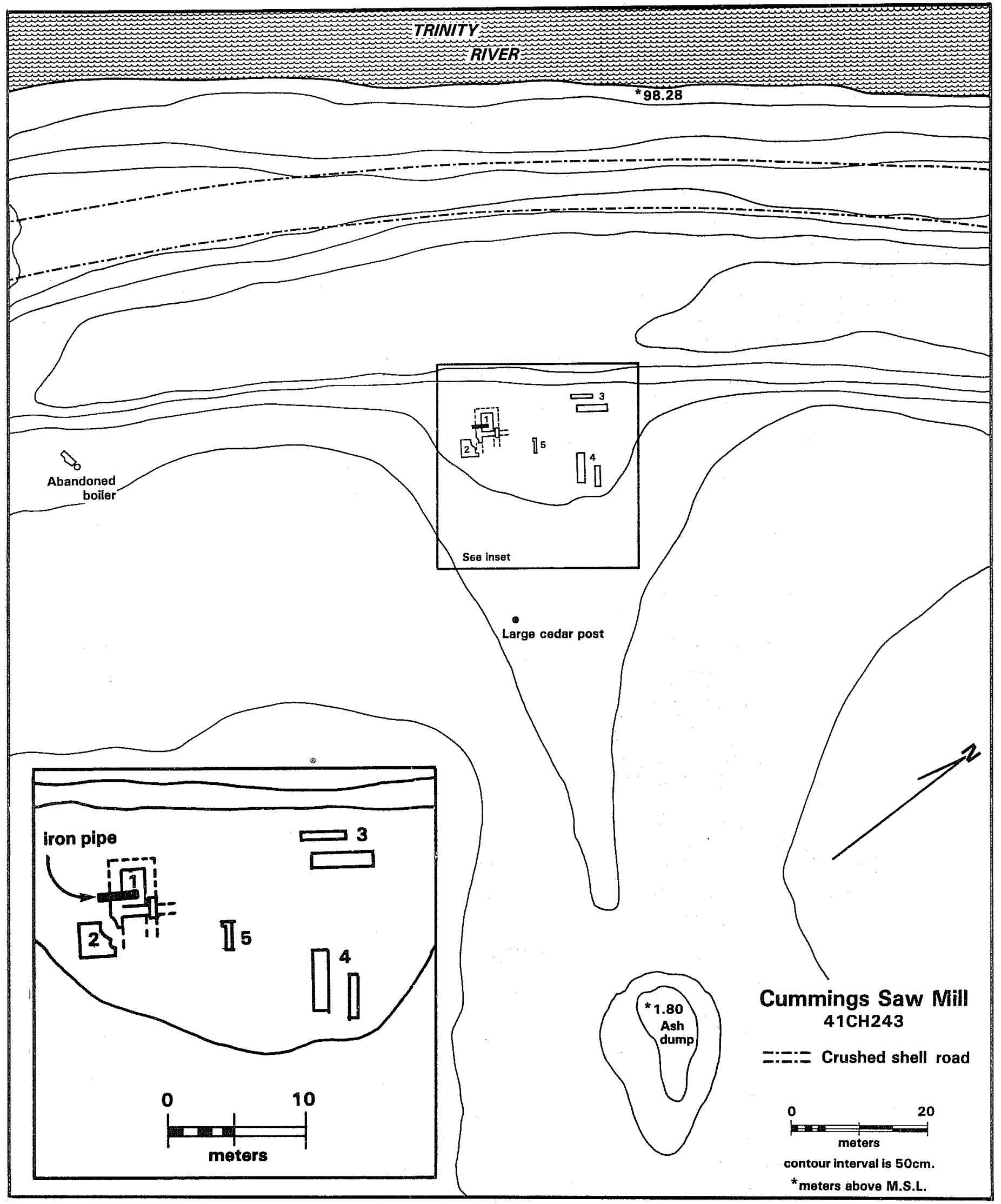

Figure 43. Map of Cummings Mill. Inset is an enlargement of mi11 foundations. 


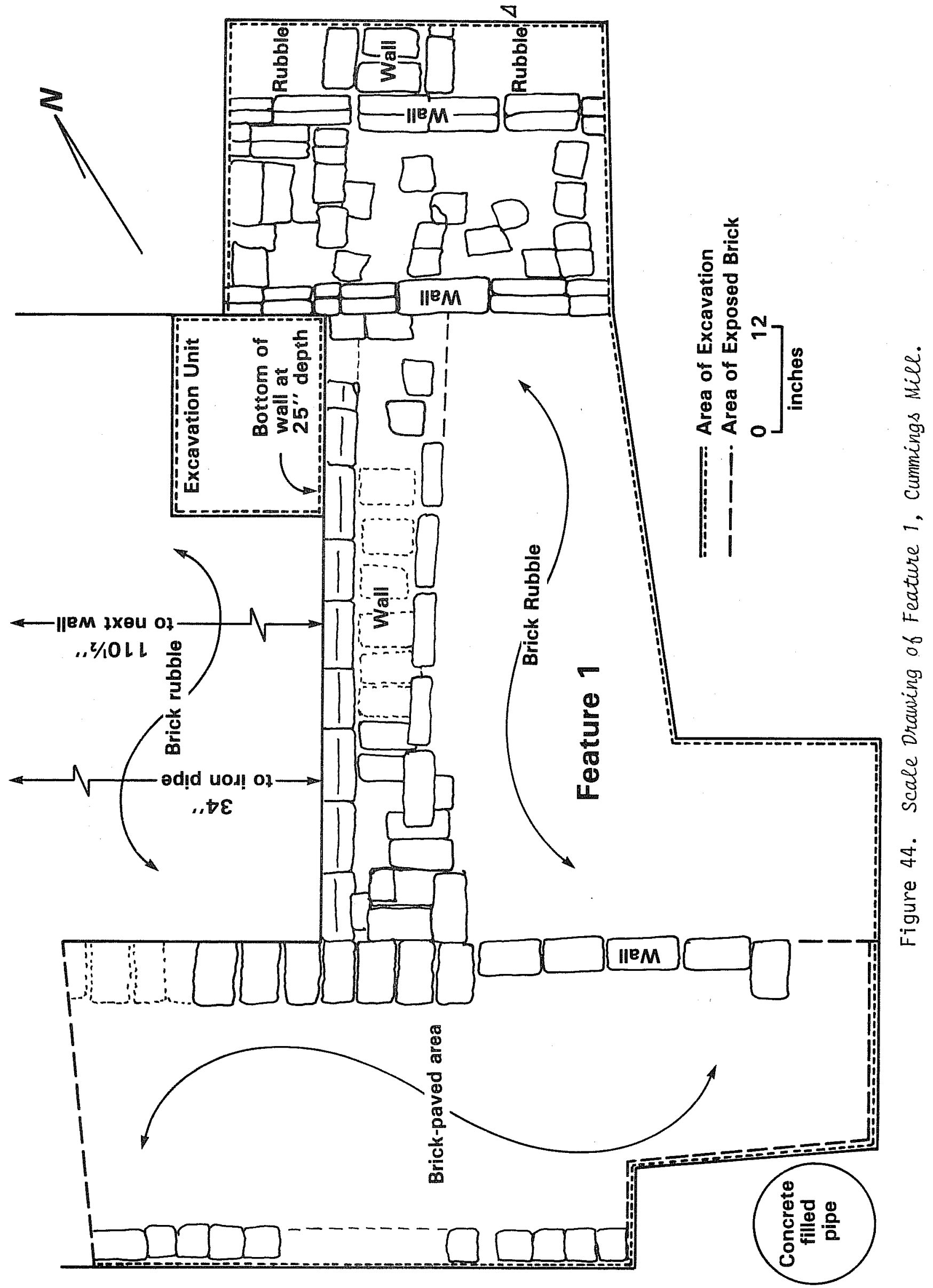



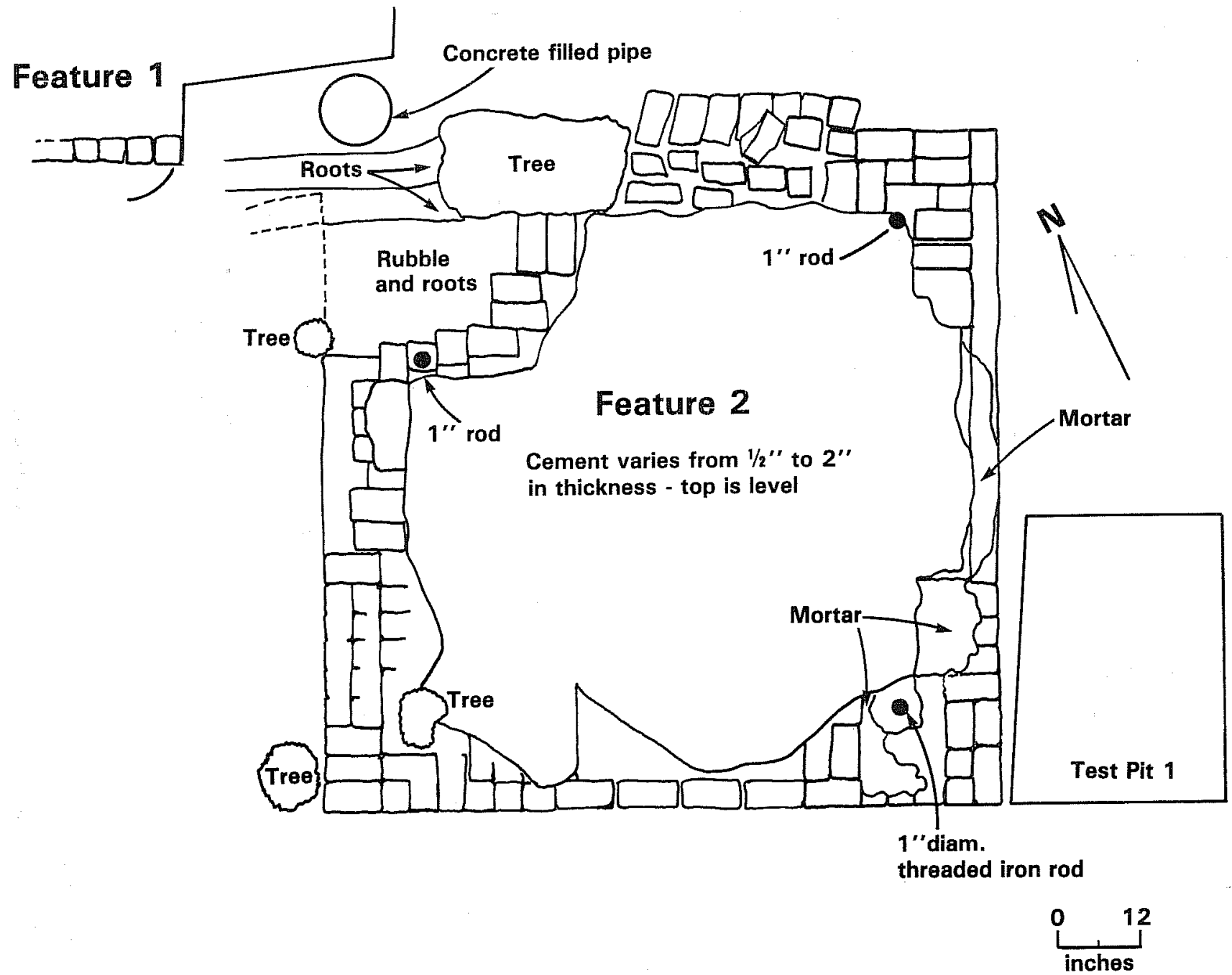

Figure 45. Scale Drawing of Feature 2, Cummings Mill. 
Protruding threaded iron rods indicate that some sort of machinery was once bolted on top of the structure. Its close proximity to Feature 1 suggests a relationship in function between the two. A test pit near the south corner of Feature 2 revealed a stepped base sitting on a brick floor which is now covered with two feet of overburden (Fig. 46). A handful of heavily rusted nails and chunks of iron was recovered from the test pit.

Feature 3 (Fig. 47) is a brick boiler foundation. Two parallel walls of mortared brick approximately four feet apart make up this feature. As with Feature 2, threaded iron rods protrude at regular intervals from the surface of both walls. These are probably the foundation for installation of a boiler and its related flywheel which would have driven the mill machinery. A test pit on the southeast side of the foundation revealed a stepped construction from the present ground surface to the bottom of the structure 3.5 feet below. Evidence for the location of the original floor at approximately 1.75 feet below the surface was a layer of charcoal mixed with clay containing iron artifacts, which rested directly upon a sterile sand layer. Rusted nails and a 2-inch length of heavy glass tubing were recovered from the test pit (Fig. 48).

Feature 4 is identical in most dimensions and details to Feature 3 and therefore was not drawn in detail.

Feature 5 is an exposed section of a low brick retaining wall which forms the northern edge of the mound into which Features 1 and 2 are constructed (Fig. 43).

The majority of the brick found on the site were unmarked, pinkish brown, and measured ca. 2-3/4 $\times 3-3 / 4 \times 8$ inches. A smal1 percentage of those in Feature 2 had a narrow groove running lengthwise down each of the wider faces, but otherwise resembled the plain variety. Scattered on the surface were a few fire brick, of a creamy color with dark rusty brown inclusions, which measured slightly larger, ca. 2-1/4 x 4-1/4 x 8-1/2 inches. A few of the latter were stamped "LECLEDE/ST. LOUIS." Also found on the surface was a fragment of heavy grating made by boring 3/4-inch diameter holes in a sheet of iron 3/4-inch thick. The surfaces of this artifact were covered with a purple deposit.

\section{Observations}

The crew suffered from a distinct lack of information on the operation of a steam saw mi11, which may have caused some oversights in recording the site. The detailed measured drawings and map were done in an attempt to overcome this handicap. The limited testing on the site showed that there is further information to be learned from more detailed excavations, after additional knowledge has been gained on the layout and operation of such a mill. 


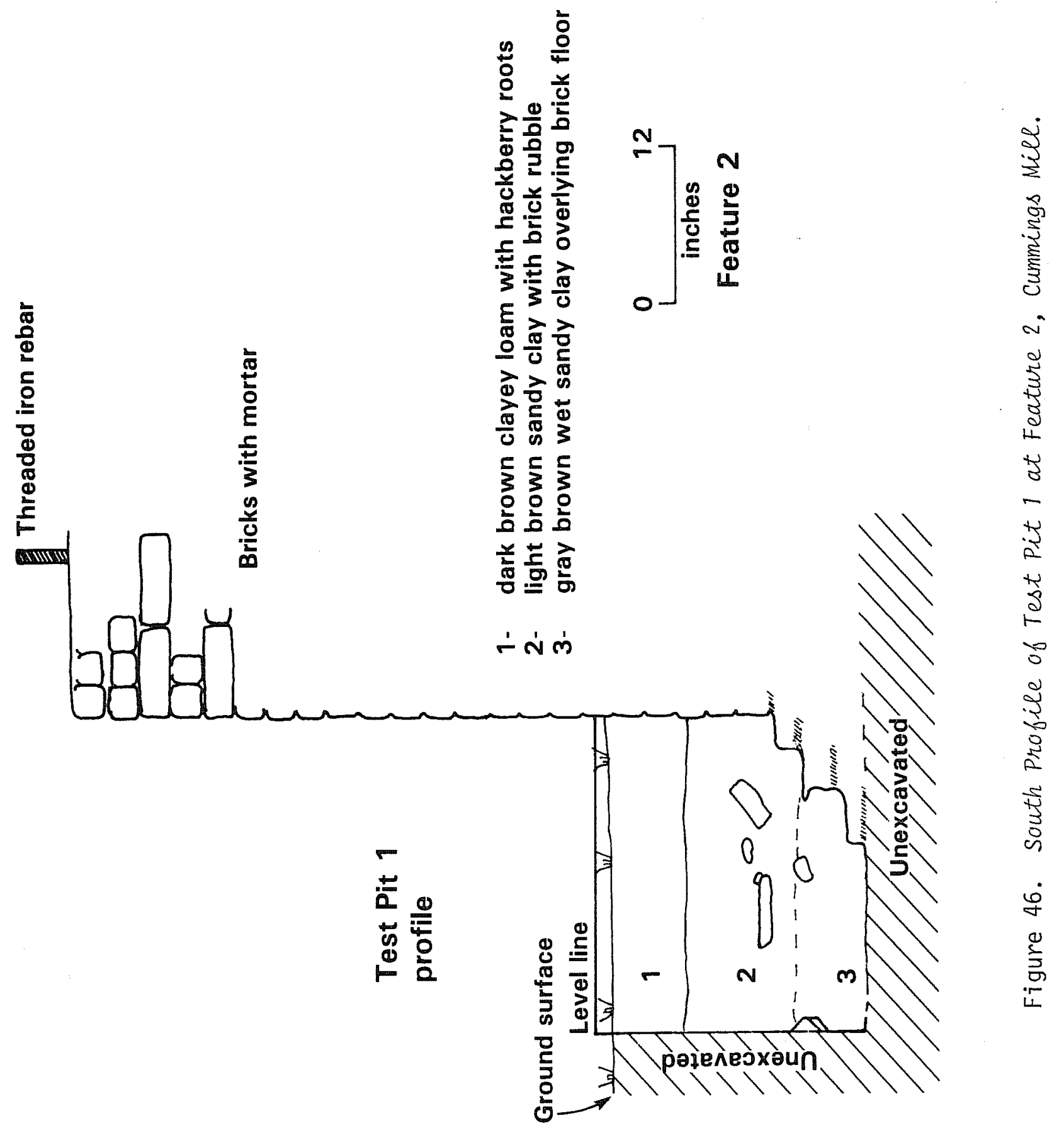




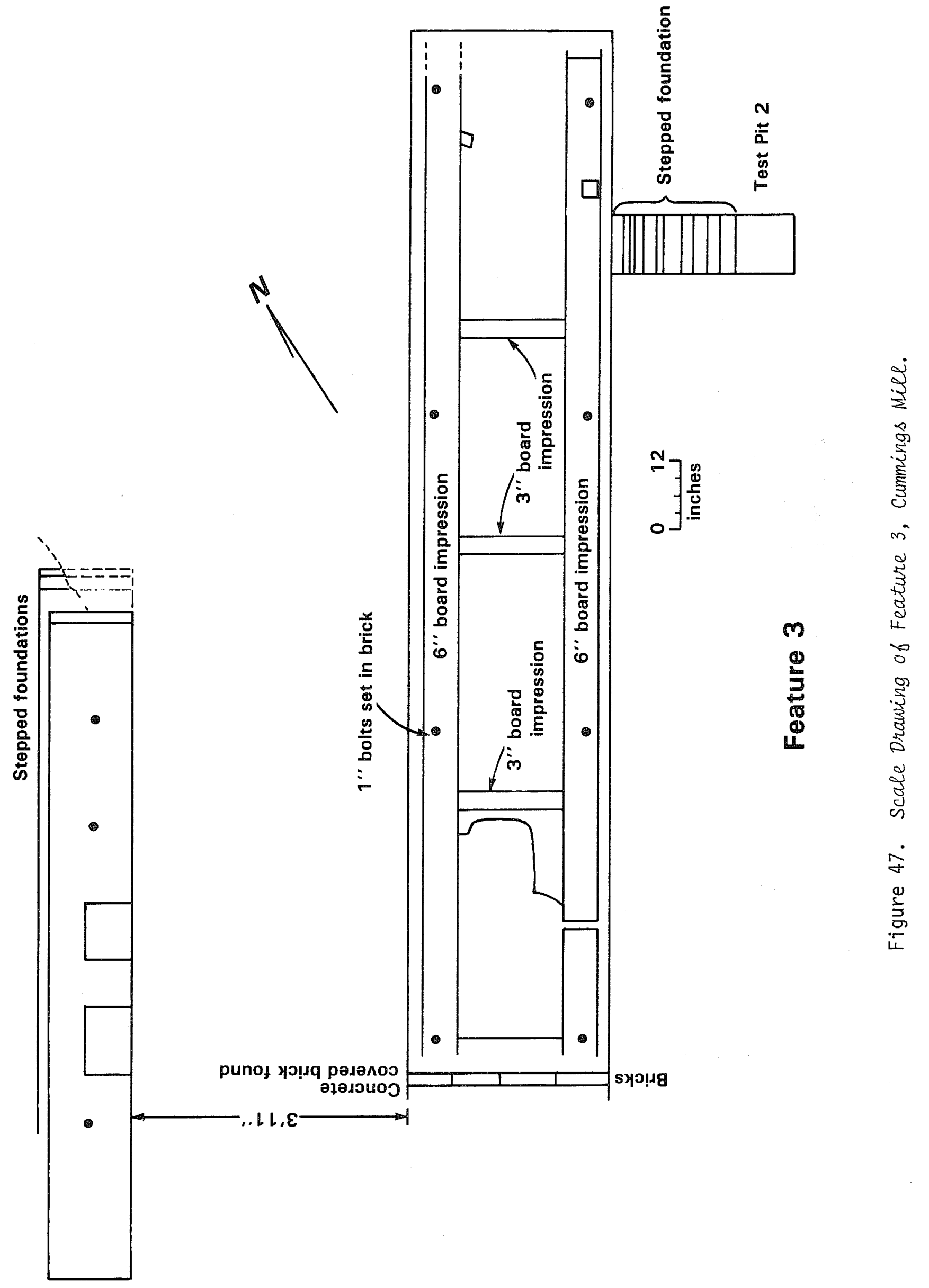




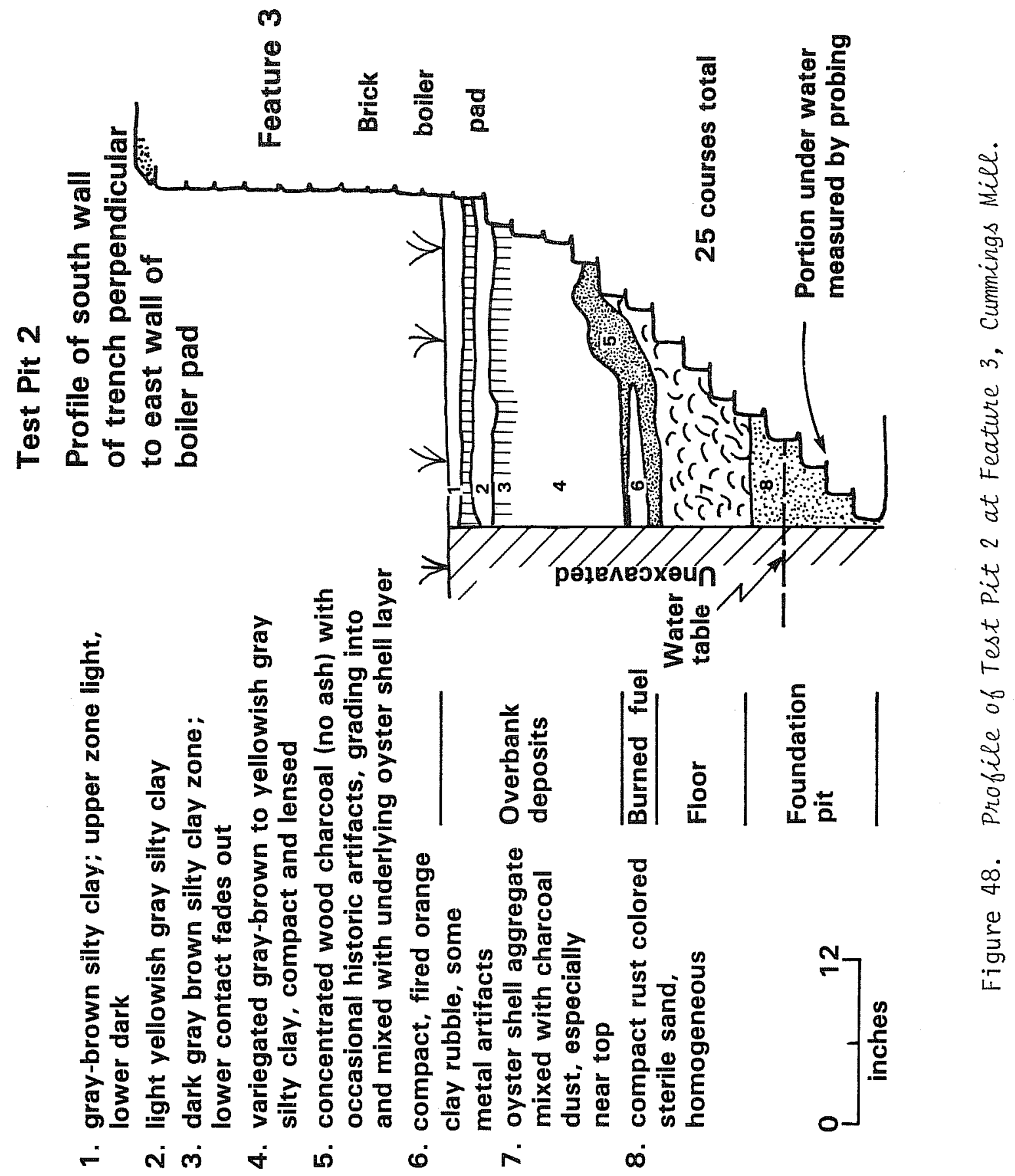




\section{Recommendations}

The Cummings Mill was a most important factor in the growth and development of the town of Wallisville. Archaeological testing has demonstrated that there is a great deal of information still buried under the accumulated soil deposition on the site. A detailed study of the construction and operation of the mill should be a part of the research done in connection with the history of Wallisville itself, and there is interesting potential for research into the social aspects of the impact of the mill workers on the town. Allied with the study of the mill should be investigation of the areas where the workers lived and of the commissary.

We suggest that the site should be included in the Wallisville Heritage Park. If for any reason it becomes necessary to disturb the mill site, we strongly recommend extensive archaeological excavation to recover as much information as possible in any area due to be disturbed.

J. J. Mayes Farm Site, $41 \mathrm{CH} 242$

\section{History}

The Mayes family settled on the west bank of the Trinity River, opposite the later site of the town of Wallisville, about 1838. Joshua Jackson Mayes married Sarah Amelia Dunman, granddaughter of E. H. R. Wallis (Williams et al 1976:n.p.), and accumulated a large amount of land on the west side of the river in his lifetime. A number of houses and outbuildings have been built on and around the original farmstead. The house illustrated in Fig. 49 may well include the first house the family built in the early 19th century, with numerous later additions. In 1883 the Mayes family built a two-story home just east of Wallisville, using some materials from the original home. Mrs. G. V. Mayes lives in this home today (J. B. Mayes, personal communication).

\section{Archaeological Investigation}

Using the Work map of 1930 as a guide (see Fig. 50), the crew surveyed an open area between the two rows of large, old trees which delineated fence lines in an area to the north of the present cattle pens on the property. No trace of structures was found, and no artifacts could be seen on the surface anywhere in this area. However, recent shell road construction may have obliterated such evidence. The area to the southeast of the cattle pens was badly overgrown, and it was impossible to do a thorough survey there. Occasional bricks can be found there, and according to local informants this was the location of the Mayes home, at least within their memory. These same informants remember a barn standing to the west of the pens where the shell road is now (Octavia La Four and J. B. Mayes, personal communication).

observations and Recommendations

It appears that the area has been disturbed by road building and was too overgrown at the time of the 1979 survey to determine its archaeological potential. 


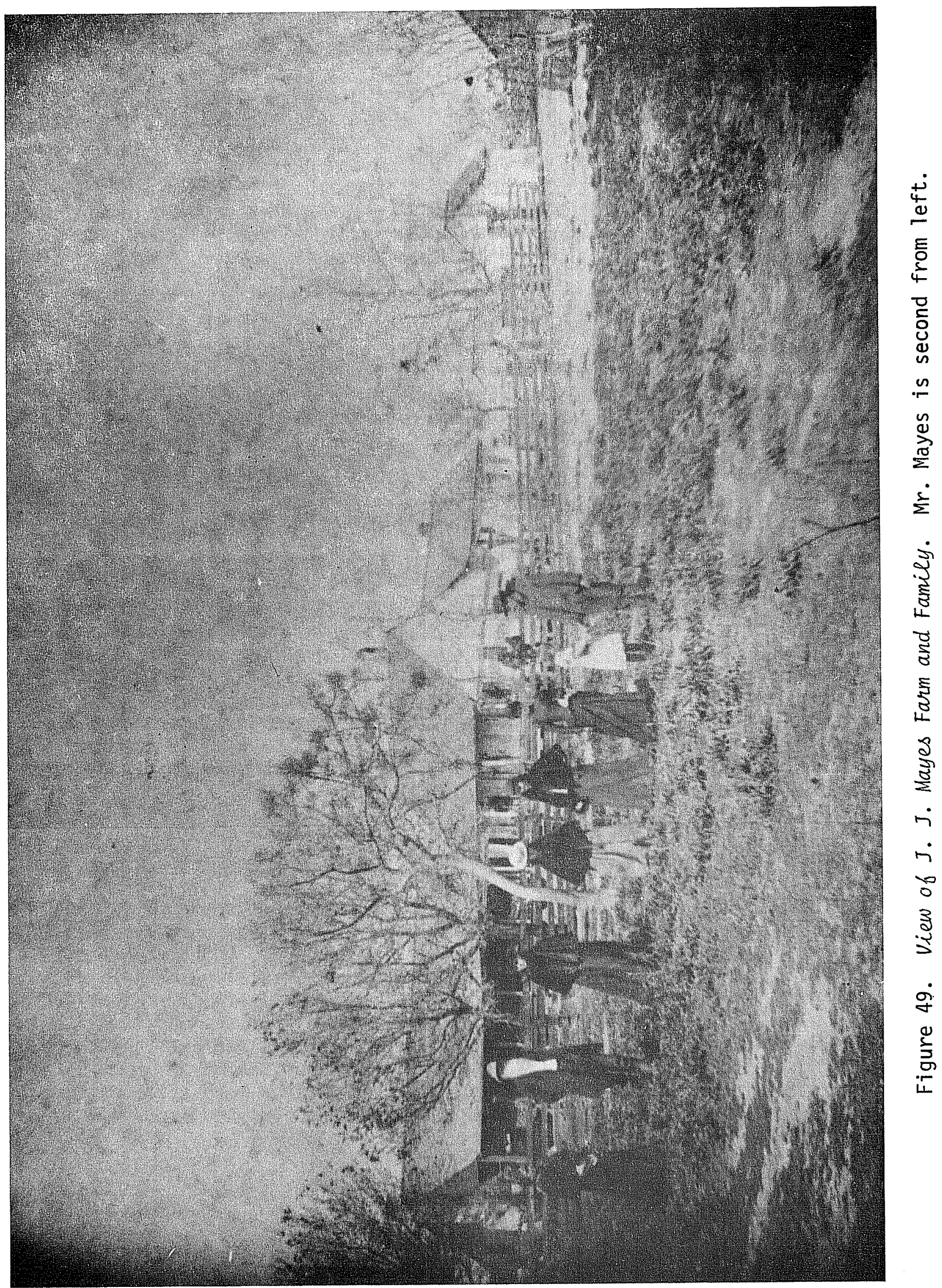




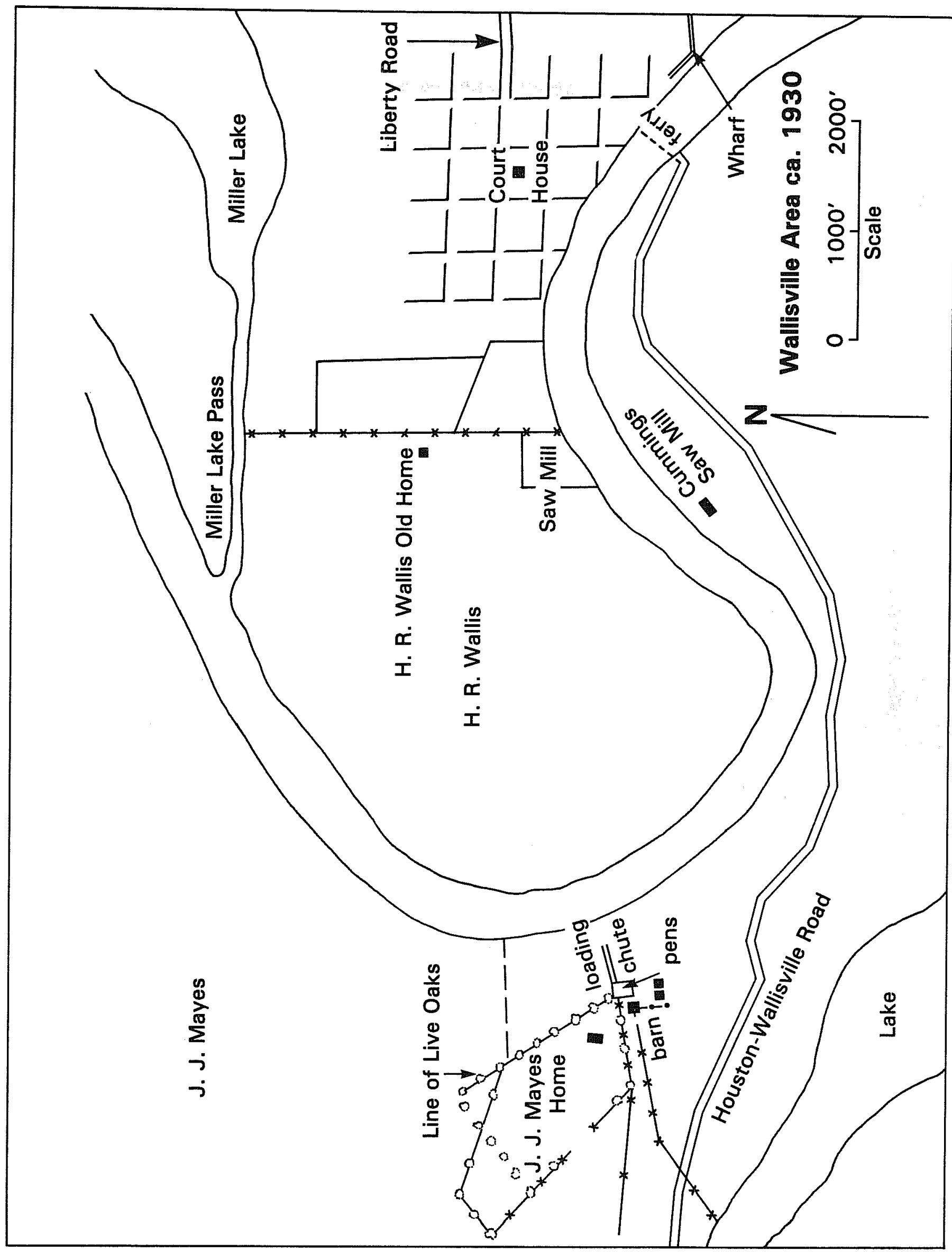

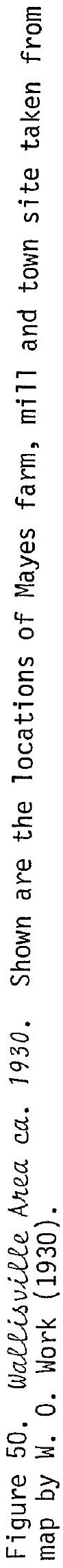


Since the first house was apparently dismantled in the late 19th century, there is probably not much evidence remaining of the original farm.

OLD RIVER

Icet Mi11 and Boat Yard, $41 \mathrm{CH} 244$

\section{History}

Captain William Icet, Sr., was a boat builder and miller in the Cove community in the late 19th century. His shipyard was built in 1880 and continued in operation after his death in 1892 under the direction of his sons, Henry and William (Harry 1940:70). They also operated a cotton gin, a mi17, and a blacksmith shop (Fleischman 1976:237,238). William died in 1915 (CCPR 1915: No. 233), and the shipyard ceased operation at that time.

\section{Archaeological Investigation}

Mrs. Gladys Avery, granddaughter of William Icet and great-granddaughter of Captain Icet, guided a group composed of family members, interested Chambers County people, and the archaeological crew to the site of the Icet mill and shipyard, on the west bank of $01 d$ River.

Pipelines run just north and south of the property, but the Icet site has been preserved. A recently built house sits near the road on the top of the hill, overlooking the site. A number of large trees are present on the property. The site is in a relatively clear and open grassy area on a gentle slope toward the water's edge. Brick foundations are visible here and there in the grass, and an occasional square nail can be found on the surface. Mrs. Avery has a hand-drawn sketch done from memory of the layout of the buildings and rooms in the complex; this sketch should be preserved.

observations and Conclusions

It appears that the layout of the shipyard and mill could be reconstructed on paper, using a combination of archaeology, historical research, and family papers.

\section{Recommendations}

While the site is not of national or statewide importance, it is an unusually we17-preserved archaeological site which could yield much information, and it is of importance in the local history of Chambers County. We recommend that more research and a program of archaeological testing be undertaken to determine its eligibility for nomination to the National Register. 


\section{A1meras Brick Works, $41 \mathrm{CH} 231$}

The early ownership of this property is confused and difficult to trace. It was original7y a part of the Robert Wiseman Survey, a portion of which, after many changes of ownership, came into the hands of Dr. James P. Alford in 1872 (Mullins n.d.:2). That same year Dr. Alford deeded 100 acres of the Robert Wiseman Survey to Pierre Almeras, Louis Guertin, and Euclide Brisson (CCDR 1872:H,42). Apparently Almeras then proceeded to build a large-scale brick-making operation on the portion of the property which fronted on 01d River, for in 1875 Almeras gave $\mathrm{Dr}$. Alford his power of attorney to take control of his interest in the brickyard and 100 acres owned by himself and Guertin, and to sell the brick (Almeras 1875). Apparently the brickyard was a short-lived business, since it was not mentioned in the 1870 or the 1880 census reports, nor in any other records or newspaper accounts so far examined (Villa Mae Williams, personal communication). This is surprising considering the extensive layout which is visible in ruins on the surface of the site.

Apparently the brickyard was allowed to fall into ruin, while being slowly covered with alluvium from flooding and robbed of usable bricks. No trace of structure remains today except what portions of the wal1s were quickly buried in mud and the rubble of broken and rejected bricks which had been piled around the outside of each kitn.

The wallisville Age of May 11, 1898, carries a brief mention of charcoal burning on the west side of the river. While no specific mention is made of this activity on the A7meras property, there are several circular areas of deeply burned clay soil in the vicinity of the brick kilns which may have resulted from charcoal burners' fires.

\section{Archaeological Investigation}

This site was first investigated and recorded by $W$. L. Fullen and Jean L. McGinty in 1978. At this time eight kilns and three burned areas were noted, as well as two possible borrow areas (McGinty 1978). The site was registered with the Texas Archeological Research Laboratory in Austin and assigned site number $41 \mathrm{CH} 231$.

The exact location of the westernmost kiln in relationship to the boundary of the Corps of Engineers property line could not be readily determined. It was decided by the present investigators to establish the location and size of the structure in order to later determine how much of the site belongs to the Corps and how much is on private land.

Probably the one factor which has done the most to protect this site is the dense underbrush which covers most of the kiln area. The river bank is heavily used by fishermen and campers, and roads have been worn through the brush. The kiln chosen for testing is the one most likely to be disturbed by the public, since an access road cuts across it, exposing crumbling bricks in the road bed, and it is the closest kiln to the river.

Each of the kilns appears on the surface as a circular ring of mounded brick rubble and soil. The underbrush was selectively cleared from this mounded area on the kiln to be tested, taking out only what was necessary to the investigation. 
This was done in order to avoid arousing public curiosity about the structure and to insure that the protective growth would rapidly hide the kiln when the work was finished.

Three trenches were laid out at various locations perpendicular to the mound (Fig. 51), trenches $A$ and $B$ across the west side and $C$ across the south. As excavation progressed, it was discovered that the mounds actually were not the walls of the kiln but piles of broken bricks and soil, which probabiy represent the covering removed after the kiln had cooled and the bricks were being removed from the kiln. Just inside the mound was the outer wall of the kiln. On the inside of this wall there remained a layer or two of a row of fired bricks which had never been removed (Fig. 52). The shape of the kiln was found to be square rather than round as first believed. The parallel rows of bricks were laid out north-south, with the "eyes" of the kiln on the north and south ends (see Appendix I). This was confirmed by expanding trench C slightly to the west to uncover one bricked-up opening in the south wall (Fig. 51).

Since the road cutting through the site had changed the original contours, it was difficult to determine where the east wall of the kiln might be. Trench $D$ was laid out across a similarly mounded feature to the east of the road in the possibility that the wall might be there. However, no wall was encountered, and when the trench approached the point of disrupting the road bed, it was discontinued. A row of bricks which appeared to be in place was exposed in the road bed at the point where the north wall of the kiln was estimated to be, and a band of brick rubble was eroding from the road bed on a line with the mound outside the south wall. Unit $E$ was a shallow, rectangular excavation to examine the original floor of the kiln, which was found to be $10 \mathrm{~cm}$ below the surface at this location. At $10 \mathrm{~cm}$ the brown, sandy soil changed to a bright orange clay, showing the effects of the heat of the kiln on the clay subsoil. The same orange clay surface was encountered on the inside of the kiln in trench $B$, whereas the clay subsoil on the outside of the wall in this trench was observed to be the tan-to-dark-brown color of the normal clay in this area.

A datum was established by driving a nail into a tree on the northeast corner of the site and assigning to this the arbitrary height of $100 \mathrm{~m}$. The kiln site and its immediately surrounding area were mapped using a plane table and alidade (Fig. 51).

Near the kiln at the bank of the river several semicircular intensively burned areas were examined. Evidence of intense heat was visible to a depth of 10 or more $\mathrm{cm}$ into the clay, creating an appearance not unlike a brick pavement. These may be areas where charcoal was burned for shipping to Galveston and Houston in the late 19th century.

\section{observations and conclusions}

Projecting the confirmed wall locations, it is possible to reconstruct the outline of the kiin. It would have been approximately 35 feet square. Approximately 15 meters to the north was a depression 1ocal7y reputed to be a cistern used by the brick works. Seven similar kilns are laid out in a double row to the east of the one recorded, indicating an unusually ambitious operation was going on here in the 1870s. Perhaps Mr. Almeras over-extended himself. 
This page has been

redacted because it

contains restricted

information. 


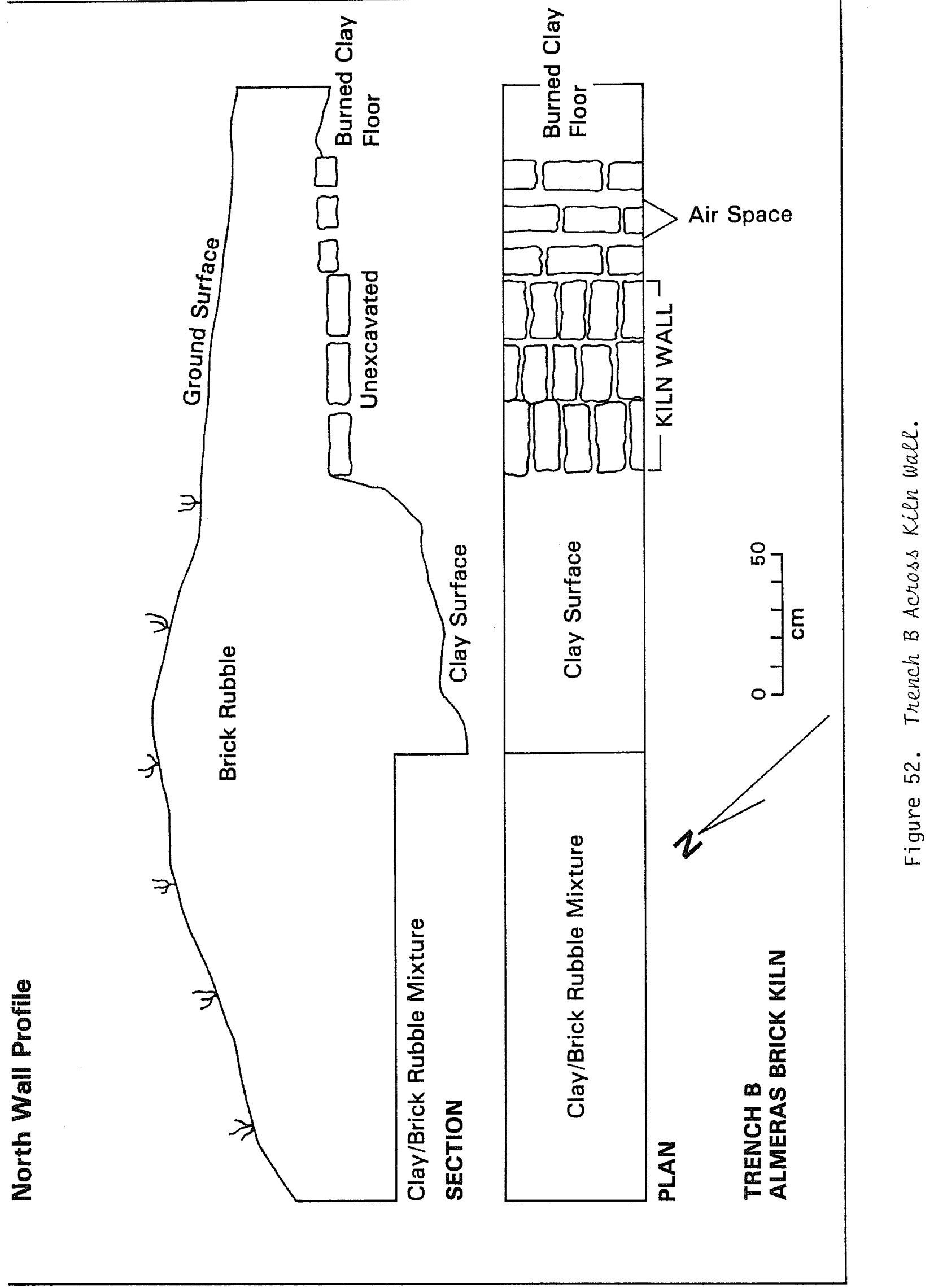


It is apparent that a great deal of information about the local brick industry could be learned from an extensive study of this site. Careful observation and selective clearing of the underbrush would allow the entire layout to be mapped, and possibly the areas given over to brick forming and drying could also be found and studied. Further archival research would undoubtedly reveal old photographs and documents dealing with similar operations of this period.

\section{Recommendations}

This is obviously an important site which shows great potential for further research. Unfortunately, very little is known about the brick-making industry in Texas, despite numerous historic references to kilns in operation. The site is presently endangered because of public use of the area. We recommend that the Corps of Engineers cooperate with the landowner who owns the balance of the site in nominating it to the National Register and protecting the area from vanda 7 ism.

The Coffee Site, $41 \mathrm{CH} 103$

History

This she 11 midden site was recorded in 1968 by W. L. Fullen (1968). It covers an area approximately $40 \times 140$ feet, and the deposits are 12 to 18 inches deep. Members of the Houston Archeological Society and the previous landowner have recovered prehistoric sherds, 1ithic debris, flintlock gun parts, a gun flint, and glass trade beads from the surface, after a portion was plowed by the landowner. A burial was also removed, but has since been misplaced (W. L. Fullen, personal communication). Detailed drawings of these artifacts are filed with the site survey form at the Texas Archeological Research Laboratory in Austin.

\section{Archaeological Investigation}

The site was examined briefly, and the following artifacts were recovered from the surface:

7 sand-tempered sherds

18 sandy paste untempered sherds

16 chert flakes

2 petrified wood flakes

1 flat chert pebble with flakes removed

1 baked clay lump

1 blue glass bead (Fig. 26,a). 
Observations and Conclusions

The bead can be classified, according to Harris's system, as a No. 13, large, dark Bluebird Blue, translucent, olive-shaped necklace bead of simple construction, tumbled (Jelks 1967:100), which dates to the mid-18th century (ibid.:

104). Identical beads have been found on the Gilbert site in Rains County (Jelks 1967:104) and the Womack site in Lamar County (Harris et al 1965:309). This bead is said to be identical to those found previously on the site. The gun parts recovered were from the same period.

On the basis of the artifacts recovered from the site over the years, there is little doubt that it was occupied in both prehistoric and historic times.

\section{Recommendations}

We believe that this site shows more promise of containing additional evidence of the period of Orcoquisac contact with the Europeans than either 41 LB 4 or $41 \mathrm{CH} 110$ (Gilmore 1974:1), which were included in the Orcoquisac Historical District. For this reason, plus the fact that the site is more easily accessible and appears to be partially undisturbed, we recommend that the site be nominated to the National Register of Historic Places. 


\section{SUMMARY AND RECOMMENDATIONS}

During July and August 1979 the Center for Archaeological Research conducted survey, testing, and historical research on lands to be included in the wallisville Lake in Liberty and Chambers Counties, Texas. A total of 31 previously recorded sites was examined, and 16 new sites were recorded. Twenty-one prehistoric sites due to be within the proposed Plan $2 A$ were assessed for possible impact of the reservoir, and recommendations have been made for mitigation of some of these sites. Nineteen historic period sites were examined and their comparative importance determined through historical research and archaeological testing. Recommendations have been made for nomination of certain sites to the National Register of Historic Places, and for protection of sites which will be threatened with serious erosion by the construction and maintenance of the reservoir.

Area of PIan 2A

Section II of this report includes recommendations for possible mitigation of certain sites. However, we feel that the final decision regarding such mitigation should be made by a group which includes a representative of the State Historic Preservation officer and one or more of the archaeologists who participated in the original surveys of the reservoir as a whole. In this way, decisions can be made from the point of view of the potential of the entire lower Trinity Valley, rather than the necessarily narrow view which was obtained by this survey. For this reason, our recommendations are based on the necessity to establish the relationships of large and small, valley wall, and flood plain sites to each other and to sites tested in earlier surveys which were located farther downstream and in potentially different situations.

The recommendations for historic sites within the proposed reservoir are included in Table 15. Our conclusions were reached after a great deal of thought and discussion, taking into consideration the probable primary and secondary effects of the reservoir on the area as a whole, the history of Chambers County and its immediate surroundings, and its relationship to the history of the state.

The statement that no additional work need be done at present is intended to indicate that there is still research and investigation potential at the site for others, such as the Chambers County Historical Commission or interpretive researchers for park displays to pursue in the future. Where protection is advocated, we recommend that some means be devised to stabilize presently eroding bank areas and to minimize wave action against these areas when the water level is raised to maximum level. Public use of these areas should also be discouraged.

These factors are particularly important in the Orcoquisac Historic District. Since archival research has reaffirmed that a French ship lies somewhere near the first presidio site $(41 \mathrm{CH} 57)$ and recent magnetometer testing suggests that this method of search would yield accurate results, a thorough, professional magnetometer survey should be undertaken to find the location of the ship. This should be done in order to avoid damaging the remains by any bank stabilization or other construction undertaken to protect the bank from wave action. Carefui 
TABLE 15. ANALYSIS OF HISTORIC SITES

Site

Brick Kiln (41 CH 232)

McFaddin Marker

(41 $\mathrm{CH} 233$ )

Labadie Site

(4) $\mathrm{CH}$ 62)

Munger Site

(41 CH 234)

Presidio San Augustin I (41 CH 57)

Orcoquisac Camp

(41 $\mathrm{CH} 22$ )

Mission La Luz

(41 $\mathrm{CH} \mathrm{54)}$

Presidio San Augustin II

(41 $\mathrm{CH} 53$ )

Wallisville townsite

Cummings $\mathrm{Mi} 11$

(41 $\mathrm{CH} 243$ )

J. J. Mayes Farm

(41 CH 242)

Shipwreck in Lake Miller Further silting

Icet Mill and Boat Yard None

(41 $\mathrm{CH} 244$ )

A]meras Brick Works

(41 CH 231)

Coffee Site

(41 CH 103)
Effects of Reservoir

None

None

Erosion, bank

collapse

None

Erosion, flooding

Erosion, bank

collapse

None

Public access

Flooding

Flooding

Flooding

Public Access

None
Recommendations

National Register

No further work at present

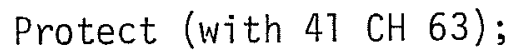

National Register

No further work at present

Protect; magnetometer survey

Protect

Protect; no further work at present

Protect

Study; Historic District

Research and excavation

No further work

No further work at present

Further research by Chambers County; no further work at present

Protect; National Register

National Register 
documentation of the wreck location would make possible a future excavation of this ship as part of an overall research plan for the area.

Also, there seems little doubt that there is a shipwreck somewhere in the northwest quadrant of Lake Miller, possibly by this time buried in the silted-in area of the lake. While this is an extremely interesting historical resource, no new threat is posed to it by reservoir construction. If a magnetometer survey is undertaken at $41 \mathrm{CH} 57$, it might be worthwhile to also locate this wreck for future reference.

Concerning the town of Wallisville, the problem of flooding needs further study, as suggested above. We recommend that the town be made a Historic District, and that this be made the interpretive center for the reservoir. Use of a renovated structure from the old town or a building such as the proposed courthouse reconstruction would be an ideal setting and would form the nucleus for development of an attractive park on the town site. The combination of a Wallisville Heritage Park with the Orcoquisac Historic District would allow the study of several thousand years of history in one location.

The site of the Cummings Mill offers several alternatives. As mentioned previousiy, although this was once an important industrial site, much of it has been severely disturbed during construction of the road which now runs between the mi11 and the river. Construction of a dike on this location would visually cut off the mill site from the town to which it was so closely related. On the other hand, if the dike were built west of the mill, the site would frequentiy be flooded. Therefore, it seems that the most practical course in the event that the reservoir is constructed as planned would be to extract as much information as possible from the site through research and excavations for use in an interpretive program on the Wallisville town site. Future reservoir construction would make it inaccessible for use as a part of the park.

The combination of a large, rich prehistoric site ( $41 \mathrm{CH} 62$ and $41 \mathrm{CH} 63$ ) and a historic site which involves a well-known participant in the Texas Revolution merits consideration of the Labadie site for the National Register. If future plans call for a recreational park in this area, we urge that access to the water be at the gently sloping shoreline near the Munger site and that any concentrated foot or vehicular traffic be routed around the bluff at the Labadie site as much as possible in order to avoid further erosion.

Area Outside P1an 2A

The reasons for recommendation that the Almeras Brick Works and the Coffee site be nominated to the National Register have been explained above. Research into the history of the Icet Mill and Boat Yard might properly be carried out by the Chambers County Historical Commission, with the possibility considered that it may merit nomination to the National Register.

Since no archaeological sites were found to be located within the general areas designated for control structures, we foresee no particular archaeological problems with their construction. However, in this and in all construction work done in connection with the proposed reservoir, we strongly urge care on the part of contractors and consultation with a professional archaeologist should any type of human occupational remains be found. 


\section{REFERENCES CITED}

Almeras, Pierre

1875 Power of Attorney, February 27. Gaiveston. Copy in files of Chambers County Historical Commission, Anahuac.

AmbTer, J. R.

1970 Additional Archeological Survey of the Wallisville Reservoir Area, Southeast Texas. Texas Archeological Salvage Project, Survey Report 6.

1973 Excavation in the Trinity River Delta: The Lost River Phase. Texas Archeological Survey, The University of Texas at Austin.

Aten, Lawrence E.

1967 Excavations at the Jamison Site (41 LB 2), Liberty Co., Texas. Houston Archeological Society, Report 1.

1979 Aboriginal Culture Ecology of the Upper Texas Coast. Ph.D. dissertation, The University of Texas at Austin.

Barker, E. C.

1965 Mexico and Texas 1821-1835. Russe11 and Russe11, New York. Blair, W. F.

1950 The Biotic Provinces of Texas. Texas Journal of Science 2(1):93-117. Bolton, H. E.

1970 Texas in the Middle Eighteenth Century. University of Texas Press, Austin and London.

Brown, Kenneth L.

1979 Letters to Col. John Vanden Bosch, District Engineer, U.S. Army Corps of Engineers, Galveston. February 5.

Burch, Marvin C.

1950 A History of the Lower Trinity River Region of Texas to 1836. Unpublished M. A. thesis, The University of Texas at Austin.

Burt, W. H.

1952 A Field Guide to the Mammals, Giving Field Marks of All Species Found North of the Mexican Boundary. Houghton Mifflin, Boston. 
Campbe11, T. N.

1957 Archeological Investigations at the Caplen Site, Galveston County, Texas. Texas Journal of Science $9(4)$.

Castañeda, Carlos E.

1939 Our Catholic Heritage in Texas 1519-1936. The Mission Era: The Passing of the Missions 1762-1782. Volume IV:46-98. Von BoeckmanJones, Austin.

Chambers County Herald

1900 Advertisement for Davis Store. December 1.

Clay, John $\mathrm{V}$.

1977 Spain, Mexico, The Lower Trinity. Available from the Copy Cat Company, Liberty.

Conant, Roger

1975 A Field Guide to Reptiles and Amphibians. Houghton Mifflin, Boston. Corps of Engineers

1928 Anahuac, Texas; Tactical Map. Scale: 1/125,000. Surveyed 1910-11, revised 1922 and 1928. U.S. Army Corps of Engineers.

Corps of Engineers, Gaiveston District

1977 Public Information Brochure, Wallisville Lake, Texas. Prepared for a public meeting in Anahuac, Texas, December 10.

1979a Contract No. DACW 64-79-C, Draft Appendix A, with Center for Archaeological Research, The University of Texas at San Antonio, 1 June.

1979b Draft Environmental Statement, Trinity River Navigation Project, Texas.

Davis, W. B.

1974 The MammaTs of Texas. Revised edition. Texas Parks and Wildlife Department, Bulletin 41.

Dillehay, Tom D.

1975 Prehistoric Subsistence Exploitation in the Lower Trinity River Delta, Texas. Texas Archeological Survey, Research Report 51. 
Eddy, Samue 1

1957 The Freshwater Fishes. Wm. C. Brown Co., Dubuque.

Fehrenbach, T. R.

1969 Lone Star. The MacMillan Company, Toronto, Ontario.

Fenneman, N. M.

1938 Physiography of the Eastern United States. McGraw-Hi11, New York. Fleischman, Flavia

1976 Old River Country: A History of West Chambers County. Miran Publishers, Fort Worth.

Fox, Carl

1973 The Doll. Harry N. Abrams, Inc., New York.

Fullen, W. L.

1966 Site $41 \mathrm{CH}$ 54. Site Survey Form. Texas Archeological Research Laboratory files, Austin.

1968 Site $41 \mathrm{CH}$ 103. Site Survey Form. Texas Archeological Research Laboratory files, Austin.

1979 An Alternative to the Navigation Channel Through the Wallisville Heritage Park. Letter from Mrs. Jean McGinty to Lt. Col. Charles W. Lively, September 17.

Galveston Weekly News

1853 Article about Clarke and Kilgore sawmi11. December 20, page 1.

General Land Office

1964 An Abstract of the Original Titles of Record in the General Land Office. Niles \& Co., Houston, 1938. Reproduction by Pemberton Press, Austin.

Gi Imore, Kathleen

1974 Cultural Variations on the Texas Coast: Analysis of an Aboriginal She11 Midden, Wallisville Reservoir, Texas. Texas Archeological Survey, Research Report 44.

G]assie, Henry

1975 Archaeology and Folklore: Common Anxieties, Common Hopes. In Leland Ferguson, ed., Historical Archaeology and the Importance of Material Things. Society for Historical Archaeology, Special Publication Series 2:23-35. 
Godden, Geoffrey A.

1964 Encyclopaedia of British Pottery and Porcelain Marks. Bonanza Books, New York.

Gordon Family Record

n.d. Record of the Gordon Family Compiled From the 01d Family Bible. Copy in files of Chambers County Historical Commission, Anahuac.

Gordon, George

1873-79 Diary kept by the George Gordon Family. Copy in the files of the Chambers County Historical Commission, Anahuac.

Ha11, R. L.

1949 Map of Wallisville, Texas. Prepared by R. L. Hal1, State Land Surveyor. Aprit 4.

Harris, R. K. and I. M. Harris

1967 Trade Beads, Projectile Points, and Knives. In A Pilot Study of Wichita Indian Archaeology and Ethnohistory (compiled by Robert E. Be11, Edward B. Jelks, and W. W. Newcomb). Report to the National Science Foundation, Grant GS-964.

Harris, R. K., Inus Marie Harris, Jay C. Blaine, and Jerrylee Blaine

1965 A Preliminary Archeological and Documentary Study of the Womack Site, Lamar County, Texas. Bulletin of the Texas Archeological Society 36:287-363.

Harry, J. H.

1940 History of Chambers County. M.A. thesis. The University of Texas, Austin. Typescript on file at Chambers County Historical Commission.

Hayes, Charles $W$.

1974 Galveston, History of the Island and the City. Two volumes. Jenkins Garrett Press, Austin.

Hester, T. R.

1971a A Note on Baked Clay Objects from the Texas Coast. Institute of Archeology and Anthropology. The University of South Carolina, Notebook 3(1):15-17.

1971b Loyola Beach: An Example of Aboriginal Adaptation to the Maritime Environment of the Lower Texas Coast. Florida Anthropologist 24 (3):91-106. 
Hoese, H. D. and R. H. Moore

1977 Fishes of the Gulf of Mexico. Texas A\&M University Press, College Station.

Hotchkiss, David

1966 Spanish Missions of Texas. D. S. Hotchkiss, Corpus Christi. Howe 11, C. W. and H. M. Adams

1873 Survey of Trinity River. Map made under the direction of Captain Howe 11 and Lieutenant Adams, October 1872 to January 1873. Sheet No. 5. U.S. Engineers.

Hubbs, Clark

1976 A Checklist of Texas Fishes. Texas Parks and Wildlife Department, Technical Bulletin 11.

Jelks, Edward B., ed.

1967 The Gilbert Site. Bulletin of the Texas Archeological Society 37 (entire volume).

Katz, Paul R.

1978 Archaeological and Historical Investigations in the Arciniega Street Area, San Antonio, Texas. Center for Archaeological Research, The university of Texas at San Antonio, Archaeological Survey Report 61.

Kendrick, Grace

1967 Bottle Fragments Betray Age of Historical Sites. El Palacio 74(2): 19-24.

Labadie, N. D.

1839 Letter to Anthony Lagrave, St. Genevieve, Missouri. Rosenberg Library No. 22-0017.

Laffite, John A., editor and translator

1954 The Journal of Jean Laffite. Vantage Press, New York.

La Grange Journal

1940 A Hero of the Texas Revolution: Robert Oson William McManus. August 22, page 6 .

Lewis, Carrol1

1977 The Treasures of Galveston Bay. Texian Press, Waco. 
172

Liberty Vindicator

1895 Article on Wallisville news. September 20.

1906 The Ball at Wallisville. August 24.

Lorrain, D.

1968 An Archaeologist's Guide to Nineteenth Century American Glass. Historical Archaeology 2:35-44.

Malone, J. M.

1969 Report on the Excavation and Analysis of a Prehistoric Site in Liberty County, Texas: The Price Daniel Site (41 LB 3). M.A. thesis, The University of Texas, Austin.

Mayha11, Mildred

1939 The Indians of Texas: the Atákapa, the Karankawa, the Tonkawa. Ph.D. thesis, The University of Texas, Austin.

McGinty, Jean L.

1978 Site $41 \mathrm{CH} 231$, 01d River Brick Yard. Site Survey Form, Texas Archeological Research Laboratory files, Austin.

McGuff, P. R. and M. M. Ford

1974 Galveston Bay Area, Texas: A Study of Archeological and Historical Resources in Areas Under Investigation for Navigation Improvement. Texas Archeological Survey, Research Report 36.

Mouton, Eugenie

1900 Josephine Joseph. The Editor Publishing Company, Cincinnati. Mullins, Ann

n.d. Dr. James P. Alford, Resident of 01d River Country. Manuscript in files of Chambers County Historical Commission, Anahuac.

National Register of Historic Places

1971 Inventory-Nomination Form. Orcoquisac Historic District. June 1. Nelson, L. H.

1968 Nail Chronology As An Aid to Dating 01d Buildings. American Association for State and Local History Technical Leaflet 48. 
Newcomb, W. W., Jr.

1961 The Indians of Texas. University of Texas Press, Austin. Neyland, Wayne

1960 Wallisville, May 8, in Field Notes Book \#3, Lower Liberty and Chambers County, Dec. 24, 1959 to Feb. 13, 1962. Copy in files of Chambers County Historical Commission, Anahuac.

$01 \operatorname{sen}$, S. J.

1964 Mammal Remains from Archaeological Sites. Part I, Southeastern and Southwestern United States. Papers of the Peabody Museum of Archaeology and Ethnology 56(1).

Osburn, Mary M., ed.

1963 The Atascosita Census of 1826. Texana Magazine 1-4:300-321.

Partlow, Miriam

1974 Liberty, Liberty County and the Atascosito District. Pemberton Press, Austin.

Peña, Juan Antonio de la

1935 Peña's Diary of the Aguayo Expedition, translated by Peter P. Forresta1. Preliminary Studies of the Texas Catholic Historical Society 2(7).

Peterson, R. T.

1960 A Field Guide to the Birds of Texas. Houghton Mifflin Co., Boston. Rader, Jack Douglas

1971 The Spanish Failure at El Orcoquisac. M.A. thesis, The University of Texas at Arlington.

Randa17, Mark E.

1971 Early Marbles. Historical Archaeology 5:102-105.

Ray, Marcia

1974 Collectible Ceramics. Crown Publishers, New York. Raycraft, Don and Carol Raycraft

1975 American Country Pottery. Wallace-Homestead Book Company, Des Moines, Iowa. 
Richner, Jeffrey J. and Joe $\Upsilon$. Bagot, assemblers

1978 A Reconnaissance Survey of the Trinity River Basin. Southern Methodist University. Archaeology Research Program, Research Report 113.

Ring, E. R.

1960 An Evaluation of the Radiocarbon Dates from the Galena Site, Southeastern Texas. Bulletin of the Texas Archeological Society 31.

1963 Opened by Accident. Newsletter of the Houston Archeological Society 10.

Schuetz, Mardith K.

1969 Description of the Artifacts and Ethno-History of the Coahuiltecan Indians. The History and Archeology of Mission San Juan Capistrano, San Antonio, Texas II. State Building Commission Archeological Program, Report 11.

Semenov, S. A.

1964 Prehistoric Technology. Adams and Dart, Bath.

Shafer, Harry J.

1966 An Archeological Survey of Wallisville Reservoir, Chambers County, Texas. Texas Archeological Salvage Project, Survey Report 2.

1968 Archeological Investigations in the San Jacinto River Basin, Montgomery County, Texas. Papers of the Texas Archeological Salvage Project 13.

Shearer, Harriet Huttar

1944 Biographical Sketch of Thomas William Shearer, M.D. (August 25, 1856-May 7, 1925). Arlington, Virginia, October 1944. Manuscript in the files of the Chambers County Historical Commission, Anahuac.

St. George, Eleanor

1948 The Dolls of Yesterday. Bonanza Books, New York.

Suhm, Dee Ann, Alex D. Krieger, and Edward B. Jelks

1954 An Introductory Handbook of Texas Archeology. Bulletin of the Texas Archeological Society 25.

Texas Almanac and State Industrial Guide, 1904

A. H. Belo and Co., Galveston. 
Thompson, Alexandre

1828 Plano de 1a Bahia y Puerto de Galveston. Map in the files of Chambers County Historical Commission, Anahuac.

Tunne11, Curtis D. and Richard Ambler

1967 Archeological Excavations at Presidio San Agustín de Ahumada. State Building Commission Archeological Program, Report 6.

United States Department of the Interior, Office of the Census

1850 The Seventh Census, 1850. Returns of Schedule One, Population.

1860 The Eighth Census, 1860. Returns of Schedule Four, Agriculture.

United States Government Survey

1941 Aerial Survey Photograph CRC-4A-30, scale 4 inches = 1 mile; December 17.

Wa1ley, R.

1955 A Preliminary Report on the Albert George Site in Fort Bend County. Bulletin of the Texas Archeological Society 26:218-234.

wallisville Age

1897 Articles on Tocal events. December 22.

1898 Advertisement. March 30, May 25, Ju1y 27, August 31.

Webb, Wa1ter Prescott

1952 The Handbook of Texas. Two volumes. Texas State Historical Association, Austin.

Wheat, Joe Ben

1953 An Archeological Survey of the Addicks Dam Basin, Southeast Texas. Bureau of American Ethnology. Bulletin 154:143-252.

Williams, Mrs. Floyd, Mr. Douglas Dugat, Sr., Mrs. Norma Rowland

1976 Historical Sketches of Chambers County Pioneers. Chambers County Historical Commission, Anahuac.

Wilson, Rex L.

1966 Tobacco Pipes from Fort Union, N. Mexico. El Palacio 73(1):32-40. 
Woolsey, A. M.

1932 Explorations in Chambers County, 1932. Manuscript on file at the Texas Archeological Research Laboratory, Austin.

Wooten, Dudley G., ed.

1898 A Comprehensive History of Texas, 1685 to 1899. Two volumes. William G. Scarff, Dallas.

Wooten Sisters

1973 Notes of Conversation with Wooten Sisters, Sept. Files of John Middleton, Wallisville.

Work, W. 0 .

1930 Map of the Lost Lake Area, Chambers County. Surveyed October 1924 to February 1925 by W. O. Work, County Surveyor. Revised March 1930.

1945 Map of Wallisville, Chambers County, Texas. Prepared by W. O. Work, County Surveyor. August 20.

Zim, H. S. and H. H. Shoemaker

1956 Fishes. Simon and Schuster, New York.

PUBLIC RECORDS, CHAMBERS AND LIBERTY COUNTIES

Chambers County Commissioners Court Minutes (CCCCM)

Chambers County Deed Records (CCDR)

Chambers County Probate Records (CCPR)

Jefferson County Land Records (JCLR)

Liberty County Tax Records (LCTR)

\section{ARCHIVAL SOURCES}

A11 archival sources are from the Eugene C. Barker History Center, The University of Texas Archives, Austin, unless otherwise noted.

Amarillas, Marques de las

1756 Viceroy's decree concerning establishment of presidio, mission, and civil settlement on lower Trinity River. February 12. 
Amarillas, Marques de las (continued)

1757 Decree ordering removal of presidio and mission to Springs of Santa Rosa. June 19.

Anonymous

1776 Expediente sobre 1a aprehensión que Don Jacinto de Barrios y Jáuregui Governador de los Texas hizo de tres francesses y dos negros que se hallaban establecidos a orilla del rio de la Trinidad, uno de los de aquélla Provincia con intento de atraher gente de su nación para formar una Colonia. October 22. Testimonio número 1 , fol io 110.

Arias, Joseph de

1754 Testimony regarding capture of Blancpain. October 22.

Arriaga, Fray Don Juliano de

1757 Decree of viceroy condemning French to life imprisonment if found illegally in Spanish territory. July 19.

Barrios y Jáuregui, Jacinto

1754a Orders for Marcos Ruiz to reconnaissance lower Trinity and arrest French. September 20.

1754b Urging the viceroy to establish a presidio at the mouth of the Trinity. November 20.

1754c Urging viceroy to estab7ish presidio and mission at the mouth of the Trinity. November 30 .

1755 Orders to Domingo del Rio to reconnaissance lower Trinity River and determine if Lacreu had returned. Apri1 29.

1756a Viceroy informed of progress of presidio and mission. July 12.

1756b Order Miranda to survey lower Trinity River. August 26.

Blancpain, Joseph

1755 Testimony regarding French trade activities along the lower Trinity River. February 19.

Bustamante, Lorenzo

1764 Concerning Pacheco's refusal to surrender. October 10. 
Castañeda, Juan

1818 Diary concerning the search for and destruction of Champ d'Asile. September 16.

Cordova, Cristobal de

1754 Testimony regarding capture of Blancpain. October 22.

1755 Testimony concerning the expedition to mouth of Trinity River. June 5 .

Cordova, Cristobal de, Joachin del Rio, Joseph Antonio del Toro, and Ponzeano Trexo

1764 Reasons for their desertion from San Agustin de Ahumada. August 28.

del Rio, Cristobal

1755 Testimony regarding expedition to mouth of Trinity River. June 4.

del Rio, Domingo

1754 Testimony regarding capture of Blancpain. November 18.

1755 Testimony regarding expedition to mouth of Trinity. June 4.

1756 Testimony regarding lower Trinity River and the Springs of Santa Rosa. August 26.

Marenti, Jose

1766 Inventory to Rivera. Zacatecan Archives, Div. M, Seg. 5, Doc. 62. Boltar Papers, Baucroft Library, Berkeley.

Martos y Navarrete, Don Ange]

1759 Letter to Marquis de las Amarillas, San Agustín de Ahumada. December 6. In Papeles que explican la fundación del Vecindario que se avia de haver heco en el Orcoquiza. M. Num. 93. Mission San José Research Library, San Antonio.

Miranda, Bernardo

1756 Testimony regarding lower Trinity River and Springs of Santa Rosa. August 26.

1757 Testimony concerning Springs of Santa Rosa. April 15. 
Orobio y Bazterra, Joaquin

1745 Investigation of lower Trinity River and Rio Aranzazu reported to viceroy. October 1.

Pacheco, Raphael Martínez

1764a To viceroy concerning his activities on arrival at El Orcoquisac. May 14.

1764b Arrival of Canos. May 31.

1764c Canos request for a mission. June 6 .

Rivera, Melchor Afan de

1766 Testimony regarding arrest of de1 Rio. Apri1 23.

1768 Inventory of the goods which the Mission of Nuestra Señora de la Luz de Orcoquiza has, existing in the royal Presidio of San Agustin de Ahumada . . . Presidio of Orcoquiza. May 25. Mission San José Research Library, San Antonio.

Rubi, Marques de

1768 Report of inspection of El Orcoquisac. April 3.

Ruiz, Marcos

1754 Report to the governor regarding capture of Blancpain. October 14.

1764 Testimony regarding Pacheco's refusal to surrender. October 7.

Ruiz, Marcos, Domingo del Rio, Cristobal de Cordova, Carlos Granda, Juan de Mora, Joseph del Toro, Juan Joseph de Cordova, Ponzeano Trexo, Joachin Mansolo, and Nicolas de Villa Fuerte

1764 Burning of Pacheco's quarters and his escape. October 11.

Salcedo, Nemesio

1805 Regarding establishment of garrison at Atascosito. July 1. Vallejo, Fray Francisco

1758 Concerning Fray Caro's description of miserable conditions at El Orcoquisac. February 27.

Villa Fuerte, Nicolas de

1764 Testimony regarding attempt to arrest Pacheco. October 10. 


\section{APPENDIX I.}

\section{CEDAR BAYOU BRICKYARDS}

Nelson Martin was a pioneer resident of Baytown and remembered the Cedar Bayou brickyards when they were in production. His family urged him to write down his memories, and the following series of articles appeared in the local newspaper soon afterward. 


\title{
BRICKYARDS DOMINATED EARLY ECONOMY HERE
}

\author{
NeTson A. Martin
}

In a11, there were as many as seven brickyards in operation up and down Cedar Bayou at one time. Ed Smith had a yard at Needle Point (near Gulf 0il Corporation's olefin plant). Just downstream from him, on the bayou, was the Rheume brickyard. About where Highway 146 crosses Cedar Bayou was the brickyard operated by Rosemon and Milam (later owned by W. D. Haden).

Ranging downstream from Highway 146 were brickyards operated by Fred Gillette, Will Fayle and Mike Casey. Furtherest downstream -- and just below where Roseland Park stands today -- was the brickyard of Tom Wright.

It didn't take too much capital investment to get into the brick-making business. This was fortunate because it was not much of a moneymaking business, as we shall see.

For example, the first brickyards molded their brick and then dumped them to sun-dry on a smoothed-off place in the yard -- scraped bare and swept clean. This gave the industry its name: brickyard.

But this method soon proved unsatisfactory since the "green" unbaked brick were more or less inclined to dry unevenly in the sun. When they dried too fast, they tended to crack.

Then they began to build drying sheds in which to store the fresh-molded brick out of the sun's heat. This not only allowed a longer drying time but protected the sti11-soft brick from the rain.

A day's work for a six-man molding crew was 5,000. These six workers included four men and two boys.

A day's batch of brick began in the molding pit. This pit -- about 12 feet long by 7 feet wide -- was dug three to four feet down into the earth. It was walled and floored with heavy planking.

First man in the production line was the dirt-carter who hauled the raw material in a two-wheeled cart to the molding pit. Suitable soil might be found within a couple of hundred yards of the brickyard, or it might have to be hauled as much as a mile.

The mixture required two loads of top-soil loam to one load of clay. Most of the clay was found two or three feet down under the top-soil, but Mike Casey would plow up clay in his pasture and shovel the plow-turnings into the dirtcart.

This loam-and-clay mixture was wet down in the molding pit and allowed to soak with water for at least 24 hours. Mike Casey was his own yard foreman and hauled his own water. He had a 50-gallon barrel mounted on sled-runners, which he drove to the bayou bank. There he would use a bucket on a short rope to 
reach down the few feet to the water's surface and to raise the bucketsful of water to dump into the barrel. If the dirt mix was dry it would take ten or more barrels to soak the mud. And his mud was allowed to soak for 24 hours at least.

Baytown Sun, February 12, 1968, page 4

\section{PIONEER RECALLS BAYOU BRICK-MAKING HISTORY}

Nelson A. Martin

A mud mill stood alongside the molding pit. This was a four-foot by four-foot box of heavy planking and stood five feet high. Upon and down through the center ran a revolving king-post projecting almost two feet on every side. As the king-post turned, these teeth mixed the mud as it passed through the mi11.

This was a one-horse-power (or a one-mule-power) mill. A long lever-like sweepboom projected from the king-post and arched over the molding pit. Hitched to the end of this boom, a horse or mule plodded an endless circle around the molding pit and mud mill.

Standing in the mud, the pit-shoveler threw the loam-clay mixture into the top of the mud mi11. As the horse, through long habit, circled his hoof-grooved path without direction, the teeth mounted in the grinding king-post cut through the mud to cut and mix it thoroughly.

A slot cut in the bottom of the mud-mi11 wall let the mixed mud out when it was ready to be worked into brick. A hinged board served as a door to open or close the outlet from the mud-mi11, thus regulating the output. The longer the mud remained in the mi11, the more moisture was ground out of it and the drier the mixture became.

The mud-wheeler moved the mixed mud, by wheel-barrow, from the mud-mill to the brick molding table. If the horse on the mud-mill lagged, the wheeler threw a clod or a stick to make him move faster.

The molder, considered the head man in the molding crew, stood at the molding table and hand-molded the mud into a three-brick wooden mold. Standing directly across the molding table from the spot where the mud-wheeler dumped the mixed mud, the molder made a circle of his arms until his finger-tips touched. Then he would slice his hands down across the edge of the mud pile and cut off a pone of mud just the right size to mold into a brick.

(Long experience let him cut off pones with great accuracy. This constant working in mud seemed to have no $i 11$ effects on the molder's hands. However, he would occasionally bruise or cut his hand on a stone or stick embedded in the mud.) 
As he drew the pone toward him, the molder turned it three times on the table covered with sifted sand. Thus "floured" with sand, the damp brick could be handled easily without sticking. Finally, he raised the pone and plopped it into one of the three cells in the three-brick mold, using enough force to fill all corners of the mold with mud. He finished by spanking it into place.

Twice more he repeated this process to fill the three-brick mold, which had been well sanded so that the brick would not stick to the sides or bottom of the mold.

Finally he would take a striking stick -- a 16-inch stick about an inch and a half wide and made out of quarter-inch material -- which he would drag across the mold to finish it off with a smooth surface, ready to be dumped on a board for storing in the drying shed.

Baytown Sun, February 13, 1968, page 4

HOW BRICKS WERE MADE ALONG CEDAR BAYOU

Nelson A. Martin

The crew kept two of these three brick molds busy. While one was being filled, the molded brick were being dumped from the other.

Both boys in the crew were called off-bearers. They did two different jobs and they changed every 500 or every 1,000 brick.

One boy picked up a three-brick mold as soon as the molder had filled it with mud and then dumped these three brick on a three-quarter-inch board about four inches wide and three feet long. (The mold was a long slot with two partitions dividing it into compartments for three bricks, end-to-end.)

The other boy carried the board with the three brick into the drying shed. The open shed was a frame-work of vertical eight-inch wooden posts buried at least three or three and a half feet in the ground. Horizontal strips -- one inch by two-inch lumber -- were nailed from post to post. The ends of the brick-bearing boards were rested on these strips which were spaced just far enough apart to allow room for the brick.

A rough-batten roof of one-inch by 12-inch lumber kept out the rain and prevented direct sunlight from drying the brick too fast.

The boy would bring back empty boards from the shed -- board from which al readydried brick had been removed -- to the off-bearers' table where they were stacked within easy reach of the other off-bearer who was emptying the molds. As soon as this off-bearer emptied one of the molds onto a board at the off-bearers' table, he would sand the mold and hand it back to the molder.

The molding crew also included two brick-wheelers who moved the brick in wheelbarrows from the drying shed to the brick kiln. These brick would have been in 
the drying shed for three or four weeks, depending on how long it took to get ready to burn another batch in the kiln.

Wheelers used two-inch by twelve-inch (or one-inch by twelve-inch) boards to make a gangway for their wheel-barrows as they delivered brick to the kiln.

The brick-setter worked in the kiln and was probably the highest-paid man in the crew. He might earn $\$ 1.25$ a-day while molders got from $\$ 1$ to $\$ 1.25$.

A kiln would hold about 300,000 brick and there would be another kiln to burn about every six weeks. These kilns were built of green or unburned brick. The first time the kilns were fired, these wal1-brick were burned hard on the inside and heat-dried on the outside surfaces so that they took weather pretty good.

They used three-eyed and four-eyed kilns. These eyes were arch-shaped opening extending from ground level up for about four feet in the brick walls. As the brick-setter stacked dried brick inside the kiln in preparation for firing, he arched his brick so that these eyes extended all the way through the kiln. A one-brick- wide partition across the middle of the kiln cut across these eyes but this partition was usually punched out in the process of firing.

It took about 150 cords of wood to fire a kiln. When a kiln was ready to fire, the molding crew stopped molding brick and worked -- three men on each side of the kiln -- on the firing.

At the first day of the firing, just a small fire was built in the opening of the eye -- a bit of blaze in each eye. Gradually the amount of fire was increased.

By the fifth day -- and from then until the eighth day -- the fire was kept as hot as possible around the clock. Four-foot sticks of pine cord-wood was shoved into the eyes as fast as it would burn. Long green-wood poles were used to push these burning logs as far into the kiln as possible, finally punching out the interior brick partition.

Intensity of the accumulated heat can hardly be described. Flames would sear up through layer upon layer of brick and flicker across the tops of the bricks in the kiln.

Baytown Sun, February 14, 1968, page 6

\section{5,000 BRICKS BROUGHT ONLY \$30 AT GALVESTON \\ Nelson A. Martin}

On the eighth day the eyes of the kiln would be filled in with dried brick to complete the wal1. Then these eyes would be mudded over. Buckets of loose dirt would be passed up to the brick-setter who, standing with one foot on a 
ladder and the other on the edge of the kiln, threw this dirt across the hot bricks until they were covered two or three inches deep -- thus holding in the heat. As soon as the kiln grew cool enough, a roof of rough-batten one-bytwelve boards would be fitted in place to keep out the rain.

It would take about ten days for the kiln to cool enough to open up and let the brick be moved. Actually, the brick remained in the kiln until a boat could come up the bayou to ship the brick to Galveston or to Houston.

A11 the yards except Gillette's and Casey's owned their own boats. Rosemond and Milam owned a three-masted schooner. The rest were two-masted schooners. Casey and Gillette operated during the latter years when tow-boats could be used to barge brick out of Cedar Bayou.

Since most of the brickyards were located some three to ten water-miles from the mouth of the bayou in Galveston Bay, it was a problem to move sailboats up and down the relatively narrow bayou.

Rosemond and Milam developed an interesting procedure for moving their boats down this twisting bayou to the open bay.

They beat down a tow-path along the east bank of the bayou on the Chambers County side -- across the stream from Harris County. (They were the biggest operators on the bayou, supposedly operating three or four molding crews and owning their own boats.)

Their towing operation was powered by a horse or mule ridden by a small boy. He did not, as one might suppose, have a harness on the animal with the towrope hitched to the singletree for pulling power. Instead, the tow-rope ran from the pommel of a saddle upward to where it was tied high on the mast of the boat being towed. This kept the rope free from tangling in the brush and shrubbery between the tow-path and the water's edge.

Posts and braces still stand, half-rotten, to mark the footbridges used by horse and rider to cross the tributary gullies which flowed into the bayou.

This tow-path permitted regular trips up and down the bayou by sailboats regardless of the wind.

When a boat was on hand to be loaded, even the molding crew would sometime take off from molding to help wheel the burned brick onto the boat.

Ordinarily a crew could get to work by good daylight and finish work before noon because a day's work for a molding crew was 5,000 brick.

These boats hauled 50,000 to 100,000 brick. They had very roomy holds, as the below-deck cargo space was called. Then as many bricks as possible -- often more than were in the hold -- were stacked and stored on the open deck.

Brickyard owners never did get rich for there was not the profit in brickmaking that there was in the lumber and saw-mill business. 
In those days brick sold for only about $\$ 6$ a thousand delivered in Galveston. The 5,000 brick produced by a molding crew -- four men and two boys -- thus sold for $\$ 30$ on the Galveston wharves.

Out of this income, brickyard owners had to pay the molding crew and maintain the brickyard -- which was not very expensive -- and buy wood for the kilns. In addition, they had to own boats or pay the cost of shipping the brick to Galveston or -- later -- to Houston.

Baytown Sun, February 15, 1968, page 4

NO ECONOMIC PROBLEMS ON A DOLLAR PER DAY

NeTson A. Martin

When I was a smal1 boy, off-bearing at Mike Casey's yard, we boys got 60 cents a day while most of the men got a dollar. It is surprising how well families got along. There was no unemployment or economic problems and no starving children in those days.

Of course, after a man finished his day's work at the brickyard about noon, he still had half a day in which to grow food for his family and feed for his livestock. Most men raised enough food and feed that they had to spend little at the local stores.

Irish and sweet potatoes were grown and could be stored for almost year-round use. Most meat was home-grown.

But at either side of the two stores -- Ilfrey's or Ellisor's -- a family could buy a side of bacon for $\$ 1.50$. A 48-pound sack of Tidal Wave flour, milled in Galveston, cost 75 cents. A pair of dress shoes sold for $\$ 1.50$ to $\$ 2$ and heavy brogans for working sold for $\$ 1$ to $\$ 1.25$. A quarter would buy a big bag of navy beans.

Brickyards did not operate in the winter months because the bricks would freeze and break while they were still wet. (Otherwise, weather did not pose too much of a problem except that a hard rain during the day would often cost a day's work since there would be too much water in the unroofed molding pit.)

On just ordinarily damp days we used to dry our sand by building an open fire and scattering sand across it so that, after it burned out, we could scoop up the dry sand and ashes in wheel-barrows to use on the molding table.

But the brickyards provided winter-time employment even though no bricks were being molded. It took a lot of wood to burn the brick and everyone who wanted to work could go to the woods and make almost as much cutting cord-wood in cold weather as they could make in a molding crew during warmer weather. 
Cutting wood meant a longer day's work, but there was less gardening and farming to be done in the winter time. And this off-season employment did tide families over through the winter season.

For more than half a century, this brick-making industry was the economic backbone of the Cedar Bayou community from which Baytown later developed.

I do not know where to find information about the beginning of brick-making on Cedar Bayou. But I would judge that it started between 1850 and 1865 . Allen Wright told me that his grandfather, Tom Wright, came to Cedar Bayou in 1871 as an immigrant from England and that the brickyards had been operating for several years by that time.

Tom Wright bought out the yard which had been operated by Col. Ashbel Smith who sold it because it seemed to be a money-losing operation. So evidently, brick-making had been under way along Cedar Bayou for some years prior to 1871.

In addition to serving as the basis for the economy of the Cedar Bayou community, brickmaking contributed importantly to the building of Galveston and then Houston. Unfortunately, our Cedar Bayou brick cannot today be identified in the landmark structures of those cities since it was not the practice in the early days to stamp trade-marks into bricks.

I remember being in Houston as a smal1 lad and seeing workers build a street of brick. They first graded the street surface to the grade-level desired and then laid one-inch by twelve-inch creosoted boards as a rough floor. Then they stood brick on edge, as close together as possible and without any mortar between them. This made a very good street.

It provided a smooth surface and kept out the mud. Of course, it was a little noisy with the old iron-shod horses and steel-rimmed wheel of the horse-drawn vehicles in those days.

Brickyards operated along Cedar Bayou until the discovery of oil -- after the turn of the century -- brought in the much higher wages paid to workers in oil production and later in oil refining.

Thus came to an end a little-known but very significant industry which was -except for some farming and livestock -- the sole support of the Cedar Bayou community of Texas pioneers who were the forebears of many Baytown families.

Baytown Sun, February 16, 1968 
APPENDIX II.

ARTIFACTS FROM WILSON BOARDING HOUSE TEST PIT 
Personal Articles

7 clothing hook fasteners clothing snap fastener fastener tab: "TRUEFIT" filigree metal belt buckle gilded watchband buckle

2 small buckle fragments

8 shoelace eyes eyeglass lens metal cufflink, glass set

8 shel1 buttons

4 white glass buttons orange glass button bone button fragment

3 purse frame fragments

2 metal tear-shaped objects brass latch part

brass hinge

3 brass tacks threaded brass knob spring spring, 5/8" in diameter clock gear folding ruler hinge

4 clay marbles fragment cut celluloid (guitar pick?)

3 slate fragments slate pencil fragment

10 porcelain doll fragments porcelain doll teapot fragment

2 porcelain doll dish fragments

\section{Kitchen and Dining Articles*}

clear whole bottle:

"CHEESEBROUGH MFG. CO/VASELINE

2 clear whole bottles

483 clear glass containers

3 clear glass drinking containers whole aqua glass panel bottle:

"DR. S. PITCHER'S CASTORIA"

103 aqua glass containers (mostly canning jars)

38 brown glass containers

11 blue glass containers

12 emerald green glass containers

11 blue glass containers lavender glass pitcher handle

28 lamp chimney/light bulb

21 pressed glass glass stopper cream-colored glass mug

7 pink-cased glass green and white cased glass

7 white and clear cased glass

5 milk glass

5 white glass jar lid liners blue she11-edged earthenware

9 gold-decorated earthenware

2 silver luster decorated earthenware

12 decalcomania-decorated earthenware

24 plain white earthenware

136 ironstone, including "J. \& G. MEAKIN" and "JOHNSON BROS."

2 ironstone with green-painted design ironstone with blue transfer design porcelain (cup handle)

8 plain white porcelain

9 decalcomania-decorated porcelain

4 gold-decorated porcelain

7 painted oriental porcelain Tuster on stoneware stoneware bottle fragment

metal pot handle

* Fragments except where otherwise noted. 


\section{Building Materials}

220 cut nails and fragments

242 wire nails and fragments

367 unidentifiable nail fragments

8 square spikes

2 tacks

6 fence staples screw hook screw eye

4 washers

2 door hinges corrugated fastener pipe flange plated metal window shade bracket

10 wire fragments

2 lead sprue fragments early light bulb base

6 electrical fixtures fragments

47 brick fragments

174 window glass fragments

Miscellaneous

electrical fuse valve cap

3 shotgun shells:

"UMC Co./No.12/NEW CLUB" (2)

"WINCHESTER/No.12/NUBLACK" (1) beveled flashlight lens

$10 \mathrm{oz}$. coal

32 oz. clam and oyster shell

28 oz. unidentifiable metal scrap

7 fragments peach pits 
APPENDIX III.

"INVENTORY OF THE GOODS WHICH THE MISSION OF NUESTRA SEÑORA DE LA LUZ HAS, EXISTING IN THE ROYAL PRESIDIO OF SAN AGUSTÍN DE AHUMADA . . ."

$$
\begin{gathered}
\text { Melchor Afan de Rivera } \\
\text { Presidio of Orcoquiza } \\
\text { Sept. } 12,1766
\end{gathered}
$$

Translation by Dora Guerra 
Inventory of Orcoquisac Mission

\section{7}

$$
\frac{M}{N . \quad .62}
$$

Inventory of church, house, and field goods belonging to Mission Our Lady of Light in the Orcoquisac (territory) turned over to me in January 1767, and (1ist of) improvements from said year to the present day of 24 May 1768, which I, Father Manuel Maria de Senor San Jose Marentis minister of said Mission turn over to the soldier Manuel de Acosta by order of Rev. Father Miguel de Santa Maria. The items are...

Church. There was no church in existence. Goods which I received, and turned over.

First 1 Canvas painting of Our Lady of Light

1 Canvas painting of Christ before Pilot

1 St. Peter Alcantara. I was able to find only the burlap, and that is how I turned it over.

9 Little drawings on paper

1 Sma11 canvas picture

1 Metal cross

1 Tin lamp

2 Brass candleholders

1 (Statue) of St. Esleta which Fr. Silba burned because it was in such a poor state.

1 (Statue) of St. Francis Xavier with a silver crown and heart.

1 Embroidered banner

1 Copper baptismal font filled with holy water, plus a silver conch for pouring.

1 Copper, holy water container.

1 Altar table.

3 Black sheepskins.

1 Red lectern.

1 Confessional. 
1 Altar platform. It is listed in Fr. Salbino's (inventory?). It was not turned over to me, nor did I carpet it.

1 Box of (church) ornaments.

1 Alb. 3 amices. 1 surplice and (1 word unknown).

1 Smal1 chest with 21 purificators.

1 Small chalice spoon. It was lost.

1 Paten and 1 white cape.

1 White humeral veil and 1 white ( 1 w. unkn.).

1 Goldplate over silver reliquary.

1 Ciborium cover and (2 words illegible) cloth.

1 Red (1 w. i11.).

$1 / 3$

A few silk and gold cords.

4 Altar cloths in red, purple, green, and black with their corresponding capes.

2 Cross covers. One black, one white.

3 Small silver bottles.

2 Boxes of vials.

1 Mold for making hosts.

2 Undamaged bells.

2 Bronze crosses. One is a crucifix.

1 Badly damaged silk cloth.

1 Piece of a tunic.

3 Pieces of satin. I have turned over only two.

Improvements to the church during my administration, and which I now turn over.

First 1 church. Eleven to twe lve varas long and about seven varas wide with a nailed down shingle roof. It is whitewashed, and has an adequate sacristy, also 
with a shingle roof. Its chancel is on a platform with railings and the choir has a floor and railings. (There is) a pulpit, confessional, and baptistry. Its entrance is around two or four varas wide. It has a cemetery, thirty varas long and sixteen wide surrounded by handrails.

1 Silver chalice about a cuarta (measure) tall, and four which measure about two cuartas.

1 Chalice, two patens, and two 1ittle spoons.

1 White vestment.

2 Missals and one Saints-day manual.

1 Pair of pulpit cloths.

2 Altar cloths one of which had been turned over to me, and which had not been listed in the inventory.

2 Communion rait cloths.

6 (2 w. i11.) (Chambray) that is Brittany cloth.

3 Altar cloths, one of which I cannot find but which I did turn in. It is probably misplaced.

4 Canvas paintings. One of the Trinity; another of Christ, another of Our Lady of Sorrows and another one of St. Anthony.

7 Sma11 drawings on paper.

8 Holy pictures.

1 ( 1 w. unkn.) and one bronze censer, with its spoon.

Next page

$1 / 4$

2 Large, wood, gold-leafed candle holders.

1 Bronze one of the same date.

4 Glass (1 w. unkn.).

8 Glass ( 1 w. unkn.).

6 Bottles.

1 Tabernacle covered in satin with its satin curtains.

1 Altar. 
1 Altar carpet. Two mats, three wooden platforms in the sacristy. An altar and a confessional.

2 Drapes on the two doors of the sacristy.

1 Small altar bell. Two glass vinegar containers and their glass plate.

1 Tin Host box.

10 Varas of ribbon for Our Lady.

2 Glass Glasses.

9 Corporals which had not been listed, and twelve coins, and 2 rings.

Some bracelets.

1 Small container for the salt of the baptistry.

1 Sma11 cup with salt and holy water.

9 Sma11 cups.

1 Small bench in the sacristy used in the holy service.

1 Small hand lavatory stand used as a table in the chancel.

1 Throne for Our Lady.

1 Missal borrowed from Fr. (2 letters illegibile)nellano and, a chalice from the mission at Los Adaes.

1 Thick flannel table cloth for the sacristy, and one bench for daily use, also some curtains that had not been listed before.

1 Vara of tissue-like ribbon for the tabernacle.

1 Armchair for daily use.

1 White cape.

\section{Books I received and turned over}

3 Volumes of Martimas (?) de Garau.

2 Vols. of meditations by the same author.

Leaves from The Tree of Life.

Works of Zabaleta.

Larraza (author?). 
Sermons

1 Book of sermons

Father Corella

Next page

$/ / 5$

Father Montenegro.

Second and third parts of The Mystic City of God.

3 Vols. of Barcia and another one I found later.

The Damages of Lechery.

Father Castro.

3 (1 w. i11.) Christian, one of them red.

Father Fulgencio Lafore.

Finosinum theolojicum.

1 Book of eulogistic sermons.

2 Catechisms, one of the present.

2 Quivers (for arrows), one of them is missing.

1 Seven day missal.

1 Manua 1.

Claudiano.

7 Vols. of Boyvin's Philosophy and Theology.

7 Breveries in four parts.

Another one which I found, and had forgotten.

2 Vols. of Afolis de la Muza.

Holy Week homilies not included (in prior list?)

House. There was none. Following are the household goods which I received and now turn over.

2 Shelving units and a wardrobe.

2 Beds and two canopies. 
2 Benches, large and small.

1 Armchair and three armless chairs.

2 Copper holy water containers one has a lid and key. The other one is without a lid and contains the Baptismal water.

1 Cabinet with eight glasses some of them crystal.

1 Large iron and a pair of tailors scissors.

1 Box with its lock and key.

2 Platters.

10 Small glasses and several tablecloths.

1 Spoon and two forks.

1 Large damask.

1 Chamber pot.

2 Candlesticks and two broken snuffers.

$1 / 6$

Kitchen. There was none. Goods which I received and turn over.

2 Iron stokers.

2 Ladles.

3 Tri-legged pots.

2 Copper ones (pots).

2 Skillets.

1 Mortar with handle.

1 Heater.

1 Sma 11 caldron.

3 Grinding stones, one is without a handle.

1 Iron grill.

Mission miscellanea which I received and now turn over.

4 Hoes.

2 Augers. 
2 Saws.

4 Plowshares and one pointer.

2 Hammers.

3 Machetes.

1 Brush and one plane.

2 Smal1 plots of 7 and.

9 Chisels and two (1 w. unkn.).

1 Hatchet.

2 Locks and keys.

1 Round file.

1 Branding iron.

2 Pear trees from the Coast, but which I am turning over here.

2 Bars and a tong.

Improvements to the Mission, etc. [sic.]

First A house measuring 23 varas in length. It has a livingroom, two cells, an awning, a balustrade and an arched entry. It has six doors which lead to the street and two that lead to the inside. Four of the doors have locks and keys. The house is whitewashed, and has a nailed down shingle roof.

$1 / 7$

A kitchen with its chimney 92 varas long. It has a door, and a room used as an office. There is an awning, a door and key. There are the necessities with doors.

1 Chicken coop.

1 Oven.

A garden fence against the house with its gate and lock.

A Stockyard and a pig pen.

An iron kettle.

A copper kettle.

A pot, a skillet, and an iron grill.

3 Glasses, one sma11 and two medium ones. 
6 Cups from Puebla.

7 Bowls and six plates from Puebla.

2 French plates.

2 Salt shakers, a tin one and a wooden one.

2 Pewter plates.

3 Napkins.

12 (1 w. unkn.).

1 French, white jar, and another medium one.

1 (1 w. unkn.).

1 Tray (1 w. unkn.).

2 Clay jugs one contains some lard.

4 (1 w. unkn.).

1 Large and one small tables. The large one has a tablecloth of cotton.

8 Harnesses, riding gear, horse blankets, and ropes.

Fr. Santa Maria has one of the harnesses.

Four others are at the Sabine creek, left there by (2 w. ill.) and covered with a blanket. Don Gaspar Christen left a harness and riding gear at the Mission at Los Adaes.

4 Sets of riding gear are in very bad shape.

1 English rifle. The key (lock?) was taken to be repaired by Nicolas. $1 / 8$

2 Augers. One large and one small.

1 Large stone cutting chisel.

2 Broken hatchets.

4 Pieces of steel.

1 Lock for which the key could not be found at the time of the inventory. Key has been found.

1 Gun barrel and key.

2 Wooden stools. 
4 Boxes. One small and 3 large.

1 Pound of white, loose, string.

Some sugar cane.

1 Large box filled with ( 1 w. unkn.) for locks.

1 Pack of 30 packets of tobacco.

3 Bamboo mats.

1 Book of Indian funerals and baptisms.

1 Said book of Spanish funerals and baptisms, both bound in ( 1 w. unkn.).

1 Said book of marriages.

1 Crate of soap with a thousand bars. Also Julia. (The word Julia here seems to be used in reference to wrapping material. It is consistently used in that context, but I could not verify this, other than that each time it is used it is used along with other words that signify wrapping materials.)

2 Spoons. One is metal, the other is tin.

18 Pounds of wax from the North, made into 94 candles already blessed.

1 Lead ink well with its sandbox.

1 Smal1 host box.

1 Box with 700 bars of chocolate with its corresponding wrapping materials, and ropes.

1 Counter with its respective booth.

1 New hatchet.

2 Horse blinders and a ( 1 w. unkn.).

4 Weeding hoes and shovels.

3 Latches without ( 1 w. unkn.).

1 Knife holder with 9 knives.

A few new ( 1 w. unkn.).

2 Small crystal jars and a large one.

1 Small dinner plate and knife. 
1 Brazier.

2 Sheets, one is Brittany cloth, the other is cotton, and is torn. 2-1/4 varas of striped, coarse cotton.

$1 / 9$

7-1/2 varas of cloth from Querétaro.

3 varas minus 2 fingers breadth of flannel.

1 Coarse cotton cloth from Villalta and a Patio (?).

1 Handful of black beads.

3 Sheets of sieve cloth, and one sieve.

1 Striped shawl.

11 Varas of Chinese linen.

6 Field blankets.

93 Smal1 paper notebooks.

6 Hand breadths of cut paper.

2 Jars of ink.

4-1/2 Pounds of cotton spun for wicks.

9 (1 w. i11.) 2 (1 w. i11.) of saffron.

2 (1 w. i11.) of black pepper.

9 Packets of anise, coriander, rosemary, cumin, and (1 w. unkn.).

1 Metal spoon.

90 Pieces of (molded) brown sugar in a crate with its corresponding wrappings and Jutia.

10 Pairs of leather shoes.

5 ( 1 w. unkn.) 9 pounds in a sack of un-milled flour.

There is a half-filled keg of wine.

12 Skeins of white silk.

1 Fifty-nine $1 b$. crate of suet with its corresponding wrappings and ropes. 
37 Skeins of cotton thread.

13 Skeins of blue century plant thread.

26 Skeins of blue silk.

4 Arrobas plus 6 lbs. of salt with its corresponding sacks, wrappings, and rope.

3 Packets of straight pins.

1 (1 w. i11.) of hemp for rope.

17 lbs. of nails for shingles.

1 Grain measure of garbanzo beans, and 6 lbs. of rice.

Plus 1 iron fork.

2 Jars of $0 i 1$.

$/ / 10$

1 Gourd bowl filled with ground chilies.

$6-1 / 2$ bushels of corn.

1 Jug.

9 Sacks of packing and wrapping materials, and 1 (sack of) burlap (wrapping).

891 Ears of yellow corn.

Another sack of burlap.

4 Loose guangoches (wrapping material).

2 Loose crates.

2 Bed boards.

I Small vial of ointment.

1 Pocket watch with a broken stem.

2 Plows.

12 (1 w. i11.) of fish.

4 Steer horns. One sma11 sack of chilipitin peppers.

1 Candy Box. Found the lost key to the lock above mentioned. 
1 ( 1 w. unkn.) and a handleless knife.

1 Mirror. One dinner fork.

1 Valuable spoon.

7 Chickens, 1 rooster, and 6 chicks.

Field goods which I received and now turn over.

Mares

2 Dapple-grays

2 Roans. One of these is being claimed by (1 w. ill.) Josephine Sensuya. I have not given it up because of insufficient proof (of ownership). Plus (the mare) has the Mission's brand ( 1 w. unkn.).

1 Honey-colored (mare).

$/ / 11$

I Black mare

1 Red, which I exchanged.

1 Roan. This one died. Everyone is aware of it.

1 (4 w. i11.) which I exchanged.

1 Roan from the Valdez stock. I received and now turn over with two foals, but she is embargoed because Miguel Ramos claims she belongs to him.

A11 the rest 7 isted in the inventory turned over to me at the beginning of my administration, which were not really accounted for, I do not claim to have received.

Another black mare from the Valdez stock which I received, I now turn over. A11 in a11 I have turned over seven mares.

Fillies received and turned over.

4 Fillies. One ( 1 w. unkn.) Dapple-gray, one roan, one red, one dapple (1 w. il1.).

4 Colts born after Rev. Fr. Salbino departed.

1 Dapple horse.

Mules received and turned over.

1 Bay coyote, which I am turning over. 
1 Male Pilatos (Tribe?) which I turn over.

1 Black male which I received, but which was left in Nacogdoches by one of my braves because the mule was too tired to travel.

1 Bay mule. I lost her at Las Cruces.

Her name is Pollita.

1 Roan colored young mule which I sold. That is why I have only two missing ones and two present ones to turn over.

Steers which I received and I am now turning over.

I received six oxen. At my departure for La Bahia I turned over nine. When I returned I received two, one of which was dying. I now turn over two in good health. Of the remaining steers reflected in the inventory turned over to me, they were never accounted for; because some had strayed and other had died. I noted that in that particular inventory.

$/ / 12$

Summary of these goods turned over.

Mares accounted for $\quad 11$

Oxen 02

Stud horse 01

Mules accounted for 02

\section{Missing Goods}

1 Two-year old dapple mare with her foal.

1 Two-year old roan and her foal.

1 Smal1 roan. Two (3 w. i11.).

Mutes and Males Missing

1 Black male left in Nacogdoches by one of my men because it was too tired to travel.

1 Bay mule named Pollita in Las Cruces.

$$
\text { Missing Oxen }
$$

1 Black mouthed ox strayed to Calzones. 
Summary of Missing Goods

3 Mares

03

Fillies

02

Mule and male

02

oxen

01

Tota1

(Blank) sic.

14 Mares

14

Colts and fillies

06

Mule and males

04

oxen

03

Stud horse

01

Head

28

Improvements under my administration which I now turn over.

Mares ready for mating whose colors I have already listed in the Mission's cattle notebook 19

$/ / 13$

Colts and fillies present

02

Missing already mentioned

02

Foals present

08

Stud donkey. Black. present

01

Horses turned over and accounted for.

A roan

A (1 w. unkn.)

A black one.

A red one.

A (1 w. unkn.). 


\section{Missing Horses}

One bay

One ( 1 w. unkn.).

One Dapple

One roan

One (1 w. unkn.).
These three were left behind by my braves from San Jacinto.

I said already from the San Jacinto brand.

\section{Mules Accounted for and Turned Over}

1 Red mule.

1 Dapple with Fr. Roque's brand.

Another red mule.

One chestnut colored male with Fr. Francisco's brand.

Another chestnut colored mule.

Another " "

One dapple mule.

Another one.

One black mule named Lachinpas.

One chestnut colored male.

Another bay, male.

$/ / 14$

Mule Foals Accounted For and Turned Over

1 Young female dapple.

1 Young black male.

1 Young red male.

\section{Missing Mules and Males}

1 Black mule for mounting.

1 Black male.

1 Chestnut-colored male with broad forehead.
These three stayed on this side of the Guadalupe. They have the brand of the Provincial Captain.

1 01d, ash-colored male which I left behind at La Bahia. Plus one chestnut-colored male which at the time of my departure strayed. 
Cows Accounted For and Turned Over

7 Cows

1 One-year old bult.

1 Male calf.

1 Female calf.

Summary of Above Enhancement to the Stock

Mares ready for mating and accounted for $\quad 19$

Young colts and fillies 09

Missing 02

Foals not missing 08

Black stud donkey not missing 01

Horses not missing 06

Horses missing 09

Mules and males not missing (Blank) sic.

Cows not missing 07

1 One-year old bull 01

2 Sucklings, a male and a female $\quad 02$

Total addition to the Stock 75

//15 General Total of Present and Missing Goods Received And Turned Over. Including the Enhancement To The Stock

Received 28

Increased 75

103 Head

NOTES

I am in debt to no one. Nor have I loaned anything to anyone. Of the Mission's debts, as reflected in the Mission's ledger, left behind by Fr. Salvino, I have paid for three cows, including their calves, as shown in the ledger. (The Mission) owed ( 1 w. unkn.). I paid Capt. Melchor Afan for them, or better still he, himself, paid himself as is reflected in the ledger, but (the ledger) is in error with respect to what is owed this Captain. 
Also I have paid for four pounds of nails which the ledger shows we owe the soldiers. I have already paid them.

With regards to these two other transactions reflected in said ledger stating that to Moises Laforma fifty four pesos are owed; I have not paid them by order of my Superior. I sent (1 w. i11.) Fr. ( 1 w. i11.) that did not happen to me (??? meaning is confused). As for the other transaction of twelve pesos to Dn. Manuel de Soto. Said gentleman has not returned to be paid, nor is it known where he might have gone, since he is a fugitive. (The transactions with the French, are the ones I have orders to send to Father). sic.

I declare that besides these transactions which keep appearing in the ledger time and again, there came Don Ramon asking to be paid for three cows, for which I have not paid due to the absence of papers from said Father ( 1 w. i11.) to verify (ownership).

I declared that from Fr. Salbino's administration nothing more is owed.

$/ / 16$

Debts Owed This Mission

This Presidio's Captain, Don Melchor Afan, (owes) two-hundred pesos (1 w. i11.) for my masses and sermons as is evident from a draft which he left for one-hundred pesos 200

4-1/2 Bushels of corn, and six brown sugar cones

2 Pairs of leather shoes

Also the (military) Company owes five and one-half (bushels) of corn, which I agreed to return in species.

Manue] Mendez (owes) 2-1/2 varas of cotton and 1-1/2 of 1 inen.

1 Grain measure of corn.

Lt. Cordoba, 2 grain measures of corn.

Marcos Losoya 1 grain measure.

Chavez another and ( 1 w. unkn.).

Lascano 1 grain measure as above.

Sargeant Ramos 1 horse which he brought from La Bahia lent to him by Fr. Lopez.

Bernabe del Rio 1 horse for the price of a mule.

Josephine owes 19 reales, with the agreement that she is to pay back in milk and cheese. Also she owes $1 / 2$ a vara of cotton and three fourths of linen. I have deducted 5 reales for milk she has already brought. 
I turn over to the said Manuel de Acosta the power to collect 4 mules owed to me by Lt. Josephine.

Another power given to me by Eustaquio for collecting 30 head of horses owed by Mosiva Carlos. Of these I received only 5 mares, which he (Carlos) had already paid (Eustaquio). Of these (five), one did not belong to him. It belonged to Aunt Rosa to whom I returned it. He (Eustaquio?) had sold me a missing colt which he claimed was at the ranch. I paid for it, and never received it.

Even though I have a burro from that stock, I paid for it in reales. (half a line is blank)

In Maria de Chiber's stock, I declared that two mares with the Mission's plain brand, one of which is a bay and the other a black pinto, are hers,

\section{$/ / 17$}

as well as a colt among those listed. Of those ( 1 w. i11.). I gave my part to Juan Domingo in return for his help in gathering my belongings (2 w. unkn.).

Also I declare that at the time of my departure, one of my mules which I was taking $(1 \mathrm{w} . \mathrm{ill}$.$) , and so I took one of the ones listed in the$ ledger.

A11 the things referred to in these eight pages I have turned over to Joseph Manuel de Acosta in the presence of Lt. Christobal de Cordoba and Don Francisco Portilla. To verify its authenticity I signed it on 25 May 1768.

\section{Fr. Manuel Maria de San Joseph Marentis Rubric}

I received from the Reverend Father Manue 1 Maria Marentis everything stated in these eight pages to my satisfaction. All of which will be turned over to whichever Fr. Minister may come ( $1 \mathrm{w}$. i11.) on behalf of the Mission that I might be ordered to carry out. To verify, I signed a cross, since I do not know how to write. I requested Don Christobal de Cordoba to write my name for me. I, Francisco de la Portilla having helped the aforementioned Fr. Marentis with this inventory (do hereby sign).

Christobal de Cordoba Rubric

$$
\text { Orcoquisac, } 25 \text { May } 1768
$$

+ Francisco de la Portilla Rubric

I declare that all the above is true. I declare that the Rev. Fr. Manuel Maria Marentis did in truth turn over to the soldier from my company Joseph Manuel de Acosta, to Acosta's satisfaction, a11 the things Tisted in this inventory, with 
the understanding that Acosta is to turn things over to whichever Rev. Minister comes.

Presidio Orcoquisac

$$
\begin{gathered}
\text { Melchor Afan de Ribera } \\
\text { Rubric }
\end{gathered}
$$

\section{$/ / 18$}

This was faithfully copied from the original which can be found in the Mission. To verify, I signed it on the very same day, 25 May 1768.

I signed with a cross because I am illiterate, and Don Christobal de Cordoba signed for me, at my request. Portilla.

Christobal de Cordoba Rubric

Vo. Bo.

Afan de Ribera Rubric
+ Francisco Portilla Rubric 